\title{
REATOR COMBINADO ANAERÓBIO-AERÓBIO DE LEITO FIXO PARA REMOÇÃO DE MATÉRIA ORGÂNICA E NITROGÊNIO DE ÁGUA RESIDUÁRIA DE INDÚSTRIA PRODUTORA DE LISINA
}

Moacir Messias de Araújo Jr.

Tese apresentada à Escola de Engenharia de São Carlos da Universidade de São Paulo, como parte dos requisitos para obtenção do título de Doutor em Engenharia Civil: Área Hidráulica e Saneamento

Orientador: Prof. Dr. Marcelo Zaiat

São Carlos, SP 2006 


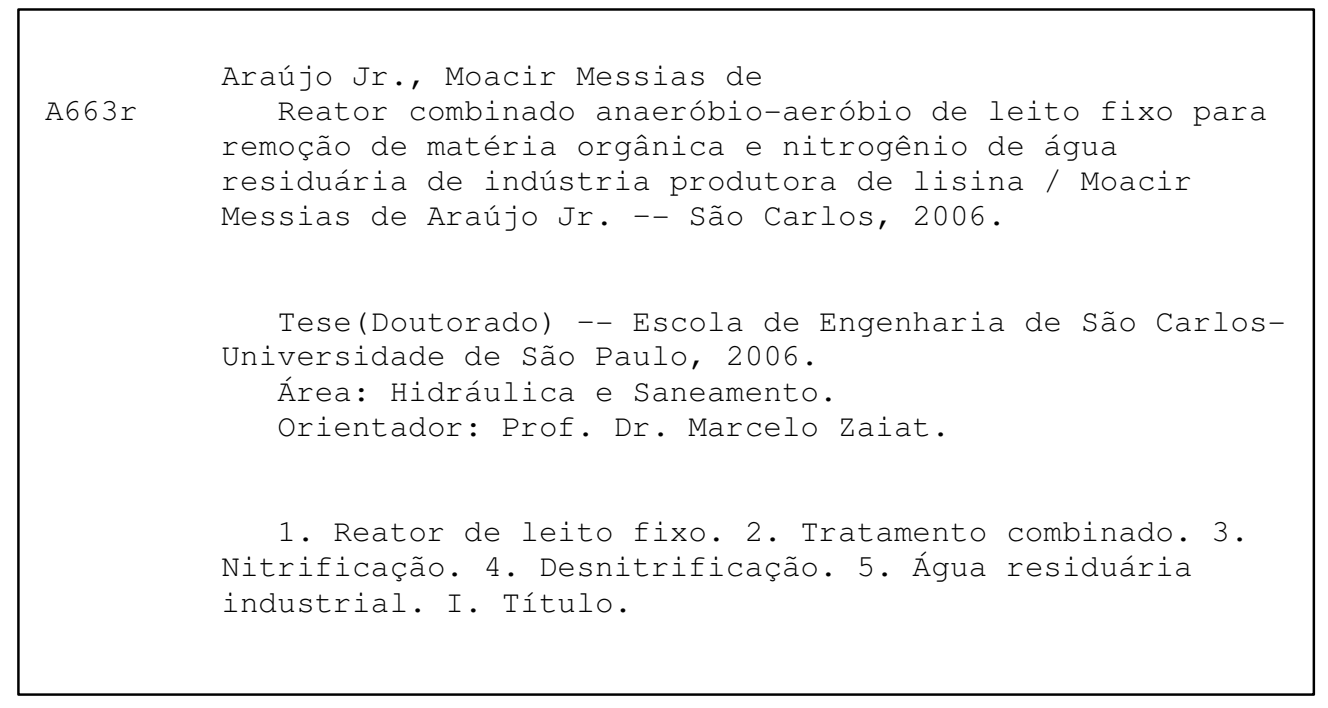




\section{FOLHA DE JULGAMENTO}

Candidato: Engenheiro MOACIR MESSIAS DE ARAUJO JUNIOR

Tese defendida e julgada em 21-07-2006 perante a Comissão Julgadora:

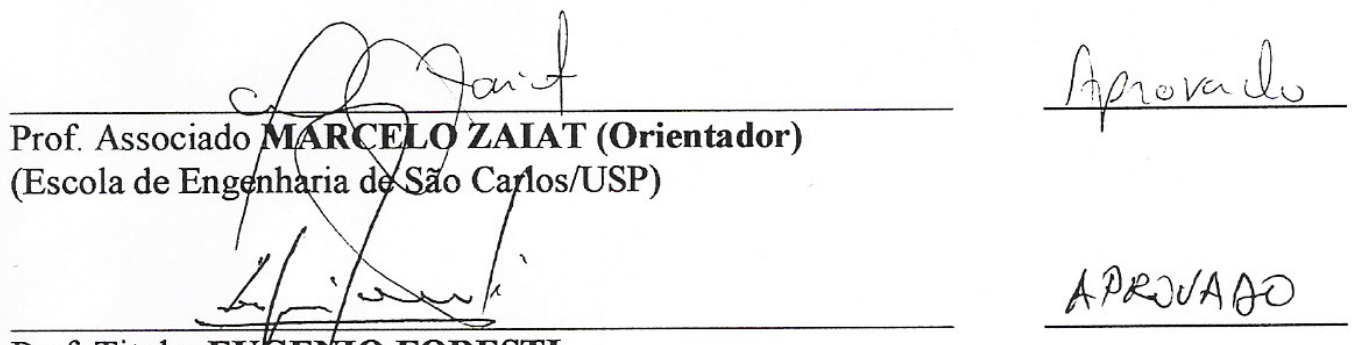

Prof. Titular EUGEXIO FORESTI

(Escola de Engenharia de São Carlos/USP)

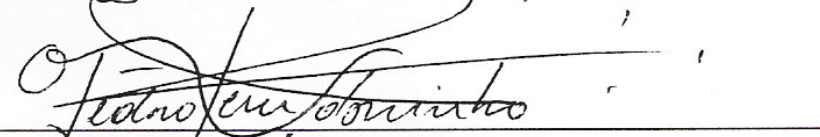

APROVAOV

Prof. Titular PEDRO ALEM SOBRINHO

(Escola Politécnica/USP)

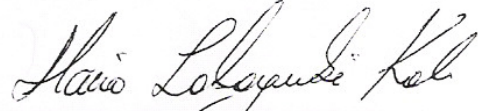

APROLADO

Prof. Dr. MÁRIO TAKAYUKI KATO

(Universidade Federal de Pernambuco/UFPE)

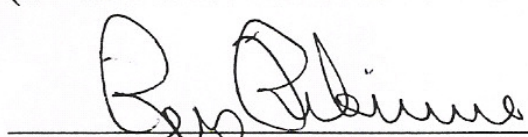

Prof. Dr. RQGERS RIBEIRO

(Instituto deEnsino Superior/UniCOC)

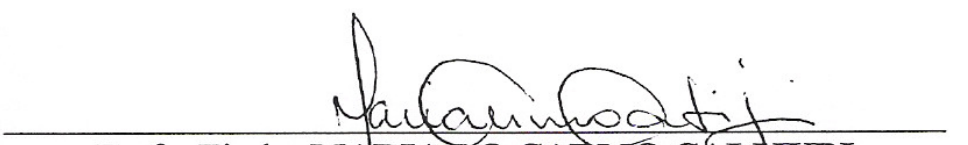

Profa. Titular MARIA DO CARMO CALIJURI

Coordenadora do Programa de Pós-Graduaçao em

Engenharia (Hidráulica e Saneamento) e

Presidente da Comissão de Pós-Graduação 

Um dia discursa a outro dia, e uma noite mostra sabedoria a outra noite.

Não há linguagem, nem há palavras, $e$ deles não se houve nenhum som;

No entanto, por toda a terra se faz ouvir a sua voz, e as suas palavras até aos confins do mundo...

... A lei do Senhor é perfeita e restaura a alma; o testemunho do Senhor é fiel, e dá sabedoria aos simplices...

... Que as palavras dos meus lábios e o meditar do meu coração sejam agradáveis na tua presença, Senhor, rocha minha e redentor meu!

(Salmo 19) 

Dedico esta Tese à minha família, em especial à minha esposa Thaís e aos meus pais Moacir e Noemia. 



\section{Agradecimentos}

Agradeço a Deus, acima de tudo, por todas as bênçãos em mim derramadas e pelo constante auxílio em tempos de tribulação.

À minha família pela segurança, dedicação, carinho e compreensão durante todos os momentos de minha vida.

Ao professor Marcelo Zaiat pela excelente orientação, desde os tempos de iniciação científica, sempre com sabedoria e bom humor.

Aos amigos da Ajinomoto Valparaíso: Fabiano Melo, Vinicios Siqueira, Rodrigo Rodrigues, Oliver Onofre Jr., Willians Lima e Fernando Nascimento pela colaboração durante toda a fase experimental. Em especial ao amigo Luiz Fernando Bezerra pela dedicação dispensada, sem a qual não seria possível a conclusão deste trabalho.

Ao Sr. Mitsuhiro Kishino pela oportunidade de trabalhar na Ajinomoto e pela confiança em mim depositada.

Aos professores Eugênio Foresti e Eduardo Cleto Pires pelas sugestões e avaliação do Plano de Qualificação.

À Eloísa Pozzi pela fundamental ajuda durante os exames microbiológicos.

À Ajinomoto de Valparaíso, na pessoa do Sr. Francisco Silveira, por apoiar o desenvolvimento desta pesquisa. 



\section{RESUMO}

ARAUJO JR., M.M. (2006). Reator combinado anaeróbio-aeróbio de leito fixo para remoção de matéria orgânica e nitrogênio de água residuária de indústria produtora de lisina. São Carlos, 2006. 136p. Tese (Doutorado) - Escola de Engenharia de São Carlos, Universidade de São Paulo.

Grande parte das industrias alimentícias, principalmente as que utilizam processos fermentativos, geram efluentes com altas concentrações de material orgânico e nutrientes (principalmente de nitrogênio), necessitando de sistemas complexos para o seu tratamento. Neste sentido, o presente trabalho foi proposto com o intuito de desenvolver um sistema compacto que possa operar como única unidade de tratamento de águas residuárias industriais, tanto na remoção de matéria orgânica quanto na remoção de nitrogênio, com baixo consumo de energia e baixa produção de lodo. Constatou-se, portanto, a viabilidade técnica do reator combinado anaeróbio-aeróbio vertical de leito fixo para o tratamento de efluentes industriais contendo matéria orgânica (1400 mg DQO/l) e nitrogênio (160 mg N/l). A melhor condição operacional do reator foi conseguida aplicando-se tempo de detenção hidráulica (TDH) de 35 h (21 h na zona anaeróbia e 14 h na zona aeróbia), com base no volume útil do reator, e razão de recirculação $(\mathrm{R})$ igual a 3,5, apresentado eficiências na remoção de DQO, NTK e NT de $97 \%, 94 \%$ e $77 \%$, respectivamente, com concentrações efluentes médias de $36 \pm 10$

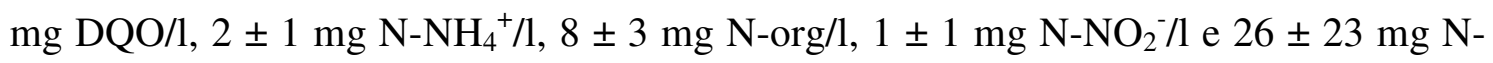
$\mathrm{NO}_{3}{ }^{-} / 1$. O reator vertical de leito fixo, operando unicamente em condição anaeróbia,

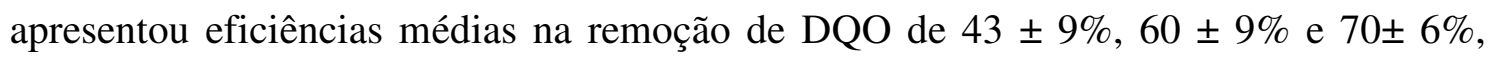
respectivamente para TDH aplicados de $11 \mathrm{~h}, 17 \mathrm{~h}$ e $21 \mathrm{~h}$.

Palavras-chave: Reator de leito fixo, tratamento combinado, nitrificação, desnitrificação, água residuária industrial. 


\section{Abstract}

ARAUJO JR., M.M. (2006). Upflow anaerobic-aerobic combined fixed bed reactor for organic matter and nitrogen removal from lysine industry wastewater. São Carlos, 2006. 136p.Thesis - Escola de Engenharia de São Carlos, Universidade de São Paulo.

Most of the food industries, mainly the ones that use fermentative processes, generates effluent with high concentrations of organic matter and nutrients (nitrogen mainly), needing of complex systems for its treatment. In this direction, the present work was considered to develop a compact system that can operate as only unit of industrial wastewater treatment, in the removal of organic matter and nitrogen, with low consumption of energy and low sludge production. Therefore, the viability of the upflow anaerobic-aerobic combined fixed bed reactor for the treatment of industrial effluent with organic matter (1400 mg COD/l) and nitrogen (160 mg N/l) was evidenced. The best operational condition of the reactor was obtained applying $35 \mathrm{~h}$ of hydraulic retention time ( $21 \mathrm{~h}$ in the anaerobic zone and $14 \mathrm{~h}$ in the aerobic zone) and recycle ratio $(\mathrm{R})$ of 3.5. In this condition, the COD, TKN and TN efficiencies removal were of $97 \%, 94 \%$ and $77 \%$, respectively, with average effluent concentrations of $10 \pm$

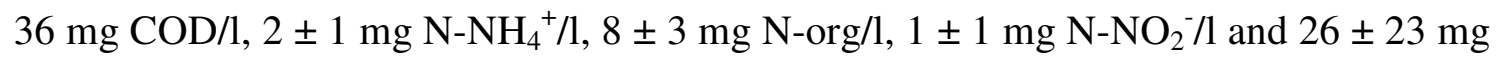
$\mathrm{N}^{-\mathrm{NO}_{3}}{ }^{-} / 1$. The up-flow fixed bed reactor, operating only in anaerobic condition, presented average efficiencies in the COD removal of $43 \pm 9 \%, 60 \pm 9 \%$ and $70 \pm 6 \%$, for HRT applied of $11 \mathrm{~h}, 17 \mathrm{~h}$ and $21 \mathrm{~h}$, respectively.

Key words: Fixed bed reactor, combined treatment, nitrification, denitrification, industrial wastewater. 


\section{Lista de Abreviaturas e Siglas}

\begin{tabular}{|c|c|}
\hline $\mathrm{AB}$ & Alcalinidade a bicarbonato \\
\hline ANAMOX & Anaerobic ammonium oxidation \\
\hline AVT & Ácidos voláteis totais \\
\hline CANON & Completely autotrophic nitrogen removal over nitrite \\
\hline $\mathrm{COV}$ & Carga orgânica volumétrica \\
\hline CVN & Carga volumétrica de nitrogênio \\
\hline DBO & Demanda bioquímica de oxigênio \\
\hline DQO & Demanda química de oxigênio \\
\hline $\mathrm{E}_{\mathrm{DN}}$ & Eficiência de desnitrificação \\
\hline $\mathrm{E}_{\mathrm{DQO}}$ & Eficiência na remoção de DQO \\
\hline EPTO & Eletronics and photonics technology office \\
\hline $\mathrm{k}_{\mathrm{d}}$ & Coeficiente de decaimento endógeno \\
\hline $\mathrm{K}_{\mathrm{S}}$ & Constante de saturação do substrato \\
\hline MBR & Membrane bioreactor \\
\hline N-amoniacal & Nitrogênio na forma amoniacal $\left(\mathrm{N}-\mathrm{NH}_{4}{ }^{+}+\mathrm{N}-\mathrm{NH}_{3}\right)$ \\
\hline $\mathrm{N}_{\mathrm{e}}$ & Nitrogênio efluente na forma de nitrito e nitrato \\
\hline NMP & Número mais provável \\
\hline $\mathrm{N}-\mathrm{NH}_{3}$ & Nitrogênio na forma de gás amônia \\
\hline $\mathrm{N}-\mathrm{NH}_{4}{ }^{+}$ & Nitrogênio na forma de íon amônio \\
\hline $\mathrm{N}_{\text {nitr }}$ & Nitrogênio nitrificado \\
\hline $\mathrm{N}-\mathrm{NO}_{2}^{-}$ & Nitrogênio na forma de nitrito (N-nitrito) \\
\hline $\mathrm{N}-\mathrm{NO}_{3}^{-}$ & Nitrogênio na forma de nitrato (N-nitrato) \\
\hline $\mathrm{N}$-org & Nitrogênio na forma orgânica \\
\hline NT & Nitrogênio total $\left(\mathrm{NTK}+\mathrm{N}-\mathrm{NO}_{2}^{-}+\mathrm{N}-\mathrm{NO}_{3}^{-}\right)$ \\
\hline NTK & Nitrogênio total Kjeldahl \\
\hline
\end{tabular}


OD Oxigênio dissolvido

OLAND Oxygen-limited nitrification and denitrification

$\mathrm{pH} \quad$ Potencial hidrogeniônico

PROSAB Programa de pesquisa em saneamento básico

Q Vazão afluente

Q $\quad$ Vazão de recirculação

R Razão de recirculação

SBR Sequencing batch reactor

SHARON Single reactor system for high ammonia removal over nitrite

SST Sólidos em suspensão totais

SSV Sólidos em suspensão voláteis

ST Sólidos totais

SVT Sólidos voláteis totais

T Temperatura

TDH Tempo de detenção hidráulica

UASB Upflow anaerobic sludge blanket

UBAF Upflow biological aerated filter

Y Coeficiente de produção celular

$\mu_{\mathrm{m}} \quad$ Velocidade máxima de crescimento específico celular 


\section{Lista de Figuras}

Figura 3.1 - Transformações do nitrogênio em sistemas de tratamento convencionais.

Figura 3.2 - Fluxograma simplificado dos sistemas de tratamento convencionais para remoção de nitrogênio (METCALF \& EDDY, 2003).

Figura 3.3 - Fluxograma simplificado do sistema de lodos ativados para remoção de nitrogênio com reatores aeróbio e anóxico independentes (CARRERA et al., 2003).

Figura 4.1 - Fluxograma da produção de Lisina na fábrica da Ajinomoto, Valparaíso, SP.

Figura 4.2 - Fotos da montagem experimental: (a) reator combinado anaeróbioaeróbio vertical de leito fixo; (b) sistema de alimentação e recirculação interna (bombas diafragma e tanque de armazenamento de água residuária).

Figura 4.3 - Desenho dimensional do reator combinado anaeróbio-aeróbio de leito fixo (medidas em centímetro).

Figura 4.4 - Pontos de amostragem de biomassa para exames microbiológicos.

Figura 4.5 - Desenho esquemático do reator anaeróbio vertical de leito fixo.

Figura 4.6 - Desenho esquemático do reator combinado anaeróbio-aeróbio vertical de leito fixo.

Figura 4.7 - Desenho esquemático dos reatores anaeróbio e aeróbio verticais de leito fixo em série.

Figura 4.8 - Desenho esquemático do reator combinado anaeróbio-aeróbio vertical de leito fixo com recirculação interna de efluente tratado.

Figura 5.1 - Eficiência na remoção de DQO ao longo do tempo de operação do reator anaeróbio vertical de leito fixo.

Figura 5.2 - Eficiência na remoção de SST ao longo do tempo de operação do reator anaeróbio vertical de leito fixo.

Figura 5.3 - Eficiência na remoção de N-org ao longo do tempo de operação do reator anaeróbio vertical de leito fixo.

Figura 5.4 -DQO na alimentação, no efluente tratado e no efluente tratado filtrado do reator anaeróbio de leito fixo ao longo do tempo de operação. 
Figura 5.5 - Gráfico Box-plot de distribuição dos resultados de DQO afluente e efluente para cada TDH aplicado.

Figura 5.6 - pH na alimentação e no efluente tratado do reator anaeróbio de leito fixo ao longo do tempo de operação.

Figura 5.7 - Alcalinidade a bicarbonato na alimentação e no efluente tratado do reator anaeróbio de leito fixo ao longo do tempo de operação.

Figura 5.8 - Ácidos voláteis totais na alimentação e no efluente tratado do reator anaeróbio de leito fixo ao longo do tempo de operação.

Figura 5.9 - SST na alimentação e no efluente tratado do reator anaeróbio de leito fixo ao longo do tempo de operação.

Figura 5.10 - Concentração de nitrogênio na alimentação e no efluente tratado do reator anaeróbio de leito fixo ao longo do tempo de operação.

Figura 5.11 - Carga orgânica volumétrica (COV) na alimentação do reator anaeróbio de leito fixo ao longo do tempo de operação, para cada TDH aplicado.

Figura 5.12 - Curvas ajustadas (Equações 5.1 e 5.2) que relacionam a eficiência média de remoção de DQO com o tempo de detenção hidráulica e a carga orgânica volumétrica.

Figura 5.13 - Eficiência na remoção de DQO e SST ao longo do tempo de operação do reator combinado anaeróbio-aeróbio vertical de leito fixo.

Figura 5.14 - Eficiência na remoção de NTK e NT ao longo do tempo de operação do reator combinado anaeróbio-aeróbio vertical de leito fixo.

Figura 5.15 - Sólidos suspensos totais (SST) na alimentação e no efluente tratado do reator combinado anaeróbio-aeróbio vertical de leito fixo ao longo do tempo de operação.

Figura 5.16 - DQO na alimentação e no efluente tratado do reator combinado anaeróbio-aeróbio vertical de leito fixo ao longo do tempo de operação.

Figura 5.17 - Ácidos voláteis totais (AVT) na alimentação e no efluente tratado do reator combinado anaeróbio-aeróbio vertical de leito fixo ao longo do tempo de operação.

Figura 5.18 - NTK na alimentação e no efluente tratado do reator combinado anaeróbio-aeróbio vertical de leito fixo ao longo do tempo de operação.

Figura 5.19 - Alcalinidade a bicarbonato na alimentação e no efluente tratado do reator combinado anaeróbio-aeróbio vertical de leito fixo ao longo do tempo de operação.

Figura 5.20 - pH na alimentação e no efluente tratado do reator combinado anaeróbio-aeróbio vertical de leito fixo ao longo do tempo de operação. 
Figura 5.21 - Concentrações efluentes de $\mathrm{N}$-amoniacal, N-nitrito e N-nitrato do reator combinado anaeróbio-aeróbio vertical de leito fixo ao longo do tempo de operação.

Figura 5.22 - Nitrogênio total (NT) na alimentação e no efluente tratado do reator combinado anaeróbio-aeróbio vertical de leito fixo ao longo do tempo de operação.

Figura 5.23 - Oxigênio dissolvido (OD) na alimentação e no efluente tratado do reator combinado anaeróbio-aeróbio vertical de leito fixo ao longo do tempo de operação.

Figura 5.24 - Carga orgânica volumétrica (COV) aplicada ao reator combinado anaeróbio-aeróbio vertical de leito fixo e carga volumétrica de nitrogênio $(\mathrm{CVN})$ aplicada à zona aeróbia do reator ao longo do tempo de operação.

Figura 5.25 - Eficiência na remoção de DQO e SST ao longo do tempo de operação do sistema com reatores anaeróbio com aeração no topo e aeróbio verticais de leito fixo em série.

Figura 5.26 - Eficiência na remoção de NTK e NT ao longo do tempo de operação do sistema com reatores anaeróbio com aeração no topo e aeróbio verticais de leito fixo em série.

Figura 5.27 - DQO na alimentação e nos efluentes dos reatores anaeróbio com aeração no topo e aeróbio verticais de leito fixo ao longo do tempo de operação do sistema.

Figura 5.28 - Ácidos voláteis totais na alimentação e nos efluentes dos reatores anaeróbio com aeração no topo e aeróbio verticais de leito fixo ao longo do tempo de operação do sistema.

Figura 5.29 - NTK na alimentação e no efluente dos reatores anaeróbio com aeração no topo e aeróbio verticais de leito fixo ao longo do tempo de operação do sistema.

Figura 5.30 - Concentrações de N-amoniacal, N-nitrito e N-nitrato no efluente do reator anaeróbio vertical de leito fixo com aeração no topo ao longo do tempo de operação.

Figura 5.31 - Concentrações de N-amoniacal, N-nitrito e N-nitrato no efluente do reator aeróbio vertical de leito fixo ao longo do tempo de operação.

Figura 5.32 - Nitrogênio total (NT) na alimentação e nos efluentes dos reatores anaeróbio com aeração no topo e aeróbio verticais de leito fixo ao longo do tempo de operação do sistema.

Figura 5.33 - Alcalinidade a bicarbonato na alimentação e no efluente dos reatores anaeróbio e aeróbio verticais de leito fixo ao longo do tempo de operação do sistema.

Figura 5.34 - pH na alimentação e no efluente dos reatores anaeróbio com aeração no topo e aeróbio verticais de leito fixo ao longo do tempo de operação do sistema. 
Figura 5.35 - Oxigênio dissolvido na alimentação e no efluente do reator aeróbio vertical de leito fixo ao longo do tempo de operação do sistema.

Figura 5.36 - Eficiência na remoção de DQO e SST ao longo do tempo de operação do reator combinado anaeróbio-aeróbio vertical de leito fixo, para cada razão de recirculação (R) aplicada.

Figura 5.37 - Eficiência na remoção de NTK e NT ao longo do tempo de operação do reator combinado anaeróbio-aeróbio vertical de leito fixo, para cada razão de recirculação (R) aplicada.

Figura 5.38 - DQO na alimentação, no efluente tratado e no efluente tratado filtrado do reator combinado anaeróbio-aeróbio vertical de leito fixo ao longo do tempo de operação, para cada razão de recirculação (R) aplicada.

Figura 5.39 - Sólidos suspensos totais (SST) na alimentação e no efluente tratado do reator combinado anaeróbio-aeróbio vertical de leito fixo ao longo do tempo de operação, para cada razão de recirculação (R) aplicada.

Figura 5.40 - Gráfico Box-plot de distribuição dos resultados de DQO afluente e efluente do reator combinado anaeróbio-aeróbio vertical de leito fixo para cada razão de recirculação (R) aplicada.

Figura 5.41 - Ácidos voláteis totais na alimentação e no efluente tratado do reator combinado anaeróbio-aeróbio vertical de leito fixo ao longo do tempo de operação, para cada razão de recirculação $(\mathrm{R})$ aplicada.

Figura 5.42 - NTK na alimentação e no efluente tratado do reator combinado anaeróbio-aeróbio vertical de leito fixo ao longo do tempo de operação, para cada razão de recirculação $(\mathrm{R})$ aplicada.

Figura 5.43 - Concentração de oxigênio dissolvido na zona aeróbia do reator combinado anaeróbio-aeróbio vertical de leito fixo ao longo do tempo de operação, para cada razão de recirculação (R) aplicada.

Figura 5.44 - Gráfico Box-plot de distribuição dos resultados de NTK afluente e efluente do reator combinado anaeróbio-aeróbio vertical de leito fixo para cada razão de recirculação (R) aplicada.

Figura 5.45 - Concentração de N-nitrato, N-nitrito, N-amoniacal e N-org no efluente tratado do reator combinado anaeróbio-aeróbio vertical de leito fixo ao longo do tempo de operação, para cada razão de recirculação $(\mathrm{R})$ aplicada.

Figura 5.46 - Nitrogênio total (NT) na alimentação e no efluente tratado do reator combinado anaeróbio-aeróbio vertical de leito fixo ao longo do tempo de operação, para cada razão de recirculação $(\mathrm{R})$ aplicada.

Figura 5.47 - Gráfico Box-plot de distribuição dos resultados de nitrogênio total (NT) afluente e efluente do reator combinado anaeróbio-aeróbio vertical de leito fixo para cada razão de recirculação $(\mathrm{R})$ aplicada. 
Figura 5.48 - Alcalinidade a bicarbonato na alimentação e no efluente tratado do reator combinado anaeróbio-aeróbio vertical de leito fixo ao longo do tempo de operação, para cada razão de recirculação (R) aplicada.

Figura 5.49 - pH na alimentação e no efluente tratado do reator combinado anaeróbio-aeróbio vertical de leito fixo ao longo do tempo de operação, para cada razão de recirculação $(\mathrm{R})$ aplicada.

Figura 5.50 - Eficiências de desnitrificação $\left(\mathrm{E}_{\mathrm{DN}}\right)$ empíricas e teóricas em função da razão de recirculação interna aplicada $(\mathrm{R})$.

Figura 5.51 - Carga orgânica volumétrica (COV) e carga volumétrica de nitrogênio $(\mathrm{CVN})$ aplicadas ao longo da operação do reator combinado anaeróbio-aeróbio vertical de leito fixo com recirculação interna de efluente tratado.

Figura 5.52 - Fotos do afluente e efluente do reator combinado anaeróbioaeróbio vertical de leito fixo com recirculação interna de efluente tratado.

Figura 5.53 - Fotos das amostras de biomassa (suspensa e aderida nos suportes) coletadas ao longo do reator combinado anaeróbio-aeróbio vertical de leito fixo.

Figura 5.54- Observações morfológicas sob microscopia ótica referente à biomassa aderida ao suporte de argila expandida na zona anaeróbia do reator combinado anaeróbio-aeróbio vertical de leito fixo (ponto de amostragem 1)

Figura 5.55 - Observações morfológicas sob microscopia ótica referente à biomassa aderida aos suportes de espuma de poliuretano na zona anaeróbia do reator combinado anaeróbio-aeróbio vertical de leito fixo (pontos de amostragem 2 e 3 ).

Figura 5.56 - Observações morfológicas sob microscopia ótica referente à biomassa suspensa coletada na interface entre as zonas anaeróbia e aeróbia do reator combinado anaeróbio-aeróbio vertical de leito fixo (ponto de amostragem 4).

Figura 5.57 - Observações morfológicas sob microscopia ótica referente à biomassa aderida aos suportes de espuma de poliuretano na zona aeróbia do reator combinado anaeróbio-aeróbio vertical de leito fixo (pontos de amostragem 5 e 6 ). 


\section{Lista DE TABElaS}

Tabela 3.1 - Coeficientes cinéticos de nitrificação a $20^{\circ} \mathrm{C}$, em sistema de lodos ativados.

Tabela 4.1 - Características dos suportes utilizados para imobilização da biomassa.

Tabela 4.2 - Composição média da água residuária industrial estudada.

Tabela 4.3 - Tipo de exame microbiológico realizado para cada ponto de amostragem.

Tabela 4.4 - Composição química dos meios de cultura para bactérias oxidadoras de amônia e oxidadoras de nitrito.

Tabela 4.5 - Variáveis analisadas, métodos utilizados e frequiência de amostragem durante a operação do reator anaeróbio vertical de leito fixo.

Tabela 4.6 - Variáveis analisadas, pontos de amostragem, métodos analíticos utilizados e frequiência de amostragem durante a operação do reator combinado anaeróbio-aeróbio vertical de leito fixo.

Tabela 4.7 - Variáveis analisadas, pontos de amostragem, métodos analíticos utilizados e freqüência de amostragem durante a operação do sistema com reatores anaeróbio e aeróbio de verticais de leito fixo em série.

Tabela 4.8 - Variáveis analisadas, pontos de amostragem, métodos analíticos utilizados e frequiência de amostragem durante a operação do reator combinado anaeróbio-aeróbio vertical de leito fixo com recirculação interna de efluente tratado.

Tabela 4.9 - Resumo das etapas experimentais do reator vertical de leito fixo.

Tabela 5.1 - Resultados médios de DQO afluente, DQO efluente e de eficiência na remoção de DQO ( $\left.\mathrm{E}_{\mathrm{DQO}}\right)$ em função do tempo de detenção hidráulica (TDH) e da carga orgânica volumétrica (COV) aplicada.

Tabela 5.2 - Parâmetros operacionais e performance de sistemas anaeróbios de leito fixo tratando água residuária industrial.

Tabela 5.3 - Resultados médios dos parâmetros analisados durante a operação do reator anaeróbio vertical de leito fixo. 
Tabela 5.4 - Comparação entre os parâmetros operacionais de sistemas de tratamento por lodos ativados e reator combinado anaeróbioaeróbio vertical de leito fixo.

Tabela 5.5 - Resultados médios dos parâmetros analisados durante a operação do reator combinado anaeróbio-aeróbio vertical de leito fixo.

Tabela 5.6 - Eficiências alcançadas na remoção de DQO, SST, NTK e NT para os sistemas combinados anaeróbio-aeróbio com reatores conjugados e separados.

Tabela 5.7 - Resultados médios dos parâmetros analisados durante a operação do sistema com reatores anaeróbio e aeróbio verticais de leito fixo em série.

Tabela 5.8 - Quantidade de nitrogênio nitrificado $\left(\mathrm{N}_{\text {nitr }}\right)$, concentração efluente de nitrogênio na forma de nitrito e nitrato $\left(\mathrm{N}_{\mathrm{e}}\right)$ e eficiência de desnitrificação $\left(\mathrm{E}_{\mathrm{DN}}\right)$ em função da razão de recirculação interna aplicada (R).

Tabela 5.9 - Comparação entre o reator combinado anaeróbio-aeróbio vertical de leito fixo com recirculação inferna de efluente e alguns sistemas de tratamento de águas residuárias industriais citados na literatura.

Tabela 5.10 - Resultados médios dos parâmetros analisados durante a operação do reator combinado anaeróbio-aeróbio vertical de leito fixo com recirculação de efluente tratado.

Tabela 5.11 - Sólidos totais (ST) e sólidos voláteis totais (SVT) aderidos por massa de suporte.

Tabela 5.12 - Concentrações estimadas de sólidos totais (ST) e sólidos voláteis totais (SVT) no leito do reator combinado anaeróbio-aeróbio vertical de leito fixo.

Tabela 5.13 - Resultados de NMP de bactérias heterótrofas, nitrificantes e desnitrificantes por grama de sólidos voláteis totais (SVT) aderidos nos suportes.

Tabela 5.14 - Ocorrência das morfologias observadas na zona anaeróbia do reator combinado anaeróbio-aeróbio vertical de leito fixo.

Tabela 5.15 - Ocorrência das morfologias observadas na zona aeróbia do reator combinado anaeróbio-aeróbio vertical de leito fixo. 


\section{SUMÁRIO}

RESUMO

$\begin{array}{lll}\text { ABSTRACT } & \text { ii }\end{array}$

LISTA DE ABREVIATURAS E SIGLAS iii

LISTA DE FIGURAS v v

LISTA DE TABELAS X X

1 INTRODUÇÃO

2 OBJETIVOS 3

2.1 Objetivo geral 3

2.2 Objetivos específicos 3

3 REVISÃO BIBLIOGRÁFICA 5

3.1 Sistemas combinados anaeróbio-aeróbio para tratamento de águas residuárias

3.2 Processo convencional para remoção biológica de nitrogênio 7

$\begin{array}{ll}3.2 .1 \text { Processo de amonificação e assimilação } & 7\end{array}$

3.2.2 Processo de nitrificação $\quad 8$

3.2.3 Processo de desnitrificação $\quad 12$

3.3 Novos conceitos e tecnologias na remoção biológica de nitrogênio 15

$\begin{array}{ll}\text { 3.3.1 Nitrificação parcial } & 15\end{array}$

$\begin{array}{ll}\text { 3.3.2 Processo ANAMMOX } & 17\end{array}$

3.3.3 Processo CANON 18

$\begin{array}{ll}\text { 3.3.4 Processo } \mathrm{NO}_{\mathrm{x}} & 19\end{array}$

$\begin{array}{ll}\text { 3.3.5 Processo OLAND } & 20\end{array}$

3.4 Biomassa imobilizada em suporte inerte $\quad 21$

3.5 Remoção de matéria orgânica e nitrogênio de águas residuárias industriais

$\begin{array}{ll}\text { 3.6 Considerações finais } & 26\end{array}$

4 MATERIAL E MÉTODOS 29

$\begin{array}{ll}\text { 4.1 Descrição geral dos experimentos } & 29\end{array}$

$\begin{array}{ll}4.2 \text { reator em escala de bancada } & 30\end{array}$ 
4.3 Suportes para imobilização da biomassa 34

4.4 Água residuária $\quad 34$

4.5 Inóculo $\quad 35$

4.6 Análises físico-químicas $\quad 35$

354.6.1 Quantificação da biomassa aderida nos suportes 37

$\begin{array}{ll}\text { 4.7 Exames microbiológicos } & 38\end{array}$

4.7.1 Caracterização morfológica do biofilme 39

4.7.2 Número mais provável (NMP) de bactérias nitrificantes 39

4.7.3 Número mais provável (NMP) de bactérias heterótrofas e desnitrificantes 42

4.8 Procedimento experimental 43

4.8.1 Etapa 1 - Reator anaeróbio vertical de leito fixo 44

4.8.2 Etapa 2 - Reator combinado anaeróbio-aeróbio vertical de leito fixo

4.8.3 Etapa 3 - Reator anaeróbio vertical de leito fixo em série com reator aeróbio vertical de leito

4.8.4 Etapa 4 - Reator combinado anaeróbio-aeróbio vertical de leito fixo com recirculação interna de efluente tratado 52

4.8.5 Resumo das etapas experimentais $\quad 55$

5 RESULTADOS E DISCUSSÃO 57

5.1 Etapa 1 - Reator anaeróbio vertical de leito fixo $\quad 57$

5.2 Etapa 2 - Reator combinado anaeróbio-aeróbio vertical de leito fixo

5.3 Etapa 3 - Reator anaeróbio vertical de leito fixo em série com reator aeróbio vertical de leito fixo

5.4 Etapa 4 - Reator combinado anaeróbio-aeróbio vertical de leito fixo com recirculação interna de efluente tratado 96

5.5 Exames microbiológicos 113

5.5.1 Quantificação da biomassa aderida nos suportes $\quad 114$

5.5.2 Número mais provável (NMP) de bactérias no biofilme $\quad 116$

5.5.3 Caracterização morfológica do biofilme 117

5.6 Considerações sobre a operacionalidade do reator 123

6 CONCLUSÕES 125

7 SUGESTÕES 129

8 REFERÊNCIAS BIBLIOGRÁFICAS 131 



\section{Introdução}

A partir da década de sessenta, observou-se que o tratamento secundário não era suficiente para um combate eficiente à poluição das águas de superfícies e que a aplicação de nitrificação, embora benéfica para a qualidade do efluente, nem sempre eliminava os problemas por completo. Estabeleceu-se que a descarga de grandes quantidades de nutrientes, notadamente nitrogênio e fósforo, tendia a causar sério desequilíbrio ecológico nos corpos d'água receptores. Esse fenômeno, chamado de eutrofização, se devia ao crescimento exacerbado da vida aquática, que podia se desenvolver graças à presença de teores elevados de nutrientes. Para proteger os corpos d'água receptores de efluentes, tornou-se necessário desenvolver sistemas de tratamento terciário, isto é, sistemas que, além dos sólidos sedimentáveis (tratamento primário) e do material orgânico (tratamento secundário), também pudessem remover os nutrientes, nitrogênio e fósforo (van HAANDEL \& MARAIS, 1999).

Devido ao seu baixo custo operacional e reduzida geração de lodo, os reatores anaeróbios se colocam em posição de destaque para o tratamento de águas residuárias visando a remoção de matéria orgânica, principalmente em regiões tropicais e subtropicais onde a temperatura ambiente favorece a digestão anaeróbia. Contudo, dificilmente esses reatores produzem efluentes que atendem aos padrões estabelecidos pela legislação ambiental brasileira, além de terem pouco efeito sobre os macronutrientes ( $\mathrm{N}$ e $\mathrm{P}$ ), necessitando de uma etapa de pós-tratamento.

Entre as opções de tratamento de efluentes líquidos, os sistemas combinados anaeróbio-aeróbio mostram-se promissores, principalmente quando, além da redução da matéria orgânica, deseja-se a remoção de nutrientes, em particular do nitrogênio orgânico e amoniacal. Entre as vantagens dos sistemas combinados anaeróbio-aeróbio destacam-se a baixa potência de aeração requerida na fase aeróbia, menor produção de 
lodo biológico e baixo custo de implantação e operação, quando comparados aos sistemas convencionais por lodos ativados.

Grande parte das industrias alimentícias, principalmente as que utilizam processos fermentativos, geram efluentes com altas concentrações de material orgânico e de nutrientes (principalmente nitrogênio). Atualmente, os sistemas mais utilizados para o seu tratamento são os sistemas de lodos ativados com zonas pré e/ou pósanóxicas. Esses processos de tratamento, além de necessitarem de grandes áreas para a sua implantação, possuem custos operacionais elevados, principalmente devido a alta demanda de energia elétrica e alta geração de lodo, inviabilizando, em muitos casos, a sua completa instalação.

Neste contexto, o presente trabalho propõe o estudo de uma nova configuração de reator que possa operar como única unidade de tratamento destas águas residuárias, tanto na remoção de matéria orgânica quanto na remoção de nitrogênio, com baixo consumo de energia e baixa formação de lodo. A configuração proposta é um reator misto, vertical de leito fixo, constituído por dois compartimentos superpostos que operam sob condições anaeróbias e aeróbias, respectivamente. 


\section{2 Оветтіо}

\subsection{OBJETIVO GERAL}

O objetivo principal do trabalho foi avaliar o desempenho do reator combinado anaeróbio-aeróbio vertical de leito fixo para o tratamento de água residuária de indústria produtora de lisina, visando a remoção de matéria orgânica e nitrogênio.

\subsection{OBJETIVOS ESPECÍFICOS}

Os objetivos específicos do trabalho foram :

- Avaliar o desempenho do reator vertical de leito fixo operando unicamente em condição anaeróbia para diferentes tempos de detenção hidráulica aplicados;

- Comparar o desempenho dos sistemas combinados anaeróbio-aeróbio operando com reatores conjugados (zonas anaeróbia e aeróbia sobrepostas em um único reator) e separados (reatores anaeróbio e aeróbio independentes, operando sem série);

- Avaliar a eficiência de desnitrificação do reator combinado anaeróbioaeróbio vertical de leito fixo operando com recirculação interna de efluente tratado. 



\section{Revisão Bibliográfica}

\subsection{SISTEMAS COMBINADOS ANAERÓBIO-AERÓBIO PARA TRATAMENTO DE ÁGUAS RESIDUÁRIAS}

Em que se pesem as suas grandes vantagens, os reatores anaeróbios dificilmente produzem efluentes que atendam aos padrões estabelecidos pela legislação ambiental brasileira. Portanto, torna-se de grande importância o pós-tratamento desses efluentes como uma forma de atender aos requisitos legais e propiciar a proteção dos corpos d'água receptores. Além da complementação na remoção de matéria orgânica, o póstratamento tem por objetivo a remoção de constituintes pouco afetados nos processos anaeróbios, tais como nutrientes ( $\mathrm{N}$ e $\mathrm{P})$ e organismos patogênicos.

No âmbito do PROSAB (Programa de Pesquisa em Saneamento Básico), foram alcançados avanços significativos no desenvolvimento de alternativas tecnológicas para o pós-tratamento de efluentes de reatores anaeróbios tratando esgoto sanitário. Entre as principais alternativas destacam-se (PROSAB, 2001):

- Sistemas de aplicação no solo (irrigação, escoamento superficial e infiltração rápida);

- Sistemas de lagoas de polimento;

- Reatores com biofilme (filtros biológicos percoladores, biodiscos, biofiltro aerado submerso, reatores de leito fluidificado ou expandido, filtros anaeróbios, reator radial de leito fixo);

- Sistemas de lodos ativados (contínuos e em batelada);

- Sistemas de flotação por ar dissolvido;

- Sistemas de desinfecção (cloro, radiação ultravioleta e ozônio). 
Das opções de tratamento de efluentes líquidos, os sistemas combinados anaeróbio-aeróbios mostram-se promissores, principalmente quando, além da redução da matéria orgânica, deseja-se a remoção de nutrientes, em particular o nitrogênio orgânico e amoniacal.

De acordo com Chernicharo (2006), a utilização de processos combinados anaeróbio-aeróbio propicia uma série de vantagens perante as estações de tratamento aeróbias convencionais, tais como baixa potência de aeração requerida na fase aeróbia, menor produção de lodo biológico e baixo custo de implantação e operação. Em sistemas combinados UASB (upflow anaerobic sludge blanket)/lodos ativados ou UASB/reator de biofilme aerado o excesso de lodo gerado no reator aeróbio pode ser direcionado para o reator UASB, onde é digerido e adensado juntamente com o lodo anaeróbio, dispensando unidades de digestão e adensamento adicionais.

Estudos conduzidos por Gonçalves et al. (2000) mostraram que o sistema combinado UASB/reator de biofiltro aerado submerso é capaz de manter condições estáveis de operação apesar das variações de carga afluente e do reciclo de lodo descartado do reator aeróbio para o reator anaeróbio. Segundo o autor, os valores médios de DQO (demanda química de oxigênio) e SST (sólidos em suspensão totais) no efluente final para esse sistema são usualmente mantidos abaixo de 90mg DQO/l e 30 $\operatorname{mg~SST/1.~}$

Resultados de pesquisas desenvolvidas por Aisse et al. (2000), Chernicharo \& Nascimento (2001) e Pontes et. al. (2003) mostraram que a utilização de filtros percoladores como unidade de pós-tratamento de reator UASB é uma alternativa viável para o tratamento de esgoto sanitário, produzindo efluente final com valores médios de DQO, DBO (demanda bioquímica de oxigênio) e SST da ordem de 120 mg DQO/l, 40 $\mathrm{mg} \mathrm{DBO} / \mathrm{l}$ e $30 \mathrm{mg} \mathrm{SST} / 1$.

Callado \& Foresti (2001), operando um sistema anaeróbio-aeróbio composto por reatores seqüenciais em batelada $(\mathrm{SBR})$ em série, alcançaram altas eficiências de remoção de DQO, nitrogênio e fósforo de esgoto sanitário. A nitrificação, desnitrificação e a remoção biológica de fósforo ocorriam no segundo reator SBR, operado sob ciclos aeróbio e anóxico, tratando efluente do reator anaeróbio. Para a efetiva desnitrificação e remoção de fósforo, foi necessária a suplementação de carbono com acetato.

Foresti et al. (2006) destaca que devido a significativa remoção de matéria orgânica, os efluentes dos reatores anaeróbios podem ter relação N/DQO e P/DQO 
muito alta para uma posterior remoção de nutrientes, fazendo-se necessário a adição de compostos orgânicos na etapa de desnitrificação e remoção de fósforo. Entretanto, esta deficiência abre a possibilidade de se utilizar doadores de elétrons alternativos, produzidos pelos próprios reatores anaeróbios, tais como ácidos orgânicos, álcoois, metano, compostos reduzidos de enxofre, entre outros.

\subsection{PROCESSO CONVENCIONAL PARA REMOÇÃO BIOLÓGICA DE NITROGÊNIO}

O processo básico ou convencional de remoção biológica do nitrogênio nas águas residuárias se dá pelas etapas de amonificação, assimilação, nitrificação e desnitrificação, conforme mostrado no fluxograma da Figura 3.1.

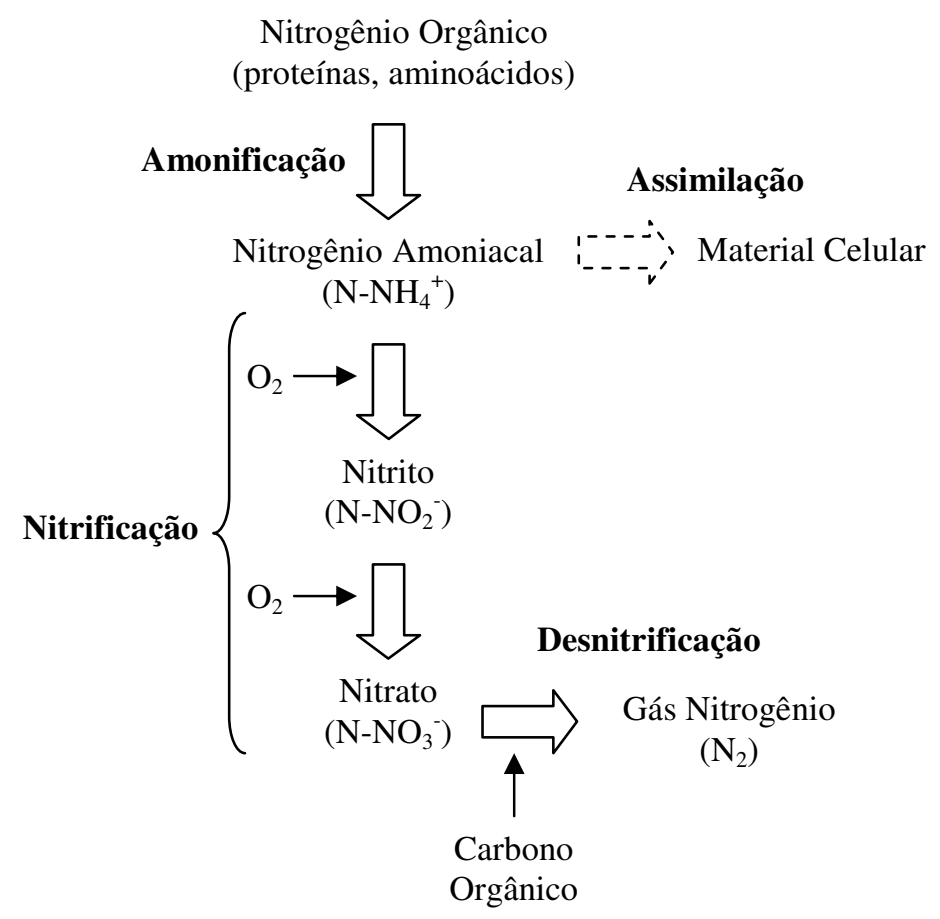

Figura 3.1 - Transformações do nitrogênio em sistemas de tratamento convencionais.

\subsubsection{Processo de amonificação e assimilação}

O processo de amonificação consiste na conversão biológica de materiais orgânicos presentes nas águas residuárias, tais como proteínas, aminoácidos e uréia em 
nitrogênio amoniacal.

$\mathrm{O}$ nitrogênio amoniacal pode se apresentar na forma de amônia $\left(\mathrm{N}-\mathrm{NH}_{3}\right)$ ou íon amônio $\left(\mathrm{N}_{-} \mathrm{NH}_{4}{ }^{+}\right)$, sendo que as proporções de cada composto dependem do $\mathrm{pH}$ e da temperatura da água residuária.

Anthonisen et al (1976) relaciona a porcentagem de nitrogênio amoniacal na forma ionizada $\left(\% \mathrm{~N}-\mathrm{NH}_{4}{ }^{+}\right)$com o $\mathrm{pH}$ e a temperatura $\mathrm{T}\left({ }^{\circ} \mathrm{C}\right)$ por meio da Equação 3.1 .

$$
\% N-N H_{4}^{+}=\left\{1-\left[\frac{1,214 * 10^{p H}}{e^{\left(\frac{6344}{273+T}\right)}+10^{p H}}\right]\right\} * 100
$$

Em reatores biológicos em que o pH é controlado em torno de 7,0 e a temperatura do meio líquido varia de $20^{\circ} \mathrm{C}$ a $35^{\circ} \mathrm{C}$, praticamente todo nitrogênio amoniacal (99\%) apresenta-se na forma ionizada $\left(\mathrm{N}-\mathrm{NH}_{4}{ }^{+}\right)$.

Admitindo-se que a biomassa bacteriana possa ser representada pela fórmula empírica $\mathrm{C}_{5} \mathrm{H}_{7} \mathrm{NO}_{2}$, estima-se que para cada $1 \mathrm{~g}$ de células formadas cerca de $0,12 \mathrm{~g}$ de $\mathrm{N}-\mathrm{NH}_{4}{ }^{+}\left(14 \mathrm{~g} \mathrm{~N} / 113 \mathrm{~g} \mathrm{C}_{5} \mathrm{H}_{7} \mathrm{NO}_{2}\right.$ ) é assimilado (METCALF \& EDDY, 2003).

Embora uma parcela do nitrogênio amoniacal possa ser assimilada na síntese celular, sua importância na remoção de nitrogênio em águas residuárias é pequena. Por isso, em processos biológicos com remoção de nitrogênio, os fenômenos da nitrificação e desnitrificação são considerados preponderantes.

\subsubsection{Processo de nitrificação}

A nitrificação é tradicionalmente definida como a oxidação do nitrogênio amoniacal $\left(\mathrm{N}^{-} \mathrm{NH}_{4}{ }^{+}\right)$a nitrato $\left(\mathrm{N}^{-\mathrm{NO}_{3}}{ }^{-}\right)$via nitrito $\left(\mathrm{N}^{-} \mathrm{NO}_{2}{ }^{-}\right)$utilizando o oxigênio molecular $\left(\mathrm{O}_{2}\right)$ como aceptor final de elétrons.

Em sistemas convencionais de tratamento, bactérias aeróbias quimioautotróficas são responsáveis pelo processo de nitrificação, as quais utilizam quase que exclusivamente o gás carbônico como fonte de carbono. Bactérias do gênero Nitrossomonas, Nitrosococcus, Nitrosospira, Nitrosolobus e Nitrosorobrio participam da etapa de nitritação (oxidação de $\mathrm{N}^{-\mathrm{NH}_{4}{ }^{+} \text {a N-NO}}{ }_{2}{ }^{-}$). A etapa de nitratação (oxidação de $\mathrm{N}_{-} \mathrm{NO}_{2}^{-}$a $\mathrm{N}^{-} \mathrm{NO}_{3}^{-}$) envolve os gêneros Nitrobacter, Nitrococcus, Nitrospira, 
Nitrospina e Nitroeystis (METCALF \& EDDY, 2003).

A reação de nitritação é realizada em duas etapas. A primeira ocorre no interior da membrana citoplasmática onde a amônia é oxidada a hidroxilamina $\left(\mathrm{NH}_{2} \mathrm{OH}\right)$, por meio da ação da enzima amônia mono-oxigenase, com os requisitos de oxigênio molecular e energia para promover a reação. Na segunda etapa, a hidroxilamina é transportada para o periplasma e convertida a nitrito, por meio da ação da enzima hidroxilamina oxidoredutase, liberando dois pares de elétrons. Um par é utilizado na primeira etapa de oxidação da amônia enquanto o segundo par é utilizado para a produção de energia e redução do oxigênio molecular em água (COLLIVER \& STEPHENSON, 2000; HAGOPIAN \& RILEY, 1998).

As reações de nitritação são apresentadas pelas Equações 3.2 a 3.5.

Oxidação:

$$
\begin{aligned}
& \mathrm{NH}_{3}+\mathrm{O}_{2}+2 \mathrm{H}^{+}+2 e^{-} \stackrel{\text { Amönia mono-oxigenase }}{\longrightarrow} \mathrm{NH}_{2} \mathrm{OH}+\mathrm{H}_{2} \mathrm{O} \\
& \mathrm{NH}_{2} \mathrm{OH}+\mathrm{H}_{2} \mathrm{O} \stackrel{\text { Hidroxilamina oxidoredutase }}{\longrightarrow} \mathrm{NO}_{2}^{-}+5 \mathrm{H}^{+}+4 e^{-}
\end{aligned}
$$

\section{Redução:}

$$
\frac{1}{2} \mathrm{O}_{2}+2 \mathrm{H}^{+}+2 e^{-} \longrightarrow \mathrm{H}_{2} \mathrm{O}
$$

Reação global:

$$
\mathrm{NH}_{3}+\frac{3}{2} \mathrm{O}_{2} \stackrel{\text { Nitritação }}{\longrightarrow} \mathrm{NO}_{2}^{-}+\mathrm{H}^{+}+\mathrm{H}_{2} \mathrm{O}
$$

A reação de nitratação é realizada pela enzima nitrito oxidoredutase com o oxigênio molecular sendo suprido pela água. A reação libera um par de elétrons que também é utilizado na produção de energia e redução do oxigênio molecular em água (COLLIVER \& STEPHENSON, 2000; HAGOPIAN \& RILEY, 1998).

As reações de nitratação são apresentadas pelas Equações 3.6 a 3.8.

Oxidação:

$$
\mathrm{NO}_{2}^{-}+\mathrm{H}^{+}+\mathrm{H}_{2} \mathrm{O} \stackrel{\text { Nitrito oxidoredutase }}{\longrightarrow} \mathrm{NO}_{3}^{-}+3 \mathrm{H}^{+}+2 e^{-}
$$


Redução:

$\frac{1}{2} \mathrm{O}_{2}+2 \mathrm{H}^{+}+2 e^{-} \longrightarrow \mathrm{H}_{2} \mathrm{O}$

Reação global:

$$
\mathrm{NO}_{2}^{-}+\frac{1}{2} \mathrm{O}_{2} \stackrel{\text { Nitratação }}{\longrightarrow} \mathrm{NO}_{3}^{-}
$$

Considerando que a biomassa bacteriana pode ser representada pela fórmula empírica $\mathrm{C}_{5} \mathrm{H}_{7} \mathrm{NO}_{2}$, segundo Metcalf \& Eddy (2003) a reação global incluindo oxidação e síntese durante a nitrificação assume a seguinte forma:

$$
\begin{aligned}
\mathrm{NH}_{4}^{+}+1,863 \mathrm{O}_{2}+0,098 \mathrm{CO}_{2} \rightarrow & 0,98 \mathrm{NO}_{3}^{-}+0,0196 \mathrm{C}_{5} \mathrm{H}_{7} \mathrm{NO}_{2}+ \\
& +0,0941 \mathrm{H}_{2} \mathrm{O}+1,98 \mathrm{H}^{+}
\end{aligned}
$$

De acordo com a Equação 3.9, para $1 \mathrm{~g}$ de $\mathrm{N}^{-\mathrm{NH}_{4}}{ }^{+}$convertido, 4,25 g de $\mathrm{O}_{2}$ são consumidos, 0,16 g de novas células são formadas, 7,07 g de alcalinidade como $\mathrm{CaCO}_{3}$ são removidas e $0,08 \mathrm{~g}$ de carbono inorgânico é utilizado na formação de novas células. $\mathrm{Na}$ equação acima, a nitrificação é apresentada como a oxidação do íon amônio $\left(\mathrm{NH}_{4}{ }^{+}\right)$, contudo, Schmidt et al. (2003) reportam que o substrato mais provável para o processo de nitrificação é a amônia $\left(\mathrm{NH}_{3}\right)$.

Os coeficientes cinéticos utilizados para o dimensionamento da nitrificação em sistemas de lodos ativados são apresentados na Tabela 3.1.

Tabela 3.1 - Coeficientes cinéticos de nitrificação a $20^{\circ} \mathrm{C}$, em sistema de lodos ativados.

\begin{tabular}{cccc}
\hline Coeficientes Cinéticos & Unidade & Faixa & Valor Típico \\
\hline$\mu_{\mathrm{m}}$ & $\mathrm{d}^{-1}$ & $0,20-0,90$ & 0,75 \\
$\mathrm{~K}_{\mathrm{S}}$ & $\mathrm{g} \mathrm{N}-\mathrm{NH}_{4}^{+} / \mathrm{m}^{3}$ & $0,50-1,00$ & 0,74 \\
$\mathrm{Y}$ & $\mathrm{g} \mathrm{SSV} / \mathrm{g} \mathrm{N}^{-\mathrm{NH}_{4}}+$ & $0,10-0,15$ & 0,12 \\
$\mathrm{k}_{\mathrm{d}}$ & $\mathrm{d}^{-1}$ & $0,05-0,15$ & 0,08 \\
\hline
\end{tabular}

Fonte: Metcalf \& Eddy (2003)

As reações de nitrificação podem ser afetadas por vários fatores ambientais incluindo temperatura, $\mathrm{pH}$, alcalinidade, oxigênio dissolvido, concentração de matéria orgânica e nitrogênio, toxicidade, entre outros. Esses fatores podem ter uma ação direta na atividade enzimática e na velocidade de crescimento, ou indireta, na estrutura do biofilme, velocidade de difusão e solubilidade do oxigênio. 
A influência da temperatura sobre o valor da velocidade de crescimento específico máximo das nitrificantes $\left(\mu_{\mathrm{m}}\right)$ é grande, como comprovam os resultados de vários pesquisadores. Segundo van Haandel \& Marais (1999) o valor de $\mu_{\mathrm{m}}$ dobra quando a temperatura aumenta em $6^{\circ} \mathrm{C} \mathrm{a} 7^{\circ} \mathrm{C}$. Entretanto, estudos realizados por Leenen et al. (1997) sugerem que organismos imobilizados são menos sensíveis a mudanças de temperatura do que células em suspensão. A velocidade de consumo de oxigênio de células imobilizadas de Nitrobacter agilis a $10^{\circ} \mathrm{C}$ foi cerca de $70 \%$ da velocidade a $30^{\circ} \mathrm{C}$, enquanto que dos organismos em suspensão, o percentual foi de apenas $15 \%$.

A nitrificação é sensível ao pH do meio, sendo que as velocidades de reação decrescem significativamente a valores de $\mathrm{pH}$ abaixo de 6,8. As velocidades de nitrificação para pH na faixa de 5,8 a 6,0 chegam a ser $80 \%$ a $90 \%$ menores que as velocidades para pH igual a 7,0. Conforme relatado por Metcalf \& Eddy (2003), a faixa de pH ótima para a atividade nitrificante é de 7,5 a 8,0.

Com relação à toxicidade, os organismos nitrificantes são sensíveis a um amplo número de compostos orgânicos e inorgânicos, sendo que as concentrações inibitórias para eles são bem menores que para os organismos heterotróficos aeróbios. Dentre os compostos tóxicos incluem-se os solventes orgânicos, aminas, proteínas, compostos fenólicos, álcoois, cianetos, éteres, entre outros. Os metais também produzem efeito tóxico nas nitrificantes, sendo observada completa inibição da oxidação da amônia em concentrações de níquel, cromo e cobre da ordem de $0,25 \mathrm{mg} / 1,0,25 \mathrm{mg} / \mathrm{l}$ e $0,10 \mathrm{mg} / \mathrm{l}$, respectivamente (METCALF \& EDDY, 2003).

Amônia livre $\left(\mathrm{NH}_{3}\right)$ e ácido nítrico não ionizado $\left(\mathrm{HNO}_{2}\right)$ também podem ser tóxicos às nitrificantes. $\mathrm{O}$ efeito inibitório depende da concentração total das espécies de nitrogênio no meio, da temperatura e do pH. Segundo Metcalf \& Eddy (2003), a uma temperatura de $20^{\circ} \mathrm{C}$ e $\mathrm{pH}$ igual a 7,0 , concentrações de $\mathrm{N}^{-\mathrm{NH}_{4}}{ }^{+}$por volta de $100 \mathrm{mg} / \mathrm{l} \mathrm{e}$ $20 \mathrm{mg} / \mathrm{l}$ podem causar inibição, respectivamente, na oxidação de $\mathrm{N}-\mathrm{NH}_{4}{ }^{+}$e $\mathrm{N}-\mathrm{NO}_{2}{ }^{-}$. Nas mesmas condições, concentrações de $280 \mathrm{mg} / \mathrm{l}$ de $\mathrm{N}_{-} \mathrm{NO}_{2}{ }^{-}$podem inibir a oxidação de $\mathrm{N}-\mathrm{NO}_{2}^{-}$.

Em baixas concentrações de oxigênio dissolvido $(<0,50 \mathrm{mg} / \mathrm{l})$, em que a atividade nitrificante é muito baixa, o efeito inibitório é maior para as bactérias oxidadoras de nitrito do que para as oxidadoras de amônia. Nestas condições, pode ocorrer nitrificação incompleta e acúmulo de $\mathrm{N}^{-\mathrm{NO}_{2}}{ }^{-}$no meio (METCALF \& EDDY, 2003).

A oxidação da amônia a nitrito e nitrato por microrganismos 
quimiorganotróficos é denominada nitrificação heterotrófica. Esse fenômeno ocorre preferencialmente em condições não favoráveis a nitrificação autotrófica, como por exemplo, em ambientes acidificados. A nitrificação heterotrófica é encontrada no metabolismo de algas, fungos e bactérias e se comparada à nitrificação autotrófica, possui uma velocidade muito inferior de nitrificação, motivo pelo qual não é considerada no tratamento de despejos líquidos (SCHMIDT et al.,2003).

\subsubsection{Processo de desnitrificação}

A conversão biológica de compostos oxidados de nitrogênio como nitrito e nitrato em compostos mais reduzidos como óxido nítrico $(\mathrm{NO})$, óxido nitroso $\left(\mathrm{N}_{2} \mathrm{O}\right)$ e gás nitrogênio $\left(\mathrm{N}_{2}\right)$ é denominada desnitrificação. Em processos convencionais de tratamento de águas residuárias, a desnitrificação é processada por bactérias heterotróficas aeróbias facultativas, incluindo os gêneros Achromobacter, Acinetobacter, Agrobacterium, Alcaligenes, Arthrobacter, Bacillus, Chromobacterium, Corynebacterium, Flavobacterium, Hypomicrobium, Moraxella, Neisseria, Paracoccus, Propionibacterium, Pseudomonas, Rhizobium, Rhodopseudomonas, Spirillum, Vibrio, halobacterium e Methanomonas (METCALF \& EDDY, 2003).

Em revisão realizada por Colliver \& Stephenson (2000), relata-se a possibilidade de bactérias nitrificantes autotróficas atuarem como desnitrificantes, produzindo $\mathrm{N}_{2} \mathrm{O}$, $\mathrm{NO}$ ou $\mathrm{N}_{2}$. Entretanto, as velocidades de conversão por essa via são extremamente baixas quando comparadas às vias ditas convencionais de nitrificação e desnitrificação, não tendo papel significativo nos processos de tratamento de águas residuárias.

A desnitrificação pode ser considerada como um tipo de respiração anóxica. Elétrons originados de material orgânico, compostos reduzidos de enxofre, ou hidrogênio molecular são transferidos para compostos oxidados de nitrogênio ao invés do oxigênio, a fim de produzir energia para o metabolismo celular. As enzimas envolvidas na desnitrificação são a nitrato redutase, a nitrito redutase, a óxido nítrico redutase e finalmente a óxido nitroso redutase perfazendo a rota mostrada na Equação 3.10 (SCHMIDT et al., 2003).

$$
\mathrm{NO}_{3}^{-} \rightarrow \mathrm{NO}_{2}^{-} \rightarrow \mathrm{NO} \rightarrow \mathrm{N}_{2} \mathrm{O} \rightarrow \mathrm{N}_{2}
$$


Admitindo uma fórmula geral para material orgânico como doador de elétrons $\left(\mathrm{C}_{\mathrm{x}} \mathrm{H}_{\mathrm{y}} \mathrm{O}_{\mathrm{z}}\right)$, van Haandel \& Marais (1999) apresentam as seguintes equações para as reações de desnitrificação:

Oxidação:

$$
\mathrm{C}_{x} \mathrm{H}_{y} \mathrm{O}_{z}+(2 x-z) \mathrm{H}_{2} \mathrm{O} \rightarrow x \mathrm{CO}_{2}+(4 x+y-2 z) \mathrm{H}^{+}+(4 x+y-2 z) e^{-}
$$

Redução:

$$
e^{-}+\frac{6}{5} \mathrm{H}^{+}+\frac{1}{5} \mathrm{NO}_{3}^{-} \rightarrow \frac{1}{10} \mathrm{~N}_{2}+\frac{1}{5} \mathrm{H}_{2} \mathrm{O}
$$

Reação global:

$$
\begin{aligned}
C_{x} H_{y} O_{z} & +\left(\frac{4 x+y-2 z}{5}\right) H^{+}+\left(\frac{4 x+y-2 z}{5}\right) N O_{3}^{-} \rightarrow \\
& \rightarrow x C_{2}+\left(\frac{2 x+3 y-z}{5}\right) H_{2} O+\left(\frac{4 x+y-2 z}{10}\right) N_{2}
\end{aligned}
$$

Utilizando-se etanol $\left(\mathrm{C}_{2} \mathrm{H}_{5} \mathrm{OH}\right)$ como fonte de carbono para a desnitrificação, a Equação 3.13 fica:

$$
5 \mathrm{C}_{2} \mathrm{H}_{5} \mathrm{OH}+12 \mathrm{H}^{+}+12 \mathrm{NO}_{3}^{-} \rightarrow 10 \mathrm{CO}_{2}+21 \mathrm{H}_{2} \mathrm{O}+6 \mathrm{~N}_{2}
$$

Assim, para cada $1 \mathrm{~g}$ de $\mathrm{N}_{-} \mathrm{NO}_{3}{ }^{-}$removido tem-se $1,37 \mathrm{~g}$ de etanol consumido $(0,71 \mathrm{~g} \mathrm{C})$ e 3,57 $\mathrm{g}$ de alcalinidade como $\mathrm{CaCO}_{3}$ formados.

A velocidade de desnitrificação é dependente da natureza e concentração da fonte de carbono, sendo que os doadores de elétrons típicos são: 1) a matéria orgânica solúvel presente na água residuária; 2) a matéria orgânica solúvel produzida durante o decaimento endógeno celular; e 3) uma fonte externa de carbono tal como metanol, etanol ou ácido acético. Contudo, Foresti et al. (2006) ressaltam que compostos oriundos de processos anaeróbios tais como ácidos orgânicos, metano, álcoois, compostos reduzidos de enxofre, entre outros também podem ser utilizados como doadores de elétrons para a desnitrificação, principalmente em sistemas combinados anaeróbio-aeróbio.

Santos et al. (2004) estudaram a utilização de etanol, metanol e metano como 
doadores de elétrons para a desnitrificação em um reator em batelada, inoculado com lodo anaeróbio granulado. Comparando as velocidades de desnitrificação alcançadas para cada substrato utilizado, concluiu-se que o melhor doador de elétrons foi o etanol, com o qual alcançou-se velocidade de desnitrificação 2,4 e 7 vezes maior que as velocidades de desnitrificação alcançadas utilizando-se metanol e metano, respectivamente.

Cuba (2005) avaliou o potencial de uso do metano como doador de elétrons para a desnitrificação em reator anóxico horizontal de leito fixo. Para concentrações iniciais de $\mathrm{N}-\mathrm{NO}_{3}{ }^{-}$de $20 \mathrm{mg} / \mathrm{l}$ e $40 \mathrm{mg} / \mathrm{l}$ no substrato sintético, foi possível obter diminuição das concentrações iniciais em $85 \%$ e $50 \%$, respectivamente. No entanto, os altos níveis de redução de $\mathrm{N}^{-\mathrm{NO}_{3}}{ }^{-}$, obtidos sob condições limitantes de metano deram suporte à hipótese de que parte da remoção do nitrato foi realizada mediante a utilização de compostos reduzidos de enxofre ou nitrogênio, tais como $\mathrm{S}^{0}, \mathrm{HS}^{-}$ou $\mathrm{NH}_{4}^{+}$, provavelmente formados sob condições anóxicas, simultaneamente com o processo de desnitrificação.

O oxigênio pode causar inibição na desnitrificação pela repressão das enzimas redutoras de nitrato. Contudo, Metcalf \& Eddy (2003) ressaltam que a desnitrificação pode ocorrer na presença de baixas concentrações de oxigênio dissolvido $\left(0,5 \mathrm{mg} \mathrm{O}_{2} / \mathrm{l}\right)$. Isso porque a concentração de oxigênio no interior do floco ou biofilme pode ser menor que no meio líquido, promovendo a desnitrificação nesses locais.

Entre as condições ambientais mais importantes na desnitrificação estão a temperatura e o pH. van Haandel \& Marais (1999) relatam que a velocidade de desnitrificação é máxima para uma faixa de pH entre 7,0 e 7,5 e que para valores abaixo de 6,0 e acima de 8,5 há uma diminuição considerável na atividade desnitrificante. Observam também que a velocidade de desnitrificação aumenta com a temperatura até atingir um valor ótimo de $40^{\circ} \mathrm{C}$.

Para o dimensionamento da desnitrificação em sistemas de lodos ativados utiliza-se comumente a velocidade de desnitrificação específica, sendo que os valores típicos estão na faixa de 0,04 a $0,42 \mathrm{~g} \mathrm{~N}^{-N^{-}}{ }_{3} \cdot \mathrm{g} \mathrm{SSV}^{-1} \cdot \mathrm{d}^{-1}$ (METCALF \& EDDY, 2003). 


\subsection{NOVOS CONCEITOS E TECNOLOGIAS NA REMOÇÃO BIOLÓGICA DE NITROGÊNIO}

Nesta seção serão apresentados novos processos e tecnologias para a remoção de nitrogênio em águas residuárias, sendo que a maioria ainda está em fase de desenvolvimento, limitando-se em aplicações a escala de bancada e piloto.

\subsubsection{Nitrificação parcial}

A oxidação do nitrogênio amoniacal a nitrito (nitritação), sem a posterior oxidação a nitrato é denominada nitrificação parcial. A reação simplificada de nitritação é apresentada pela Equação 3.15.

$$
\mathrm{NH}_{4}^{+}+1,5 \mathrm{O}_{2} \rightarrow \mathrm{NO}_{2}^{-}+2 \mathrm{H}^{+}+\mathrm{H}_{2} \mathrm{O}
$$

A nitrificação parcial pode ser combinada com a desnitrificação convencional, ou seja, remoção do nitrogênio através da desnitrificação heterotrófica utilizando o nitrito como aceptor final de elétrons. O equacionamento simplificado da reação de desnitrificação, via nitrito, utilizando etanol $\left(\mathrm{C}_{2} \mathrm{H}_{5} \mathrm{OH}\right)$ como fonte de carbono é mostrado na Equação 3.16.

$$
\mathrm{C}_{2} \mathrm{H}_{5} \mathrm{OH}+4 \mathrm{H}^{+}+4 \mathrm{NO}_{2}^{-} \rightarrow 2 \mathrm{CO}_{2}+5 \mathrm{H}_{2} \mathrm{O}+2 \mathrm{~N}_{2}
$$

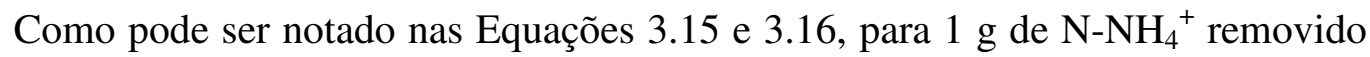
por meio da desnitrificação via nitrito, apenas $3,43 \mathrm{~g}$ de $\mathrm{O}_{2}$ e $0,82 \mathrm{~g}$ de etanol $(0,43 \mathrm{~g}$ de C) são consumidos, representando uma economia de $25 \%$ em aeração e $40 \%$ na dosagem de etanol, se comparado com o processo convencional de desnitrificação via nitrato.

Para se evitar a subseqüente oxidação do nitrito a nitrato no reator aeróbio, existem pelo menos dois possíveis mecanismos. O primeiro é utilizar a diferença entre as energias de ativação de oxidação do nitrogênio amoniacal $\left(68 \mathrm{~kJ}^{\mathrm{mol}}{ }^{-1}\right)$ e do nitrito $\left(44 \mathrm{~kJ} \mathrm{~mol}^{-1}\right)$ como ferramenta para promover o crescimento das oxidadoras de amônia e o segundo é suprimir o crescimento das oxidadoras de nitrito. 
Devido a maior energia de ativação necessária para a nitritação em relação a nitratação, a velocidade de crescimento das oxidadoras de amônia sofre maior influência com a temperatura. Segundo Khin \& Annachhatre (2004) a velocidade de crescimento específico máxima das oxidadoras de nitrito à $35^{\circ} \mathrm{C}$ é aproximadamente a metade que das oxidadoras de amônia $\left(0,5 \mathrm{~d}^{-1}\right.$ e $1,0 \mathrm{~d}^{-1}$, respectivamente). A partir desse conceito, o processo SHARON (single reactor system for high ammonia removal over nitrite) propõe a nitrificação parcial em um reator aeróbio de fluxo contínuo, sem retenção de biomassa, operando a uma temperatura acima de $26^{\circ} \mathrm{C}$. Nestas condições, quando o tempo de detenção hidráulica do reator for inferior a velocidade de duplicação das oxidadoras de nitrito, mas não das oxidadoras de amônia, os organismos nitrito redutores serão "lavados" do sistema promovendo a seleção de um meio estritamente amônio redutor (SCHMIDT et al., 2003).

A nitrificação parcial também pode ser atingida por meio do segundo mecanismo de prevenção da oxidação do nitrito. A baixas concentrações de oxigênio dissolvido $(<0,4 \mathrm{mg} / \mathrm{l})$ e excesso de $\mathrm{N}^{-\mathrm{NH}_{4}}{ }^{+}$, as oxidadoras de nitrito são incapazes de crescer e o nitrito se torna um produto final estável da nitrificação. A inibição das oxidadoras de nitrito pela amônia e uma baixa afinidade pelo oxigênio ou nitrito são sugeridas como possíveis explicações da inibição da nitratação, contudo, ainda não se conhece mecanismos que evidenciem essas hipóteses (SCHMIDT et al., 2003). Devido à dificuldade encontrada em se controlar estequiometricamente a concentração de oxigênio dentro dos reatores aeróbios, este mecanismo de nitrificação parcial ainda não foi aplicado em escala real.

Daniel (2005) estudou a remoção de nitrogênio via nitrito em reator operado em bateladas seqüenciais contendo biomassa imobilizada e aeração intermitente, ocorrendo a nitrificação parcial a nitrito nas etapas aeradas, com oxigênio dissolvido controlado entre 2,0 e 2,5 mg/l, e desnitrificação nas etapas anóxicas. O sistema foi alimentado com substrato sintético com concentração de nitrogênio amoniacal de 125, 250, 500 e 40 $\mathrm{mg} / \mathrm{l}$. Ao longo do período operacional, o nitrogênio na forma de nitrito tornou-se a forma oxidada predominante, mantendo esta condição em todas as etapas de operação do reator, mesmo alterando a concentração de oxigênio dissolvido, prolongando o período de aeração e reduzindo a concentração de amônia livre. Constatou-se, portanto, a possibilidade de obtenção de processo estável de nitrificação parcial e desnitrificação em reator operado em bateladas seqüenciais e aeração intermitente.

Devido à dificuldade encontrada em se controlar os vários parâmetros 
operacionais envolvidos no processo (temperatura, $\mathrm{pH}$, tempo de retenção hidráulica, concentração de substrato e oxigênio dissolvido), o processo de nitrificação parcial ainda não é aplicado em escala real.

\subsubsection{Processo ANAMMOX}

O processo ANAMMOX (anaerobic ammonium oxidation) consiste na desnitrificação do nitrito utilizando o íon amônio como doador de elétrons, conforme reação simplificada abaixo:

$$
\mathrm{NH}_{4}^{+}+\mathrm{NO}_{2}^{-} \rightarrow \mathrm{N}_{2}+2 \mathrm{H}_{2} \mathrm{O}
$$

Considerando que a biomassa anaeróbia oxidadora de amônio possa ser representada pela fórmula empírica $\mathrm{CH}_{2} \mathrm{O}_{0,5} \mathrm{~N}_{0,15}$, Schmidt et al. (2002) sugerem a equação empírica seguinte:

$$
\begin{aligned}
& \mathrm{NH}_{4}^{+}+1,32 \mathrm{NO}_{2}^{-}+0,066 \mathrm{HCO}_{3}^{-}+0,13 \mathrm{H}^{+} \rightarrow \\
& \quad \rightarrow 1,02 \mathrm{~N}_{2}+0,26 \mathrm{NO}_{3}^{-}+0,066 \mathrm{CH}_{2} \mathrm{O}_{0,5} \mathrm{~N}_{0,15}+2,03 \mathrm{H}_{2} \mathrm{O}
\end{aligned}
$$

Como pode ser visto na Equação 3.18, o principal produto da oxidação anaeróbia da amônia é o gás nitrogêno $\left(\mathrm{N}_{2}\right)$, contudo cerca de $10 \%$ do nitrogênio

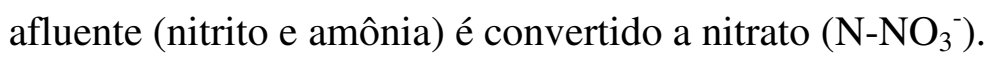

Como o processo ANAMMOX necessita ser precedido de uma etapa de nitrificação parcial, a idéia de se combinar o processo SHARON com o ANAMMOX é sugerida por vários pesquisadores. A água residuária contendo nitrogênio na forma amoniacal é oxidada no reator SHARON a nitrito, utilizando apenas 50\% da amônia afluente, conforme Equação 3.19, e posteriormente encaminhada para o reator ANAMMOX.

$$
\mathrm{NH}_{4}^{+}+0,75 \mathrm{O}_{2} \rightarrow 0,5 \mathrm{NH}_{4}^{+}+0,5 \mathrm{NO}_{2}^{-}+\mathrm{H}^{+}+0,5 \mathrm{H}_{2} \mathrm{O}
$$

Para se atingir os parâmetros ideais para o processo ANAMMOX $\left(\mathrm{N}^{-\mathrm{NO}_{2}}{ }^{-} / \mathrm{N}-\right.$ 
$\mathrm{NH}_{4}{ }^{+} \approx 1$ ), o reator SHARON é operado com pH e concentração de oxigênio dissolvido mais baixos, inibindo a ação das oxidadoras de amônia e conseqüentemente a nitrificação total do nitrogênio afluente (KHIN \& ANNACHHATRE, 2004; SCHMIDT et al., 2003).

Comparado com a remoção convencional de nitrogênio (nitrificação e desnitrificação via nitrato), a combinação dos processos SHARON e ANAMMOX representam economia de $50 \%$ nos requisitos de oxigênio e $100 \%$ na dosagem de fonte externa de carbono. Contudo, a aplicação deste processo ainda se restringe a escalas de laboratório e piloto, necessitando maiores pesquisas na área e desenvolvimento de novas tecnologias para o emprego do processo em escala real.

\subsubsection{Processo CANON}

O conceito do processo CANON (completely autotrophic nitrogen removal over nitrite) consiste na combinação dos processos de nitrificação parcial e oxidação anaeróbia do nitrogênio na forma amoniacal (ANAMMOX) em um único reator aerado.

O processo CANON se baseia no fato de que sob condições limitantes de oxigênio, uma cultura conjunta de bactérias aeróbias e anaeróbias oxidadoras de amônia pode se estabelecer. A cooperação entre estes dois diferentes grupos microbianos é de vital importância para o processo CANON. As bactérias nitrificantes oxidam a amônia a nitrito, consomem oxigênio e então criam um ambiente anóxico que o processo ANAMMOX necessita (KHIN \& ANNACHHATRE, 2004; SCHMIDT et al., 2003).

As reações estequiométricas envolvidas no processo CANON são apresentadas pelas equações seguintes:

Nitrificação parcial:

$\mathrm{NH}_{4}^{+}+1,5 \mathrm{O}_{2} \rightarrow \mathrm{NO}_{2}^{-}+2 \mathrm{H}^{+}+\mathrm{H}_{2} \mathrm{O}$

ANAMOX:

$\mathrm{NH}_{4}^{+}+1,3 \mathrm{NO}_{2}^{-} \rightarrow 1,02 \mathrm{~N}_{2}+0,26 \mathrm{NO}_{3}^{-}+2 \mathrm{H}_{2} \mathrm{O}$ 
Reação global:

$$
\mathrm{NH}_{4}^{+}+0,85 \mathrm{O}_{2} \rightarrow 0,435 \mathrm{~N}_{2}+0,13 \mathrm{NO}_{3}^{-}+1,3 \mathrm{H}_{2} \mathrm{O}+1,4 \mathrm{H}^{+}
$$

Embora esteja em fase inicial de desenvolvimento, restringido-se a reatores de bancada, o processo CANON é opção econômica e eficiente para o futuro do tratamento de águas residuárias, principalmente aquelas ricas em nitrogênio amoniacal e pobres em material orgânico. Como o processo é completamente autotrófico não há a necessidade de se aplicar uma fonte externa de carbono e o consumo de oxigênio é cerca de $65 \%$ menor que no processo convencional de remoção de nitrogênio.

\subsubsection{Processo $\mathrm{NO}_{\mathrm{x}}$}

O controle e a estimulação da atividade desnitrificante das bactérias similares ao gênero Nitrossomonas pela adição de óxidos de nitrogênio oferece uma nova possibilidade de tratamento de águas residuárias. $\mathrm{Na}$ presença de $\mathrm{NO}_{\mathrm{x}}$, essas bactérias nitrificam e desnitrificam simultaneamente em ambiente completamente aeróbio, tendo $\mathrm{N}_{2}$ como principal produto. Schmidt et al. (2003) apresentam as seguintes reações estequiométricas de conversão:

Nitrificação:

$3 \mathrm{NH}_{4}^{+}+3 \mathrm{O}_{2} \rightarrow \mathrm{N}_{2}+4 \mathrm{H}_{2} \mathrm{O}+\mathrm{NO}_{2}^{-}+4 \mathrm{H}^{+}$

Desnitrificação (utilizando etanol como fonte de carbono):

$$
\mathrm{NO}_{2}^{-}+\mathrm{H}^{+}+0,25 \mathrm{C}_{2} \mathrm{H}_{5} \mathrm{OH} \rightarrow 0,5 \mathrm{~N}_{2}+0,5 \mathrm{CO}_{2}+1,25 \mathrm{H}_{2} \mathrm{O}
$$

Reação global:

$$
3 \mathrm{NH}_{4}^{+}+3 \mathrm{O}_{2}+0,25 \mathrm{C}_{2} \mathrm{H}_{5} \mathrm{OH} \rightarrow 1,5 \mathrm{~N}_{2}+3 \mathrm{H}^{+}+0,5 \mathrm{CO}_{2}+5,25 \mathrm{H}_{2} \mathrm{O}
$$

Como visto nas Equação 3.23 a 3.25, apenas $40 \%$ da amônia é convertida a nitrito acarretando numa demanda de oxigênio $50 \%$ menor que para a oxidação completa, além da posterior desnitrificação necessitar de menor quantidade de matéria orgânica representada nas equações acima por etanol $\left(\mathrm{C}_{2} \mathrm{H}_{5} \mathrm{OH}\right)$. 
A dosagem de $\mathrm{NO}_{\mathrm{x}}\left(\mathrm{NO} / \mathrm{NO}_{2}\right)$ objetivando a indução da atividade desnitrificante pelas oxidadoras de amônia deve ser feita em quantidades traço, na razão de 0,2 a 1,0 g de $\mathrm{NO}_{2}$ por $1 \mathrm{~kg}$ de $\mathrm{NH}_{4}{ }^{+}$(SCHMIDT et al., 2003).

$\mathrm{O}$ processo $\mathrm{NO}_{\mathrm{x}}$ oferece a possibilidade de ser integrado a plantas já existentes de tratamento de águas residuárias com poucas modificações e mínimo investimento.

\subsubsection{Processo OLAND}

O processo OLAND (oxygen-limited nitrification and denitrification) baseia-se na remoção direta do nitrogênio em condições limites de oxigenação por meio da ação nitrificante e desnitrificante das bactérias do gênero Nitrossomonas. Segundo Kuai \& Verstraete (1998), quando o oxigênio é fornecido de forma estequiométrica, a nitrificação ocorre até nitrito e devido à escassez de aceptores de elétrons, o nitrito formado é reduzido a $\mathrm{N}_{2}$ para oxidar o restante do nitrogênio amoniacal. A estequiometria do processo é descrita a seguir:

Nitrificação:

$0,5 \mathrm{NH}_{4}^{+}+0,75 \mathrm{O}_{2} \rightarrow 0,5 \mathrm{NO}_{2}^{-}+0,5 \mathrm{H}_{2} \mathrm{O}+\mathrm{H}^{+}$

Desnitrificação:

$0,5 \mathrm{NH}_{4}^{+}+0,5 \mathrm{NO}_{2}^{-} \rightarrow 0,5 \mathrm{~N}_{2}+\mathrm{H}_{2} \mathrm{O}$

Reação global:

$\mathrm{NH}_{4}^{+}+0,75 \mathrm{O}_{2} \rightarrow 0,5 \mathrm{~N}_{2}+1,5 \mathrm{H}_{2} \mathrm{O}+\mathrm{H}^{+}$

Em comparação ao processo convencional de nitrificação e desnitrificação, o processo OLAND fornece uma economia de 62,5\% de oxigênio e por ser um processo totalmente autotrófico não requer adição de fonte externa de carbono orgânico. Entretanto, o controle de concentrações muito baixas de oxigênio dissolvido com propósito de limitar a velocidade de respiração celular é muito difícil, principalmente em reatores de larga escala, o que gera uma dificuldade na implantação do processo. 


\subsection{BIOMASSA IMOBILIZADA EM SUPORTE INERTE}

Uma alternativa que vem sendo estudada para aprimorar a configuração dos reatores é a utilização de biomassa imobilizada em suporte inerte. Neste caso ocorre a formação de biofilme aderido à superfície do suporte, com predomínio deste sobre culturas livres em suspensão, havendo a criação de micro-ambientes especiais pela interação entre as espécies, favorecendo o conjunto como um todo e garantindo grande estabilidade das colônias. Além disso, a utilização de suportes inertes assegura a retenção da biomassa no reator e propicia a operação com tempo de retenção celular muito elevado, aumentando a eficiência do reator.

O emprego de um suporte para imobilização da biomassa envolve novas questões relacionadas ao desempenho do reator, uma vez que poderão surgir resistências à transferência de massa, inerentes a processos que envolvem duas fases distintas, no caso sólida e líquida. Desta forma, a eficiência de reatores contendo células imobilizadas também está diretamente relacionada com os fluxos de massa entre as fases líquida e sólida, os quais podem ser limitantes do processo de conversão e causar considerável decréscimo da velocidade global das reações.

Portanto, a escolha do material adequado a ser utilizado como suporte é de fundamental importância para a formação do biofilme e retenção da biomassa no interior do reator. A aderência depende das propriedades físico-químicas do suporte sendo que, de acordo com Huysman et al. (1983), as superfícies porosas e rugosas são mais propícias do que as superfícies lisas e, ainda, o tamanho e o número de poros também influenciará no resultado final. As características da água residuária devem ser consideradas, uma vez que poderá interagir com o suporte, além de interferir diretamente na adesão microbiana. Outro aspecto que deve ser considerado é que a condição hidrodinâmica do sistema deve propiciar a manutenção do biofilme, pois em situações hidrodinâmicas críticas o biofilme pode se desprender do suporte e conseqüentemente ser arrastado do reator (ALVES, 1999; HUYSMAN et al., 1983; GIJZEN et al., 1988; WIRTZ \& DAGUE, 1997; VARESCHE et al., 1997; RATUSZNEI et al., 2000).

Entre as principais vantagens da utilização de reatores com biomassa imobilizada, segundo Bryers \& Characklis (1990), estão: 1) aumento da concentração de biomassa no reator; 2) aumento das velocidades globais de conversão dos substratos, devido às altas concentrações de biomassa; 3) o reator pode ser operado 
independentemente da velocidade de crescimento dos microrganismos; 4) redução no volume dos reatores; 5) redução na susceptibilidade a choques ou transiente, e 6) a possibilidade de eliminação dos estágios de clarificação/separação. Como desvantagem dos reatores de biofilme fixo está a falta de mecanismos efetivos para controle da espessura do biofilme, o que pode contribuir para limitações à transferência de massa e obstrução do leito.

\subsection{REMOÇ̃̃o DE MATÉRIA ORGÂNICA E NITROGÊNIO DE ÁGUAS RESIDUÁRIAS INDUSTRIAIS}

Embora o desenvolvimento de novos processos e tecnologias para a remoção de nitrogênio de águas residuárias industriais tenha se intensificado na última década, os processos convencionais de tratamento por lodos ativados ainda são os mais utilizados. Metcalf \& Eddy (2003) propõem a utilização de reatores de lodos ativados com zonas pré ou pós-anóxicas para a remoção de nitrogênio, sendo que a biomassa é comum para ambos os ambientes. Na Figura 3.2 são apresentados os fluxogramas básicos dos sistemas convencionais para remoção de nitrogênio de águas residuárias industriais.

Segundo Metcalf \& Eddy (2003), o sistema composto de reator pré-anóxico é recomendado para águas residuárias com alta relação DQO/N, assim, parte do carbono orgânico afluente é utilizado como doador de elétrons na desnitrificação, economizando dosagens posteriores de fonte de carbono. Para águas residuárias com baixa relação DQO/N em que a dosagem externa de carbono orgânico seria inevitável é recomendado o sistema pós-anóxico. O sistema Bardenpho é basicamente a junção dos dois primeiros sistemas, pré e pós-anóxico, seguido de uma zona aeróbia responsável pela remoção da DQO remanescente da dosagem de carbono orgânico na segunda zona anóxica. Esse sistema demanda grande área de implantação e alto consumo de energia, sendo sugerido apenas quando se requer um efluente com baixíssima concentração de nitrogênio total. 
a) Pré-anóxico

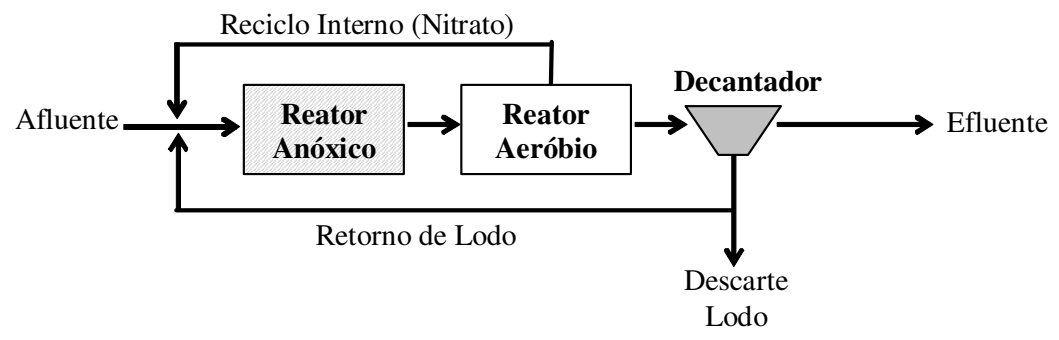

b) Pós-anóxico

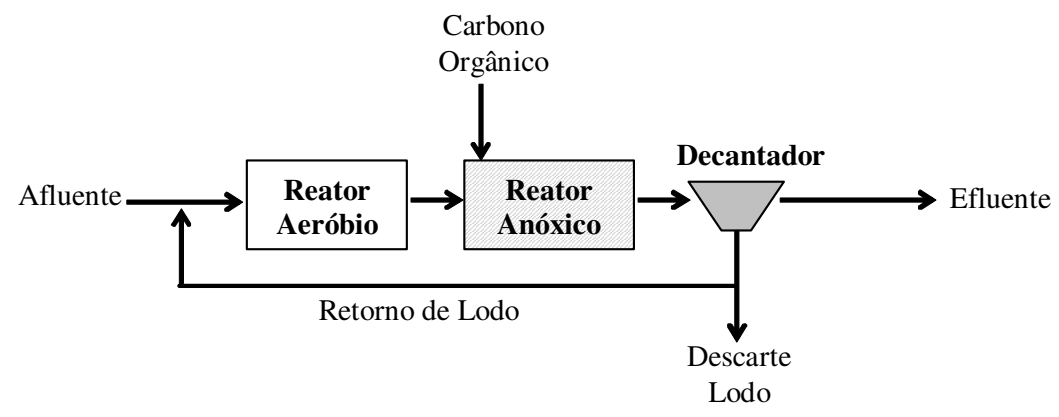

c) Bardenpho

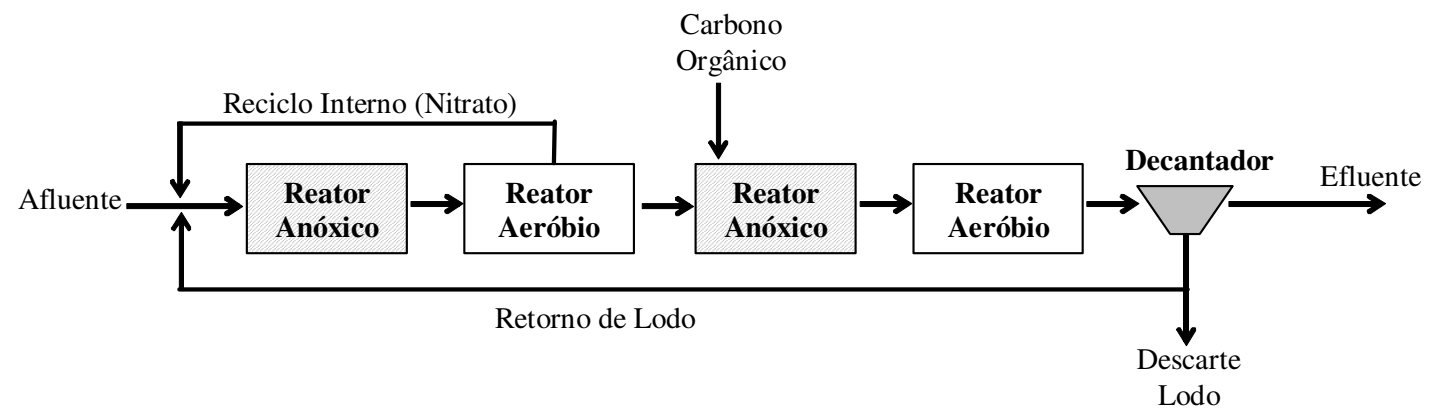

Figura 3.2 - Fluxograma simplificado dos sistemas de tratamento convencionais para remoção de nitrogênio (METCALF \& EDDY, 2003).

A influência da relação DQO/N na remoção biológica de nitrogênio em sistema convencional de lodos ativados pré-anóxico, tratando água residuária industrial com alta concentração de nitrogênio amoniacal, 4000 a $6000 \mathrm{mg} \mathrm{N}-\mathrm{NH}_{4}{ }^{+} / \mathrm{L}$, foi estudada por Carrera et al. (2004). Segundo os autores, a nitrificação é fortemente influenciada pela competição estabelecida entre os microrganismos heterotróficos e autotróficos e essa competição depende da relação $\mathrm{DQO} / \mathrm{N}$ da água residuária. Relações $\mathrm{DQO} / \mathrm{N}$ afluente entre 0,71 e $3,4 \mathrm{~g} \mathrm{DQO.g} \mathrm{N}^{-1}$ foram testadas a $25^{\circ} \mathrm{C}$ para várias cargas de nitrogênio, observando-se uma queda exponencial na velocidade de nitrificação quando a relação

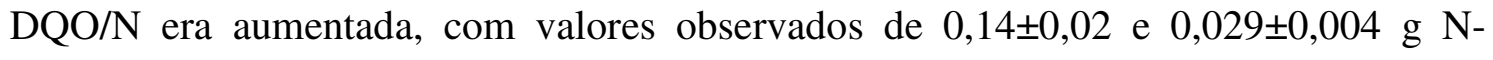
$\mathrm{NH}_{4}{ }^{+} \cdot \mathrm{g} \mathrm{SSV}^{-1} \cdot \mathrm{d}^{-1}$, respectivamente. 
Chen et al. (2003a) operaram um sistema convencional de lodos ativados préanóxico tratando água residuária de indústria EPTO (electronics and photonics technology office) com DQO e NTK variando de 500 a 1500 mg/l e de 100 a 250 mg/l, respectivamente. Com tempo de detenção hidráulica de 4,25 dias, razão de recirculação igual a 3 e idade do lodo mantida na faixa de 20 a 25 dias, as eficiências médias de remoção alcançadas foram de 94\% para DQO, 90\% para NTK (nitrogênio total Kjeldahl) e $81 \%$ para NT (nitrogênio total).

Em outro trabalho, Chen et al. (2003b) estudaram a remoção de DQO e nitrogênio de água residuária de indústria EPTO em um sistema MBR (membrane bioreactor). A planta piloto consistia em um sistema de lodos ativados pré-anóxico com a etapa de separação sólido/líquido sendo promovida por um sistema de ultrafiltração. As eficiências alcançadas na remoção de DQO, NTK e NT foram de 94\%, 90\% e 75\%, respectivamente, com tempo de retenção hidráulica de 1,7 dia e razão de recirculação igual a 3. Comparado com o processo convencional, o processo MBR manteve uma boa eficiência de remoção apesar do menor tempo de detenção hidráulica aplicado. Isso foi atribuído a alta concentração de biomassa dentro dos reatores (8 g SST/l) propiciada pelo processo de separação por membrana.

Carrera et al. (2003) operaram um sistema de lodos ativados tratando água residuária industrial com cerca de $5000 \mathrm{mg} \mathrm{N}-\mathrm{NH}_{4}{ }^{+} / 1$ e DQO praticamente zero. O sistema era composto de dois reatores independentes operados em série, o primeiro aeróbio promovendo a nitrificação e o segundo anóxico promovendo a desnitrificação, sendo que cada reator possuía seu próprio decantador, conforme fluxograma da Figura 3.3. As velocidades máximas de nitrificação alcançadas foram de $0,10,0,21$, e $0,37 \mathrm{~g} \mathrm{~N}$ $\mathrm{NH}_{4}{ }^{+} . \mathrm{g} \mathrm{SSV}^{-1} . \mathrm{d}^{-1}$, respectivamente, para temperaturas de $15^{\circ} \mathrm{C}, 20^{\circ} \mathrm{C}$ e $25^{\circ} \mathrm{C}$. Para a desnitrificação foram testadas duas fontes externas de carbono, etanol e uma solução contendo $60 \%$ de metanol, $10 \%$ de acetona e $10 \%$ de álcool isopropílico. A máxima velocidade de desnitrificação atingida com etanol a $20^{\circ} \mathrm{C}\left(0,64 \mathrm{~g} \mathrm{~N}-\mathrm{NO}_{\mathrm{x}}{ }^{-} \cdot \mathrm{g} \mathrm{SSV}^{-1} \cdot \mathrm{d}^{-1}\right)$ foi cerca de 6 vezes maior que a atingida com a solução de metanol $\left(0,11 \mathrm{~g} \mathrm{~N}-\mathrm{NO}_{\mathrm{x}}{ }^{-} \cdot \mathrm{g} \mathrm{SSV}^{-}\right.$ $\left.{ }^{1} . d^{-1}\right)$. 


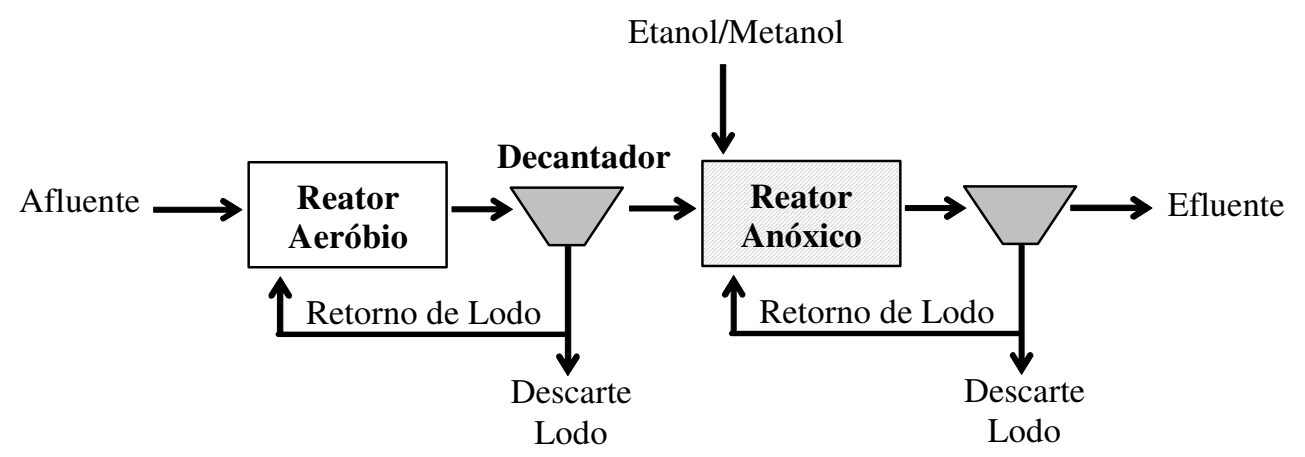

Figura 3.3 - Fluxograma simplificado do sistema de lodos ativados para remoção de nitrogênio com reatores aeróbio e anóxico independentes (CARRERA et al., 2003).

Embora a maioria dos processos propostos ainda esteja em escala piloto, há uma tendência na utilização de processos combinados anaeróbio-aeróbio para o tratamento de águas residuárias industriais contendo materiais orgânicos complexos e nitrogenados. Vários aspectos são responsáveis por esta escolha, podendo ser citados a menor área requerida para implantação da estação e menor custo de operação.

CHUI et al. (1996) propuseram um reator vertical de leito fixo de fluxo ascendente parcialmente aerado. O reator possuía uma zona aerada no topo da coluna onde se processava a nitrificação e a desnitrificação e uma zona não aerada na base da coluna que funcionava como um reator anaeróbio, eliminando grande parte da matéria orgânica. O suporte de imobilização da biomassa utilizado, anéis porosos de vidro, permitia que organismos desnitrificantes se fixassem nos seus vazios, tornando possível nitrificar e desnitrificar em um mesmo ambiente. Aplicando-se uma concentração afluente de 250 mg/l de NTK notou-se que remoções significativas de nitrogênio, acima de $65 \%$, só eram atingidas para tempos de detenção hidráulica superiores a 12 horas. Observou-se também que, para esse sistema, a relação DQO/N mais adequada para a remoção de nitrogênio era por volta de 5 .

ROS \& VRTOVSEK (1998) estudaram um reator vertical combinado anaeróbioanóxico-aeróbio, de fluxo ascendente, como unidade de tratamento de água residuária de indústria farmacêutica com DQO igual a $200 \mathrm{mg} / \mathrm{l}$ e NTK igual a $80 \mathrm{mg} / \mathrm{l}$. A primeira zona, anaeróbia, consistia de um reator de manta de lodo e as duas zonas subseqüentes, anóxica e aeróbia, de reator de leito fixo utilizando anéis de plásticos como suporte da biomassa. O reator anaeróbio tinha apenas a função de transformar a matéria orgânica complexa a compostos facilmente biodegradáveis que, posteriormente, seriam utilizados na desnitrificação. Assim, constatou-se que um tempo de detenção hidráulica de uma 
hora na zona anaeróbia era suficiente para acidificar toda a matéria orgânica.

Um reator SBR (sequencing batch reactor) como unidade de pós-tratamento de efluente de reator UASB, aplicado ao tratamento de água residuária de indústria alimentícia com DQO e NTK médios de 1500 e 630 mg/l, respectivamente, foi estudado por Villaverde et al. (2000). O reator SBR foi operado, visando remoção total do nitrogênio, com as seguintes etapas: 1) enchimento; 2) aeração intermitente; 3) decantação; e 4) esvaziamento (retirada do efleunte tratado). Por meio da aeração intermitente, etapas aeróbias e anóxicas se intercalaram durante o período reacional, favorecendo os processos de nitrificação e desnitrificação, respectivamente. Segundo os autores, o melhor resultado foi obtido com intervalos aeração/repouso de 6/12 minutos, tempo de ciclo de 40 horas e idade do lodo de 17 dias, alcançando remoções de DQO, NTK e NT de $90 \%, 98 \%$ e $79 \%$, respectivamente.

Lacalle et al. (2001) operaram sistema combinado anaeróbio-aeróbio aplicado ao tratamento de água residuária industrial com alta carga de matéria orgânica e nitrogênio, $10.400 \mathrm{mg} / \mathrm{l}$ de DQO e $790 \mathrm{mg} / \mathrm{l}$ de NTK. O sistema consistia de um reator UASB (upflow anaerobic sludge blanket) conectado em série a um reator UBAF (upflow biological aerated filter), tendo uma linha de recirculação do efluente do UBAF para o UASB. Atingiu-se, com tempo de detenção hidráulica de 3,3 dias para o reator UASB, 1,3 dia para o reator ABAF e razão de recirculação em 6,7, a remoção de $98 \%$ de matéria orgânica e de nitrogênio amoniacal e $91 \%$ de nitrogênio total.

\subsection{CONSIDERAÇÕES FINAIS}

Os sistemas biológicos combinados, anaeróbio-aeróbio, apresentam-se como uma alternativa promissora no tratamento de águas residuárias industriais, principalmente pela disponibilidade de se adequar o tratamento às características específicas de cada efluente da fábrica, englobando tanto a remoção de material orgânico quanto de nutrientes. O mesmo pode ser afirmado para os reatores de leito fixo, os quais possuem alta concentração de biomassa e alto tempo de retenção celular, propiciando a construção de sistemas de tratamento mais compactos e de alto desempenho.

A otimização em processos contínuos pode requerer elevados tempos de detenção hidráulica, sistemas de recirculação, decantadores secundários, além de 
elevado consumo de energia. $\mathrm{O}$ excesso de lodo formado durante o tratamento biológico secundário pode gerar um custo adicional de até $60 \%$ do custo total de uma unidade em operação, sendo necessário o desenvolvimento de novas configurações para reduzir a concentração de biomassa produzida (CALLADO, 2001).

Uma das alternativas para a redução da velocidade de crescimento celular é o aumento da concentração inicial de biomassa no sistema, fazendo com que o substrato seja fator limitante nos processos de produção e manutenção celular. Essa condição pode ser alcançada por meio de sistemas de células imobilizadas, nos quais tem sido observado um crescimento regulado de biomassa.

Neste contexto, o desenvolvimento de um sistema compacto que possa operar como única fonte de tratamento de água residuária industrial, tanto na remoção de matéria orgânica quanto na remoção de nitrogênio, com baixo consumo de energia e baixa formação de lodo, é de grande interesse para a maioria das indústrias, principalmente para as alimentícias. 



\section{Material e Métodos}

\subsection{DESCRIÇÃO GERAL DOS EXPERIMENTOS}

O trabalho de doutorado objetivou estudar o comportamento de um reator vertical de leito fixo no tratamento de água residuária industrial proveniente da fábrica da Ajinomoto Biolatina Indústria e Comércio Ltda, Valparaíso, SP. Para tanto, a fase experimental foi dividida em quatro etapas. Na primeira, variando-se o tempo de detenção hidráulica, avaliou-se a melhor condição operacional do reator vertical de leito fixo operando unicamente em condição anaeróbia. Posteriormente, na segunda etapa, objetivando-se a nitrificação do nitrogênio efluente do reator anaeróbio, transformou-se o reator anaeróbio em um reator combinado anaeróbio-aeróbio vertical de leito e avaliou-se a eficiência do sistema na remoção de matéria orgânica e nitrificação. Na terceira etapa, os módulos anaeróbios e aeróbios foram separados em dois reatores distintos e verificou-se o desempenho do sistema operando com os reatores anaeróbio e aeróbio em série. Por fim, na quarta etapa, os módulos anaeróbios e aeróbios foram reacoplados e variando-se a vazão de recirculação interna de efluente tratado para a zona anaeróbia do reator, avaliou-se a eficiência do sistema na remoção do nitrogênio total afluente.

Ao final dos experimentos, a biomassa aderida nos suportes dispostos ao longo do reator, tanto anaeróbia quanto aeróbia, foi quantificada e submetida a exames microbiológicos. Essas amostras de biomassa representavam apenas a última etapa de operação do reator combinado anaeróbio-aeróbio vertical de leito fixo, considerada a etapa mais importante dos experimentos. 


\subsection{REATOR EM ESCALA DE BANCADA}

A investigação experimental foi realizada nas dependências fabris da Ajinomoto Biolatina Indústria e Comércio Ltda. localizada em Valparaiso, São Paulo. A indústria foi instalada em maio de 1997 e faz parte da divisão de nutrição animal do grupo Ajinomoto, na qual se produz Lisina, aminoácido essencial para a nutrição de aves e suínos.

O aminoácido Lisina é produzido por meio da fermentação aeróbia da sacarose, tendo como principal matéria prima o açúcar de cana. O fluxograma simplificado da produção de Lisina na fábrica da Ajinomoto em Valparaíso é apresentado na Figura 4.1.

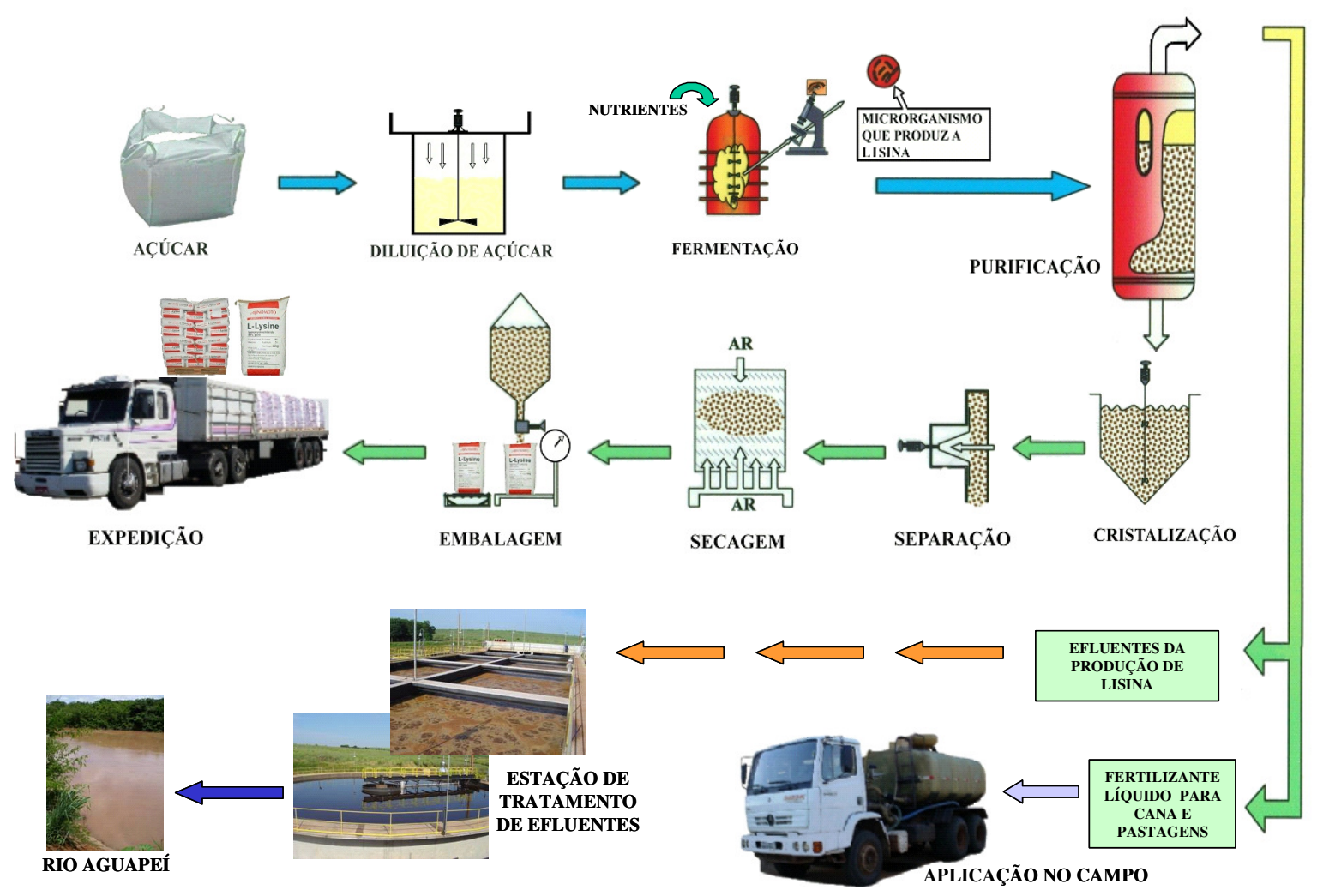

Figura 4.1 - Fluxograma da produção de Lisina na fábrica da Ajinomoto, Valparaíso,

SP.

Objetivando estudar uma nova concepção de reator biológico como única etapa de tratamento para os efluentes gerados no processo de purificação da Lisina, projetouse um reator combinado anaeróbio-aeróbio vertical de leito fixo em escala de bancada, com volume total de 35,9 litros, constituído de cinco partes moduladas: câmara de 
alimentação, leito com suporte de argila expandida, leito com espuma de poliuretano, câmara de aeração e câmara de saída. A foto da instalação experimental é apresentada na Figura 4.2 e o desenho dimensional do reator é mostrado na Figura 4.3.

Todas as partes do reator foram construídas com tubos de acrílico de $190 \mathrm{~mm}$ de diâmetro interno e $5 \mathrm{~mm}$ de espessura unidas através de flanges com anéis de borracha para vedação. O flange inferior dos módulos era constituído de uma chapa de acrílico de $10 \mathrm{~mm}$ de espessura com $240 \mathrm{~mm}$ de diâmetro colada de topo no tubo, contendo vários furos centrais para a contenção dos suportes e escoamento do fluido. O flange superior, também de espessura $10 \mathrm{~mm}$, consistia em um anel de acrílico de $200 \mathrm{~mm}$ de diâmetro interno e $240 \mathrm{~mm}$ de diâmetro externo colado na parede do tubo.

A câmara de alimentação possuía altura de $100 \mathrm{~mm}$ e na parede do módulo localizava-se a entrada de água residuária, que era direcionada para o centro do reator por um tubo de PVC de $1 / 2$ ". Nesta tubulação estavam acoplados um registro tipo globo de $1 / 2$ " e, a este, uma bomba dosadora tipo diafragma Milton Roy modelo P741-156 HV, com capacidade de recalcar uma faixa de vazão de 0 a 2,2 1/h. A extremidade inferior do módulo era vedada com um flange cego de acrílico, contendo uma válvula central de 1/2" tipo globo, para uma eventual descarga de fundo.

O leito com suporte de argila expandida foi construído com $200 \mathrm{~mm}$ de altura. $\mathrm{Na}$ parede do módulo localizava-se a entrada da recirculação de efluente que era direcionada para o centro do reator por um tubo de cobre de $3 \mathrm{~mm}$ de diâmetro. A recirculação também era promovida por uma bomba dosadora tipo diafragma Milton Roy modelo P741-156HV, com capacidade de recalcar uma faixa de vazão de 0 a 7,5 $1 / \mathrm{h}$.

Os leitos com suporte de espuma de poliuretano também possuíam altura de 200 mm. Um espigão de $3 / 8$ " localizado na parede dos módulos e vedado por uma mangueira de silicone era utilizado como ponto de coleta de amostra.

A câmara de aeração possuía $100 \mathrm{~mm}$ de altura. A entrada de ar localizava-se na parte central da parede do módulo e possuía um tubo de cobre de $3 \mathrm{~mm}$ de diâmetro com uma pedra porosa em sua extremidade, fixada no centro do reator. A aeração era suprida por uma linha de ar de processo da própria fábrica da Ajinomoto, tendo um filtro de ar com regulador de pressão acoplado. Para o controle da vazão de ar, também foi acoplado um registro de agulha de 1/4" na entrada do reator. Para coleta de amostra, o módulo também possuía um espigão de $3 / 8$ " vedado com uma mangueira de silicone, 
localizado na outra extremidade da parede do tubo.

Com altura de $100 \mathrm{~mm}$, a câmara de saída possuía um tubo de PVC de 1/2" acoplado em sua parede que coletava o efluente tratado no centro do reator e direcionava-o para um tanque de armazenamento.

Durante todo o experimento, o reator foi operado dentro de uma estufa com controle automático de temperatura mantida em $30 \pm 1^{\circ} \mathrm{C}$.

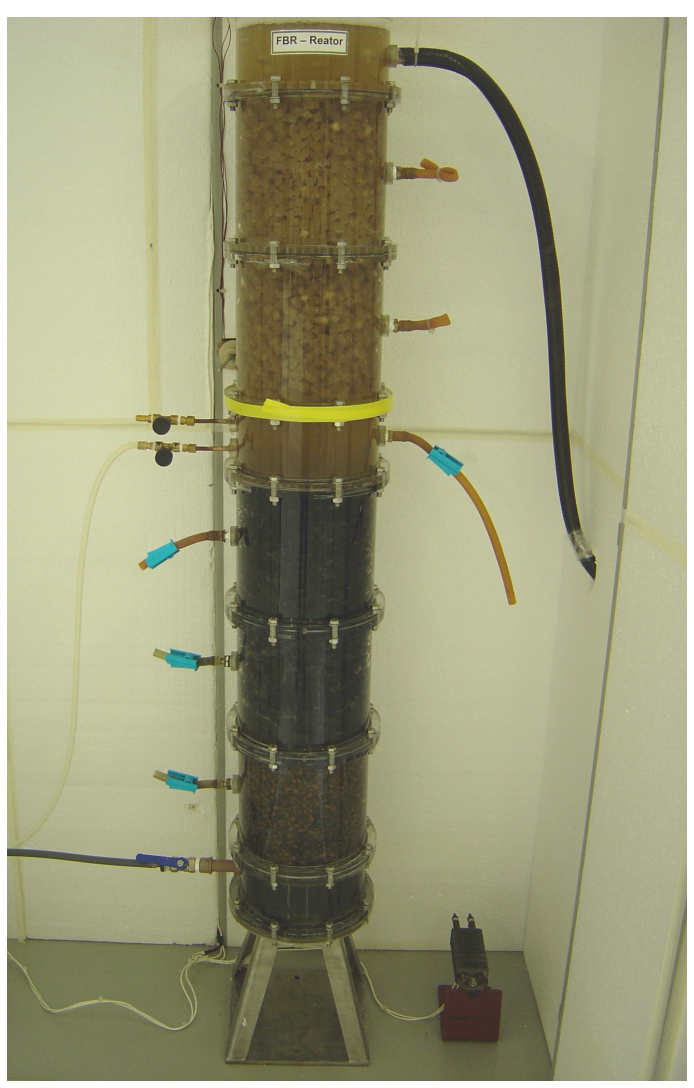

(a)

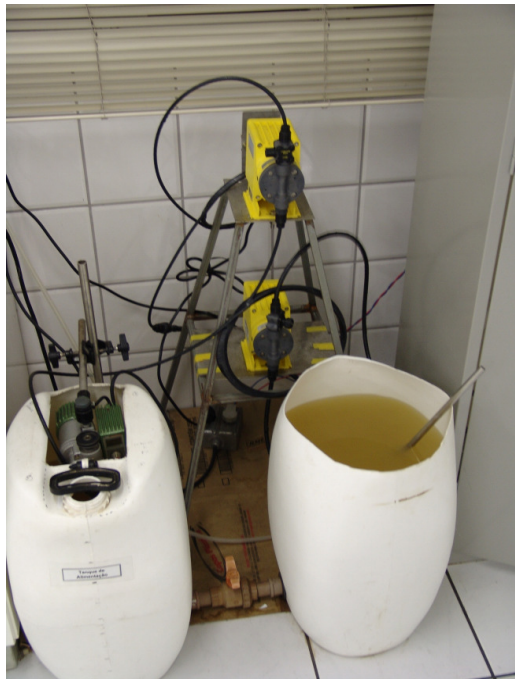

(b)

Figura 4.2 - Fotos da montagem experimental: (a) reator combinado anaeróbio-aeróbio vertical de leito fixo; (b) sistema de alimentação e recirculação interna (bombas diafragma e tanque de armazenamento de água residuária). 


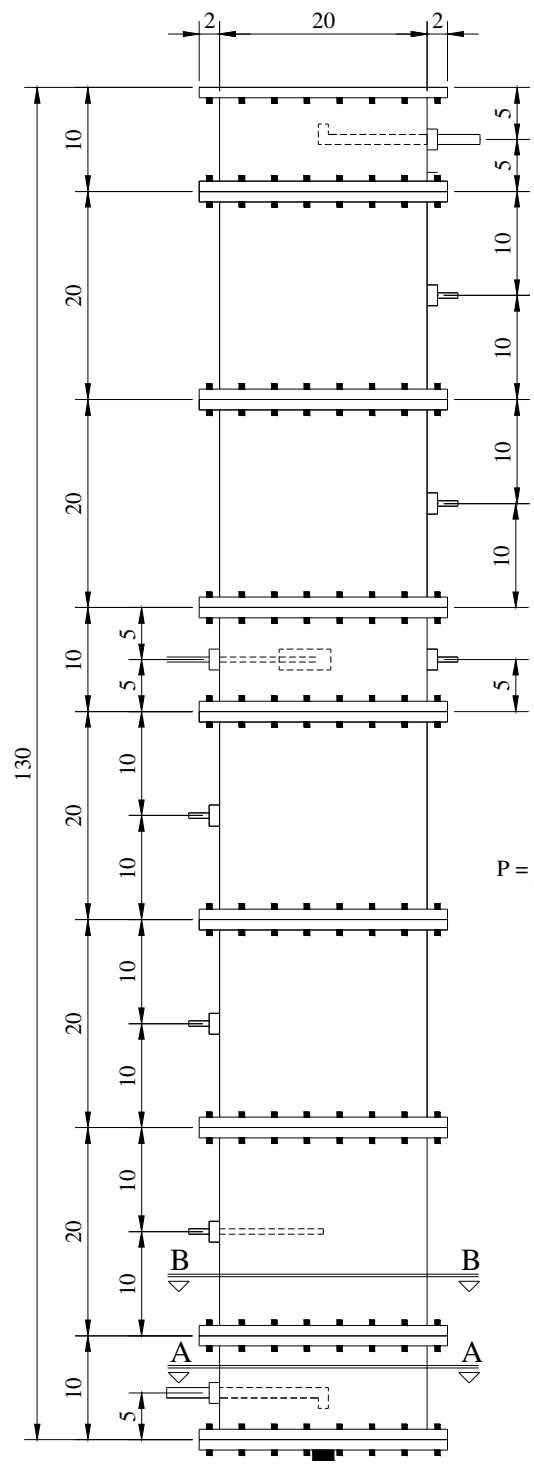

VISTA FRONTAL

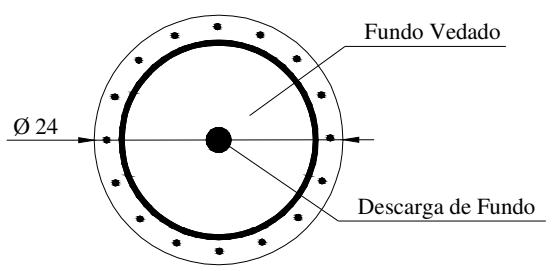

CORTE A-A

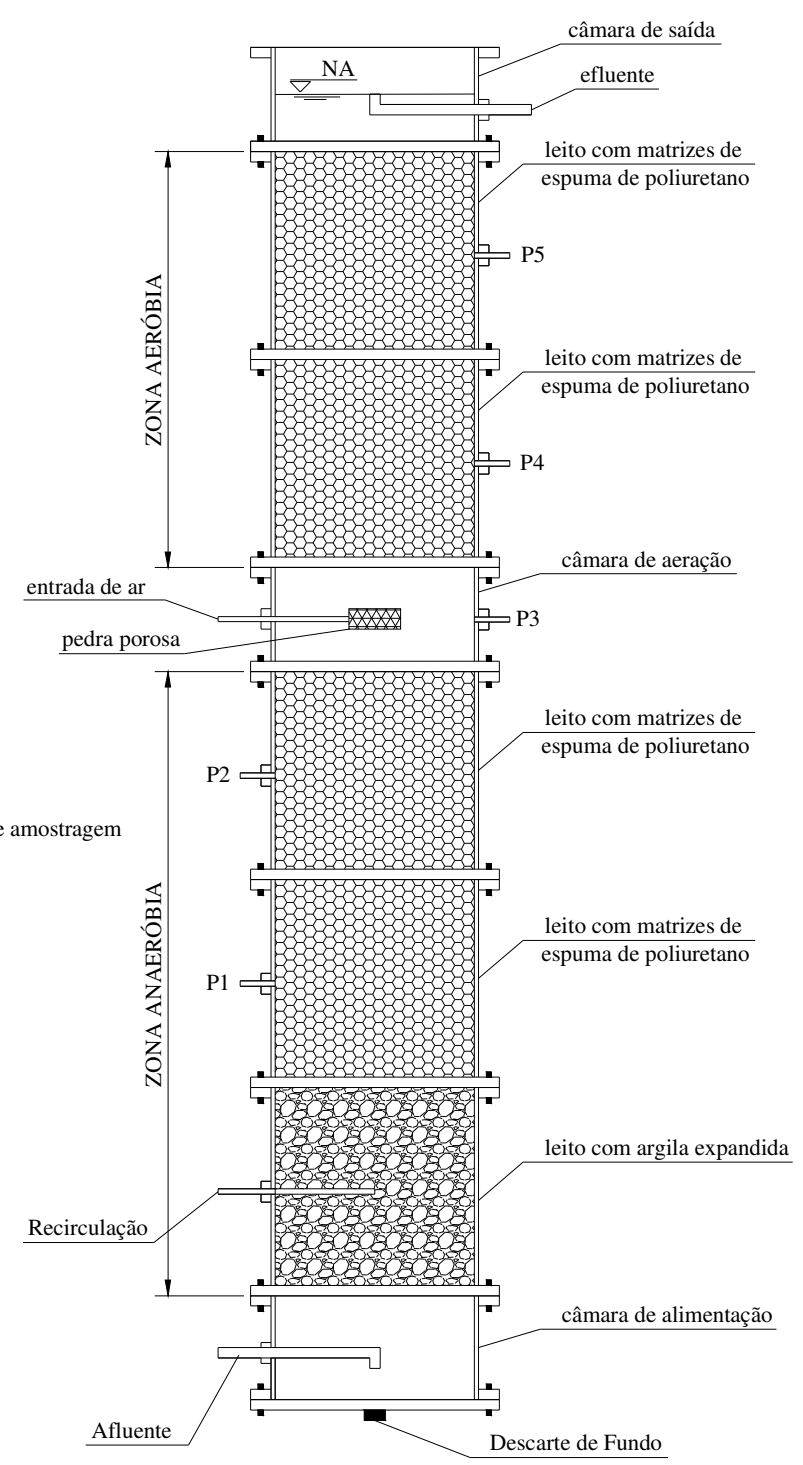

CORTE LONGITUDINAL

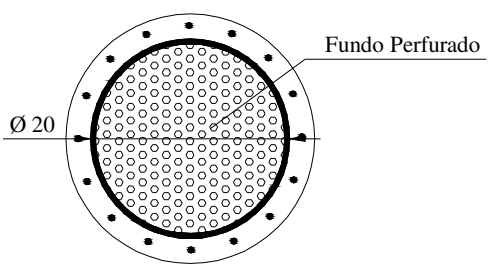

CORTE B-B

Figura 4.3 - Desenho dimensional do reator combinado anaeróbio-aeróbio de leito fixo (medidas em centímetro). 


\subsection{SUPORTES PARA IMOBILIZAÇÃO DA BIOMASSA}

Como suporte de imobilização da biomassa anaeróbia foram utilizados, simultaneamente, dois tipos de suportes, argila expandida e matrizes cúbicas de espuma de poliuretano. Devido à alta concentração afluente de sólidos em suspensão, optou-se por utilizar argila expandida como suporte para o primeiro módulo da zona anaeróbia do reator, minimizando o entupimento do leito reacional causado pela incrustação de sólidos nos posteriores suportes de espuma de poliuretato.

Para a retenção da biomassa aeróbia também foram utilizadas matrizes cúbicas de espuma de poliuretano, idênticas às utilizadas para a imobilização da biomassa anaeróbia.

O leito do reator foi montado utilizando-se $2900 \mathrm{~g}$ de argila expandida no primeiro módulo e $60 \mathrm{~g}$ de matrizes cúbicas de espuma de poliuretano em cada um dos 4 módulos posteriores, 2 anaeróbios e 2 aeróbios, totalizando 240 g de espuma no reator.

Na Tabela 4.1 são apresentadas as características dos suportes utilizados para a imobilização celular no reator.

Tabela 4.1 - Características dos suportes utilizados para imobilização da biomassa.

\begin{tabular}{ccc}
\hline Características & Argila expandida & Espuma de poliuretano \\
\hline Diâmetro equivalente & $8 \mathrm{~mm}$ & $12 \mathrm{~mm}^{\mathrm{a}}$ \\
Massa específica aparente & $510 \mathrm{~g} / \mathrm{l}$ & $10,6 \mathrm{~g} / \mathrm{l}$ \\
Porosidade do leito com suporte & $35 \%^{\mathrm{b}}$ & $45 \%^{\mathrm{b}}$ \\
\hline \multicolumn{2}{c}{${ }^{\mathrm{a}}$ Matrizes cúbicas com 10 mm de aresta } \\
${ }^{\mathrm{b}}$ Valores obtidos empiricamente pela medição dos volumes do leito com suporte e sem suporte
\end{tabular}

\section{4 ÁGUA RESIDUÁRIA}

A água residuária estudada foi escolhida por ser uma das principais correntes de efluentes da fábrica da Ajinomoto, oriunda do processo de purificação do aminoácido Lisina. As características médias deste efluente são apresentadas na Tabela 4.2.

Para a alimentação do sistema utilizou-se um tanque de estoque de 40 litros que possuía um agitador mecânico, mantendo a solução sempre homogeneizada. A cada 24 horas o tanque era limpo e novamente cheio com o efluente da fábrica. 
Tabela 4.2 - Composição média da água residuária industrial estudada.

\begin{tabular}{|c|c|}
\hline Parâmetros & Valores médios \\
\hline $\mathrm{pH}$ & 7,5 \\
\hline DQO bruta & $1300 \mathrm{mg}$ DQO/1 \\
\hline NTK & $150 \mathrm{mg} \mathrm{N} / \mathrm{l}$ \\
\hline $\mathrm{N}-\mathrm{NH}_{4}{ }^{+}$ & 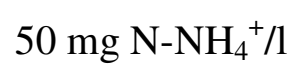 \\
\hline Sólidos totais & $1400 \mathrm{mg} \mathrm{ST} / 1$ \\
\hline Sólidos suspensos totais & 210 mg SST/1 \\
\hline Sólidos suspensos voláteis & $200 \mathrm{mg} \mathrm{SSV/1}$ \\
\hline Alcalinidade a bicarbonato & $65 \mathrm{mg} \mathrm{CaCO} 3 / 1$ \\
\hline Sulfato & $25 \mathrm{mg} \mathrm{SO}_{4}^{-2} / 1$ \\
\hline
\end{tabular}

\subsection{INÓCULO}

Visando a partida rápida do sistema, os suportes de espuma de poliuretano, tanto anaeróbios quanto aeróbios foram inoculados.

Os módulos de espuma da zona anaeróbia foram inoculados com biomassa proveniente de reator UASB tratando água residuária de abatedouro de aves, da empresa Avícola Dacar S.A., localizada em Tietê, SP. O lodo anaeróbio possuía boa granulação com concentração de sólidos em suspensão totais (SST) de aproximadamente $10 \mathrm{~g}$ $\mathrm{SST} / 1$.

Os módulos de espuma da zona aeróbia foram inoculados com biomassa proveniente do próprio sistema de tratamento da Ajinomoto, um reator Bardenpho de quatro estágios. O lodo aeróbio possuía boa condição de sedimentabilidade (IVL $\approx 100$ $\mathrm{ml} / \mathrm{g}$ ) com concentração aproximada de sólidos em suspensão totais de 5 g SST/l.

O módulo de argila expandida não foi inoculado, sendo colonizado naturalmente durante a operação do sistema.

\subsection{ANÁLISES FÍSICO-QUÍMICAS}

Análises de parâmetros como demanda química de oxigênio, nitrogênio amoniacal, nitrogênio total Kjeldahl, nitrito, nitrato e sólidos foram realizados segundo 
o Standard Methods for the Examination of Water and Wastewater (1998). Alcalinidade total e ácidos voláteis totais foram analisadas utilizando método titulométrico proposto por Dilallo \& Albertson (1961) e modificado por Ripley et al. (1986).

Demanda química de oxigênio (DQO): as análises foram realizadas por meio da digestão com refluxo fechado durante duas horas e utilizando-se o método espectrofotométrico com leitura no comprimento de onda de $620 \mathrm{~nm}$. Para DQO filtrada, as amostras foram previamente filtradas a vácuo em membrana de fibra de vidro com poros de $1,2 \mu \mathrm{m}$ de diâmetro.

Nitrogênio amoniacal $\left(\mathbf{N}-\mathbf{N H}_{4}{ }^{+}\right)$: as amostras foram inicialmente destiladas e em seguida analisadas pelo método titulométrico.

Nitrogênio total Kjeldahl (NTK): Foi empregado o método macro-Kjeldahl (digestão em meio ácido) seguido por etapa de destilação e análise titulométrica.

Nitrogênio na forma de nitrito $\left(\mathrm{N}_{-} \mathrm{NO}_{2}^{-}\right)$: utilizou-se o método espectrofotométrico em comprimento de onda de $543 \mathrm{~nm}$. As amostras foram préfiltradas em membranas de celulose com diâmetro de poros igual a $0,45 \mu \mathrm{m}$.

Nitrogênio na forma de nitrato $\left(\mathbf{N}-\mathbf{N O}_{3}{ }^{-}\right)$: utilizou-se o método espectrofotométrico com leituras nos comprimentos de onda de $220 \mathrm{~nm}$ e $275 \mathrm{~nm}$. As amostras foram pré-filtradas em membranas de celulose com diâmetro de poros igual a $0,45 \mu \mathrm{m}$.

Sólidos totais (ST): foram determinados pelo método gravimétrico utilizando-se recipientes de porcelana para secagem das amostras.

Sólidos em suspensão totais (SST) e sólidos em suspensão voláteis (SSV): Foram determinados pelo método gravimétrico, utilizando-se membranas de fibra de vidro com diâmetro de poros igual a 1,2 $\mu \mathrm{m}$.

Alcalinidade: as análises de alcalinidade total e à bicarbonato foram realizadas por método titulométrico e expressas em concentração de carbonato de cálcio.

Ácidos voláteis totais: as análises de ácidos voláteis totais foram realizadas por método titulométrico e expressas em concentração de ácido acético.

Oxigênio dissolvido (OD): empregou-se o método potenciométrico com eletrodo de membrana.

Potencial hidrogeniônico (pH): as medidas de $\mathrm{pH}$ foram realizadas por método potenciométrico. 


\subsubsection{Quantificação da biomassa aderida nos suportes}

Para quantificar a biomassa aderida aos suportes de espuma de poliuretano e argila expandida utilizou-se o seguinte procedimento analítico:

1) Coletou-se uma porção de suporte no qual a biomassa estava aderida e transferiu-a para um frasco de $50 \mathrm{ml}$;

2) Adicionou-se ao frasco $10 \mathrm{ml}$ de água destilada e, para o caso da espuma, adicionou-se também pérolas de vidro;

3) Tampou-se o frasco e agitou-se energicamente durante 20 minutos, promovendo o desprendimento da biomassa do suporte;

4) Após agitação, o líquido foi separado do suporte e das pérolas de vidro e transferido para uma cápsula de porcelana de $50 \mathrm{ml}$, previamente pesada $\left(\mathrm{P}_{0}\right)$. A porção de suporte foi transferida para uma cápsula de vidro. Utilizouse cerca de $5 \mathrm{ml}$ de água destilada para lavagem das pérolas de vidro;

5) A cápsula de porcelana contendo o líquido separado e a cápsula de vidro contendo o suporte foram levadas à estufa, ajustada para temperatura de $105^{\circ} \mathrm{C}$, onde permaneceram até peso constante por cerca de 24 horas;

6) Decorrido o tempo de secagem, a cápsula de porcelana e os suportes foram pesados, obtendo-se as respectivas massas $\mathrm{P}_{1}$ e $\mathrm{P}_{\text {suporte; }}$;

7) Após pesagem, a cápsula de porcelana foi transferida para a mufla, ajustada para temperatura de $500^{\circ} \mathrm{C}$, onde permaneceu por 2 horas;

8) Finalmente, após a calcinação na mufla, a cápsula de porcelana contendo o líquido separado novamente foi pesada, obtendo-se o valor de $\mathrm{P}_{2}$;

Este procedimento foi executado ao final da etapa experimental, quando as amostras de suporte de argila expandida e espuma de poliuretano foram retiradas após a abertura do reator.

Assim, calculou-se a massa de sólidos totais (ST) e sólidos voláteis totais (SVT) aderidos por massa de suporte, conforme apresentados nas Equações 4.1 e 4.2.

$$
\begin{gathered}
S T=\frac{P_{1}-P_{0}}{P_{\text {sup orte }}} \\
S V T=\frac{P_{1}-P_{2}}{P_{\text {sup orte }}}
\end{gathered}
$$




\subsection{EXAMES MICROBIOLÓGICOS}

Ao final da fase de operação, foram realizados exames microbiológicos da biomassa de amostras retiradas ao longo do reator. Os pontos de amostragem e os tipos de exames realizados são apresentados na Figura 4.4 e Tabela 4.3, respectivamente.

Tabela 4.3 - Tipo de exame microbiológico realizado para cada ponto de amostragem.

\section{Tipo de exame microbiológico}

\section{Pontos de amostragem}

(Indicados na Figura 4.4)

Caracterização morfológica (microscopia ótica)

NMP de bactérias nitrificantes

NMP de bactérias heterótrofas

NMP de bactérias desnitrificantes
$1,2,3,4,5$ e 6

\section{5}

5

$1,2,3$ e 5

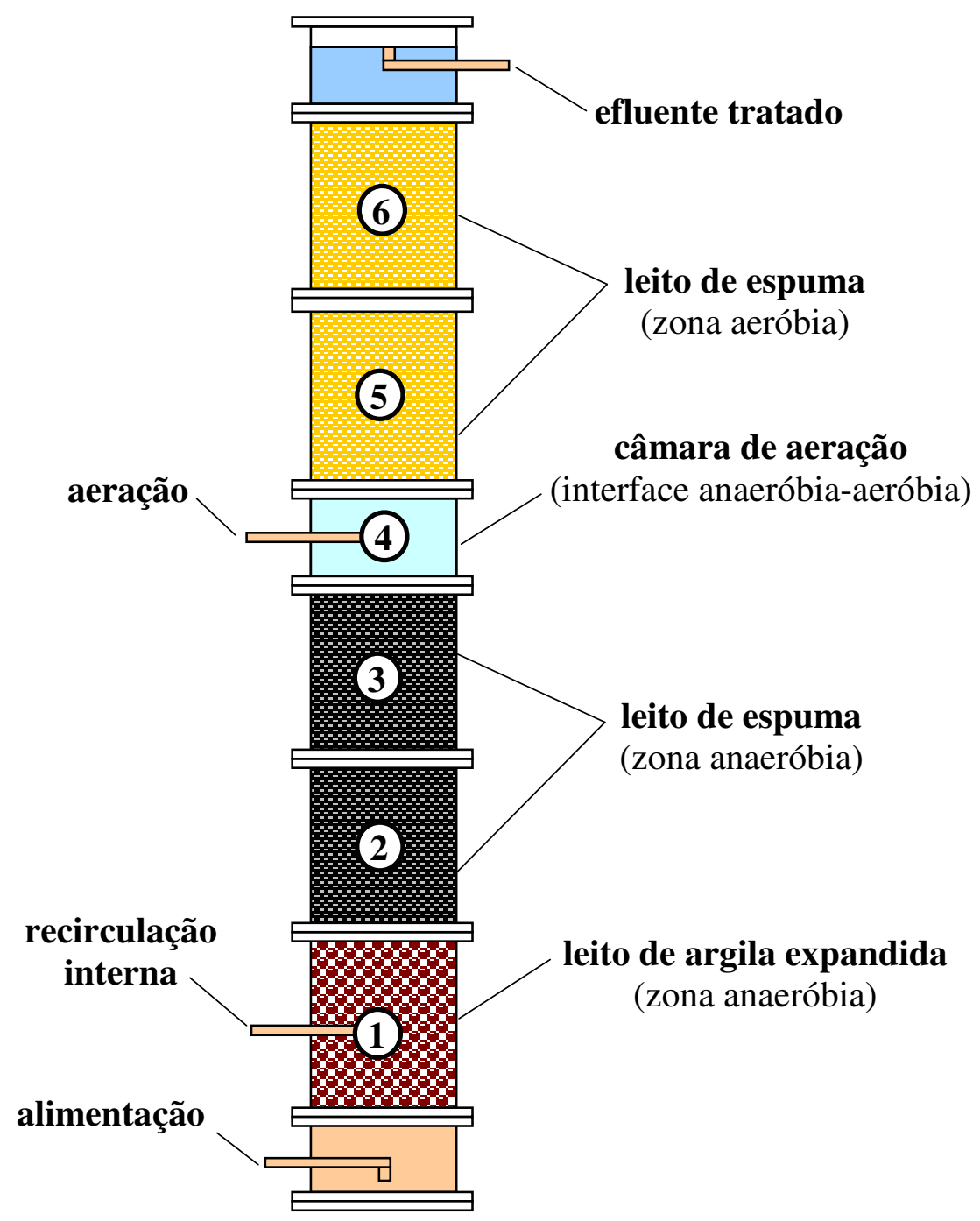

Figura 4.4 - Pontos de amostragem de biomassa para exames microbiológicos. 


\subsubsection{Caracterização morfológica do biofilme}

A caracterização morfológica do biofilme anaeróbio e aeróbio foi realizada por microscopia ótica de contraste de fase e de fluorescência utilizando microscópio LEICA DMLB. As imagens foram capturadas por sistema de câmera digital Optronics e software Image Pro-Plus 4.5.0.

As amostras de biomassa foram extraídas por maceramento e compressão do meio suporte, no caso das matrizes de espuma de poliuretano, e por raspagem superficial, no caso da argila expandida. Todas as amostras foram examinadas em lâmina de vidro cobertas com filme de Agar $2 \%$.

\subsubsection{Número mais provável (NMP) de bactérias nitrificantes}

A estimativa do Número Mais Provável (NMP) de bactérias nitrificantes foi realizada segundo método descrito por Schmidt e Belser (1984), adaptado para amostras de águas residuárias, pois o método foi desenvolvido originalmente para amostras de solo (MENDONÇA,2002).

\section{Preparo das amostras:}

As amostras de biomassa foram extraídas por compressão das matrizes de espuma de poliuretano. As amostras foram transferidas para frasco contendo cerca de 5 g de pérolas de vidro, sendo agitado manualmente por 20 minutos. Esse preparo foi realizado para permitir a quebra dos flocos do lodo biológico.

\section{Preparo da água de diluição:}

1) Em um béquer de $500 \mathrm{~mL}$, adicionou-se $2 \mathrm{ml}$ de solução de $\mathrm{K}_{2} \mathrm{HPO}_{4}(3,48$ $\mathrm{g} / 100 \mathrm{ml}), 0,5 \mathrm{ml}$ de solução de $\mathrm{KH}_{2} \mathrm{PO}_{4}(2,72 \mathrm{~g} / 100 \mathrm{ml})$ e completou-se o volume para $500 \mathrm{~mL}$ com água Milli-Q;

2) Adicionou-se $18 \mathrm{~mL}$ de água de diluição em cada tubo de ensaio. Posteriormente, os tubos de ensaio foram tampados com rolhas de algodão envoltos em gaze e esterilizados em autoclave por 20 minutos, sob pressão de $1 \mathrm{~atm}$ e temperatura de $120^{\circ} \mathrm{C}$.

3) Sob ambiente de assepsia (próximo ao bico de Bunsen) foram realizadas as 
diluições necessárias, seguindo o seguinte procedimento:

- Adicionou-se $2 \mathrm{ml}$ de amostra de lodo biológico previamente preparado em um tubo de ensaio contendo água de diluição $(18 \mathrm{ml})$, obtendo-se a diluição $10^{-1}$;

- Após homogeneização, retirou-se $2 \mathrm{ml}$ do tubo com diluição de $10^{-1} \mathrm{e}$ adicionou-se a outro tubo contendo água de diluição, obtendo-se assim a diluição de $10^{-2}$;

- Esse procedimento foi seguido até que todas as diluições desejadas fossem obtidas para cada meio de cultura utilizado.

A determinação do NMP de bactérias nitrificantes foi realizada separadamente para bactérias oxidadoras de amônia e para bactérias oxidadoras de nitrito, conforme descrição apresentada a seguir.

\section{Preparo dos meios de cultura:}

Os meios de cultura para as bactérias oxidadoras de amônia e nitrito foram preparados em béquer com as soluções listadas na Tabela 4.4, completando o volume para $250 \mathrm{ml}$ com água Milli-Q. Após o preparo, o $\mathrm{pH}$ das soluções foi corrigido para valor em torno de 7,5 por meio da adição de gotas de solução de $\mathrm{Na}_{2} \mathrm{CO}_{3}$.

\section{Procedimento analítico:}

1) Adicionou-se $9 \mathrm{ml}$ do meio de cultura em cada tubo de ensaio, sendo utilizados 5 tubos para cada diluição. Especificamente para os oxidadoras de amônia adicionou-se aproximadamente $1 \mathrm{~g}$ de $\mathrm{CaCO}_{3} \mathrm{em}$ cada tubo de ensaio, responsável pelo tamponamento da solução. Posteriormente, os tubos foram tampados com chumaços de algodão envoltos em gaze e levados para esterilização em autoclave, por 20 minutos a temperatura de $120^{\circ} \mathrm{C}$ e pressão de 1 atm;

2) Após esterilização, adicionou-se $1 \mathrm{ml}$ de amostra previamente diluída, sob condição de assepsia, em cada tubo de ensaio contendo o meio de cultura. Esse procedimento foi realizado para cada diluição utilizada, sendo de $10^{-4} \mathrm{a}$ $10^{-7}$ para bactérias oxidadoras de amônia e de $10^{-3}$ a $10^{-6}$ para as oxidadoras de nitrito.

3) Os tubos de ensaio foram incubados durante 30 dias à temperatura de $30^{\circ} \mathrm{C}$. 
Tabela 4.4 - Composição química dos meios de cultura para bactérias oxidadoras de amônia e oxidadoras de nitrito.

\begin{tabular}{|c|c|c|c|}
\hline \multirow{2}{*}{$\begin{array}{l}\text { Constituintes } \\
\text { químicos presentes } \\
\text { no meio de cultura }\end{array}$} & \multirow{2}{*}{$\begin{array}{l}\text { Concentração } \\
\text { da solução } \\
\text { estoque } \\
\left(\text { g.100 } \text { ml}^{-1}\right)\end{array}$} & \multicolumn{2}{|c|}{$\begin{array}{l}\text { Volume da solução estoque } \\
\text { para } 250 \mathrm{ml} \text { de meio }(\mathrm{ml})\end{array}$} \\
\hline & & $\begin{array}{l}\text { Oxidadoras } \\
\text { de amônia }\end{array}$ & $\begin{array}{c}\text { Oxidadoras } \\
\text { de nitrito }\end{array}$ \\
\hline $\mathrm{NaNO}_{2}$ & 0,68 & - & 0,25 \\
\hline$\left(\mathrm{NH}_{4}\right)_{2} \mathrm{SO}_{4}$ & 10 & 1,0 & - \\
\hline $\mathrm{CaCl}_{2} \cdot 2 \mathrm{H}_{2} \mathrm{O}$ & 1,34 & 0,25 & 0,25 \\
\hline $\mathrm{MgSO}_{4} .7 \mathrm{H}_{2} \mathrm{O}$ & 4,0 & 0,25 & 1,25 \\
\hline Azul de bromotimol & 0,04 & 0,7 & - \\
\hline $\mathrm{KH}_{2} \mathrm{PO}_{4}$ & 2,72 & 1,88 & 0,25 \\
\hline $\mathrm{K}_{2} \mathrm{HPO}_{4}$ & 3,48 & - & 1,0 \\
\hline Ferro quelante & & 0,25 & 0,25 \\
\hline $\mathrm{FeSO}_{4} \cdot 7 \mathrm{H}_{2} \mathrm{O}$ & 0,246 & & \\
\hline EDTA dissódio & 0,331 & & \\
\hline Elementos traço & & 0,25 & 0,25 \\
\hline $\mathrm{NaMoO}_{4} \cdot 2 \mathrm{H}_{2} \mathrm{O}$ & 0,01 & & \\
\hline $\mathrm{MnCl}_{2}$ & 0,02 & & \\
\hline $\mathrm{CoCl}_{2} \cdot 6 \mathrm{H}_{2} \mathrm{O}$ & 0,0002 & & \\
\hline $\mathrm{ZnSO}_{4} \cdot 7 \mathrm{H}_{2} \mathrm{O}$ & 0,01 & & \\
\hline $\mathrm{CuSO}_{4} .5 \mathrm{H}_{2} \mathrm{O}$ & 0,002 & & \\
\hline
\end{tabular}

\section{Resultado:}

Finalizado o período de incubação, realizou-se medição da presença de nitrito em cada tubo de ensaio através da adição de 3 gotas de solução de sulfanilamida $(0,5 \mathrm{~g}$ dissolvido em $100 \mathrm{ml}$ de ácido clorídrico 2,4 N) e em seguida, 3 gotas da solução de naftil-etilenodiamina hidrocloreto $(0,3 \mathrm{~g}$ dissolvido em $100 \mathrm{ml}$ de ácido clorídrico, 0,12 N). A presença de nitrito era confirmada pela coloração rosa avermelhada. Para os tubos de ensaio com meio de cultura específico para as bactérias oxidadoras de amônia, a presença de nitrito representava resultado positivo, ou seja, houve a oxidação do nitrogênio amoniacal a nitrito. No caso dos tubos de ensaio com meio de cultura específico para bactérias oxidadoras de nitrito, a presença de nitrito indicava resultado negativo, ou seja, ausência de oxidação do nitrito. A contagem de NMP de bactérias 
nitrificantes oxidadoras de amônia e oxidadoras de nitrito foi feita com a combinação das respectivas respostas positivas utilizando a tabela padrão de probabilidade (ALEXANDER, 1984).

\subsubsection{Número mais provável (NMP) de bactérias heterótrofas e desnitrificantes}

A estimativa do Número Mais Provável (NMP) de bactérias denitrificantes e heterótrofas foi realizada segundo método descrito por Tiedje (1984), adaptado para amostras de águas residuárias, pois o método foi desenvolvido originalmente para amostras de solo (MENDONÇA,2002).

Para o exame das bactérias heterótrofas e desnitrificantes foram utilizados os mesmos procedimentos de preparo das amostras de biomassa e água de diluição utilizados para o exame das bactérias nitrificantes, descrito no item 4.7.2.

\section{Preparo dos meios de cultura:}

Os meios de cultura para as bactérias heterótrofas e desnitrificantes foram preparados com $4 \mathrm{~g}$ de meio nutriente genérico (nutrient broth) dissolvido em $500 \mathrm{ml}$ de água Milli-Q. Após a dissolução, separou-se $250 \mathrm{ml}$ da solução para ser utilizado exclusivamente para a incubação das bactérias desnitrificantes e adicionou-se $0,107 \mathrm{~g}$ de $\mathrm{NaNO}_{3}$. O restante foi utilizado para a incubação das bactérias heterótrofas.

\section{Procedimento analítico:}

1) Adicionou-se $4,5 \mathrm{ml}$ do meio de cultura em cada tubo de ensaio, sendo utilizados 5 tubos para cada diluição. Os tubos contendo meio de cultura para as bactérias heterotróficas foram tampados com chumaços de algodão envoltos em gaze e os tubos contendo meio de cultura para as bactérias desnitrificantes foram vedados com tampa para impedir a entrada de oxigênio. Todos os tubos foram esterilizados em autoclave por 20 minutos a temperatura de $120^{\circ} \mathrm{C}$ e pressão de 1 atm;

2) Após esterilização, adicionou-se $0,5 \mathrm{ml}$ de amostra previamente diluída, sob condição de assepsia, em cada tubo de ensaio contendo o meio de cultura. Esse procedimento foi realizado para cada diluição utilizada, sendo de $10^{-6} \mathrm{a}$ $10^{-9}$ para bactérias heterótrofas e de $10^{-5}$ a $10^{-8}$ para as desnitrificantes. 
3) Os tubos de ensaio foram incubados durante 30 dias à temperatura de $30^{\circ} \mathrm{C}$.

\section{Resultado:}

Finalizado o período de incubação, realizou-se medição da presença de nitrato nos tubos com meio de cultura específico para as bactérias desnitrificantes através da adição de 3 gotas de solução de difenilamina (0,2 g dissolvido em $100 \mathrm{ml}$ de ácido sulfúrico concentrado). A ausência de coloração indicava o consumo do nitrato e a possível presença de bactérias desnitrificantes (resultado positivo) e a coloração azul significava que ainda havia nitrato remanescente, portanto, ausência de desnitrificação (resultado negativo).

Para as bactérias heterótrofas, os tubos que apresentaram turvação do meio de cultura, indicando a atividade heterótrofa, foram considerados positivos. Os tubos que mantiveram a coloração inicial do meio de cultura (translúcido) foram considerados negativos.

A contagem de NMP de bactérias heterótrofas e desnitrificantes foi feita com a combinação das respectivas respostas positivas, utilizando a tabela padrão de probabilidade (ALEXANDER, 1984).

\subsection{PROCEDIMENTO EXPERIMENTAL}

A investigação experimental foi realizada em quatro etapas principais. $\mathrm{Na}$ primeira estudou-se o comportamento do reator vertical de leito fixo operando unicamente em condição anaeróbia. Posteriormente, na segunda etapa, acoplaram-se módulos aeróbios ao reator, avaliando-se o comportamento do mesmo operando em condição combinada anaeróbia-aeróbia. Na terceira etapa, os módulos anaeróbios e aeróbios foram separados em dois reatores distintos e verificou-se o desempenho do sistema operando com os reatores anaeróbio e aeróbio em série. Por fim, na quarta etapa, os módulos aeróbios foram reacoplados aos módulos anaeróbios, conforme configuração da segunda etapa, avaliando-se o desempenho do reator combinado anaeróbio-aeróbio operando com recirculação de efluente tratado. Em todas as etapas, os reatores foram operados continuamente, à temperatura de $30 \pm 1{ }^{\circ} \mathrm{C}$. 


\subsubsection{Etapa 1 - Reator anaeróbio vertical de leito fixo}

Nesta etapa analisou-se o comportamento do reator vertical de leito fixo operando unicamente em condição anaeróbia, verificando a sua eficiência na remoção de matéria orgânica e na amonificação do nitrogênio orgânico proveniente do substrato. O reator foi montado apenas com os primeiros módulos, como mostrado na Figura 4.5.

O volume total do reator anaeróbio era de 21,8 1, sendo 2,8 1 da câmara de alimentação, 5,7 1 do leito de argila expandida, 11,3 1 do leito de espuma de poliuretano e 2,0 1 da câmara de saída. Como as porosidades dos leitos de argila expandida e espuma de poliuretano eram de $35 \%$ e $45 \%$, respectivamente, o reator anaeróbio possuía volume líquido total de 11,9 1. Para o cálculo do volume útil do reator, considerou-se que as partes que não possuíam biomassa imobilizada, no caso as câmaras de alimentação e saída, tinham pequena contribuição no processo de tratamento da água residuária e então não foram contabilizadas. Assim, o volume útil do reator anaeróbio de leito fixo foi considerado igual a 17 litros (5,7 1 do leito de argila expandida e 11,3 1 do leito de espuma de poliuretano).

Como procedimento de inoculação do reator, os grânulos do lodo de inóculo foram macerados e colocados em contato com as matrizes de espuma de poliuretano em um balde de 201 por cerca de 24 horas. Após esse período, as matrizes foram transferidas para os módulos do reator, preenchendo todo o volume dos mesmos. Finalizada a transferência, os módulos foram montados e completou-se o volume do reator com água potável, ficando pronto para iniciar a primeira etapa de operação.

Com o objetivo de adaptar a biomassa inoculada ao efluente da Ajinomoto, o reator anaeróbio de leito fixo foi posto em marcha por meio de uma rampa de alimentação. Fixando-se a vazão afluente em 1,5 1/h, aumentou-se a concentração da solução de alimentação gradativamente, iniciando-se em $25 \%$ até $100 \%$ de água residuária. O período de adaptação teve duração de 30 dias, finalizando-se a partir do início da alimentação com $100 \%$ de água residuária.

Buscando investigar a melhor condição operacional, após o período de adaptação da biomassa, o reator anaeróbio foi operado com tempos de detenção hidráulica iguais a $11 \mathrm{~h}, 17 \mathrm{~h}, 21 \mathrm{~h}$ e $24 \mathrm{~h}$, baseado no volume útil do reator (17 1), com vazões afluentes de 1,5 1/h, 1,0 1/h, 0,8 1/h e 0,7 1/h, respectivamente. Para a avaliação de desempenho do sistema foram coletadas amostras diárias do afluente e do efluente do reator e analisadas conforme apresentado no item 4.6.1. 
As variáveis analisadas durante a operação do reator anaeróbio, os métodos utilizados e as frequiências das análises são apresentadas na Tabela 4.5.

Tabela 4.5 - Variáveis analisadas, métodos utilizados e freqüência de amostragem durante a operação do reator anaeróbio vertical de leito fixo.

\begin{tabular}{|c|c|c|c|}
\hline Variáveis analisadas & $\begin{array}{c}\text { Pontos de } \\
\text { amostragem }^{\mathrm{a}}\end{array}$ & Método analítico & $\begin{array}{c}\text { Freqüiência } \\
\text { semanal }\end{array}$ \\
\hline Temperatura $\left({ }^{\circ} \mathrm{C}\right)$ & $A$ e E & Termométrico & 6 a 7 vezes \\
\hline Oxigênio dissolvido $\left(\mathrm{mg} \mathrm{O}_{2} / \mathrm{l}\right)$ & A e E & Potenciométrico & 6 a 7 vezes \\
\hline $\mathrm{pH}$ & $\mathrm{A}$ e $\mathrm{E}$ & Potenciométrico & 6 a 7 vezes \\
\hline Alcalinidade $\left(\mathrm{mg} \mathrm{CaCO}_{3} / \mathrm{l}\right)$ & $\mathrm{A}$ e $\mathrm{E}$ & Titulométrico & 6 a 7 vezes \\
\hline Ácidos voláteis (mg HAc/l) & A e E & Titulométrico & 6 a 7 vezes \\
\hline DQO bruta $\left(\mathrm{mg} \mathrm{O}_{2} / \mathrm{l}\right)$ & A e E & Espectrofotométrico & 6 a 7 vezes \\
\hline DQO filtrada $\left(\mathrm{mg} \mathrm{O}_{2} / \mathrm{l}\right)$ & A e E & Espectrofotométrico & 6 a 7 vezes \\
\hline N-NTK (mg N/l) & $\mathrm{A}$ e $\mathrm{E}$ & Titulométrico & 6 a 7 vezes \\
\hline $\mathrm{N}-\mathrm{NH}_{4}{ }^{+}(\mathrm{mg} \mathrm{N} / \mathrm{l})$ & A e E & Titulométrico & 6 a 7 vezes \\
\hline $\mathrm{ST}(\mathrm{mg} \mathrm{ST} / \mathrm{l})$ & A e E & Gravimétrico & 6 a 7 vezes \\
\hline $\mathrm{SST}(\mathrm{mg} \mathrm{SST} / 1)$ & A e E & Gravimétrico & 6 a 7 vezes \\
\hline $\mathrm{SSV}(\mathrm{mg} \mathrm{SSV} / \mathrm{l})$ & $\mathrm{A}$ e $\mathrm{E}$ & Gravimétrico & 6 a 7 vezes \\
\hline
\end{tabular}

\footnotetext{
${ }^{\mathrm{a}} \mathrm{A}=$ Alimentação (afluente);
}

$\mathrm{E}=$ Efluente tratado. 


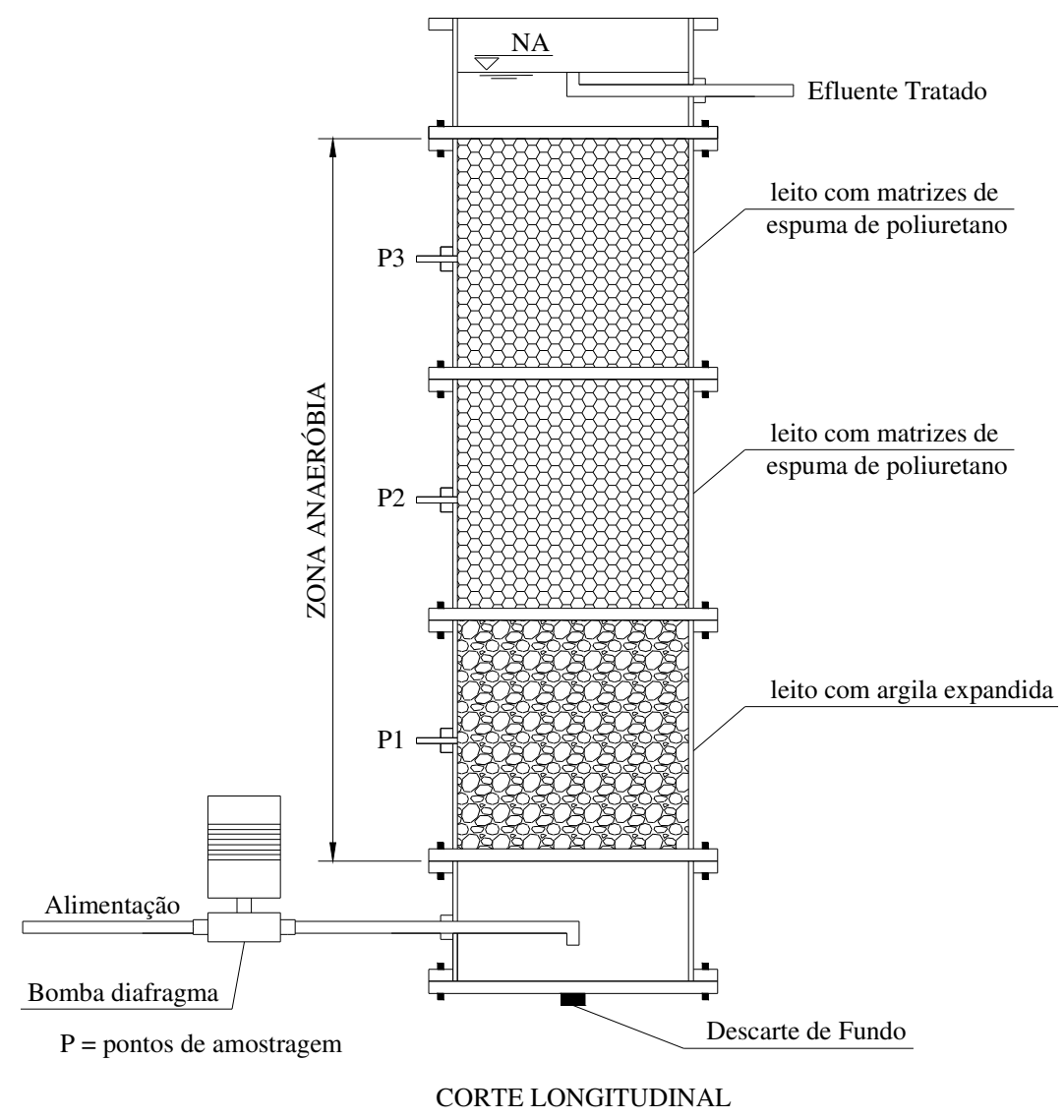

Figura 4.5 - Desenho esquemático do reator anaeróbio vertical de leito fixo.

\subsubsection{Etapa 2 - Reator combinado anaeróbio-aeróbio vertical de leito fixo}

Nesta etapa analisou-se o comportamento do reator vertical de leito fixo operando em condição combinada anaeróbia-aeróbia. No topo do reator anaeróbio foi introduzida uma câmara de aeração e posteriormente mais dois módulos com suporte de espuma de poliuretano, permitindo a combinação dos sistemas anaeróbio e aeróbio em uma única unidade, conforme mostrado na Figura 4.6.

O volume total do reator combinado anaeróbio-aeróbio era de 35,9 1, sendo 2,8 1 da câmara de alimentação, 5,7 1 do leito de argila expandida, 11,3 1 do leito de espuma anaeróbio, 2,8 1 da câmara de aeração, 11,3 1 do leito de espuma aeróbio e 2,0 1 da câmara de saída. Como as porosidades dos leitos de argila expandida e espuma de poliuretano eram de $35 \%$ e $45 \%$, respectivamente, o volume líquido total do reator combinado anaeróbio-aeróbio era de 19,8 1, sendo 9,9 1 da zona anaeróbia e 9,9 1 da zona aeróbia. Para o cálculo do volume útil do reator, analogamente a etapa anterior, considerou-se que as partes que não possuíam biomassa imobilizada, no caso as 
câmaras de alimentação, aeração e saída, tinham pequena contribuição no processo de tratamento da água residuária e então não foram contabilizadas. Assim, os volumes úteis dos reatores anaeróbio e aeróbio foram considerados iguais a 17 litros (5,7 1 do leito de argila expandida mais 11,3 1 do leito de espuma anaeróbio) e 11,3 litros (leito de espuma aeróbio), respectivamente, totalizando 28,3 litros de volume útil total do reator combinado anaeróbio-aeróbio.

Para a inoculação dos módulos aeróbios, as matrizes de espuma de poliuretano foram colocadas em contato com o lodo de inóculo em um balde de 201 por aproximadamente 2 horas, mantendo-se a solução com aeração constante. Decorrido o tempo de contato, as matrizes foram transferidas para os módulos do reator, preenchendo todo o volume dos mesmos. Por fim, os módulos foram montados e completou-se o volume do reator com efluente tratado do reator anaeróbio, ficando pronto para iniciar a segunda etapa de operação.

Partindo da melhor condição operacional alcançada para o reator anaeróbio na etapa 1, fixou-se a vazão de alimentação em 0,8 1/h e verificou-se a eficiência do sistema na remoção de matéria orgânica e nitrogênio. Para esta condição, o tempo de detenção hidráulica na zona anaeróbia ficou em 21 h e para a zona aeróbia em 14 h, baseado no volume útil do reator, totalizando $35 \mathrm{~h}$ de TDH no sistema. A aeração na zona aeróbia foi mantida constante e com níveis de oxigênio dissolvido altos, acima de 3,0 mg/l. Devido a ausência de equipamento adequado para a medição, a vazão de ar aplicada no reator não foi quantificada.

Para a avaliação de desempenho do sistema foram coletadas amostras na alimentação e no efluente tratado. As variáveis analisadas durante a operação do reator combinado anaeróbio-aeróbio, os pontos de amostragem, os métodos analíticos utilizados e as freqüências das análises são apresentadas na Tabela 4.6. 
Tabela 4.6 - Variáveis analisadas, pontos de amostragem, métodos analíticos utilizados e freqüência de amostragem durante a operação do reator combinado anaeróbio-aeróbio vertical de leito fixo.

\begin{tabular}{|c|c|c|c|}
\hline Variáveis analisadas & $\begin{array}{c}\text { Pontos de } \\
\text { amostragem }^{\mathrm{a}}\end{array}$ & Método analítico & $\begin{array}{c}\text { Freqüência } \\
\text { semanal }\end{array}$ \\
\hline Temperatura $\left({ }^{\circ} \mathrm{C}\right)$ & $\mathrm{A}$ e E & Termométrico & 5 vezes \\
\hline Oxigênio dissolvido $\left(\mathrm{mg} \mathrm{O}_{2} / \mathrm{l}\right)$ & A e E & Potenciométrico & 5 vezes \\
\hline $\mathrm{pH}$ & $A$ e $E$ & Potenciométrico & 5 vezes \\
\hline Alcalinidade $\left(\mathrm{mg} \mathrm{CaCO}_{3} / \mathrm{l}\right)$ & A e E & Titulométrico & 5 vezes \\
\hline Ácidos voláteis (mg HAc/l) & A e E & Titulométrico & 5 vezes \\
\hline DQO bruta $\left(\mathrm{mg} \mathrm{O}_{2} / \mathrm{l}\right)$ & $A$ e $E$ & Espectrofotométrico & 5 vezes \\
\hline DQO filtrada $\left(\mathrm{mg} \mathrm{O}_{2} / \mathrm{l}\right)$ & A e E & Espectrofotométrico & 5 vezes \\
\hline N-NTK (mg N/l) & A e E & Titulométrico & 5 vezes \\
\hline $\mathrm{N}-\mathrm{NH}_{4}{ }^{+}(\mathrm{mg} \mathrm{N} / \mathrm{l})$ & A e E & Titulométrico & 5 vezes \\
\hline $\mathrm{N}-\mathrm{NO}_{2}^{-}(\mathrm{mg} \mathrm{N} / \mathrm{l})$ & $\mathrm{E}$ & Espectrofotométrico & 5 vezes \\
\hline $\mathrm{N}-\mathrm{NO}_{3}^{-}(\mathrm{mg} \mathrm{N} / 1)$ & $\mathrm{E}$ & Espectrofotométrico & 5 vezes \\
\hline $\mathrm{ST}(\mathrm{mg} \mathrm{ST} / \mathrm{l})$ & A e E & Gravimétrico & 5 vezes \\
\hline SST (mg SST/1) & A e E & Gravimétrico & 5 vezes \\
\hline $\mathrm{SSV}(\mathrm{mg} \mathrm{SSV/l})$ & A e E & Gravimétrico & 5 vezes \\
\hline
\end{tabular}

${ }^{\mathrm{a}} \mathrm{A}=$ Alimentação (afluente); I = Interface entre as zonas anaeróbia e aeróbia (câmara de aeração); $\mathrm{E}=$ Efluente tratado. 


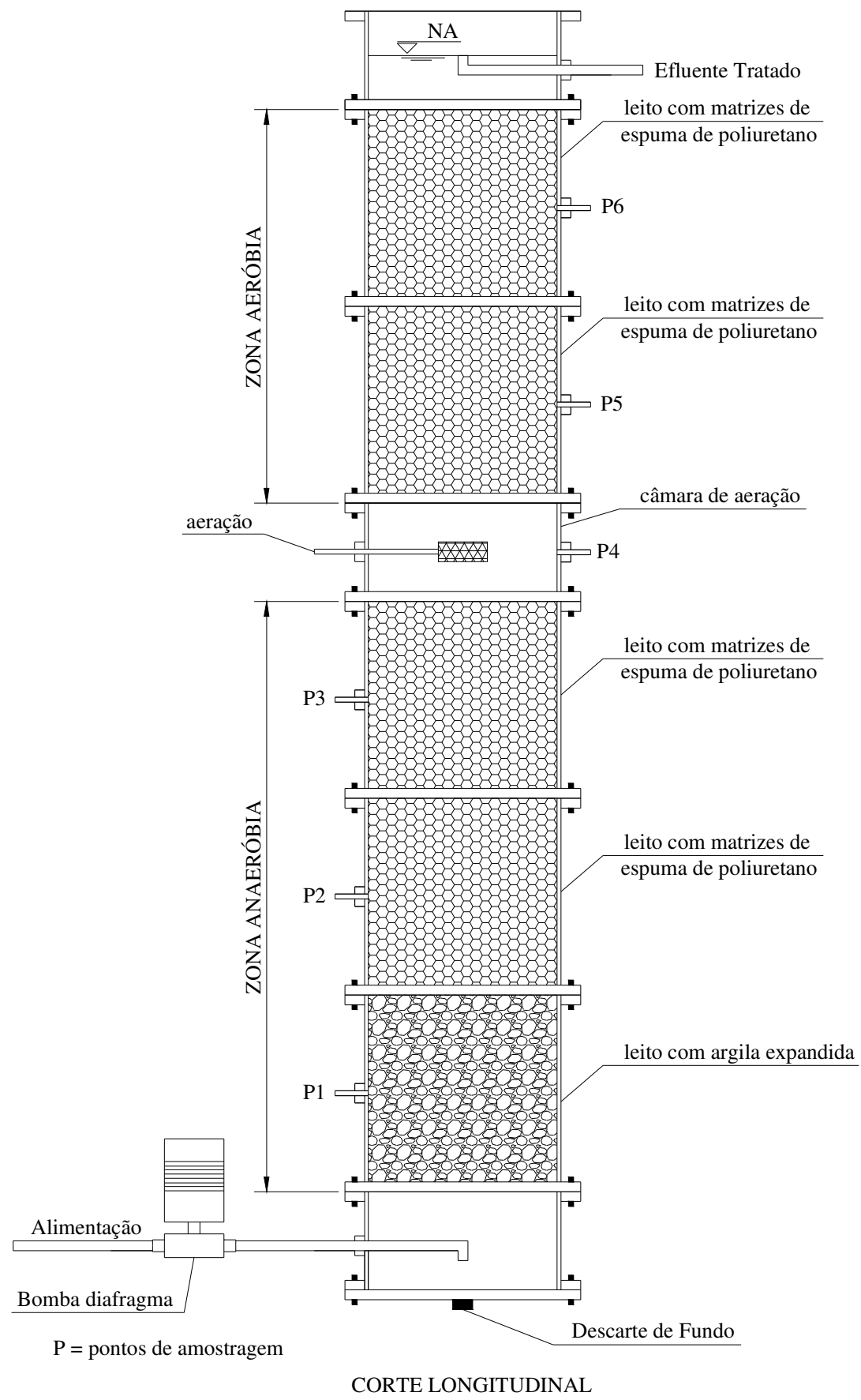

Figura 4.6 - Desenho esquemático do reator combinado anaeróbio-aeróbio vertical de leito fixo. 


\subsubsection{Etapa 3 - Reator anaeróbio vertical de leito fixo em série com reator aeróbio vertical de leito}

$\mathrm{Na}$ terceira etapa experimental, os módulos anaeróbios e aeróbios do reator combinado (etapa 2) foram separados em dois reatores distintos e conectados em série. O reator anaeróbio era alimentado por meio de uma bomba peristáltica e seu efluente encaminhado para o reator aeróbio via diferencial hidráulico, conforme desenho da Figura 4.7.

No topo do reator anaeróbio foi acoplado um módulo de aeração, igual ao utilizado no reator aeróbio, objetivando garantir a mesma condição ambiental apresentada na etapa experimental anterior. Assim, a principal diferença entre as configurações com os reatores conjugados e separados era de que na primeira situação os gases gerados na zona anaeróbia passavam pela zona aeróbia do reator antes de serem liberados na atmosfera e na segunda situação os gases eram liberados no próprio reator anaeróbio, sem passar pelo reator aeróbio.

O volume total do reator anaeróbio para esta etapa era de 24,6 litros, sendo 2,8 1 da câmara de alimentação, 5,7 1 do leito de argila expandida, 11,3 1 do leito de espuma de poliuretano, 2,8 1 da câmara de aeração e 2,0 1 da câmara de saída. Os volumes líquido e útil do reator anaeróbio, considerando porosidade no leito de argila expandida de $35 \%$ e no leito de espuma de poliuretano de 45\%, eram de 14,7 1 e 171 , respectivamente. O reator aeróbio possuía volume total de 18,9 litros, sendo 2,8 1 da câmara de alimentação, 2,8 1 da câmara de aeração, 11,3 1 do leito de espuma aeróbio e 2,0 1 da câmara de saída, com volumes líquido e útil iguais a 12,7 1 e 11,3 1, respectivamente.

Mantendo a mesma condição operacional da etapa anterior, fixou-se a vazão de alimentação em 0,8 1/h e verificou-se a eficiência do sistema na remoção de matéria orgânica e nitrogênio. Como a vazão de alimentação e o volume útil dos reatores não foram alterados após a separação dos módulos, os tempos de detenção hidráulica mantiveram-se os mesmos, sendo de $21 \mathrm{~h}$ para o reator anaeróbio e de 14 h para o reator aeróbio, baseado no volume útil dos reatores, totalizando $35 \mathrm{~h}$ de TDH no sistema. A aeração no reator aeróbio e no topo do reator anaeróbio foi mantida constante e com níveis de oxigênio dissolvido altos, acima de 3,0 mg/l.

Para a avaliação de desempenho do sistema foram coletadas amostras na alimentação e nos efluentes dos reatores anaeróbio e aeróbio. As variáveis analisadas 
durante a operação do sistema com reatores anaeróbio e aeróbio em série, os pontos de amostragem, os métodos analíticos utilizados e as freqüências das análises são apresentadas na Tabela 4.7.

Tabela 4.7 - Variáveis analisadas, pontos de amostragem, métodos analíticos utilizados e freqüência de amostragem durante a operação do sistema com reatores anaeróbio e aeróbio de verticais de leito fixo em série.

\begin{tabular}{|c|c|c|c|}
\hline Variáveis analisadas & $\begin{array}{c}\text { Pontos de } \\
\text { amostragem }^{\mathrm{a}}\end{array}$ & Método analítico & $\begin{array}{c}\text { Freqüência } \\
\text { semanal }\end{array}$ \\
\hline Temperatura $\left({ }^{\circ} \mathrm{C}\right)$ & A e E1 & Termométrico & 5 vezes \\
\hline Oxigênio dissolvido $\left(\mathrm{mg} \mathrm{O}_{2} / \mathrm{l}\right)$ & A e E1 & Potenciométrico & 5 vezes \\
\hline $\mathrm{pH}$ & A, E1 e E2 & Potenciométrico & 5 vezes \\
\hline Alcalinidade $\left(\mathrm{mg} \mathrm{CaCO}_{3} / \mathrm{l}\right)$ & $\mathrm{A}, \mathrm{E} 1 \mathrm{e} \mathrm{E} 2$ & Titulométrico & 5 vezes \\
\hline Ácidos voláteis (mg HAc/l) & $\mathrm{A}, \mathrm{E} 1 \mathrm{e} \mathrm{E} 2$ & Titulométrico & 5 vezes \\
\hline DQO bruta $\left(\mathrm{mg} \mathrm{O}_{2} / 1\right)$ & $\mathrm{A}, \mathrm{E} 1 \mathrm{e} \mathrm{E} 2$ & Espectrofotométrico & 5 vezes \\
\hline DQO filtrada $\left(\mathrm{mg} \mathrm{O}_{2} / \mathrm{l}\right)$ & $\mathrm{A}, \mathrm{E} 1 \mathrm{e} \mathrm{E} 2$ & Espectrofotométrico & 5 vezes \\
\hline N-NTK (mg N/l) & $\mathrm{A}, \mathrm{E} 1 \mathrm{e} \mathrm{E} 2$ & Titulométrico & 5 vezes \\
\hline $\mathrm{N}-\mathrm{NH}_{4}{ }^{+}(\mathrm{mg} \mathrm{N} / \mathrm{l})$ & $\mathrm{A}, \mathrm{E} 1 \mathrm{e} \mathrm{E} 2$ & Titulométrico & 5 vezes \\
\hline $\mathrm{N}-\mathrm{NO}_{2}^{-}(\mathrm{mg} \mathrm{N} / \mathrm{l})$ & $\mathrm{E} 1 \mathrm{e} \mathrm{E} 2$ & Espectrofotométrico & 5 vezes \\
\hline $\mathrm{N}-\mathrm{NO}_{3}{ }^{-}(\mathrm{mg} \mathrm{N} / \mathrm{l})$ & E1 e E2 & Espectrofotométrico & 5 vezes \\
\hline $\mathrm{ST}(\mathrm{mg} \mathrm{ST} / \mathrm{l})$ & A e E1 & Gravimétrico & 5 vezes \\
\hline SST (mg SST/l) & A e E1 & Gravimétrico & 5 vezes \\
\hline SSV (mg SSV/l) & A e E1 & Gravimétrico & 5 vezes \\
\hline
\end{tabular}




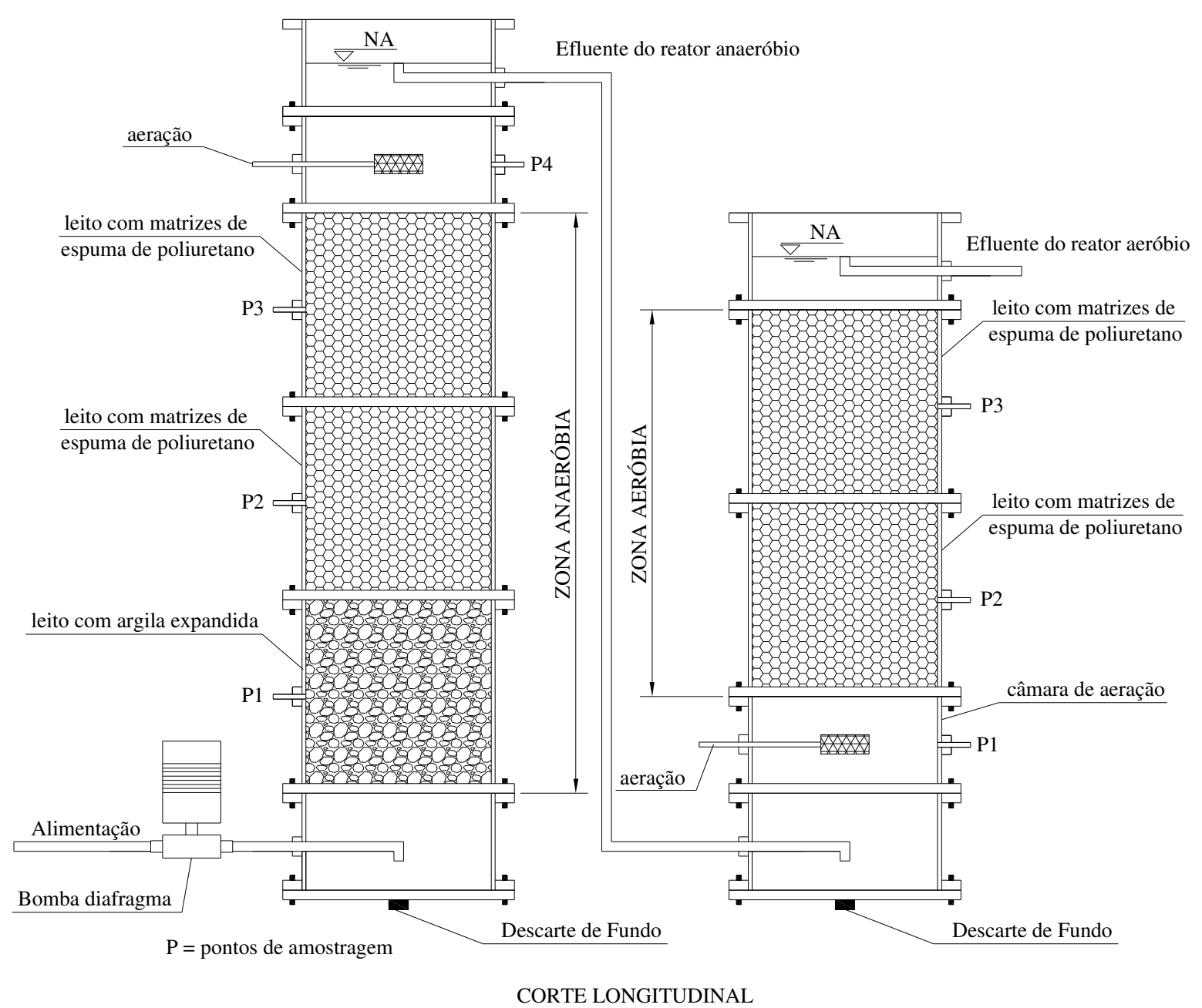

Figura 4.7 - Desenho esquemático dos reatores anaeróbio e aeróbio verticais de leito fixo em série.

\subsubsection{Etapa 4 - Reator combinado anaeróbio-aeróbio vertical de leito fixo com recirculação interna de efluente tratado}

Para esta etapa, os reatores anaeróbio e aeróbio foram novamente sobrepostos formando um único reator, conforme configuração da etapa 2 , estudando-se o comportamento do reator combinado anaeróbio-aeróbio vertical de leito fixo operando com recirculação interna de efluente tratado. Acoplou-se uma bomba diafragma, que succionava o efluente tratado da câmara de saída do reator e o recalcava para a metade do primeiro módulo anaeróbio, preenchido com suporte de argila expandida, conforme mostrado na Figura 4.8.

A recirculação interna tinha por objetivo promover a recirculação do nitrato formado na zona aeróbia para a zona anaeróbia do reator, forçando a sua desnitrificação 
pela utilização de doadores de elétrons presentes no início do processo, tais como, matéria orgânica afluente, ácidos orgânicos e metano formados no processo anaeróbio. Assim, mantendo-se a vazão de alimentação (Q) constante em 0,8 1/h, analogamente a etapa 2, com TDH total de $35 \mathrm{~h}$, baseado no volume útil do reator (21 h na zona anaeróbia e 14 h na zona aeróbia), operou-se o sistema com diferentes vazões de recirculação $\left(\mathrm{Q}_{\mathrm{R}}\right)$, com razão $\mathrm{Q}_{\mathrm{R}} / \mathrm{Q}$ iguais a 0,5, 1 e 3,5.

A aeração do módulo aeróbio foi mantida constante e com concentração de oxigênio dissolvido elevada, acima de 3,0 mg/l.

Para a avaliação de desempenho do sistema foram coletadas amostras na alimentação e no efluente tratado. As variáveis analisadas durante a operação do reator combinado anaeróbio-aeróbio com recirculação interna de efluente tratado, os pontos de amostragem, os métodos analíticos utilizados e as freqüências das análises são apresentadas na Tabela 4.8 .

Tabela 4.8 - Variáveis analisadas, pontos de amostragem, métodos analíticos utilizados e frequiência de amostragem durante a operação do reator combinado anaeróbio-aeróbio vertical de leito fixo com recirculação interna de efluente tratado.

\begin{tabular}{|c|c|c|c|}
\hline Variáveis analisadas & $\begin{array}{c}\text { Pontos de } \\
\text { amostragem }^{\mathrm{a}}\end{array}$ & Método analítico & $\begin{array}{c}\text { Freqüência } \\
\text { semanal }\end{array}$ \\
\hline Temperatura $\left({ }^{\circ} \mathrm{C}\right)$ & A e E & Termométrico & 5 vezes \\
\hline Oxigênio dissolvido $\left(\mathrm{mg} \mathrm{O}_{2} / \mathrm{l}\right)$ & A e E & Potenciométrico & 5 vezes \\
\hline $\mathrm{pH}$ & A e E & Potenciométrico & 5 vezes \\
\hline Alcalinidade $\left(\mathrm{mg} \mathrm{CaCO}_{3} / \mathrm{l}\right)$ & A e E & Titulométrico & 5 vezes \\
\hline Ácidos voláteis (mg HAc/l) & A e E & Titulométrico & 5 vezes \\
\hline DQO bruta $\left(\mathrm{mg} \mathrm{O}_{2} / 1\right)$ & A e E & Espectrofotométrico & 5 vezes \\
\hline DQO filtrada $\left(\mathrm{mg} \mathrm{O}_{2} / \mathrm{l}\right)$ & A e E & Espectrofotométrico & 5 vezes \\
\hline N-NTK (mg N/l) & A e E & Titulométrico & 5 vezes \\
\hline $\mathrm{N}-\mathrm{NH}_{4}{ }^{+}(\mathrm{mg} \mathrm{N} / \mathrm{l})$ & A e E & Titulométrico & 5 vezes \\
\hline $\mathrm{N}-\mathrm{NO}_{2}^{-}(\mathrm{mg} \mathrm{N} / \mathrm{l})$ & $\mathrm{E}$ & Espectrofotométrico & 5 vezes \\
\hline $\mathrm{N}-\mathrm{NO}_{3}{ }^{-}(\mathrm{mg} \mathrm{N} / \mathrm{l})$ & $\mathrm{E}$ & Espectrofotométrico & 5 vezes \\
\hline $\mathrm{ST}(\mathrm{mg} \mathrm{ST} / \mathrm{l})$ & A e $E$ & Gravimétrico & 5 vezes \\
\hline SST (mg SST/1) & A e E & Gravimétrico & 5 vezes \\
\hline SSV (mg SSV/l) & A e $E$ & Gravimétrico & 5 vezes \\
\hline
\end{tabular}

${ }^{\mathrm{a}} \mathrm{A}=$ Alimentação (afluente); $\mathrm{E}=$ Efluente tratado. 


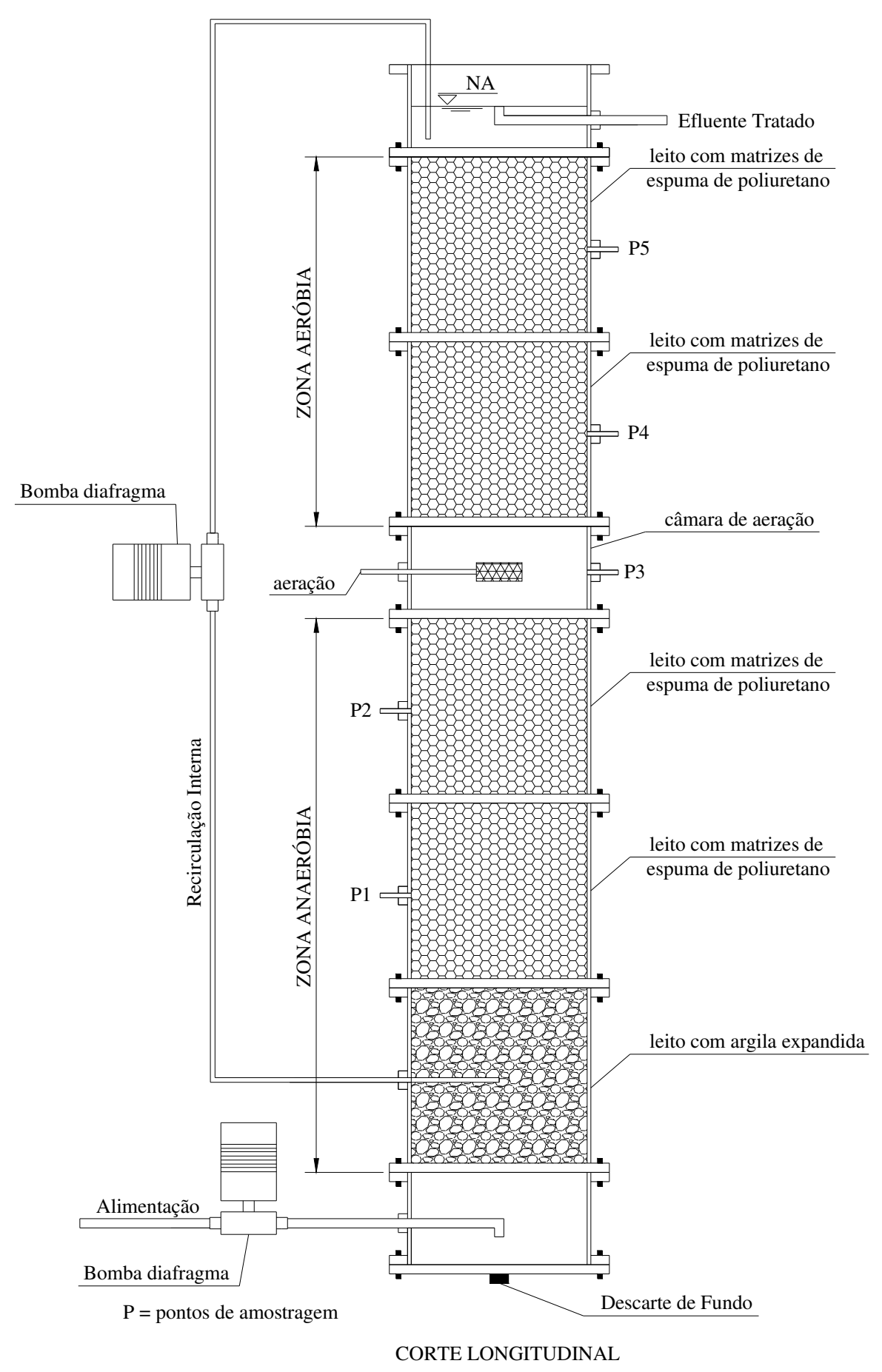

Figura 4.8 - Desenho esquemático do reator combinado anaeróbio-aeróbio vertical de leito fixo com recirculação interna de efluente tratado. 


\subsubsection{Resumo das etapas experimentais}

Na Tabela 4.9 é apresentado um resumo das etapas experimentais do reator vertical de leito fixo, contendo o tempo de operação, a vazão de alimentação (Q), a razão de recirculação $(\mathrm{R})$ e o tempo de detenção hidráulica aplicados para cada etapa.

Tabela 4.9 - Resumo das etapas experimentais do reator vertical de leito fixo.

\begin{tabular}{cccccccc}
\hline Etapa & Tempo de & $\mathbf{Q}$ & $\mathbf{R}$ & \multicolumn{3}{c}{ TDH (h) } \\
\cline { 5 - 8 } experimental & \begin{tabular}{c} 
operação $(\mathbf{d})$ \\
\cline { 5 - 7 }
\end{tabular} & $(\mathbf{l} / \mathbf{h})$ & $\left(\mathbf{Q}_{\mathbf{r}} / \mathbf{Q}\right)$ & Anaeróbio & Aeróbio & Total \\
\hline \multirow{2}{*}{$\mathbf{1}$} & 20 & 1,5 & - & 11 & - & 11 \\
& 34 & 1,0 & - & 17 & - & 17 \\
& 20 & 0,8 & - & 21 & - & 21 \\
& 35 & 0,7 & - & 24 & - & 24 \\
\hline $\mathbf{2}$ & 90 & 0,8 & - & 21 & 14 & 35 \\
\hline $\mathbf{3}$ & 20 & 0,8 & - & 21 & 14 & 35 \\
\hline \multirow{4}{*}{$\mathbf{4}$} & 19 & 0,8 & 0,5 & 21 & 14 & 35 \\
& 34 & 0,8 & 1,0 & 21 & 14 & 35 \\
& 23 & 0,8 & 0,0 & 21 & 14 & 35 \\
& 25 & 0,8 & 3,5 & 21 & 14 & 35 \\
\hline
\end{tabular}





\section{Resultados e Discussão}

Como mencionado em Material e Métodos, a investigação experimental foi realizada em quatro etapas principais. Na primeira, estudou-se o comportamento do reator vertical de leito fixo operando unicamente em condição anaeróbia. Posteriormente, na segunda etapa, módulos aeróbios foram acoplados ao reator, avaliando-se o comportamento do mesmo operando em condição combinada anaeróbiaaeróbia. Na terceira etapa, os módulos anaeróbios e aeróbios foram separados em dois reatores distintos e verificou-se o desempenho do sistema operando com os reatores anaeróbio e aeróbio em série. Por fim, na quarta etapa, os módulos anaeróbios e aeróbios foram reacoplados e avaliou-se o desempenho do reator combinado anaeróbioaeróbio operando com recirculação de efluente tratado. Neste capítulo serão apresentados os resultados e discussões referentes às quatro etapas de operação e aos exames microbiológicos realizados ao final do trabalho experimental.

\subsection{ETAPA 1 - REATOR ANAERÓBIO VERTICAL DE LEITO FIXO}

O reator anaeróbio de leito fixo foi posto em marcha por meio de aumento gradual das concentrações de matéria orgânica e nitrogênio, aumentando-se a concentração afluente de água residuária de acordo com a resposta do sistema. Esse período teve o objetivo de adaptar a biomassa anaeróbia ao efluente da Ajinomoto, finalizando-se após 30 dias de operação. A partir do $31^{\circ}$ dia, iniciou-se a operação do reator anaeróbio propriamente dita, com a alimentação do sistema contendo $100 \%$ de água residuária. A vazão afluente foi mantida em 1,5 1/h, com tempo de detenção hidráulica (TDH) de 11 horas, com base no volume útil do reator $(17$ 1). Nesta condição o reator foi operado por 20 dias, obtendo eficiências médias na remoção de DQO 
(demanda química de oxigênio) e SST (sólidos suspensos totais) iguais a $43 \pm 9 \%$ e 69 $\pm 13 \%$, respectivamente. A eficiência média do sistema na remoção do nitrogênio orgânico (N-org), ou seja, na amonificação do N-org afluente, foi de $61 \pm 15 \%$ durante este período.

No $50^{\circ}$ dia de operação diminuiu-se a vazão de alimentação para $1,0 \mathrm{l} / \mathrm{h}$, passando de $11 \mathrm{~h}$ para $17 \mathrm{~h}$ o tempo de detenção hidráulica no reator. Operou-se o sistema nessa condição por 34 dias e as eficiências médias alcançadas na remoção de DQO, SST e N-org foram de $60 \pm 9 \%, 71 \pm 15 \%$ e $75 \pm 12 \%$, respectivamente.

No intervalo de tempo entre os dias 84 e 103 o reator foi operado com vazão afluente de 0,8 1/h e TDH igual a 21 h. Para esses 20 dias de operação, as eficiências médias do reator ficaram em $70 \pm 6 \%$ na remoção de DQO, $70 \pm 13 \%$ na remoção de SST e $71 \pm 10 \%$ na remoção do N-org.

Entre os dias 104 e 135, a fábrica da Ajinomoto realizou uma parada programada para manutenção e limpeza de seus equipamentos, conseqüentemente, a geração de efluente foi interrompida e o reator ficou sem alimentação durante esse período. Ao se retomar a atividade da fábrica, iniciou-se novamente a operação do sistema com vazão afluente de 0,7 1/h e TDH igual a $24 \mathrm{~h}$, permanecendo nesta condição até o $169^{\circ}$ dia, finalizando a operação do reator anaeróbio. Durante essa fase final, as eficiências médias de remoção de DQO, SST e N-org foram de $58 \pm 6 \%, 71 \pm$ $10 \%$ e $70 \pm 10 \%$, respectivamente.

Nas Figuras 5.1, 5.2 e 5.3 são apresentados, respectivamente, os perfis de eficiência na remoção de DQO, SST e N-org ao longo do tempo de operação do reator anaeróbio vertical de leito fixo. 


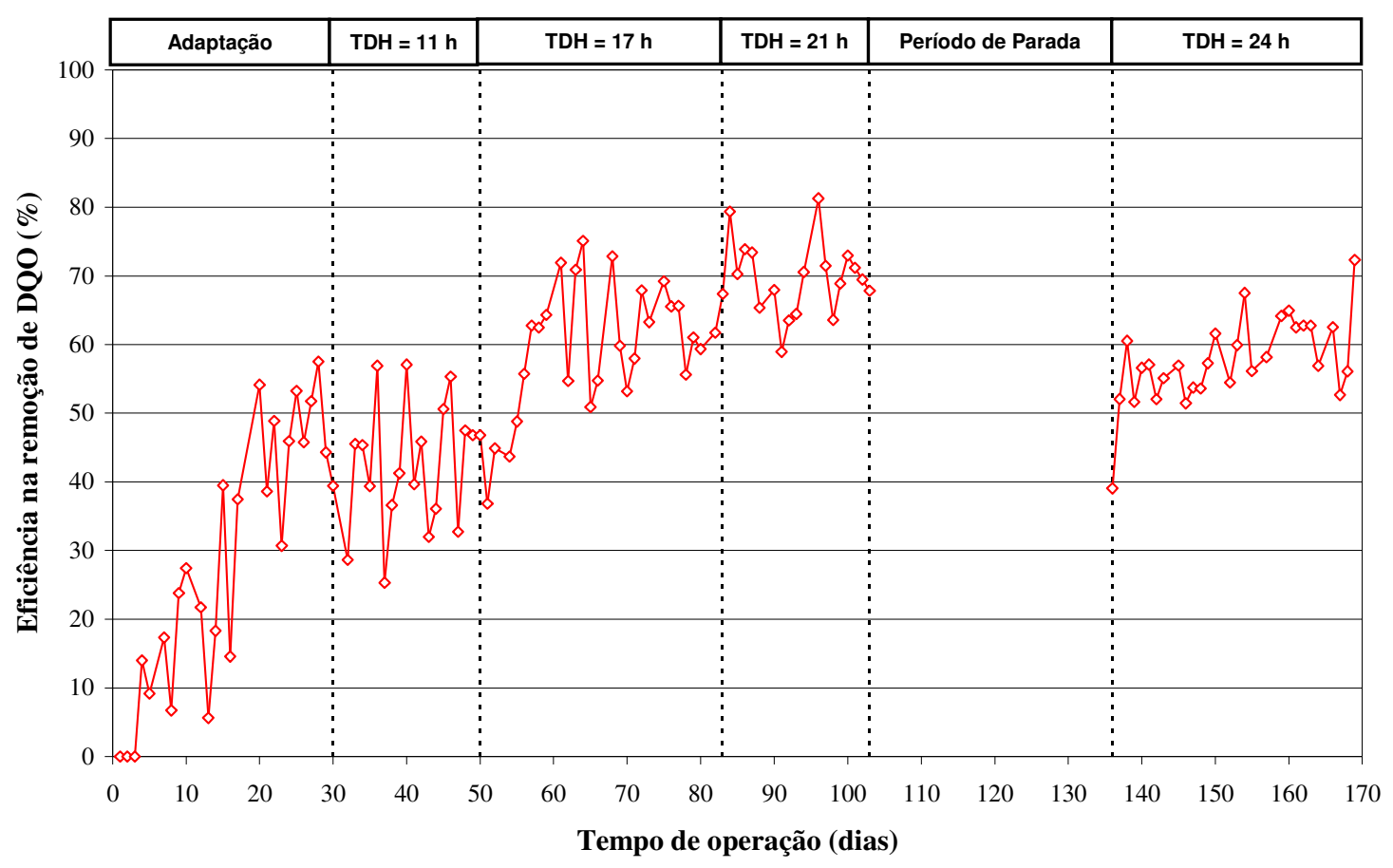

Figura 5.1 - Eficiência na remoção de DQO ao longo do tempo de operação do reator anaeróbio vertical de leito fixo.

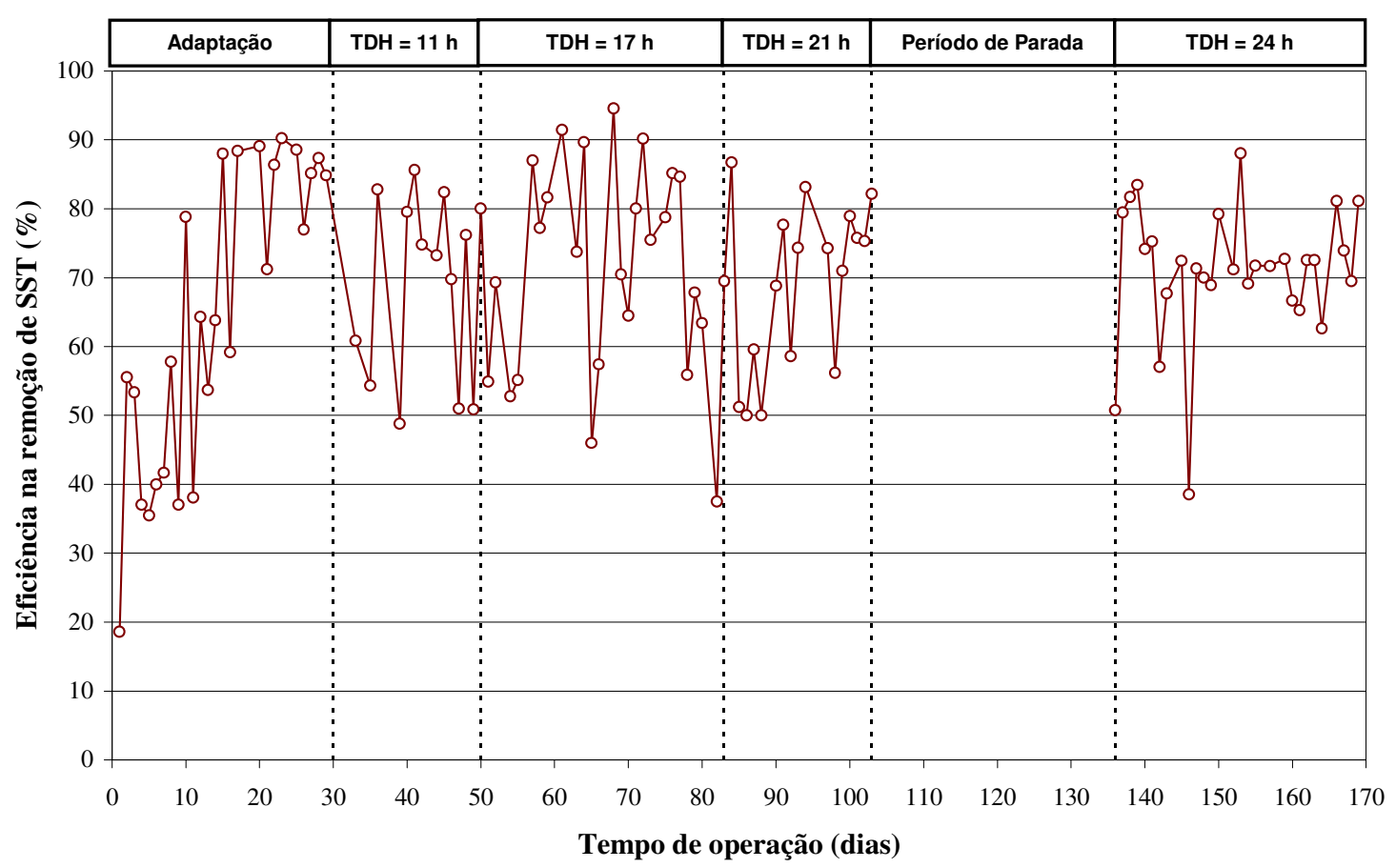

Figura 5.2 - Eficiência na remoção de SST ao longo do tempo de operação do reator anaeróbio vertical de leito fixo. 


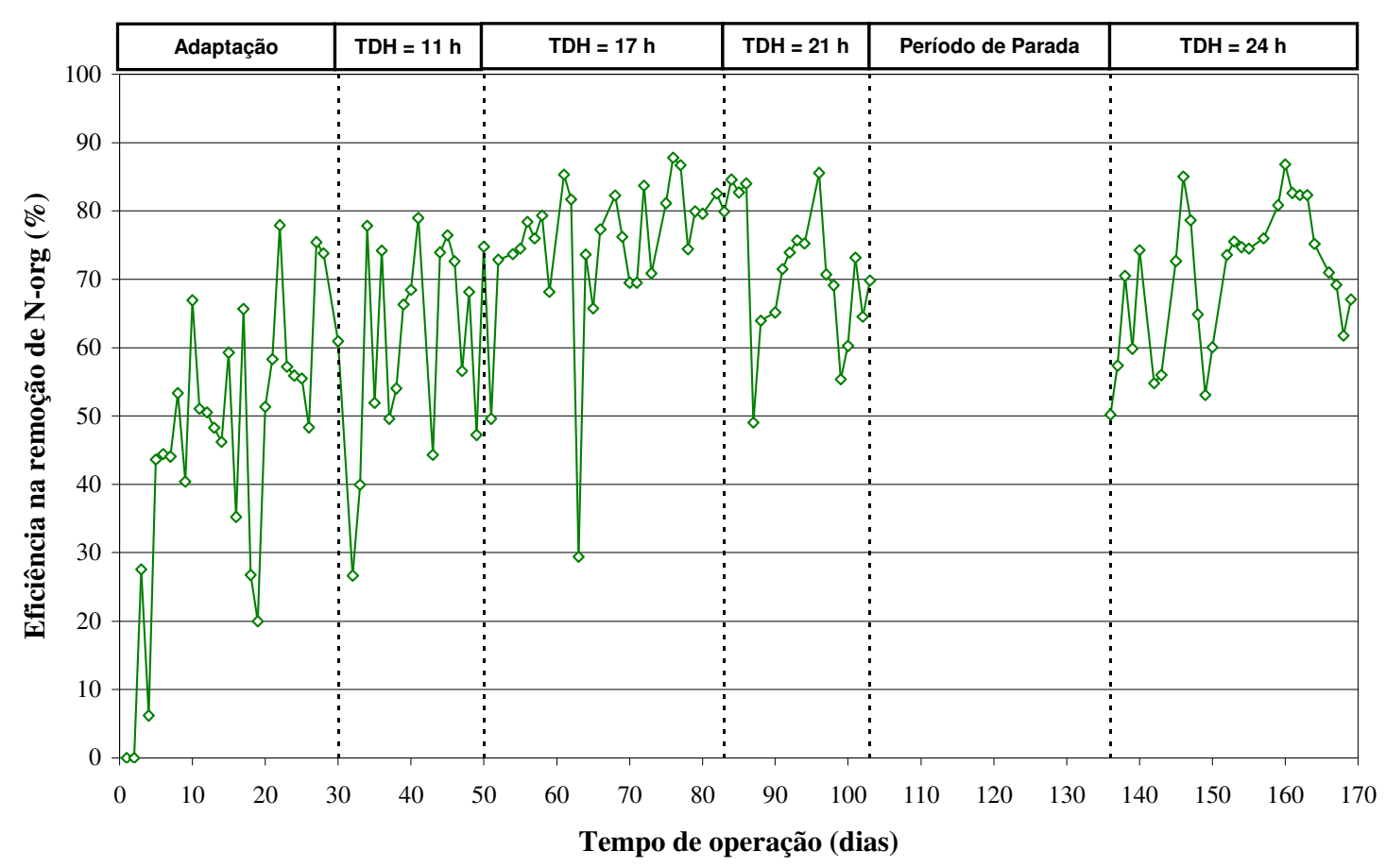

Figura 5.3 - Eficiência na remoção de N-org ao longo do tempo de operação do reator anaeróbio vertical de leito fixo.

Devido às características da água residuária da Ajinomoto, a DQO afluente variou significativamente ao longo da operação do reator, tendo valor médio de $1329 \pm$ $147 \mathrm{mg} / \mathrm{l}$. Apesar destas oscilações, o sistema mostrou-se robusto aos choques de carga durante toda a operação, apresentando valores médios de DQO efluente de $711 \pm 129$ $\mathrm{mg} / \mathrm{l}, 507 \pm 111 \mathrm{mg} / \mathrm{l}, 419 \pm 69 \mathrm{mg} / \mathrm{l}$ e $585 \pm 84 \mathrm{mg} / \mathrm{l}$, respectivamente, para TDH de 11 h, 17 h, 21 h e 24 h. Na Figura 5.4 é apresentado o perfil de DQO durante a operação do reator anaeróbio de leito fixo.

Na Figuras 5.5 é apresentado o gráfico Box-plot de distribuição dos resultados de DQO para cada TDH aplicado. A representação Box-plot é uma ferramenta estatística que possibilita a visualização da distribuição dos pontos amostrados, apresentando no box a mediana (50\%), o primeiro quartil (25\%) e o terceiro quartil (75\%). São discriminados também os percentis $90 \%$ e 10\%, além dos valores máximos e mínimos da distribuição. Para esse tipo de representação pode-se afirmar que quanto maior o comprimento do box interior maior será a heterogeneidade da amostra, conseqüentemente, maior será o desvio padrão. 


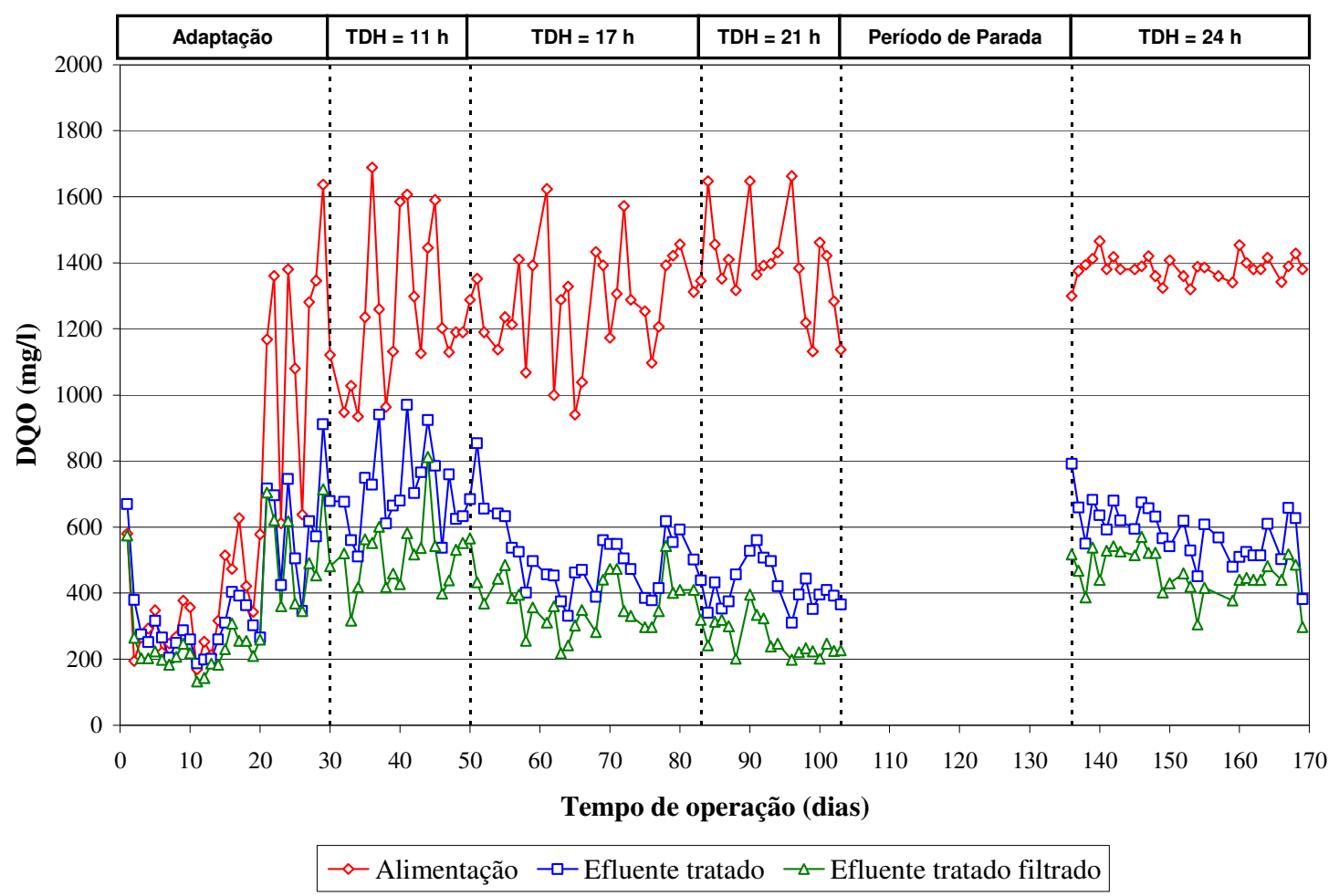

Figura 5.4 -DQO na alimentação, no efluente tratado e no efluente tratado filtrado do reator anaeróbio de leito fixo ao longo do tempo de operação.

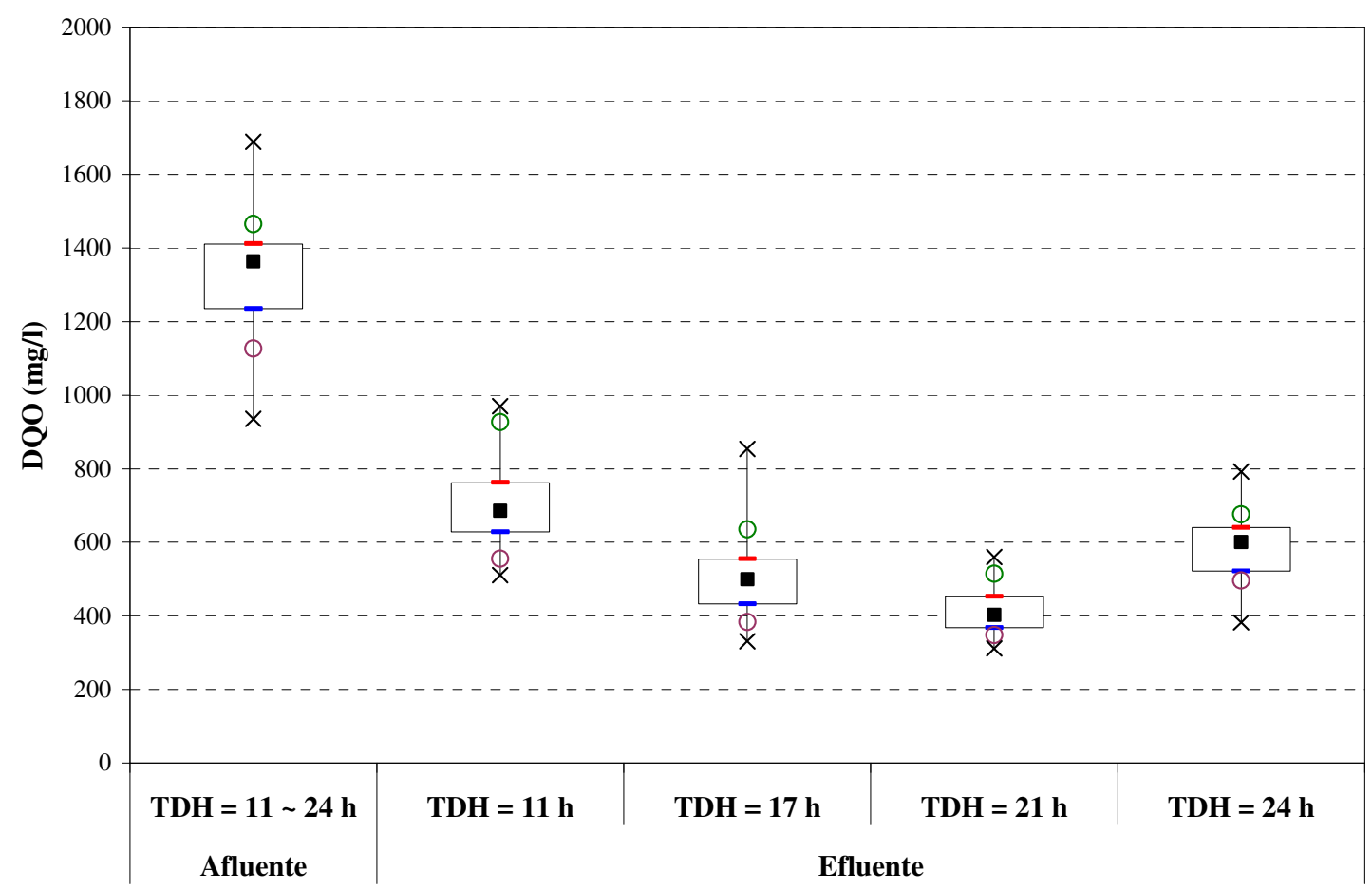

-25\% -50\% ○ 90\% O 10\% × Mín × Máx -75\%

Figura 5.5 - Gráfico Box-plot de distribuição dos resultados de DQO afluente e efluente para cada TDH aplicado. 
Esperava-se que a maior eficiência na remoção de DQO fosse alçada para TDH igual a 24 horas, contudo isso não foi confirmado sendo que a melhor condição operacional foi conseguida para TDH igual a 21 horas. A principal hipótese levantada para explicar esse fenômeno foi o desbalanceamento da biomassa anaeróbia durante o período de parada do reator, fazendo com que houvesse o predomínio do crescimento das bactérias acetogênicas perante as arquéias metanogênicas.

Essa hipótese foi evidenciada por meio da análise dos gráficos das Figuras 5.6 e 5.7, nos quais são apresentados os valores de $\mathrm{pH}$ e alcalinidade a bicarbonato durante a operação do reator anaeróbio de leito fixo. Antes da parada da fábrica, os valores de $\mathrm{pH}$ do efluente tratado mantinham-se em patamar neutro, entre 7,0 e 7,5, com alcalinidade ligeiramente superior à alcalinidade da alimentação. Com a retomada da alimentação do sistema, a partir do $136^{\circ}$ dia, o $\mathrm{pH}$ do efluente tratado apresentou tendência de queda, atingindo valor mínimo de 5,1 no $141^{\circ}$ dia. A alcalinidade efluente também decresceu bruscamente, mantendo valores próximos de zero entre os dias 141 e 145 .

Outro indicador do desbalanceamento da biomassa anaeróbia foi o aumento da concentração de ácidos voláteis totais no efluente tratado, passando de cerca de $100 \mathrm{mg}$ HAc/l antes da parada para cerca de $250 \mathrm{mg} \mathrm{HAc/l}$ após a parada, como pode ser visto na Figura 5.8. Assim, temendo a falência do sistema pelo acúmulo de ácidos propiônico e butírico no reator, a partir do $146^{\circ}$ dia de operação, iniciou-se processo de alcalinização do afluente adicionando-se $\mathrm{NaHCO}_{3}$ no tanque de alimentação. A partir deste dia, a alcalinidade e o pH efluente aumentaram e o sistema apresentou tendência de melhora. 


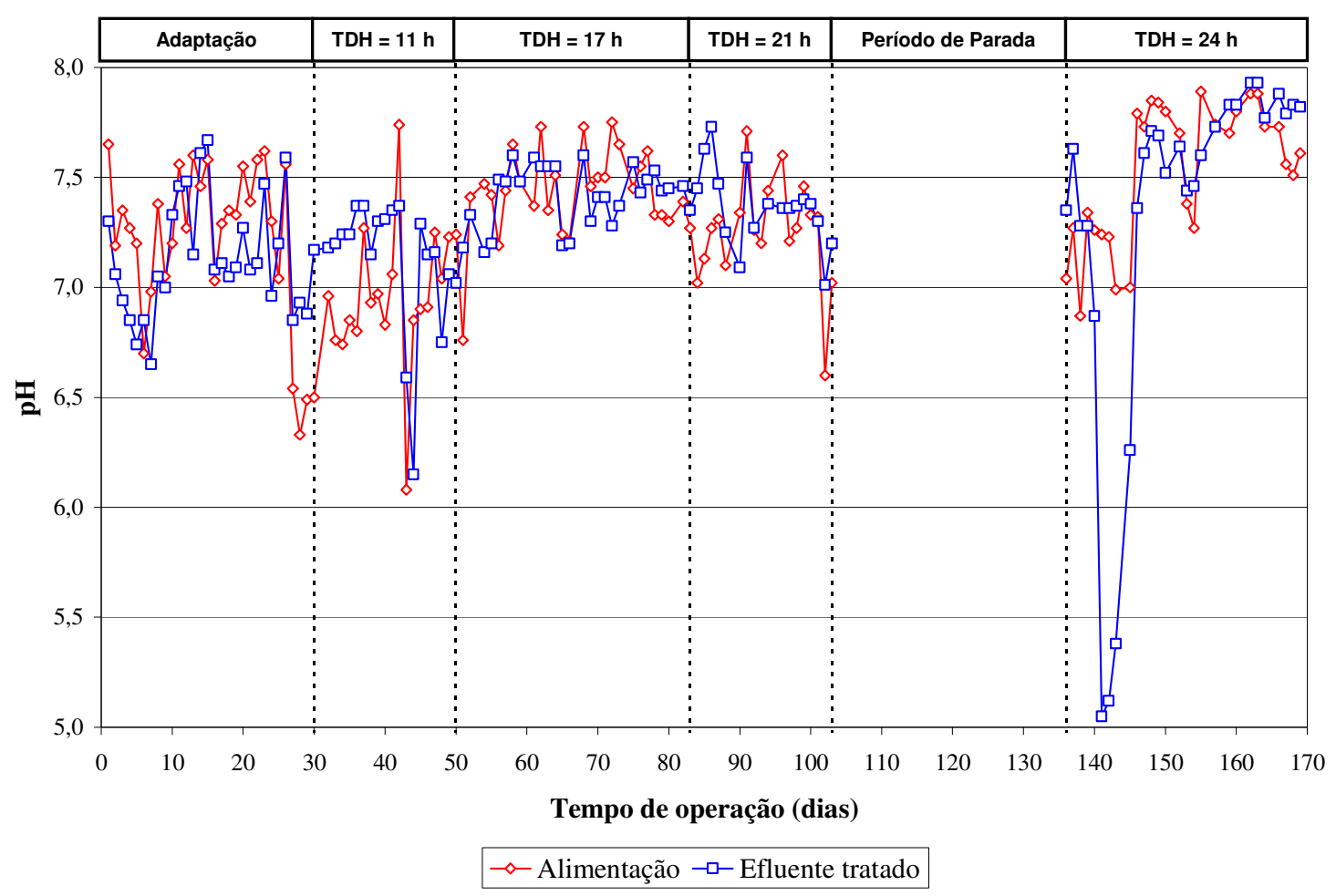

Figura 5.6 - pH na alimentação e no efluente tratado do reator anaeróbio de leito fixo ao longo do tempo de operação.

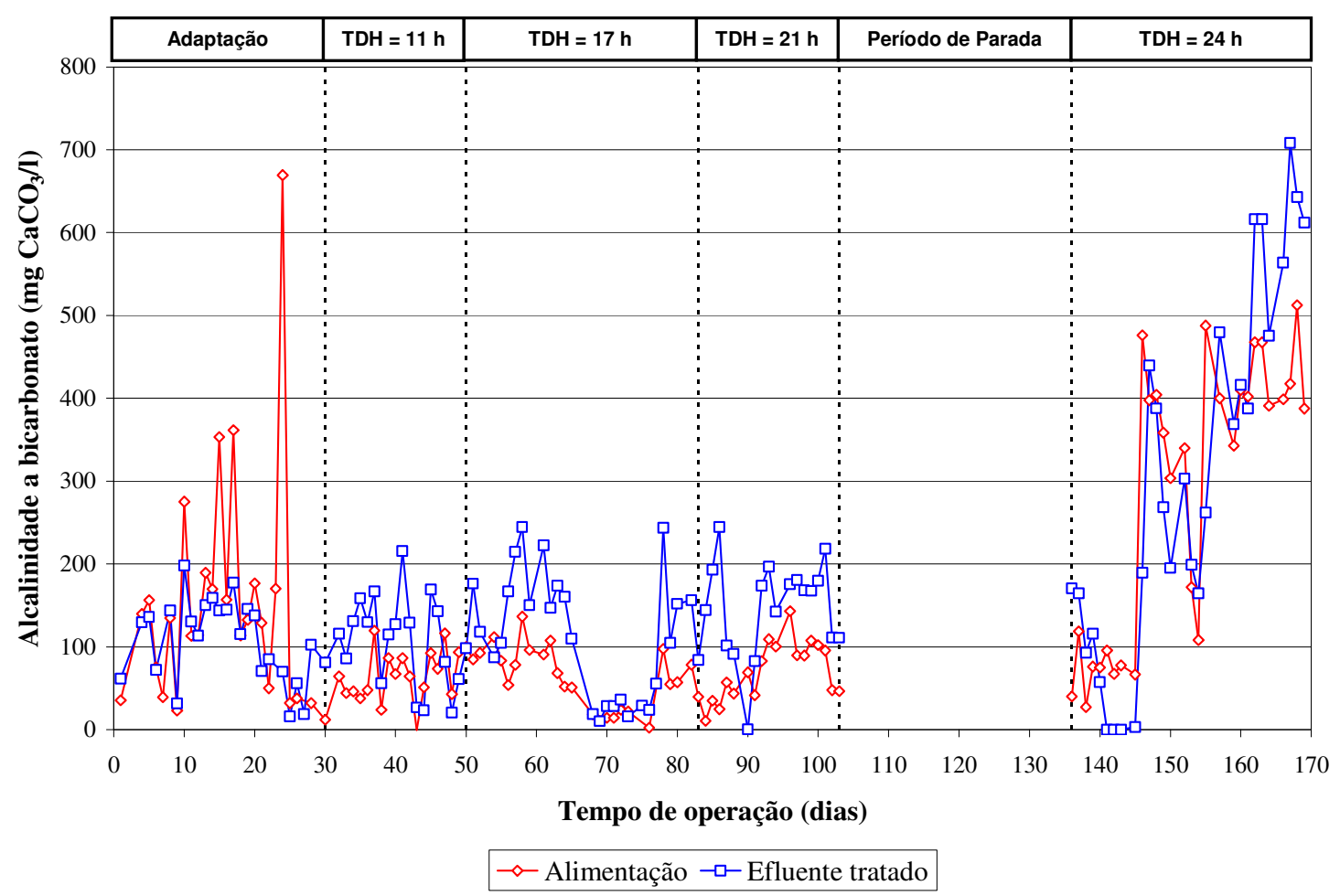

Figura 5.7 - Alcalinidade a bicarbonato na alimentação e no efluente tratado do reator anaeróbio de leito fixo ao longo do tempo de operação. 


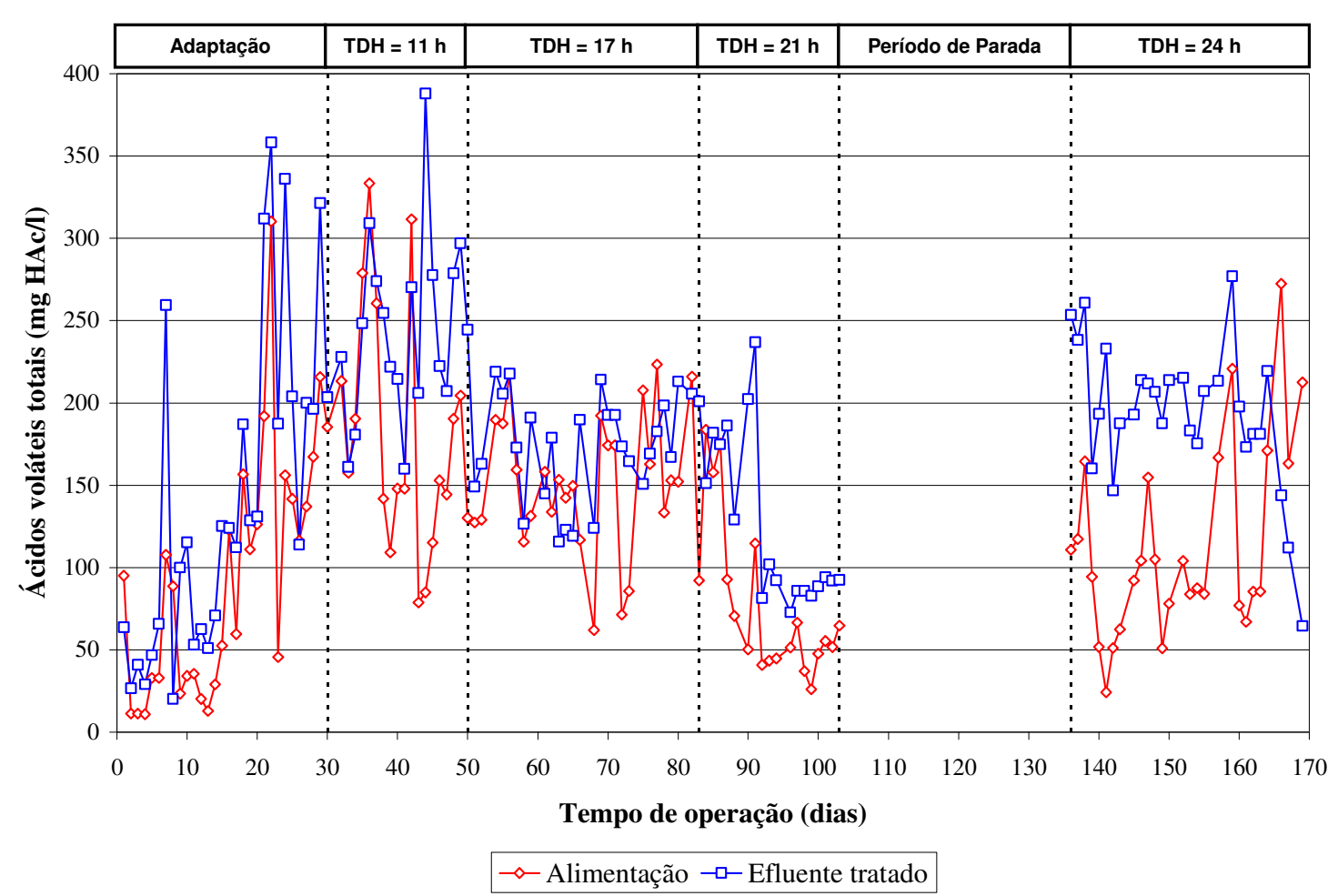

Figura 5.8 - Ácidos voláteis totais na alimentação e no efluente tratado do reator anaeróbio de leito fixo ao longo do tempo de operação.

Os valores de DQO filtrada no efluente do reator anaeróbio apresentaram-se relativamente baixos quando comparados com os valores obtidos para DQO bruta (Figura 5.4), com demandas médias de $513 \pm 105 \mathrm{mg} / \mathrm{l}, 367 \pm 79 \mathrm{mg} / \mathrm{l}, 261 \pm 56 \mathrm{mg} / \mathrm{l} \mathrm{e}$ $460 \pm 68 \mathrm{mg} / \mathrm{l}$, respectivamente, para TDH de 11 h, 17 h, 21 h e 24 h. Essa diferença mostra que grande parte da DQO efluente, cerca de $28 \%$ em média, era proveniente do escape de sólidos em suspensão do sistema.

Os valores médios de concentração de SST na alimentação e no efluente tratado do reator foram de $210 \pm 113 \mathrm{mg} / \mathrm{l}$ e $59 \pm 28 \mathrm{mg} / \mathrm{l}$, respectivamente, apresentando relação média entre sólidos em suspensão totais e sólidos em suspensão voláteis (SST/SSV) superior a 92\% para ambos os pontos. Na Figura 5.9 são apresentados os valores de concentração de SST na alimentação e no efluente tratado do reator anaeróbio de leito fixo ao longo do tempo de operação. 


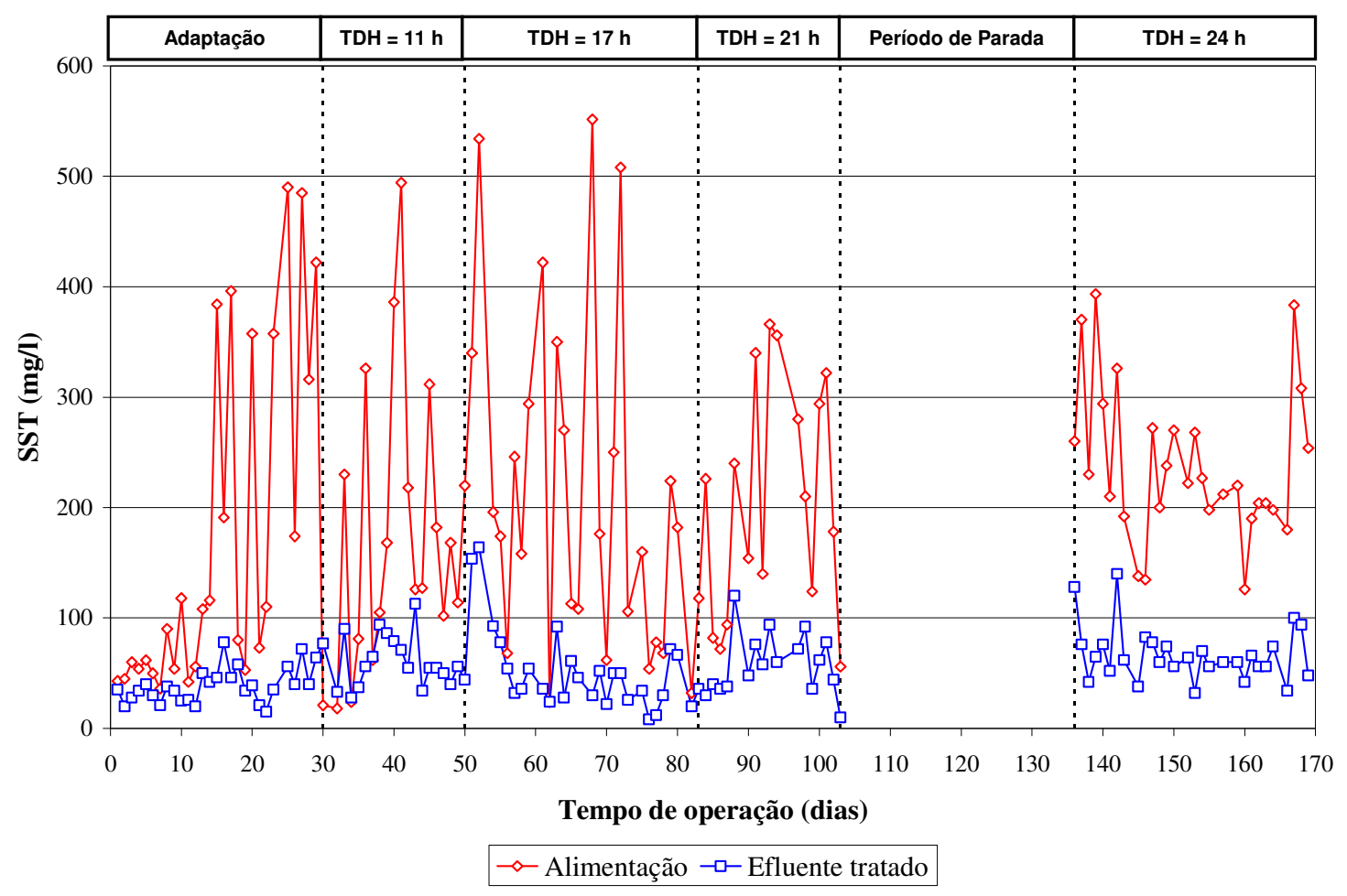

Figura 5.9 - SST na alimentação e no efluente tratado do reator anaeróbio de leito fixo ao longo do tempo de operação.

A concentração média de nitrogênio total (NT) na alimentação do reator anaeróbio foi de $130 \pm 27 \mathrm{mg} \mathrm{N} / \mathrm{l}$, sendo 67\% na forma orgânica (N-org) e 33\% na forma amoniacal (N-amoniacal). Após o tratamento anaeróbio, a maior fração de nitrogênio apresentou-se na forma amoniacal (78\%) com valor médio de $94 \pm 19 \mathrm{mg}$ $\mathrm{N} / \mathrm{l}$, enquanto que a concentração de nitrogênio orgânico apresentou-se baixa, com valor médio de $27 \pm 11 \mathrm{mg} \mathrm{N} / 1$, embora houvesse arraste de sólidos em suspensão do sistema. Na Figura 5.10 é apresentada a variação da concentração de nitrogênio total na alimentação e no efluente tratado do reator anaeróbio de leito fixo. 


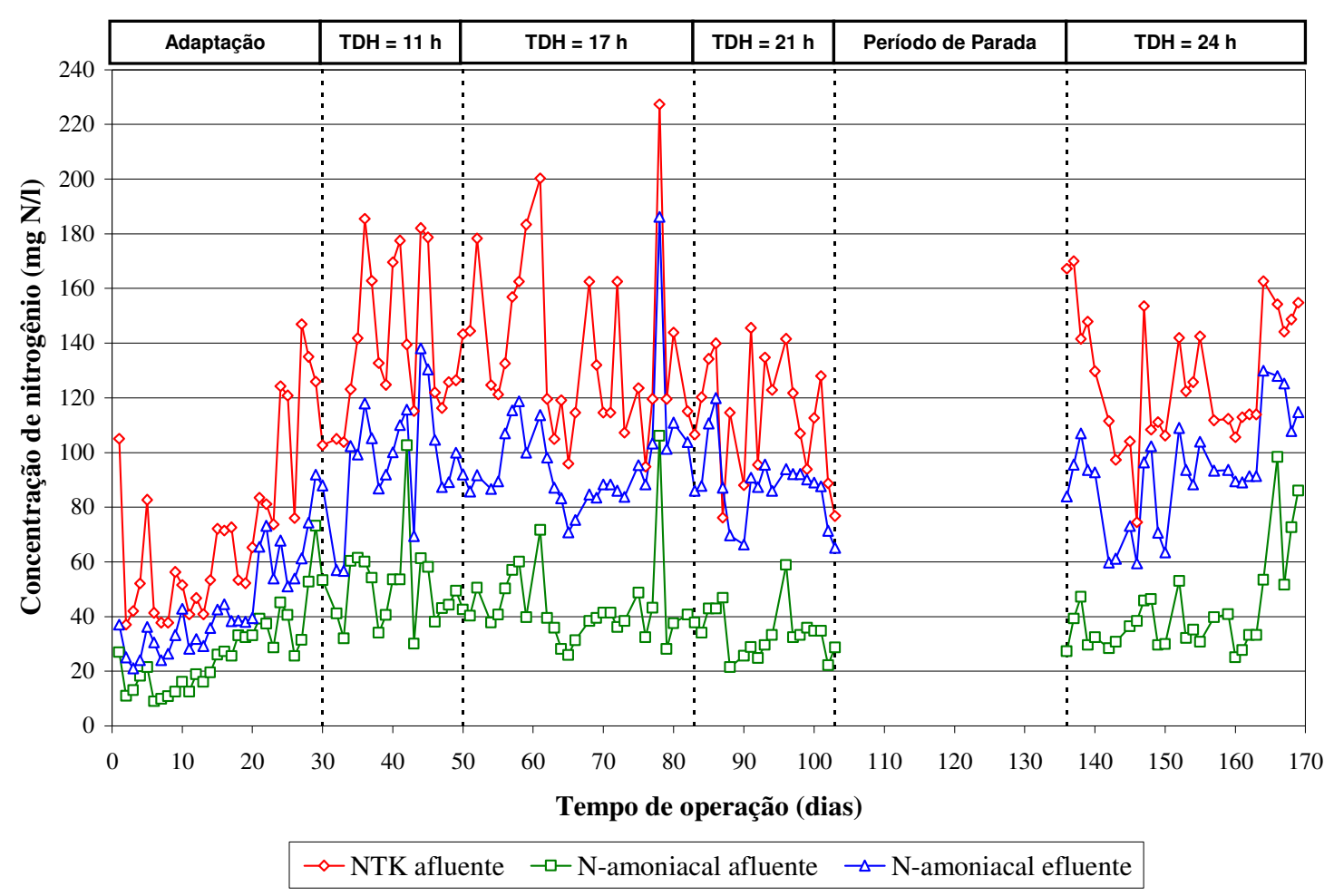

Figura 5.10 - Concentração de nitrogênio na alimentação e no efluente tratado do reator anaeróbio de leito fixo ao longo do tempo de operação.

Para efeito de dimensionamento e aumento de escala do reator anaeróbio de leito fixo, relacionou-se a eficiência de remoção de DQO ( $\left.\mathrm{E}_{\mathrm{DQO}}\right)$ com o tempo de detenção hidráulica (TDH) e a carga orgânica volumétrica aplicada (COV), conforme apresentado na Tabela 5.1. Para o cálculo de TDH e COV considerou-se o volume útil do reator (17 1), conforme discutido no item 4.8.1 de Material e Métodos.

Na Figura 5.11 é apresentado o perfil de carga orgânica volumétrica (COV) na alimentação do reator anaeróbio de leito fixo ao longo do tempo de operação, de acordo com o tempo de detenção hidráulica aplicado. 
Tabela 5.1 - Resultados médios de DQO afluente, DQO efluente e de eficiência na remoção de $\mathrm{DQO}\left(\mathrm{E}_{\mathrm{DQO}}\right)$ em função do tempo de detenção hidráulica (TDH) e da carga orgânica volumétrica (COV) aplicada.

\begin{tabular}{ccccc}
\hline Parâmetros / TDH & $\mathbf{1 1 ~ h}$ & $\mathbf{1 7} \mathbf{~ h}$ & $\mathbf{2 1 ~ h}$ & $\mathbf{2 4} \mathbf{~ h}$ \\
\hline COV $\left(\mathrm{kg}\right.$ DQO. $\left.\mathrm{m}^{-3} \cdot \mathrm{d}^{-1}\right)$ & $3,37 \pm 0,62$ & $1,81 \pm 0,23$ & $1,58 \pm 0,17$ & $1,37 \pm 0,04$ \\
DQO afluente $\left(\mathrm{mg} \mathrm{O}_{2} / \mathrm{l}\right)$ & $1255 \pm 232$ & $1281 \pm 164$ & $1396 \pm 153$ & $1384 \pm 37$ \\
DQO efluente $\left(\mathrm{mg} \mathrm{O}_{2} / \mathrm{l}\right)$ & $711 \pm 129$ & $507 \pm 111$ & $419 \pm 69$ & $585 \pm 84$ \\
E $_{\text {DQO }}(\%)$ & $43 \pm 9$ & $60 \pm 9$ & $70 \pm 6$ & $58 \pm 6$ \\
\hline
\end{tabular}

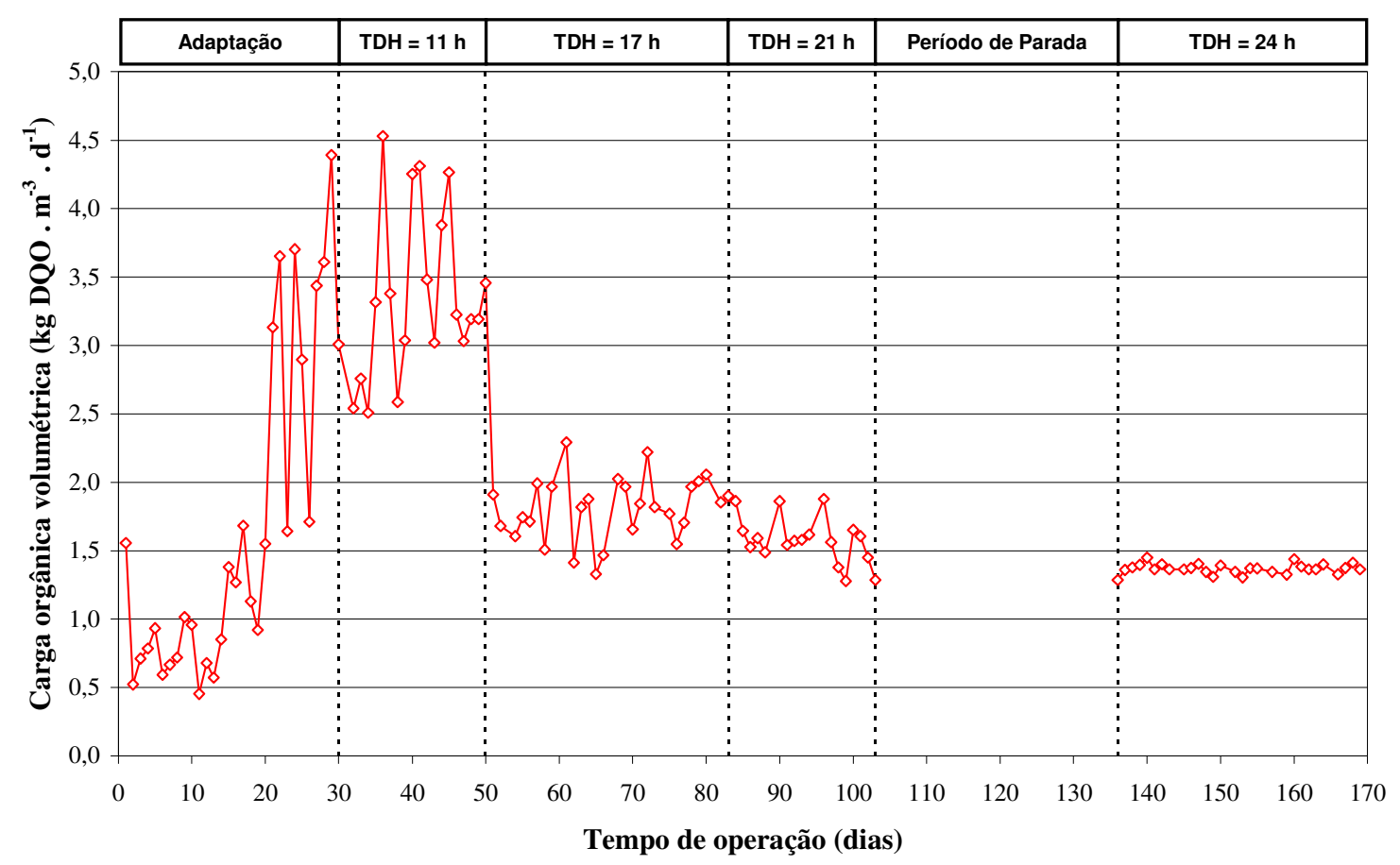

Figura 5.11 - Carga orgânica volumétrica (COV) na alimentação do reator anaeróbio de leito fixo ao longo do tempo de operação, para cada TDH aplicado.

$\mathrm{O}$ ajuste das curvas de $\mathrm{E}_{\mathrm{DQO}}$ em função do TDH e da COV, apresentado na Figura 5.12, foi realizado por meio de regressão não-linear para curva do tipo potência $\left(y=a \cdot x^{b}\right)$ utilizando software Microsoft Excel ${ }^{\circledR}$, cujas expressões são mostradas nas Equações 5.1 e 5.2. A utilização de regressão não linear para o ajuste das curvas permitiu que os valores de $\mathrm{E}_{\mathrm{DQO}}$ ficassem limitados em $100 \%$, mesmo para baixos valores de TDH. Por representarem um período de instabilidade do reator anaeróbio, os resultados referentes à operação com TDH igual a 24 horas foram desconsiderados na análise de desempenho do sistema. 
Considerando TDH entre 11 e 21 horas e temperatura de $30 \pm 1^{\circ} \mathrm{C}$, a correlação entre a eficiência de remoção de DQO $\left(\mathrm{E}_{\mathrm{DQO}}\right)$ e o TDH obedeceu tendência descrita pela Equação 5.1, com coeficiente de correlação $\left(R^{2}\right)$ igual a 0,99 :

$$
E_{D Q O}=100-643,88 .(T D H)^{-0,99}
$$

Analogamente, a correlação entre a eficiência de remoção de DQO ( $\left.\mathrm{E}_{\mathrm{DQO}}\right)$ e a carga orgânica volumétrica $(\mathrm{COV})$, para COV entre 1,58 e 3,37 kg DQO.m $\mathrm{m}^{-3} \cdot \mathrm{d}^{-1} \mathrm{e}$ temperatura de $30 \pm 1^{\circ} \mathrm{C}$ obedeceu tendência descrita pela Equação 5.2, com coeficiente de correlação $\left(\mathrm{R}^{2}\right)$ igual a 0,92 :

$$
E_{D Q O}=100-23,19 .(C O V)^{0,76}
$$

Nas Equações 5.1 e 5.2, $\mathrm{E}_{\mathrm{DQO}}$ está expressa em termos percentuais [\%], TDH em $\mathrm{h}$ e $\mathrm{COV}$ em $\mathrm{kg}$ DQO. $\mathrm{m}^{-3} \cdot \mathrm{d}^{-1}$. Estas equações só têm validade para a faixa estudada, portanto, não devem ser extrapoladas.
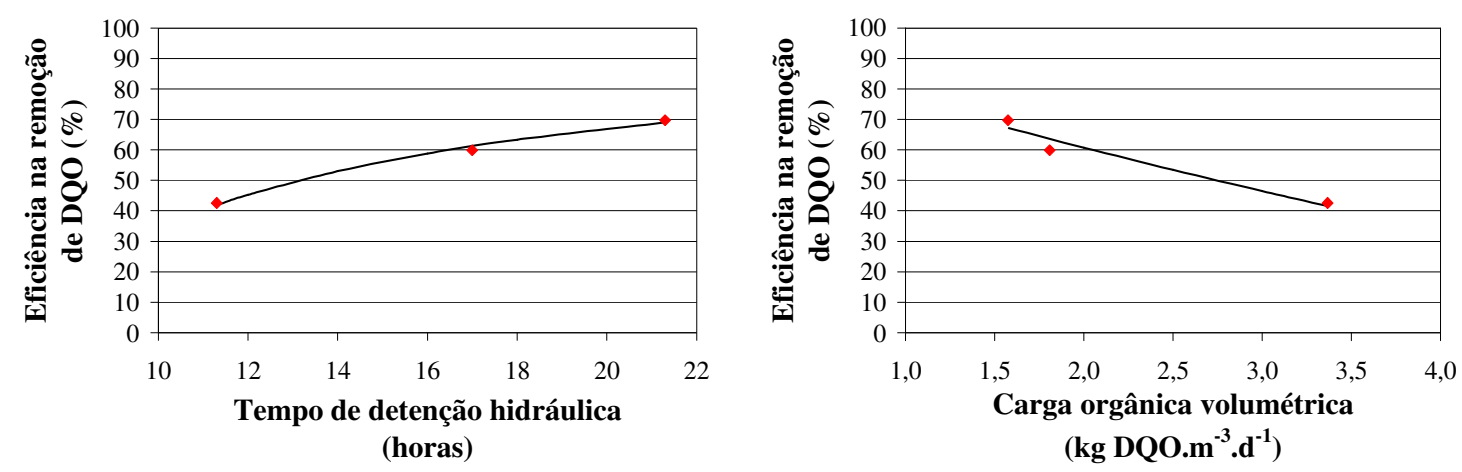

Figura 5.12 - Curvas ajustadas (Equações 5.1 e 5.2) que relacionam a eficiência média de remoção de DQO com o tempo de detenção hidráulica e a carga orgânica volumétrica.

Comparado com outros sistemas anaeróbios aplicados ao tratamento de água residuária industrial citados na literatura (METCALF \& EDDY, 2003), o reator anaeróbio vertical de leito fixo apresentou desempenho satisfatório no tratamento do efluente da fábrica da Ajinomoto, obtendo seu melhor desempenho para TDH igual a 21 h com $70 \pm 6 \%$ de eficiência na remoção de DQO. 
Na Tabela 5.2 são apresentados exemplos de aplicação de reatores anaeróbios de leito fixo no tratamento de algumas águas residuárias industriais e os resultados alcançados para o reator anaeróbio vertical de leito fixo.

Tabela 5.2 - Parâmetros operacionais e performance de sistemas anaeróbios de leito fixo tratando água residuária industrial.

\begin{tabular}{|c|c|c|c|c|}
\hline Água residuária & $\begin{array}{c}\text { Temperatura } \\
\left({ }^{\circ} \mathrm{C}\right)\end{array}$ & $\begin{array}{c}\text { COV } \\
\left(k^{\prime} \text { DQO.m } m^{-3} \cdot d^{-1}\right)\end{array}$ & $\begin{array}{c}\text { TDH } \\
\text { (h) }\end{array}$ & $\begin{array}{r}\mathbf{E}_{\mathrm{DQO}} \\
(\%)\end{array}$ \\
\hline
\end{tabular}

\section{Reator anaeróbio de leito fixo de fluxo descendente ${ }^{\mathrm{a}}$}

$\begin{array}{lcccc}\text { Indústria cítrica } & 38 & 1-6 & 24-144 & 40-80 \\ \text { Laticínio } & 35 & 5-22 & 2-8 & 92-97 \\ \text { Cervejaria } & 35 & 20 & 1-2 & 76 \\ \text { Melaço } & 35 & 2-13 & 14-112 & 56-80 \\ \text { Suinocultura } & 35 & 5-25 & 0,9-6,0 & 40-60\end{array}$

Reator anaeróbio de leito fixo de fluxo ascendente $\mathrm{a}^{\mathrm{a}}$

$\begin{array}{lcccc}\text { Indústria química } & 37 & 12-15 & 22-31 & 80-90 \\ \text { Indústria alimentícia } & 37 & 7,7 & 29 & 61\end{array}$

Reator anaeróbio vertical de leito fixo ${ }^{\mathrm{b}}$

$\begin{array}{lllll}\text { Indústria alimentícia } & 30 & 1,6-3,4 & 11-21 & 43-70\end{array}$

Fonte: adaptado de Metcalf \& Eddy (2003).

${ }^{\text {a }}$ Reatores utilizando anéis de Pall como meio suporte para imobilização celular.

${ }^{\mathrm{b}}$ Reator utilizando argila expandida e matrizes cúbicas de espuma de poliuretano como meio suporte para imobilização celular.

Os resultados médios de todos os parâmetros analisados durante a operação do reator anaeróbio vertical de leito fixo são apresentados na Tabela 5.3. 
Tabela 5.3 - Resultados médios dos parâmetros analisados durante a operação do reator anaeróbio vertical de leito fixo.

\begin{tabular}{|c|c|c|c|c|c|c|c|c|}
\hline \multirow{2}{*}{$\begin{array}{c}\text { TDH } \\
\text { Parâmetros }\end{array}$} & \multicolumn{2}{|c|}{11 horas $^{\mathrm{c}}$} & \multicolumn{2}{|c|}{17 horas } & \multicolumn{2}{|c|}{21 horas } & \multicolumn{2}{|c|}{24 horas } \\
\hline & Afluente & Efluente & Afluente & Efluente & Afluente & Efluente & Afluente & Efluente \\
\hline Temperatura $\left({ }^{\circ} \mathrm{C}\right)$ & $30,1 \pm 1,0$ & $28,6 \pm 0,7$ & $30,0 \pm 3,5$ & $28,7 \pm 1,2$ & $25,7 \pm 2,8$ & $30,2 \pm 0,6$ & $26,3 \pm 1,0$ & $29,3 \pm 1,1$ \\
\hline $\mathrm{AB}^{\mathrm{a}}(\mathrm{mg} \mathrm{CaCO} / \mathrm{l})$ & $66 \pm 31$ & $108 \pm 54$ & $64 \pm 36$ & $113 \pm 75$ & $72 \pm 35$ & $149 \pm 58$ & $286 \pm 168$ & $307 \pm 219$ \\
\hline DQO bruta $\left(\mathrm{mg} \mathrm{O}_{2} / \mathrm{l}\right)$ & $1255 \pm 232$ & $711 \pm 129$ & $1281 \pm 164$ & $507 \pm 111$ & $1396 \pm 153$ & $419 \pm 69$ & $1384 \pm 37$ & $585 \pm 84$ \\
\hline $\mathrm{AVT}^{\mathrm{b}}$ (mg HAc/l) & $179 \pm 73$ & $244 \pm 55$ & $150 \pm 43$ & $174 \pm 32$ & $76 \pm 49$ & $124 \pm 51$ & $112 \pm 58$ & $194 \pm 44$ \\
\hline NTK (mg N/l) & $141 \pm 27$ & $133 \pm 21$ & $136 \pm 33$ & $120 \pm 24$ & $113 \pm 22$ & $110 \pm 14$ & $128 \pm 24$ & $119 \pm 23$ \\
\hline $\mathrm{N}-\mathrm{NH}_{4}{ }^{+}(\mathrm{mg} \mathrm{N} / \mathrm{l})$ & $51 \pm 16$ & $98 \pm 21$ & $44 \pm 16$ & $97 \pm 21$ & $34 \pm 9$ & $88 \pm 14$ & $42 \pm 18$ & $93 \pm 19$ \\
\hline N-org (mg N/l) & $90 \pm 24$ & $36 \pm 12$ & $92 \pm 23$ & $23 \pm 11$ & $80 \pm 21$ & $22 \pm 7$ & $86 \pm 22$ & $26 \pm 14$ \\
\hline
\end{tabular}

${ }^{\mathrm{a}} \mathrm{AB}$ : Alcalinidade a bicarbonato

${ }^{\mathrm{b}}$ AVT: Ácidos voláteis totais

${ }^{\mathrm{c}}$ Resultados desconsiderando o período de adaptação 


\subsection{ETAPA 2 - REATOR COMBINADO ANAERÓBIO-AERÓBIO VERTICAL DE LEITO FIXO}

Devido à inoculação dos módulos aeróbios, o reator combinado anaeróbioaeróbio vertical de leito fixo teve partida rápida, atingindo eficiências acima de $80 \%$ na remoção de DQO a partir do $1^{\circ}$ dia de operação e NTK a partir do $7^{\circ}$ dia. O reator foi operado continuamente por 90 dias com temperatura controlada em $30 \pm 1^{\circ} \mathrm{C}$.

Na Figura 5.13 é apresentado o perfil de eficiência na remoção de DQO (demanda química de oxigênio) e SST (sólidos em suspensão totais), enquanto que na Figura 5.14 é apresentado o perfil de eficiência na remoção de NTK (nitrogênio total Kjeldahl) e NT (nitrogênio total), ao longo do tempo de operação do reator combinado anaeróbio-aeróbio vertical de leito fixo.

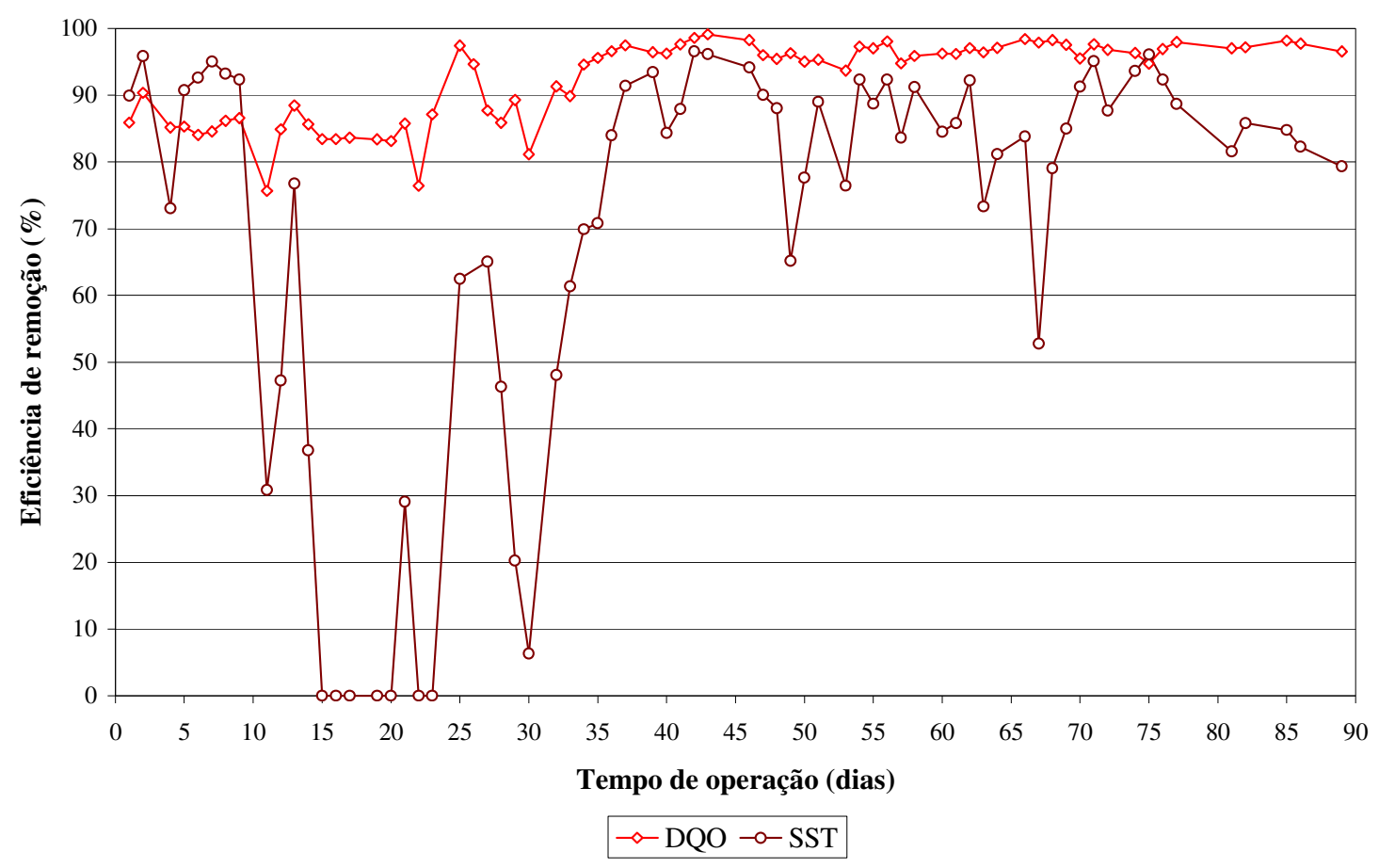

Figura 5.13 - Eficiência na remoção de DQO e SST ao longo do tempo de operação do reator combinado anaeróbio-aeróbio vertical de leito fixo. 


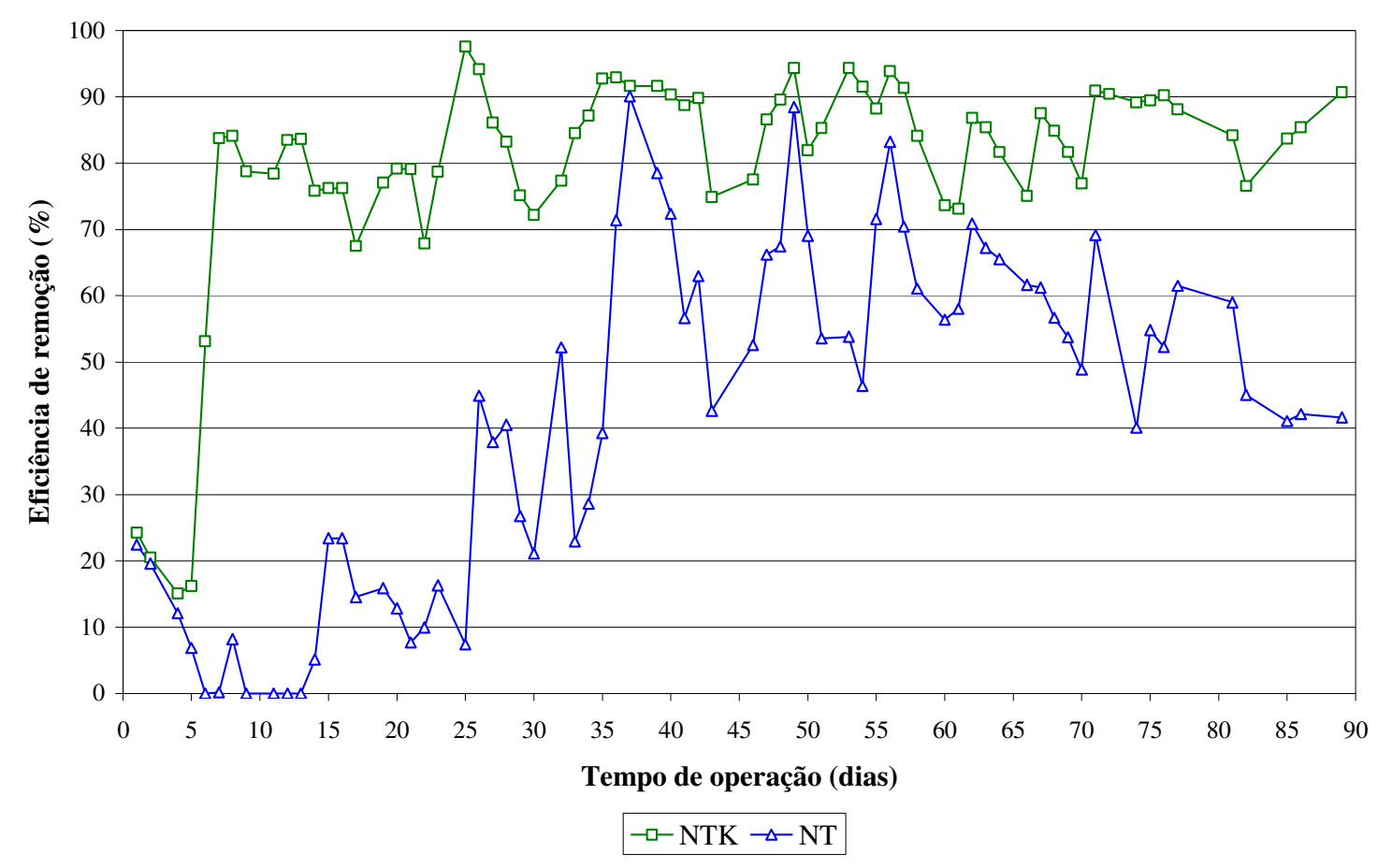

Figura 5.14 - Eficiência na remoção de NTK e NT ao longo do tempo de operação do reator combinado anaeróbio-aeróbio vertical de leito fixo.

Entre os dias 11 e 30, como pode ser notado na Figura 5.15, o efluente tratado apresentou-se com grande quantidade de sólidos em suspensão, $134 \pm 46$ mg SST/1 e 128 + 46 mg SSV/l. Embora a água residuária da Ajinomoto também apresentasse altas concentração de sólidos suspensos, com valores médios de $213 \pm 123 \mathrm{mg} \mathrm{SST/1}$ e $202 \pm$ $118 \mathrm{mg} \mathrm{SSV} / 1$, a presença elevada deste material no efluente tratado entre os dias $11 \mathrm{e}$ 30 foi atribuída principalmente ao desprendimento da biomassa aeróbia não aderida aos suportes após a inoculação, provocando também a elevação das concentrações de DQO efluente. As eficiências médias na remoção de DQO e SST apresentadas nesse período foram de $86 \pm 5 \%$ e $25 \pm 27 \%$, respectivamente (Figura 5.13).

Com o passar do tempo, a biomassa suspensa foi lavada do sistema, decrescendo significativamente a sua concentração no efluente a partir do $31^{\circ}$ dia. A partir de então, a concentração de sólidos em suspensão no efluente tratado se manteve baixa, com valores médios de $27 \pm 15 \mathrm{mg} \mathrm{SST} / 1$ e $24 \pm 15 \mathrm{mg}$ SSV/l. Conseqüentemente, as eficiências de remoção de DQO e SST aumentaram (Figura 5.13), obtendo valores médios de $96 \pm 2 \%$ e $84 \pm 11 \%$, respectivamente. 


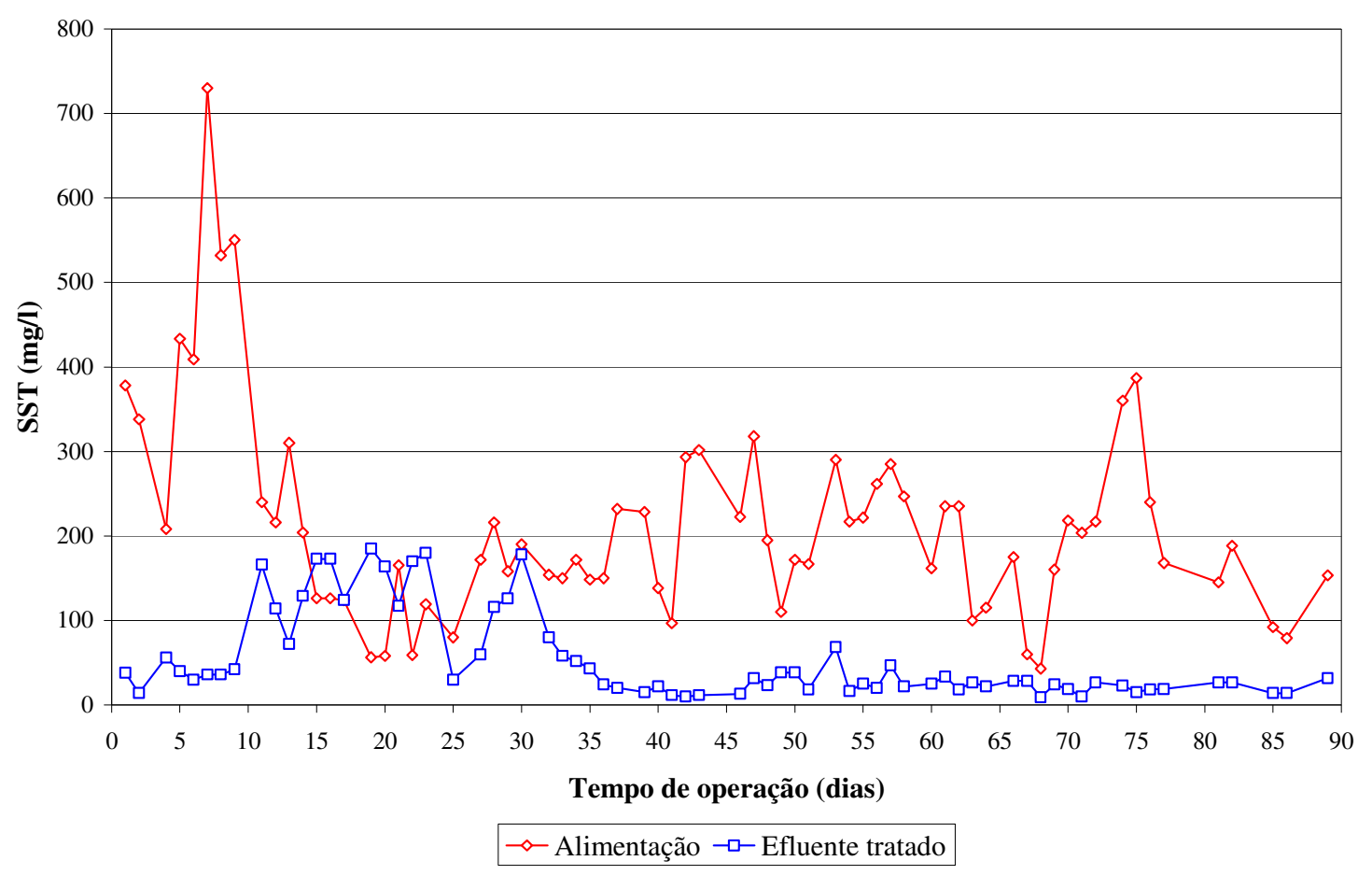

Figura 5.15 - Sólidos suspensos totais (SST) na alimentação e no efluente tratado do reator combinado anaeróbio-aeróbio vertical de leito fixo ao longo do tempo de operação.

O reator combinado anaeróbio-aeróbio operou com DQO afluente média de $1382 \pm 105 \mathrm{mg} \mathrm{O}$ / $/$, sendo que a partir do $31^{\circ}$ dia de operação, o efluente tratado apresentou valores próximos de DQO bruta e filtrada, respectivamente, $50 \pm 25 \mathrm{mg} / \mathrm{l} \mathrm{e}$ $37 \pm 17 \mathrm{mg} / \mathrm{l}$, evidenciando a boa retenção de sólidos no reator. Na Figura 5.16 é apresentada a variação da DQO afluente e efluente ao longo do tempo de operação do reator.

Como pode ser visto na Figura 5.17, a concentração afluente de ácidos voláteis totais (AVT) variou bastante ao longo da operação do reator, tendo valor médio de 232 $\pm 96 \mathrm{mg} \mathrm{HAc/l}$. Contudo, a concentração de AVT efluente se manteve praticamente constante e muito próxima da DQO filtrada efluente, com valor médio de $37 \pm 10 \mathrm{mg}$ $\mathrm{HAc} / \mathrm{l}$. 


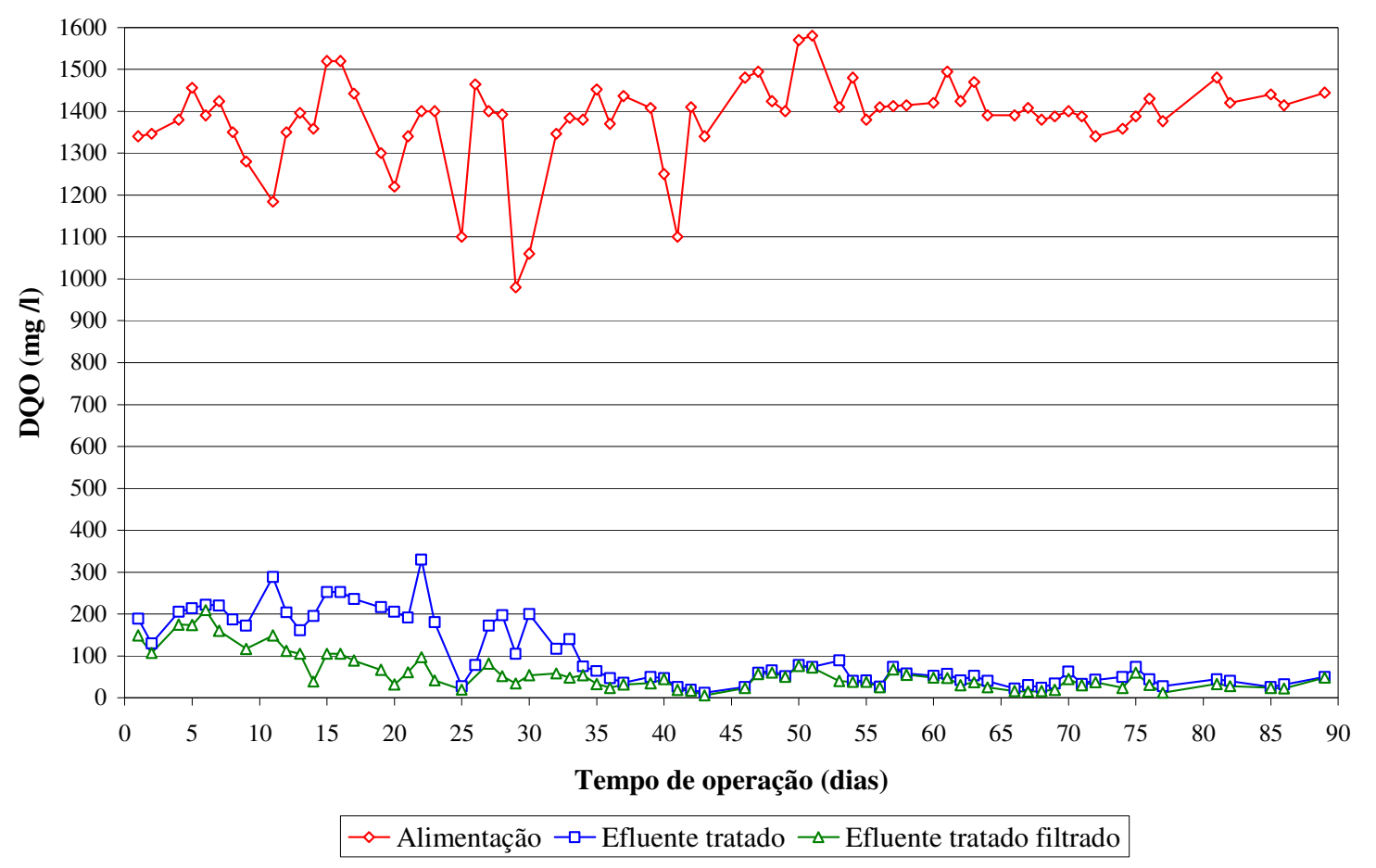

Figura 5.16 - DQO na alimentação e no efluente tratado do reator combinado anaeróbio-aeróbio vertical de leito fixo ao longo do tempo de operação.

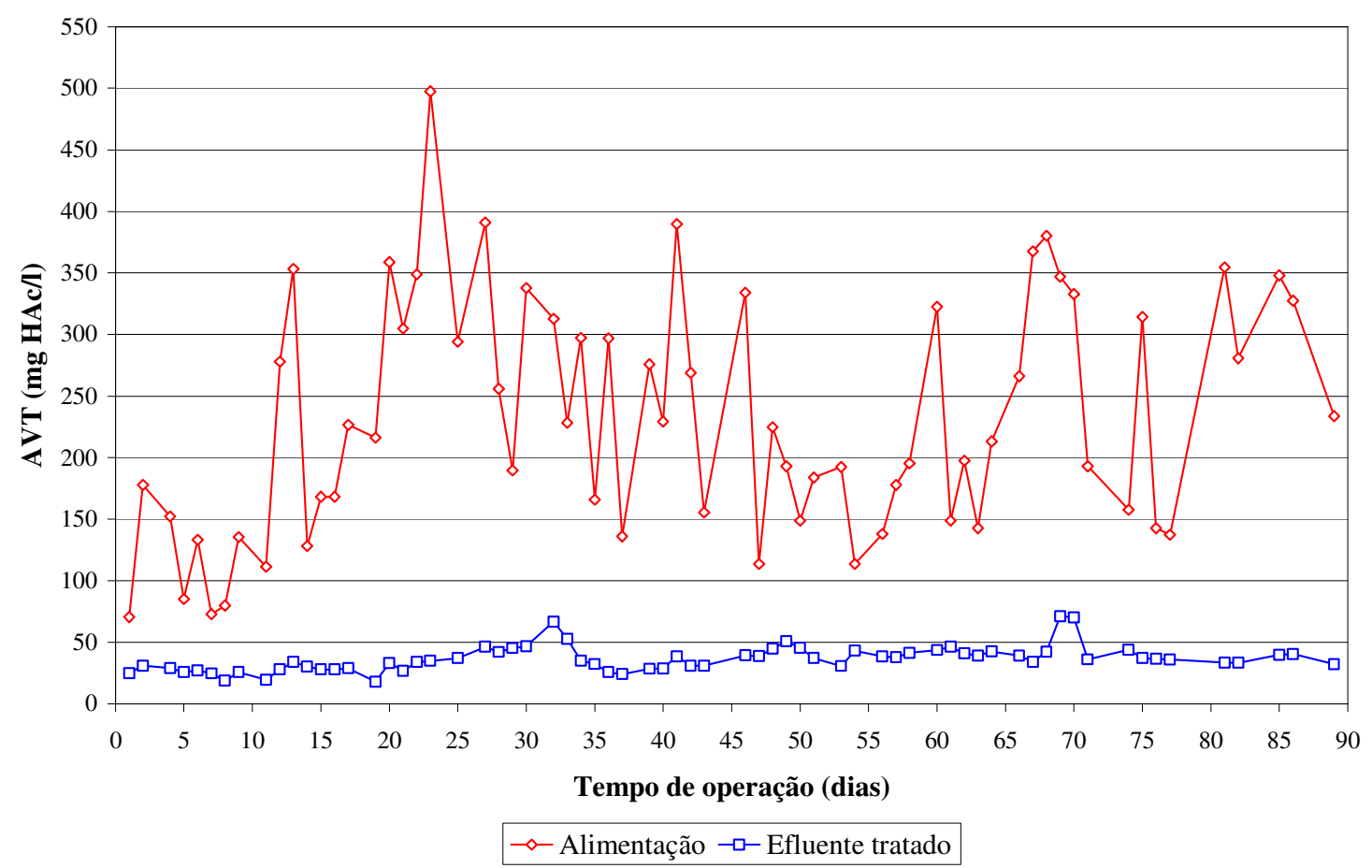

Figura 5.17 - Ácidos voláteis totais (AVT) na alimentação e no efluente tratado do reator combinado anaeróbio-aeróbio vertical de leito fixo ao longo do tempo de operação. 
A atividade nitrificante foi evidenciada a partir do $6^{\circ}$ dia de operação com a queda do NTK efluente, como pode ser visto na Figura 5.18. Do $7^{\circ}$ dia em diante a nitrificação apresentou-se estável com eficiência média de $84 \pm 11 \%$ (Figura 5.13) e com NTK efluente de $24 \pm 11 \mathrm{mg}$ N/l. Devido à ausência de N-nitrito e N-nitrato na água residuária da Ajinomoto, a concentração de NT na alimentação do sistema igualou-se a concentração de NTK, com valor médio de $146 \pm 29 \mathrm{mg} \mathrm{N} / 1$, sendo 56\% do nitrogênio na forma orgânica e $44 \%$ na forma amoniacal.

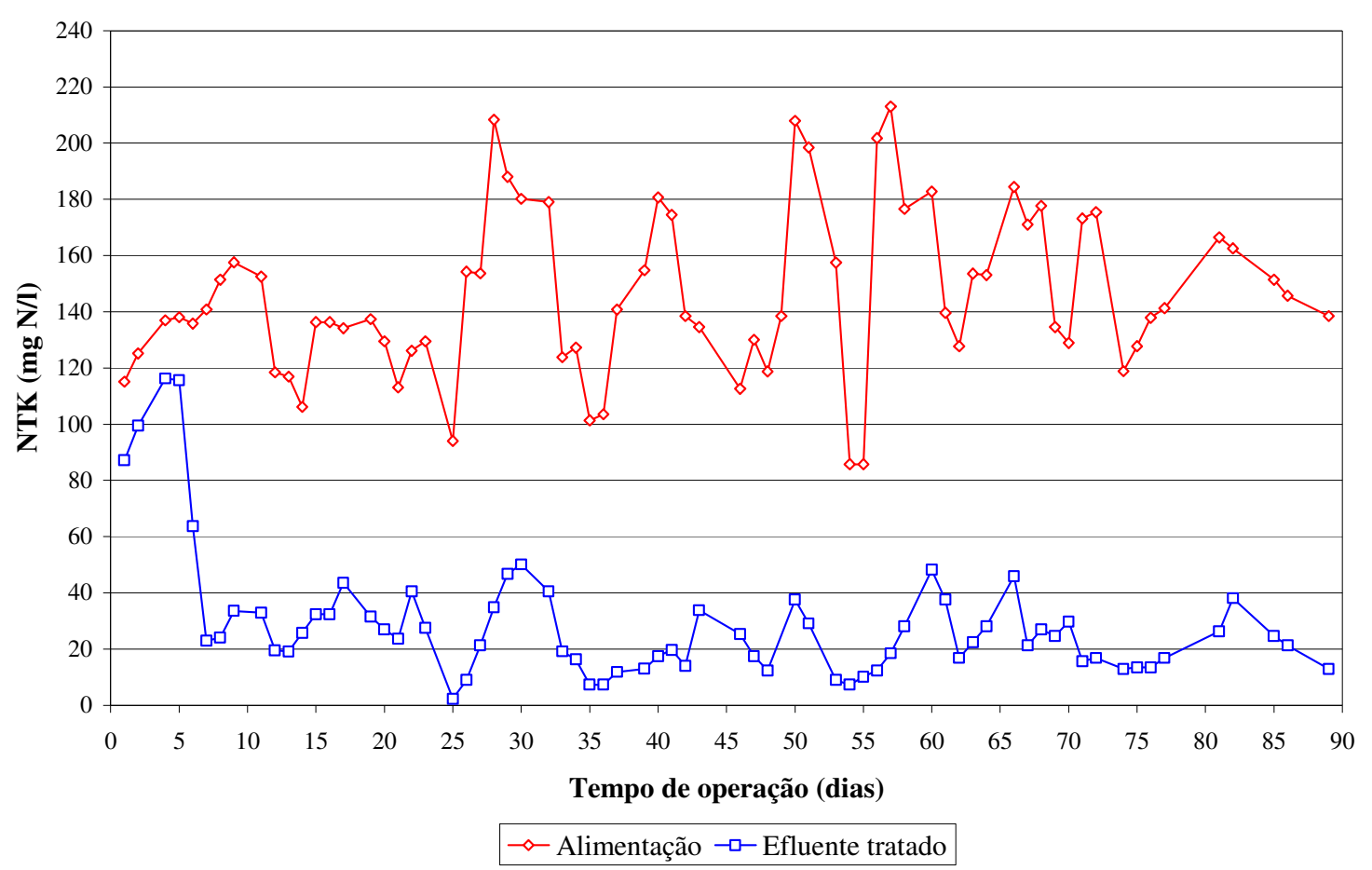

Figura 5.18 - NTK na alimentação e no efluente tratado do reator combinado anaeróbio-aeróbio vertical de leito fixo ao longo do tempo de operação.

Outro indicador do início da nitrificação foi o significativo aumento no consumo de alcalinidade a bicarbonato observado a partir do $6^{\circ}$ dia de operação. Deste ponto em diante, os valores de alcalinidade a bicarbonato no efluente tratado mantiveram-se sempre inferiores aos valores observados na alimentação, com valores médios de $461 \pm$ $82 \mathrm{mg} \mathrm{CaCO}_{3} / \mathrm{l}$ e $673 \pm 88 \mathrm{mg} \mathrm{CaCO}_{3} / \mathrm{l}$, respectivamente. $\mathrm{Na}$ Figura 5.19 são apresentados os valores de alcalinidade a bicarbonato na alimentação e no efluente tratado ao longo do tempo de operação do reator. 
Na maioria dos dias de operação do reator combinado anaeróbio-aeróbio vertical de leito fixo, o valor de $\mathrm{pH}$ do efluente tratado manteve-se ligeiramente superior ao valor de $\mathrm{pH}$ da alimentação, com valores médios de 8,3 \pm 0,3 e 8,1 \pm 0,3, respectivamente. Na Figura 5.20 são apresentados os valores de pH na alimentação e no efluente tratado ao longo do tempo de operação do reator.

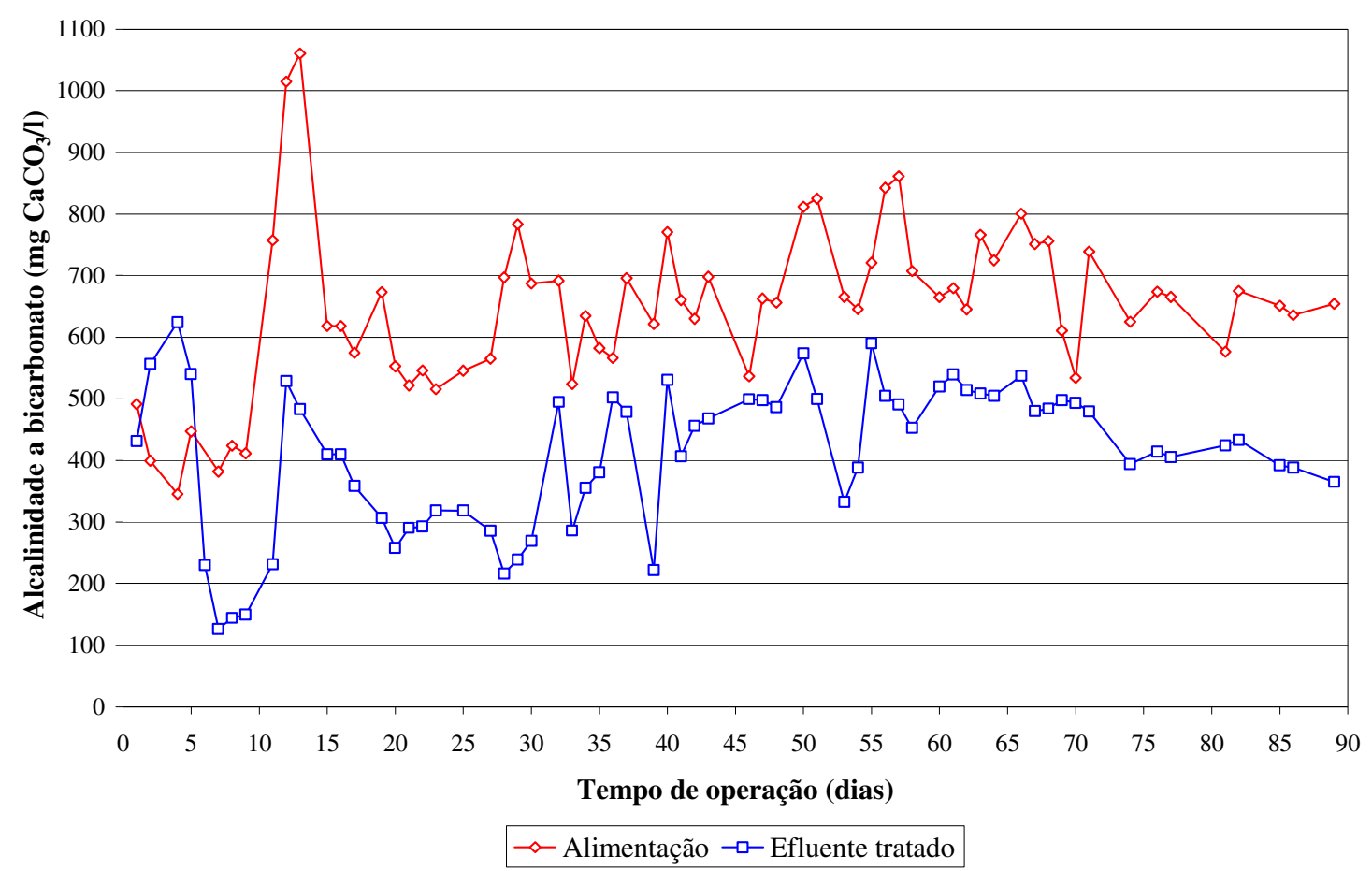

Figura 5.19 - Alcalinidade a bicarbonato na alimentação e no efluente tratado do reator combinado anaeróbio-aeróbio vertical de leito fixo ao longo do tempo de operação. 


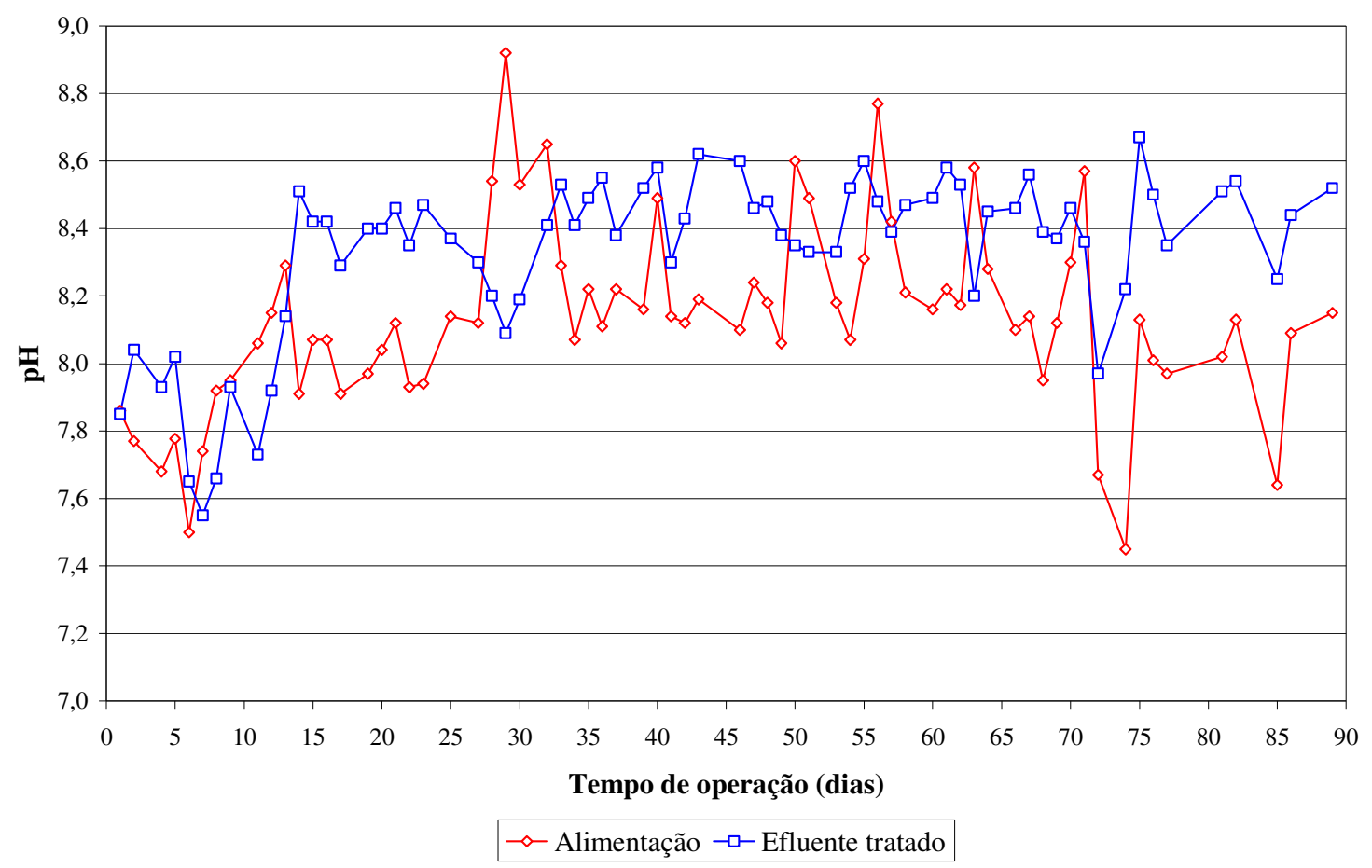

Figura 5.20 - pH na alimentação e no efluente tratado do reator combinado anaeróbioaeróbio vertical de leito fixo ao longo do tempo de operação.

No início da atividade nitrificante, entre os dias 6 e 12, a nitratação ainda não estava completamente estabelecida, ocorrendo acúmulo de $\mathrm{N}$-nitrito no efluente tratado com concentração média de $50 \pm 8 \mathrm{mg} \mathrm{N}-\mathrm{NO}_{2}{ }^{-} / 1$. Após este período praticamente todo o nitrito formado foi oxidado a nitrato, como pode ser visto no gráfico da Figura 5.21. 


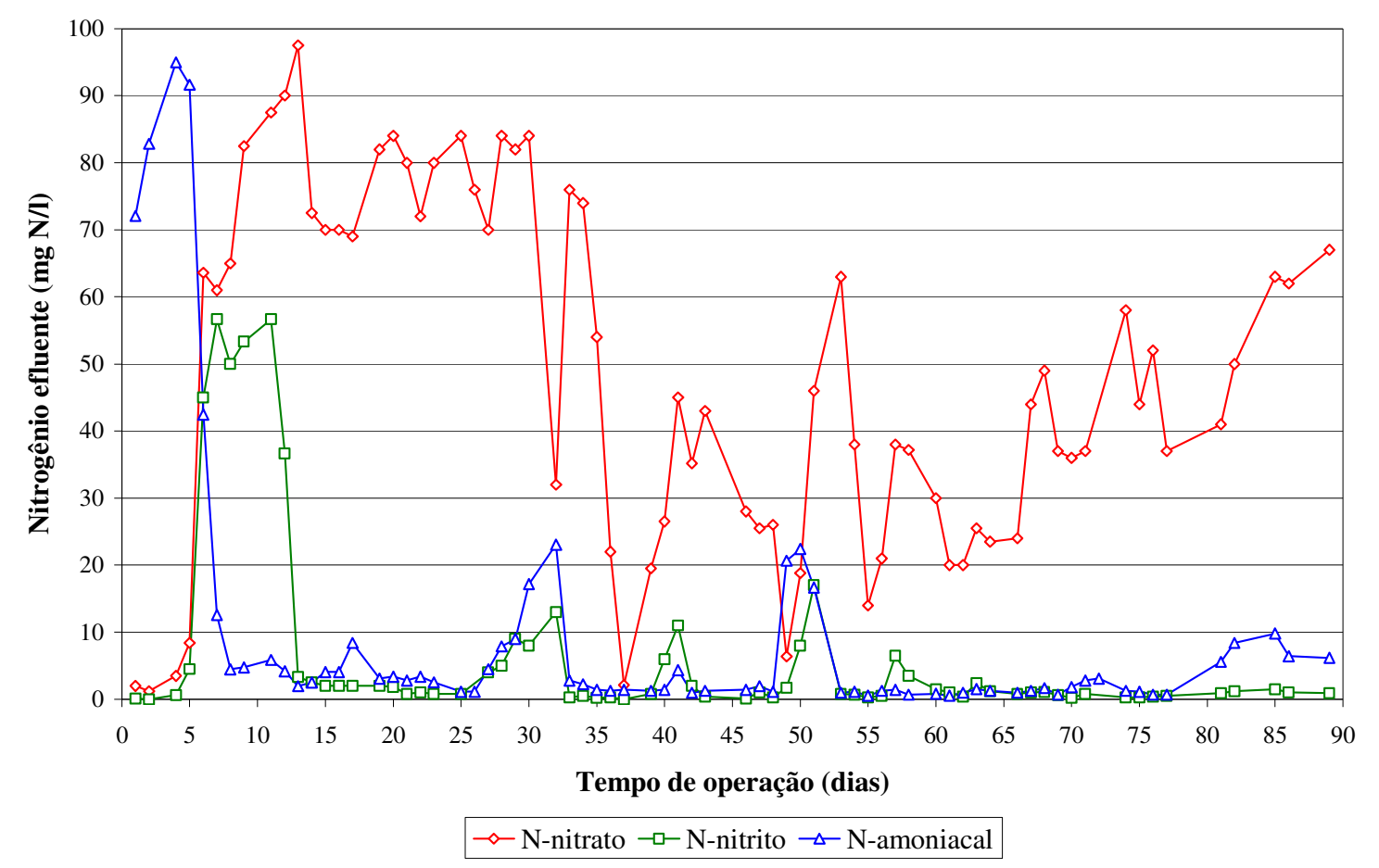

Figura 5.21 - Concentrações efluentes de N-amoniacal, N-nitrito e N-nitrato do reator combinado anaeróbio-aeróbio vertical de leito fixo ao longo do tempo de operação.

Foram observadas elevadas concentrações de $\mathrm{N}$-amoniacal e $\mathrm{N}$-nitrito no efluente tratado nos períodos entre os dias 27 a 32, 49 a 51 e 81 a 89 (Figura 5.21),

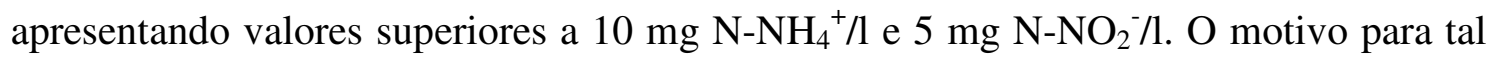
elevação foi relacionado com o aumento repentino da concentração de NTK na alimentação do sistema (Figura 5.17), passando de cerca de $120 \mathrm{mg}$ NTK/l para valores acima de $160 \mathrm{mg}$ NTK/l de um dia para outro, representando um aumento de mais de $25 \%$ na carga de nitrogênio afluente. Apesar disto, o sistema reagiu bem a esses choques de carga e salvo durante os períodos citados, as concentrações de $\mathrm{N}$-amoniacal e N-nitrito efluentes mantiveram-se baixas, com valores médios de $2 \pm 2 \mathrm{mg} \mathrm{N}-\mathrm{NH}_{4}{ }^{+} / \mathrm{l} \mathrm{e}$ $1 \pm 2 \mathrm{mg} \mathrm{N}-\mathrm{NO}_{2}{ }^{-} / 1$, respectivamente.

A partir do $35^{\circ}$ dia de operação, as concentrações de $\mathrm{N}$-nitrato no efluente

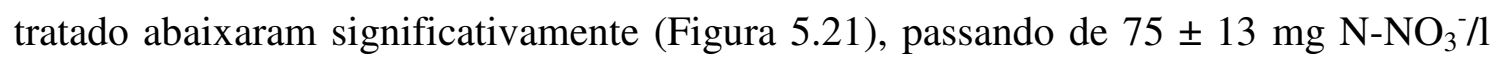
para $35 \pm 16 \mathrm{mg} \mathrm{N}-\mathrm{NO}_{3}{ }^{-} / 1$, fazendo com que o nitrogênio total (NT) efluente apresentasse valor muito inferior ao NT afluente, evidenciando a atividade desnitrificante no reator aeróbio. Até o $35^{\circ}$ dia, a eficiência média de remoção de NT era de $17 \pm 15 \%$ (Figura 5.14) com concentração média de NT efluente de $116 \pm 28 \mathrm{mg} \mathrm{N} / \mathrm{l}$. 
Após esse dia, a eficiência na remoção de NT passou para $61 \pm 13 \%$ com concentração média de NT efluente de $58 \pm 20 \mathrm{mg}$ N/l. Na Figura 5.22 são apresentados os valores de nitrogênio total na alimentação e no efluente tratado do reator combinado anaeróbioaeróbio ao longo do tempo de operação.

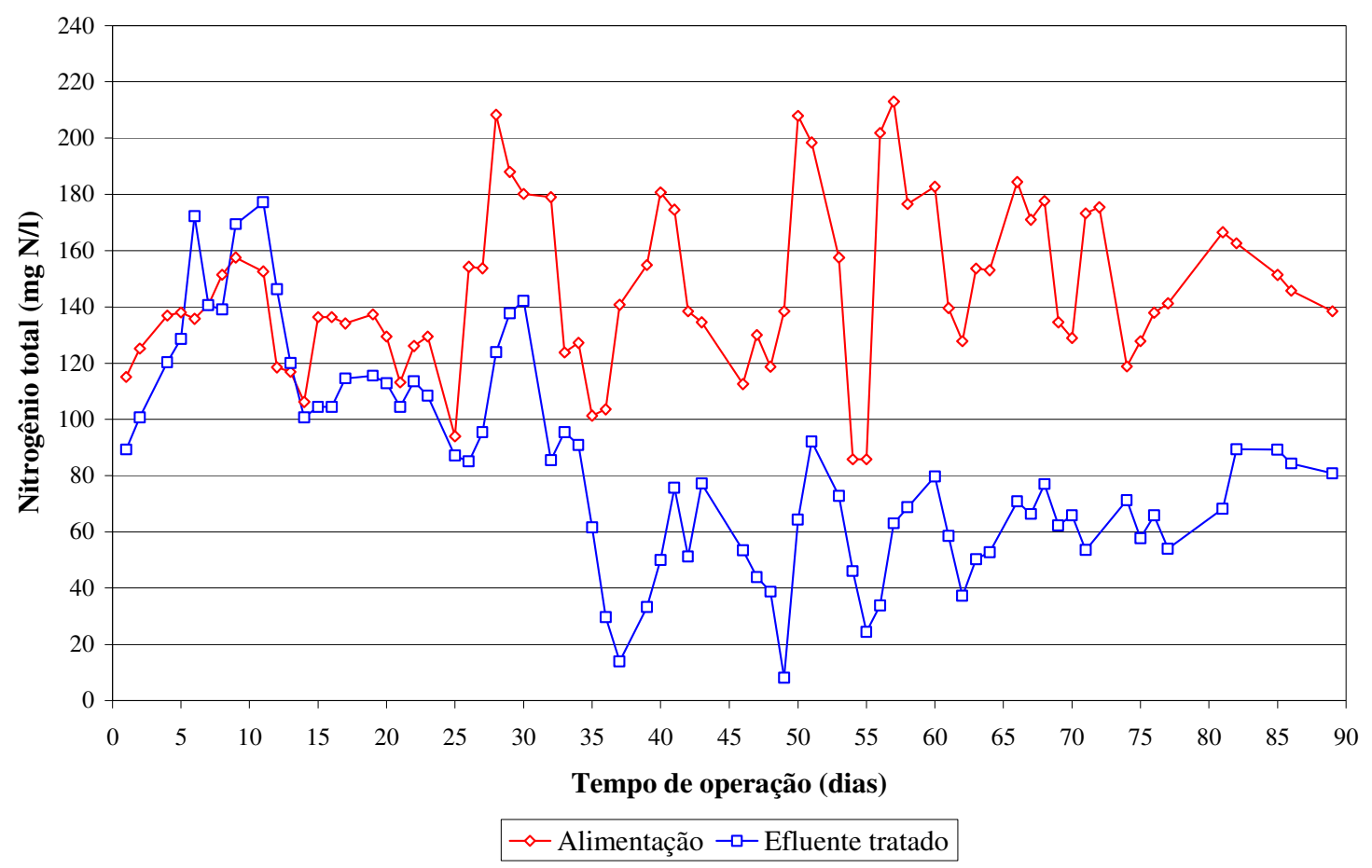

Figura 5.22 - Nitrogênio total (NT) na alimentação e no efluente tratado do reator combinado anaeróbio-aeróbio vertical de leito fixo ao longo do tempo de operação.

A ocorrência de altos níveis de desnitrificação durante a operação do reator combinado anaeróbio-aeróbio vertical de leito fixo foi inesperada, pois as concentrações de oxigênio dissolvido nos módulos aeróbios eram altas, na faixa de 3 a $6 \mathrm{mg} \mathrm{O} / \mathrm{l}$, como pode ser visto no gráfico da Figura 5.23. Entretanto, segundo Metcalf \& Eddy (2003), a concentração de oxigênio no interior do biofilme poderia ser menor que no meio líquido, criando condições favoráveis para a atividade desnitrificante nestes locais.

Entre os possíveis processos de remoção de nitrogênio que poderiam estar ocorrendo no reator estão: 1) o processo CANON (completely autotrophic nitrogen removal over nitrite) em que estão combinados os processos de nitrificação parcial e oxidação anaeróbia de amônio (ANAMMOX); 2) o processo OLAND (oxygen-limited nitrification and denitrification) em que o nitrogênio seria removido através de desnitrificação autotrófica pelas bactérias do gênero Nitrossomonas; e 3) processo 
convencional de desnitrificação heterotrófica utilizando-se como doadores de elétrons a matéria orgânica remanescente ou produtos gerados no reator anaeróbio, tais como, metano, álcoois, ácidos orgânicos e compostos reduzidos de enxofre.

O fenômeno de nitrificação e desnitrificação simultâneas observado nos módulos aeróbios do reator combinado anaeróbio-aeróbio vertical de leito fixo mostrou que o nitrogênio afluente pode ser removido em uma única etapa de tratamento, não necessitando de sistemas de pós-tratamento ou recirculação do efluente tratado em reatores desnitrificantes (anóxicos ou anaeróbios). Nesta condição, seria possível projetar reatores mais compactos e com um menor custo de implantação e operação. Contudo, a dificuldade de controle da atividade desnitrificante em ambiente aeróbio onde é processada a nitrificação ainda é o principal limitante para a implantação deste processo.

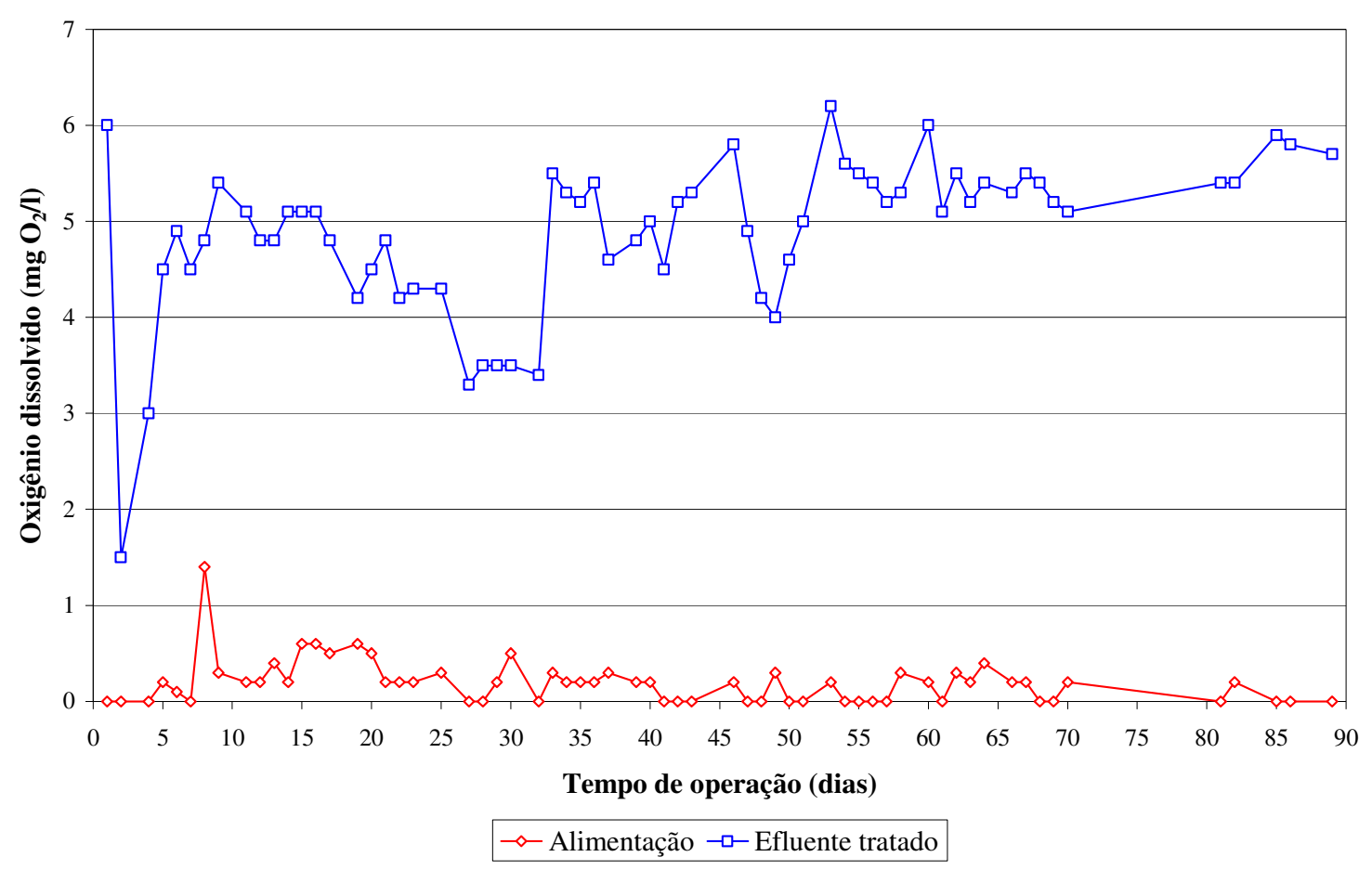

Figura 5.23 - Oxigênio dissolvido (OD) na alimentação e no efluente tratado do reator combinado anaeróbio-aeróbio vertical de leito fixo ao longo do tempo de operação.

A carga orgânica volumétrica (COV) média aplicada ao reator combinado anaeróbio-aeróbio vertical de leito fixo foi de 0,94 $\pm 0,07 \mathrm{~kg}$ DQO. $\mathrm{m}^{-3} \cdot \mathrm{d}^{-1}$, considerando volume útil total do reator igual a 28,3 1 (17 1 da zona anaeróbia e 11,3 1 da zona aeróbia). Se analisado separadamente, na zona anaeróbia a COV média aplicada foi de 
1,56 $\pm 0,12 \mathrm{~kg}$ DQO. $\mathrm{m}^{-3} \cdot \mathrm{d}^{-1}$ enquanto que no reator aeróbio, considerando-se que a eficiência média do reator anaeróbio na remoção de DQO era de $70 \%$ conforme resultados da primeira etapa experimental, a COV média aplicada foi de 0,70 $\pm 0,05 \mathrm{~kg}$ DQO. $\mathrm{m}^{-3} \cdot \mathrm{d}^{-1}$.

Como a remoção de nitrogênio na zona anaeróbia do reator era desprezível, a carga volumétrica de nitrogênio aplicada à zona aeróbia, baseada no seu volume útil (11,3 litros), foi calculada levando-se em consideração a concentração de NTK da alimentação do sistema, obtendo valor médio de $0,25 \pm 0,05 \mathrm{~kg} \mathrm{~N} \cdot \mathrm{m}^{-3} \cdot \mathrm{d}^{-1}$.

Na Figura 5.24 são apresentados os perfis de carga orgânica volumétrica (COV) aplicada ao reator combinado anaeróbio-aeróbio vertical de leito fixo e de carga volumétrica de nitrogênio $(\mathrm{CVN})$ aplicada à zona aeróbia do reator ao longo do tempo de operação.

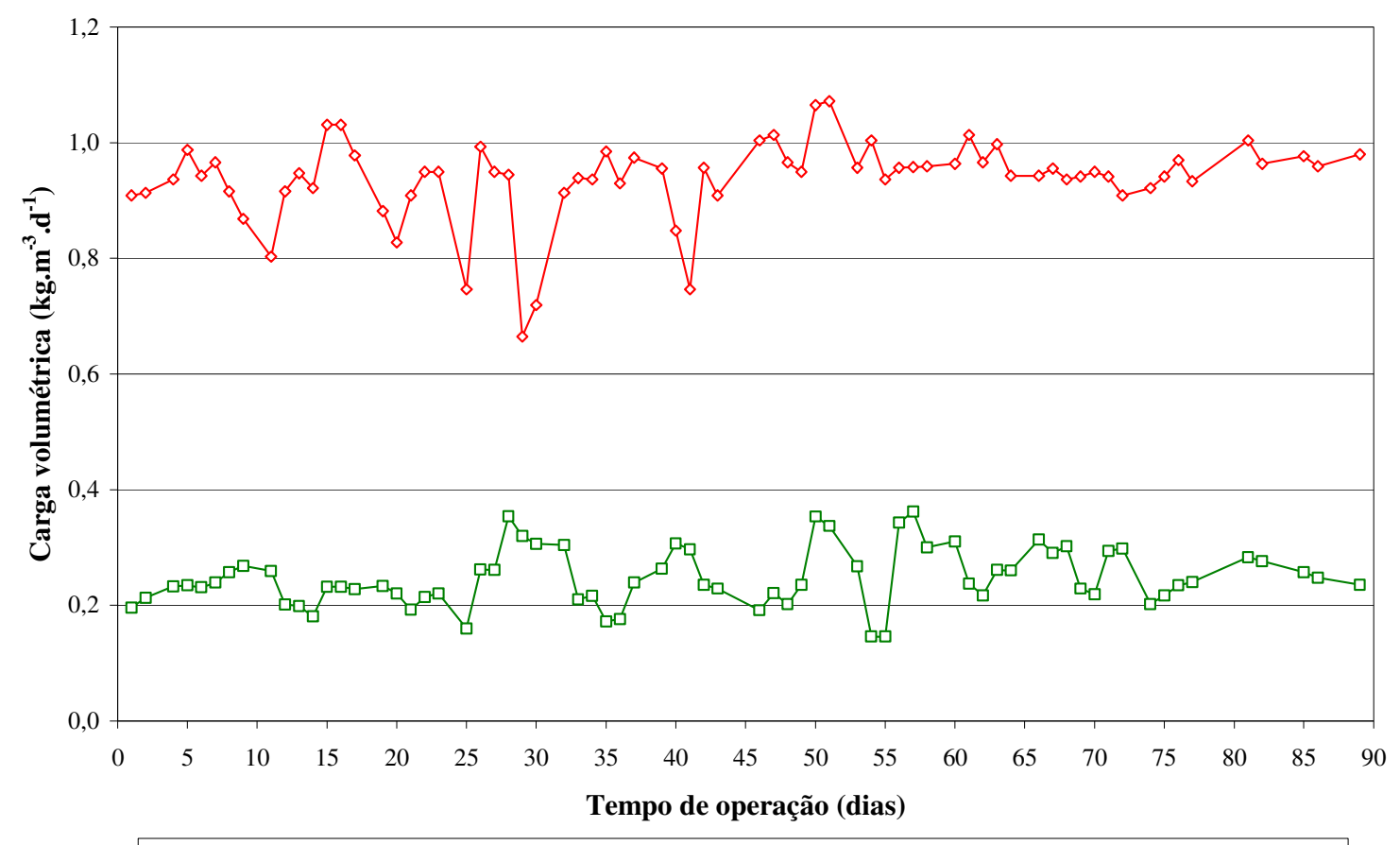

$\neg-$ COV aplicada ao reator combinado anaeróbio-aeróbio $-\square-\mathrm{CVN}$ aplicada à zona aeróbia do reator

Figura 5.24 - Carga orgânica volumétrica (COV) aplicada ao reator combinado anaeróbio-aeróbio vertical de leito fixo e carga volumétrica de nitrogênio (CVN) aplicada à zona aeróbia do reator ao longo do tempo de operação.

Comparado com sistemas convencionais de tratamento por lodos ativados, o sistema combinado anaeróbio-aeróbio vertical de leito fixo apresentou desempenho satisfatório no tratamento da água residuária da Ajinomoto, com desempenhos médios 
de $96 \pm 2 \%$ na remoção de DQO e $84 \pm 11 \%$ na nitrificação.

Na Tabela 5.4 são apresentados parâmetros operacionais típicos de sistemas de tratamento por lodos ativados visando a remoção de matéria orgânica e nitrificação, citados por Metcalf \& Eddy (2003), em comparação com os parâmetros obtidos para o reator combinado anaeróbio-aeróbio vertical de leito fixo.

Tabela 5.4 - Comparação entre os parâmetros operacionais de sistemas de tratamento por lodos ativados e reator combinado anaeróbio-aeróbio vertical de leito fixo.

Tipo de sistema de tratamento

\section{$\mathrm{COV}^{\mathrm{a}} \quad$ TDH}

$\left(k g\right.$ DQO.m $\left.{ }^{-3} \cdot d^{-1}\right) \quad$ (h)

\begin{tabular}{lcc}
\hline Lodos ativados convencional & $0,6-3,2$ & $3-5$ \\
Lodos ativados por aeração prolongada & $0,2-0,6$ & $20-30$ \\
SBR (sequencing batch reactor) & $0,2-0,6$ & $15-40$ \\
Reator combinado anaeróbio-aeróbio vertical & $0,9^{\mathrm{b}}$ & $35^{\mathrm{b}}$ \\
de leito fixo & &
\end{tabular}

Fonte: adaptado de Metcalf \& Eddy (2003).

${ }^{a}$ Carga orgânica considerando relação DQO/DBO igual a 2.

${ }^{\mathrm{b}}$ Parâmetros baseados no volume útil do reator (28,3 litros).

Os resultados médios de todos os parâmetros analisados durante a operação do reator combinado anaeróbio-aeróbio vertical de leito fixo são apresentados na Tabela 5.5. Nesta tabela os resultados foram divididos em dois períodos operacionais. O primeiro, entre os dias 1 e 30, representa o período de adaptação do sistema, no qual ocorreu grande escape de sólidos em suspensão no efluente tratado, e o segundo, entre os dias 31 e 90, representa o período de operação estável do reator. 
Tabela 5.5 - Resultados médios dos parâmetros analisados durante a operação do reator combinado anaeróbio-aeróbio vertical de leito fixo.

\begin{tabular}{|c|c|c|c|c|}
\hline \multirow{2}{*}{$\begin{array}{l}\text { Período operacional } \\
\text { Parâmetros }\end{array}$} & \multicolumn{2}{|c|}{$1^{\circ}$ ao $30^{\circ}$ dia } & \multicolumn{2}{|c|}{$31^{\circ}$ ao $90^{\circ}$ dia } \\
\hline & Afluente & Efluente & Afluente & Efluente \\
\hline Temperatura $\left({ }^{\circ} \mathrm{C}\right)$ & $25,5 \pm 1,4$ & $29,9 \pm 1,1$ & $25,5 \pm 1,2$ & $29,3 \pm 0,8$ \\
\hline $\mathrm{pH}$ & $8,0 \pm 0,3$ & $8,1 \pm 0,3$ & $8,2 \pm 0,2$ & $8,4 \pm 0,1$ \\
\hline $\mathrm{OD}^{\mathrm{a}}\left(\mathrm{mg} \mathrm{O}_{2} / \mathrm{l}\right)$ & $0,3 \pm 0,3$ & $4,4 \pm, 9$ & $0,1 \pm 0,1$ & $5,2 \pm 0,5$ \\
\hline $\mathrm{AB}^{\mathrm{b}}(\mathrm{mg} \mathrm{CaCO} / \mathrm{l})$ & $593 \pm 184$ & $334 \pm 137$ & $679 \pm 82$ & $455 \pm 76$ \\
\hline DQO bruta $\left(\mathrm{mg} \mathrm{O}_{2} / \mathrm{l}\right)$ & $1338 \pm 133$ & $193 \pm 61$ & $1408 \pm 75$ & $50 \pm 25$ \\
\hline DQO filtrada $\left(\mathrm{mg} \mathrm{O}_{2} / \mathrm{l}\right)$ & $958 \pm 243$ & $97 \pm 52$ & $1100 \pm 109$ & $37 \pm 17$ \\
\hline $\mathrm{AVT}^{\mathrm{c}}$ (mg HAc/l) & $221 \pm 116$ & $31 \pm 8$ & $238 \pm 83$ & $40 \pm 10$ \\
\hline NTK (mg N/l) & $139 \pm 25$ & $42 \pm 30$ & $149 \pm 31$ & $21 \pm 11$ \\
\hline $\mathrm{N}-\mathrm{NH}_{4}{ }^{+}(\mathrm{mg} \mathrm{N} / \mathrm{l})$ & $64 \pm 28$ & $19 \pm 30$ & $63 \pm 25$ & $4 \pm 6$ \\
\hline N-org (mg N/l) & $75 \pm 26$ & $23 \pm 9$ & $86 \pm 28$ & $18 \pm 10$ \\
\hline $\mathrm{N}-\mathrm{NO}_{2}^{-}(\mathrm{mg} \mathrm{N} / \mathrm{l})$ & - & $14 \pm 21$ & - & $2 \pm 4$ \\
\hline $\mathrm{N}-\mathrm{NO}_{3}{ }^{-}(\mathrm{mg} \mathrm{N} / \mathrm{l})$ & - & $66 \pm 28$ & - & $37 \pm 17$ \\
\hline $\mathrm{ST}(\mathrm{mg} / \mathrm{l})$ & $1600 \pm 828$ & $1241 \pm 452$ & $1436 \pm 117$ & $1031 \pm 277$ \\
\hline $\mathrm{SST}(\mathrm{mg} / \mathrm{l})$ & $248 \pm 173$ & $103 \pm 60$ & $193 \pm 77$ & $27 \pm 15$ \\
\hline $\mathrm{SSV}(\mathrm{mg} / \mathrm{l})$ & $236 \pm 166$ & $96 \pm 60$ & $183 \pm 75$ & $24 \pm 15$ \\
\hline
\end{tabular}

${ }^{\mathrm{a} O D}$ : Oxigênio dissolvido

${ }^{\mathrm{b}} \mathrm{AB}$ : Alcalinidade a bicarbonato

${ }^{\mathrm{c}}$ AVT: Ácidos voláteis totais 


\subsection{ETAPA 3 - REATOR ANAERÓBIO VERTICAL DE LEITO FIXO EM SÉRIE COM REATOR AERÓBIO VERTICAL DE LEITO FIXO}

Com o objetivo de observar os fenômenos de remoção de matéria orgânica, nitrificação e desnitrificação ocorridos em cada zona do reator, os módulos anaeróbios e aeróbios foram separados em dois reatores distintos operados em série. O reator anaeróbio manteve a mesma condição ambiental da etapa 2 , tendo uma câmara de aeração acoplada em seu topo. Para o reator aeróbio, as condições ambientais também não foram modificadas, sendo apenas separado do reator anaeróbio e acoplado em sua base uma câmara de aeração.

Visando compreender os fenômenos de nitrificação e desnitrificação, separadamente para as zonas anaeróbia e aeróbia do reator vertical de leito fixo, os módulos anaeróbios e aeróbios foram divididos em dois reatores distintos operados em série.

Após a separação das zonas anaeróbia e aeróbia, o sistema com reatores em série foi operado por 20 dias com temperatura controlada em $30 \pm 1^{\circ} \mathrm{C}$. A partir do $2^{\circ}$ dia de operação o sistema atingiu estabilidade, com eficiências médias na remoção de DQO, SST, NTK e NT, a partir deste dia, iguais a $99 \pm 1 \%, 94 \pm 3 \%, 94 \pm 3 \%$ e $17 \pm 10 \%$, respectivamente.

Na Figura 5.25 são apresentados os valores de eficiência na remoção de DQO e SST, enquanto que na Figura 5.26 são apresentados os valores de eficiência na remoção de NTK e NT, ao longo do tempo de operação do sistema com reatores anaeróbio e aeróbio verticais de leito fixo em série. 


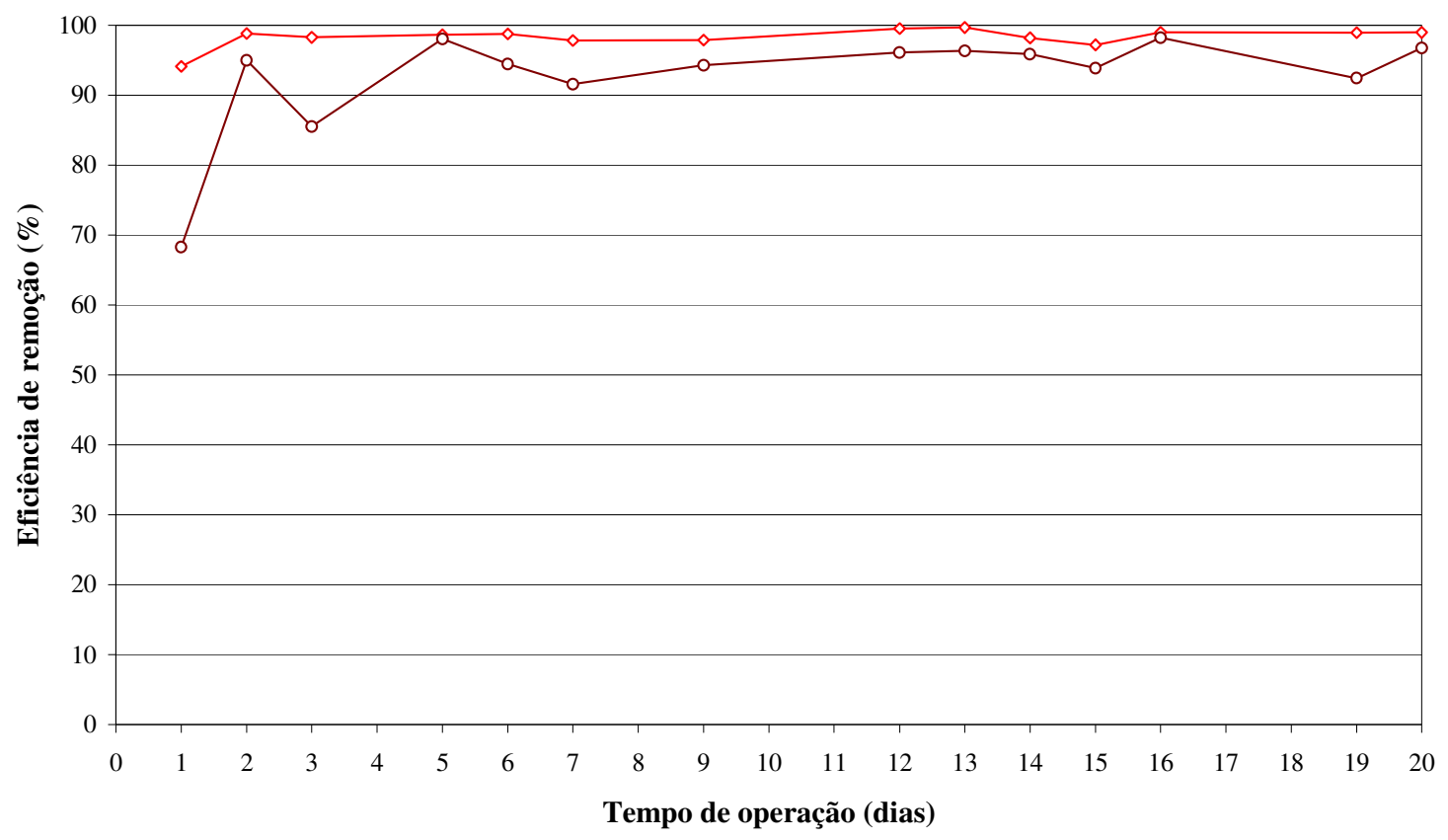

$$
\rightarrow-\text { DQO } \rightarrow \text { SST }
$$

Figura 5.25 - Eficiência na remoção de DQO e SST ao longo do tempo de operação do sistema com reatores anaeróbio com aeração no topo e aeróbio verticais de leito fixo em série.

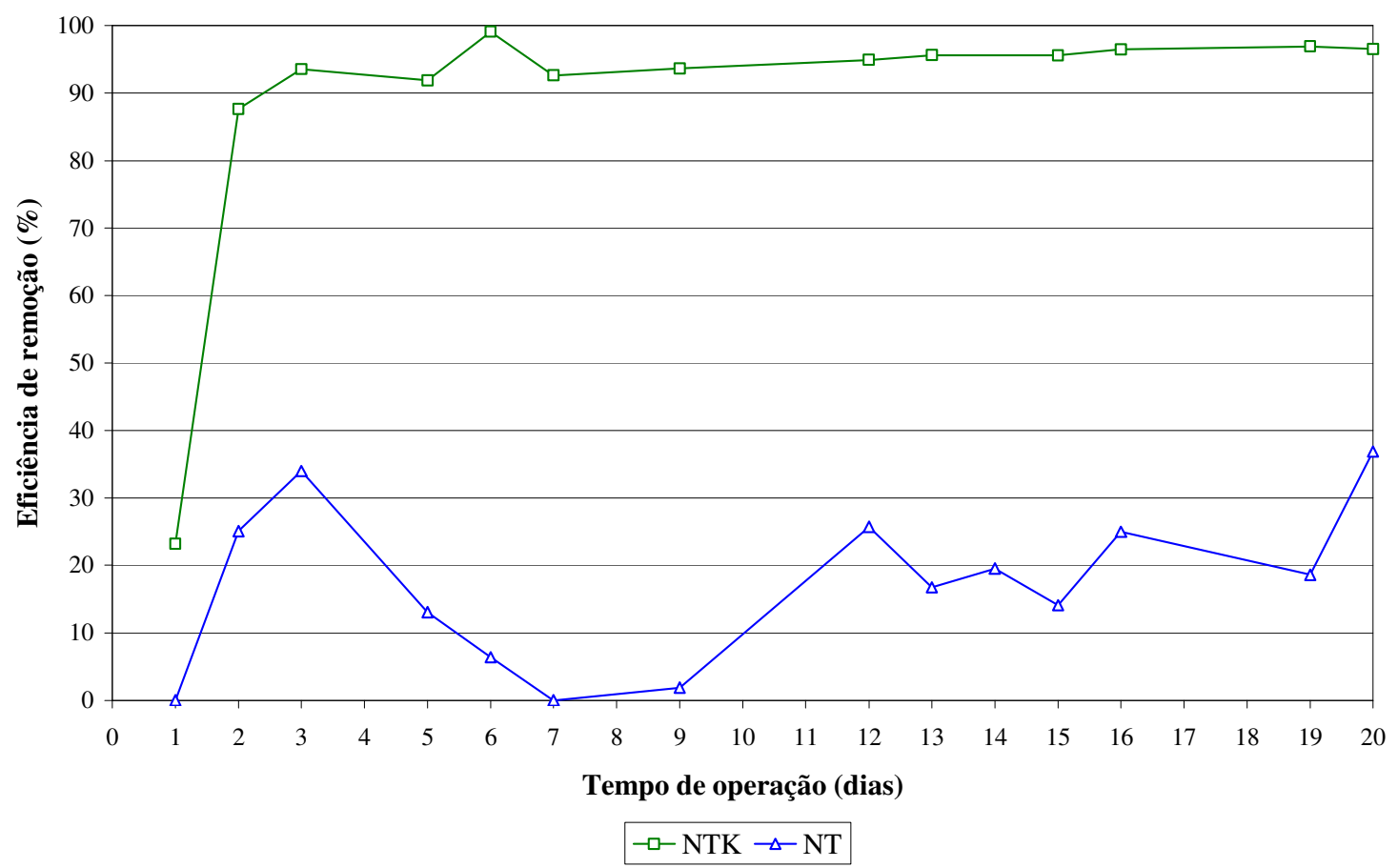

Figura 5.26 - Eficiência na remoção de NTK e NT ao longo do tempo de operação do sistema com reatores anaeróbio com aeração no topo e aeróbio verticais de leito fixo em série. 
O sistema foi alimentado com DQO média de $1436 \pm 50 \mathrm{mg} / \mathrm{l}$, apresentando DQO efluente aos reatores anaeróbio e aeróbio relativamente baixas, com valores médios de $209 \pm 37 \mathrm{mg} / \mathrm{l}$ e $26 \pm 21 \mathrm{mg} / \mathrm{l}$, respectivamente.

A eficiência média de remoção de DQO no reator anaeróbio com aeração no topo foi de $86 \pm 2 \%$, sendo que para a primeira etapa (reator apenas anaeróbio), considerando as mesmas condições operacionais, a eficiência média foi de $70 \pm 6 \%$. Essa diferença foi atribuída à aeração aplicada no topo do reator anaeróbio provocando a oxidação de parte da DQO efluente ao reator. Os possíveis processos envolvidos neste fenômeno são a oxidação química e/ou biológica da matéria orgânica remanescente e, em menor proporção devido às baixas concentrações de sulfato no afluente do reator, a oxidação do sulfeto formado no reator anaeróbio em sulfato, diminuindo a DQO efluente. Assim, se o objetivo do tratamento fosse remover apenas a matéria orgânica afluente, possivelmente não seria necessário encaminhar o efluente do reator anaeróbio para um pós-tratamento no reator aeróbio, bastando apenas aplicar aeração no topo do reator anaeróbio.

Com relação às concentrações de ácidos voláteis totais (AVT), o afluente apresentou valor médio de $328 \pm 73 \mathrm{mg} \mathrm{HAc/l}$, enquanto os efluentes dos reatores anaeróbio com aeração no topo e aeróbio apresentaram valores médios de $58 \pm 19 \mathrm{mg}$ HAc/l e $36 \pm 8 \mathrm{mg} \mathrm{HAc/l,} \mathrm{respectivamente.}$

Nas Figuras 5.27 e 5.28 são apresentados, respectivamente, os valores de DQO e AVT na alimentação e no efluente dos reatores anaeróbio e aeróbio ao longo do tempo de operação do sistema. 


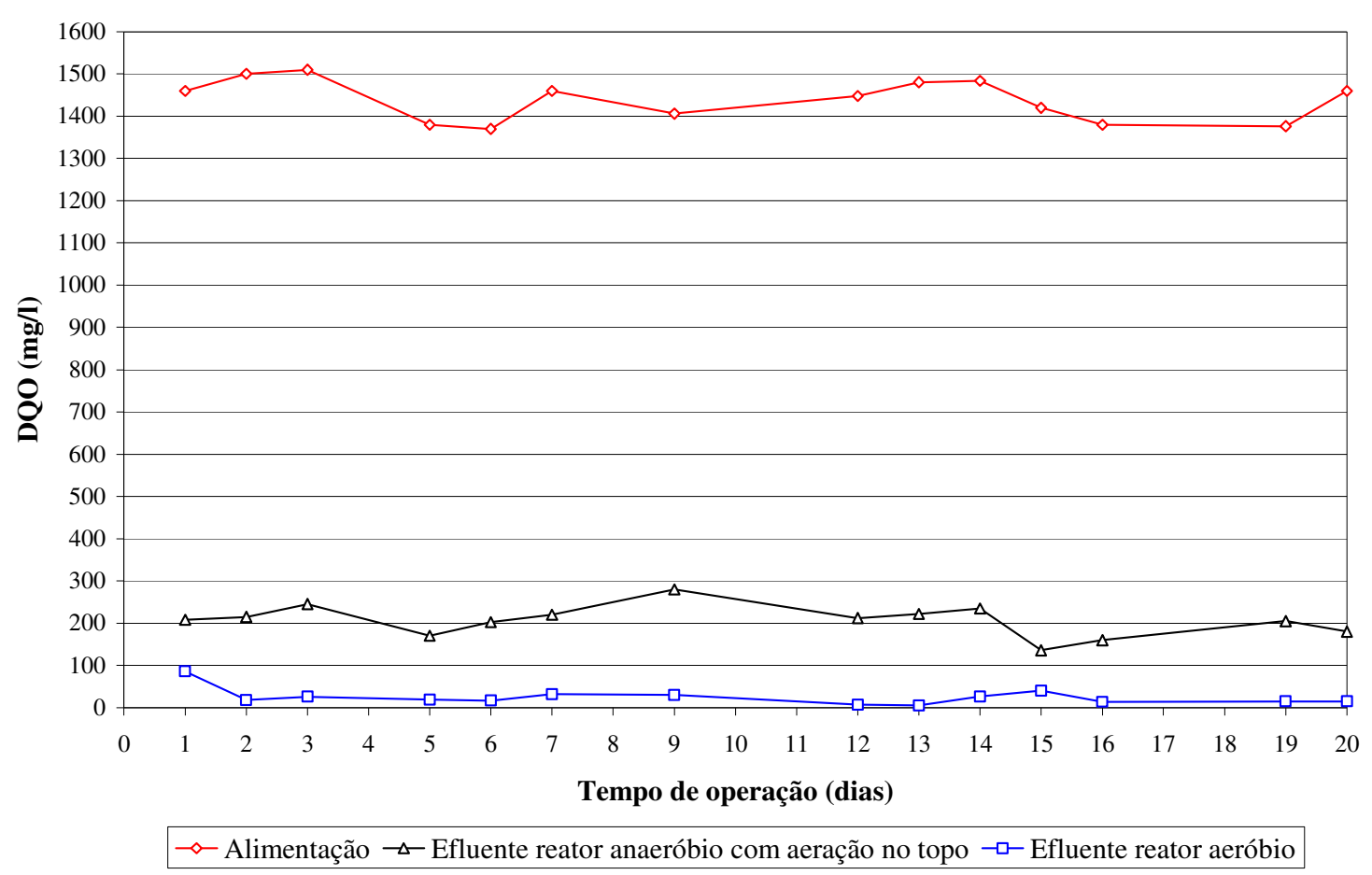

Figura 5.27 - DQO na alimentação e nos efluentes dos reatores anaeróbio com aeração no topo e aeróbio verticais de leito fixo ao longo do tempo de operação do sistema.

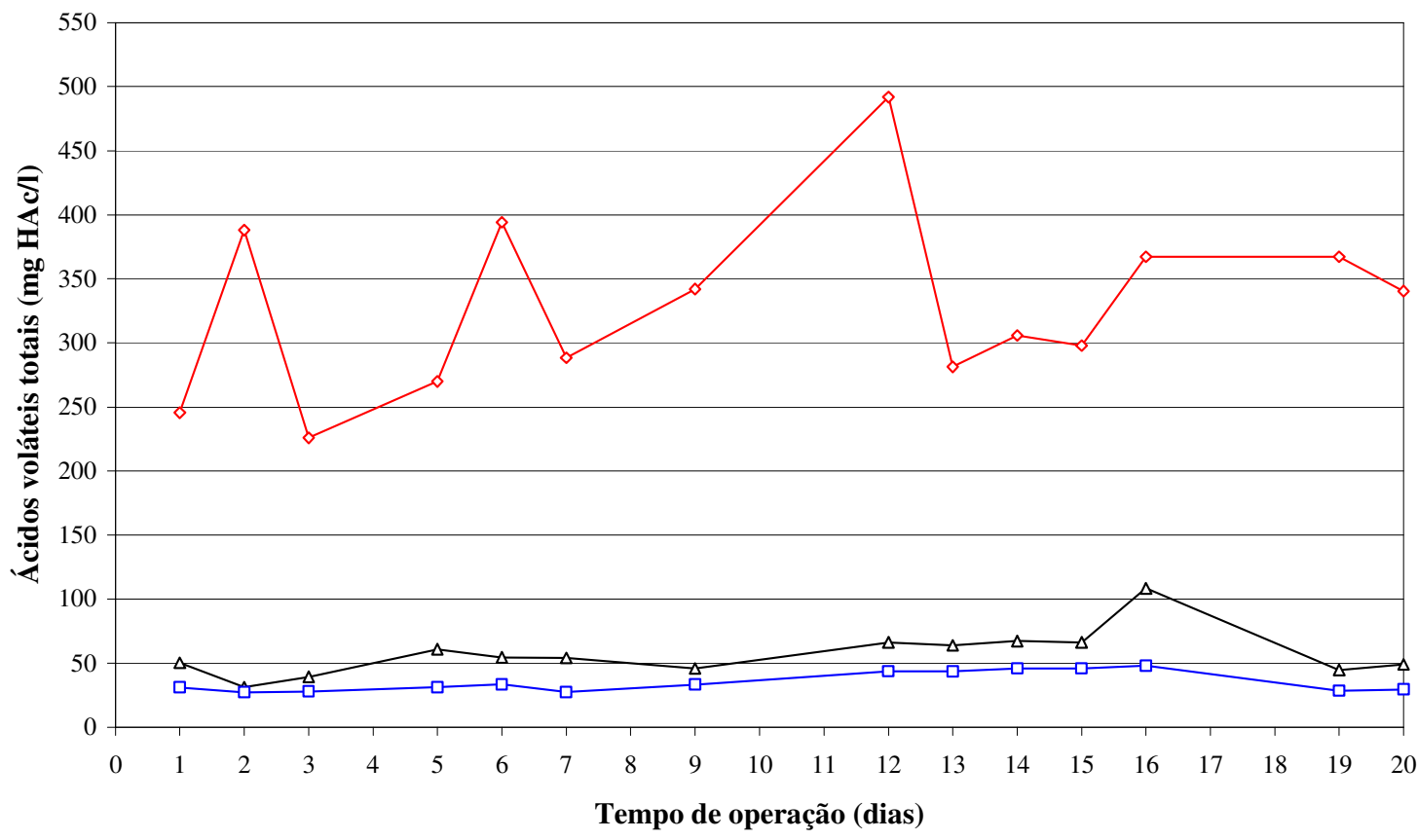

$\multimap$ Alimentação $\neg$ Efluente reator anaeróbio com aeração no topo $\rightarrow \square$ Efluente reator aeróbio

Figura 5.28 - Ácidos voláteis totais na alimentação e nos efluentes dos reatores anaeróbio com aeração no topo e aeróbio verticais de leito fixo ao longo do tempo de operação do sistema. 
A partir do $9^{\circ}$ dia de operação, observou-se aumento nas concentrações de $\mathrm{N}$ nitrito e N-nitrato no efluente do reator anaeróbio com aeração no topo, passando de concentrações médias de $0 \pm 0 \mathrm{mg} \mathrm{N}-\mathrm{NO}_{2}{ }^{-} / 1$ e $4 \pm 1 \mathrm{mg} \mathrm{N}-\mathrm{NO}_{3}{ }^{-} / 1$ nos primeiros 8 dias de operação para concentrações médias de $20 \pm 9 \mathrm{mg} \mathrm{N}-\mathrm{NO}_{2}{ }^{-} / \mathrm{l}$ e $30 \pm 14 \mathrm{mg} \mathrm{N}-\mathrm{NO}_{3}{ }^{-} / \mathrm{l}$ após o $9^{\circ}$ dia. Esse fenômeno mostrou que a aeração no topo do reator anaeróbio favoreceu, embora de forma não controlada, o crescimento de organismos nitrificantes neste reator. Assim, o topo do reator funcionava como um reator aeróbio sem suporte para a imobilização celular, operando com baixo tempo de detenção hidráulica.

A concentração média de NTK na alimentação do reator anaeróbio com aeração no topo foi de $174 \pm 25 \mathrm{mg} \mathrm{N} / \mathrm{l}$, com $46 \%$ do nitrogênio na forma orgânica e $56 \%$ na forma amoniacal. Para o seu efluente, as concentrações médias de NTK e N-amoniacal foram de $138 \pm 34 \mathrm{mg} \mathrm{N} / \mathrm{l} \mathrm{e} 106 \pm 32 \mathrm{mg} \mathrm{N} / \mathrm{l}$, respectivamente.

A atividade nitrificante no reator aeróbio foi evidenciada a partir do $2^{\circ}$ dia de operação, com a queda acentuada da concentração de NTK no seu efluente. Deste dia em diante, a maior parte do nitrogênio efluente apresentou-se na forma de $\mathrm{N}$-nitrato

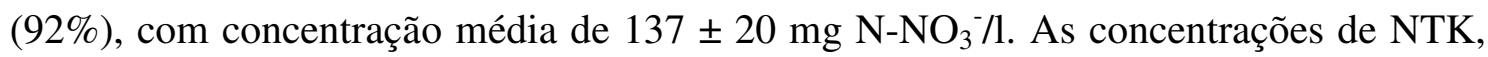
$\mathrm{N}$-amoniacal e $\mathrm{N}$-nitrito efluentes mantiveram-se baixas, com valores médios de $10 \pm 6$ $\mathrm{mg} \mathrm{N} / \mathrm{l}, 1 \pm 0 \mathrm{mg} \mathrm{N}-\mathrm{NH}_{4}{ }^{+} / 1$ e $1 \pm 1 \mathrm{mg} \mathrm{N}^{-N_{2}}{ }_{2}^{-} / 1$, respectivamente.

Na Figura 5.29 são apresentados os valores de NTK na alimentação e no efluente dos reatores anaeróbio com aeração no topo e aeróbio ao longo do tempo de operação do sistema. As concentrações de $\mathrm{N}$-amoniacal, N-nitrato e N-nitrito efluentes aos reatores anaeróbio com aeração no topo e aeróbio ao longo do tempo de operação do sistema são apresentadas, respectivamente, nas Figuras 5.30 e 5.31. 


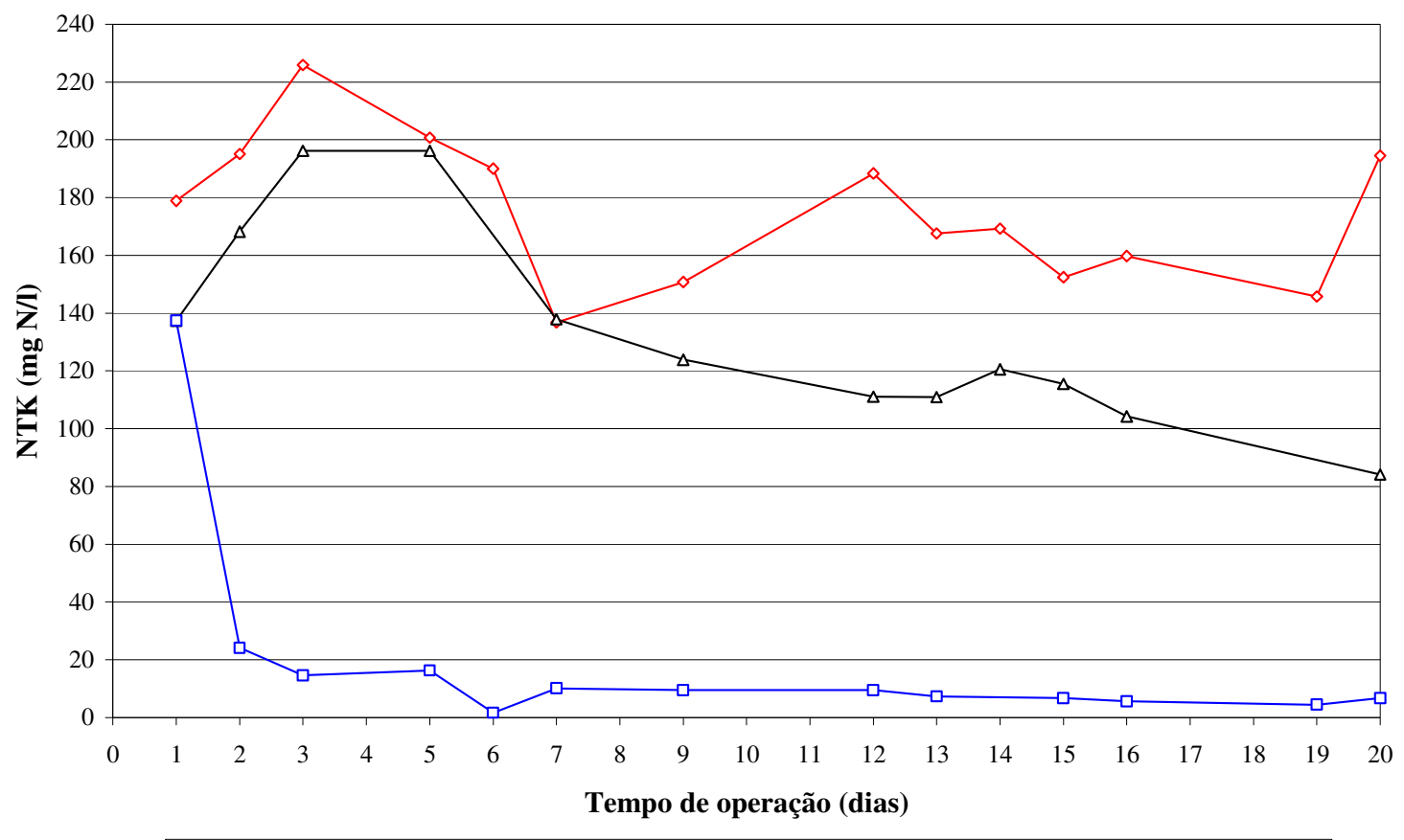

$\neg$ Alimentação $\rightarrow-$ Efluente reator anaeróbio com aeração no topo $-\square-$ Efluente reator aeróbio

Figura 5.29 - NTK na alimentação e no efluente dos reatores anaeróbio com aeração no topo e aeróbio verticais de leito fixo ao longo do tempo de operação do sistema.

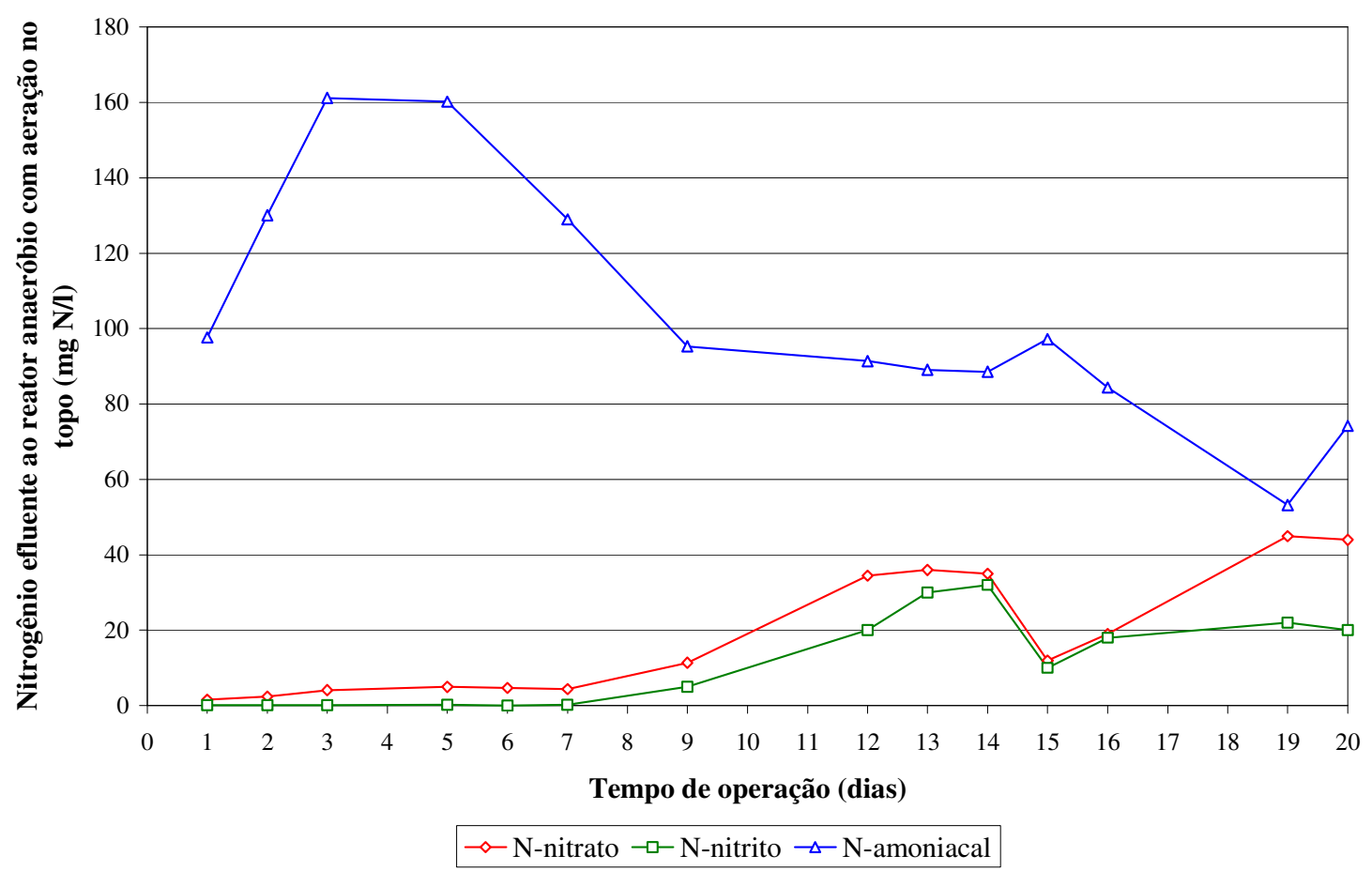

Figura 5.30 - Concentrações de N-amoniacal, N-nitrito e N-nitrato no efluente do reator anaeróbio vertical de leito fixo com aeração no topo ao longo do tempo de operação. 


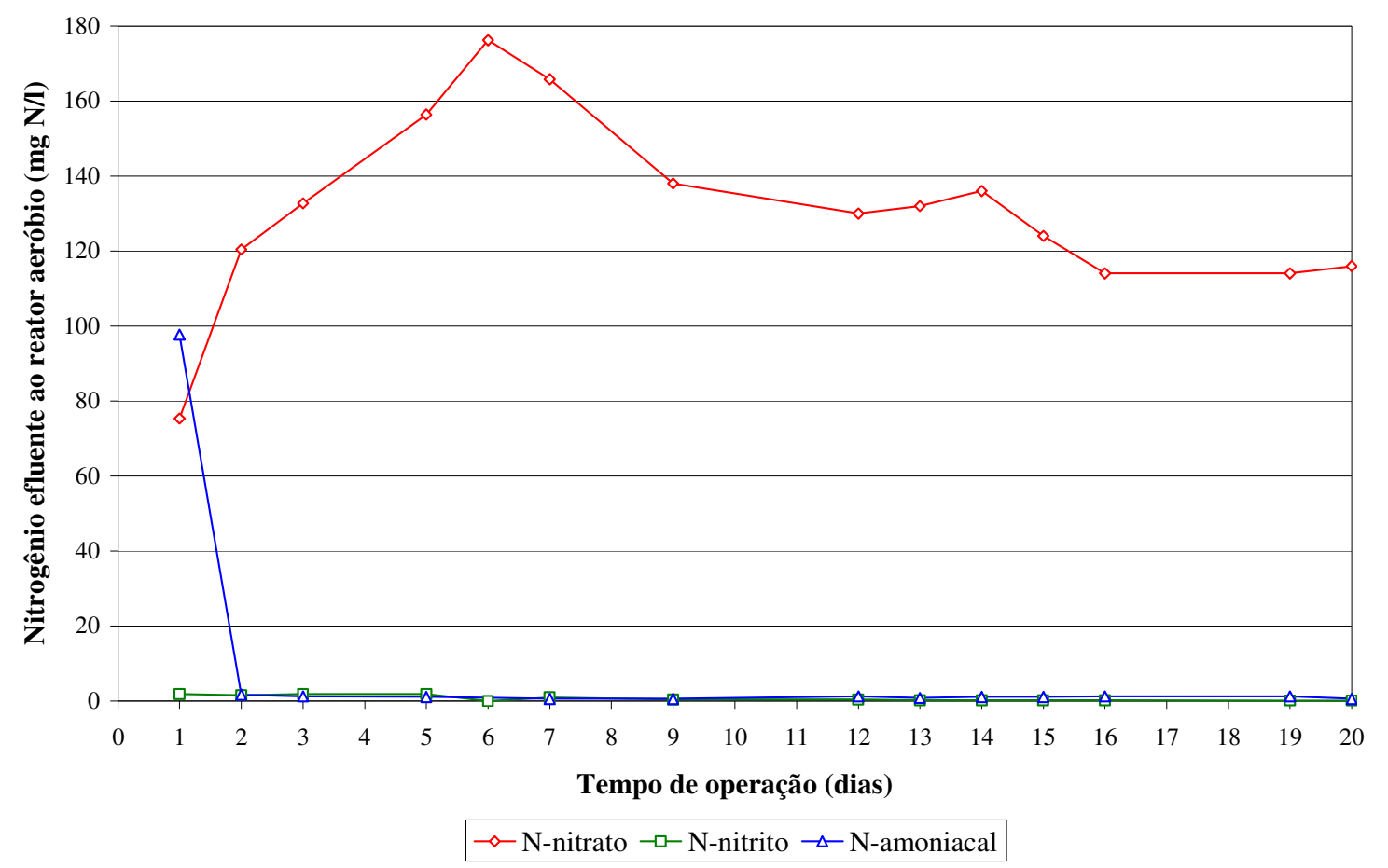

Figura 5.31 - Concentrações de N-amoniacal, N-nitrito e N-nitrato no efluente do reator aeróbio vertical de leito fixo ao longo do tempo de operação.

Como pode ser observado na Figura 5.32, devido à baixa eficiência na remoção de NT apresentada pelo sistema após a separação dos módulos anaeróbios e aeróbios $(17 \pm 10 \%)$, as concentrações de NT na alimentação e nos efluentes dos reatores anaeróbio com aeração no topo e aeróbio apresentaram valores médios próximos (174 \pm $25 \mathrm{mg} \mathrm{N} / 1,164 \pm 25 \mathrm{mg} \mathrm{N} / \mathrm{l} \mathrm{e} 152 \pm 27 \mathrm{mg} \mathrm{N} / \mathrm{l}$, respectivamente). 


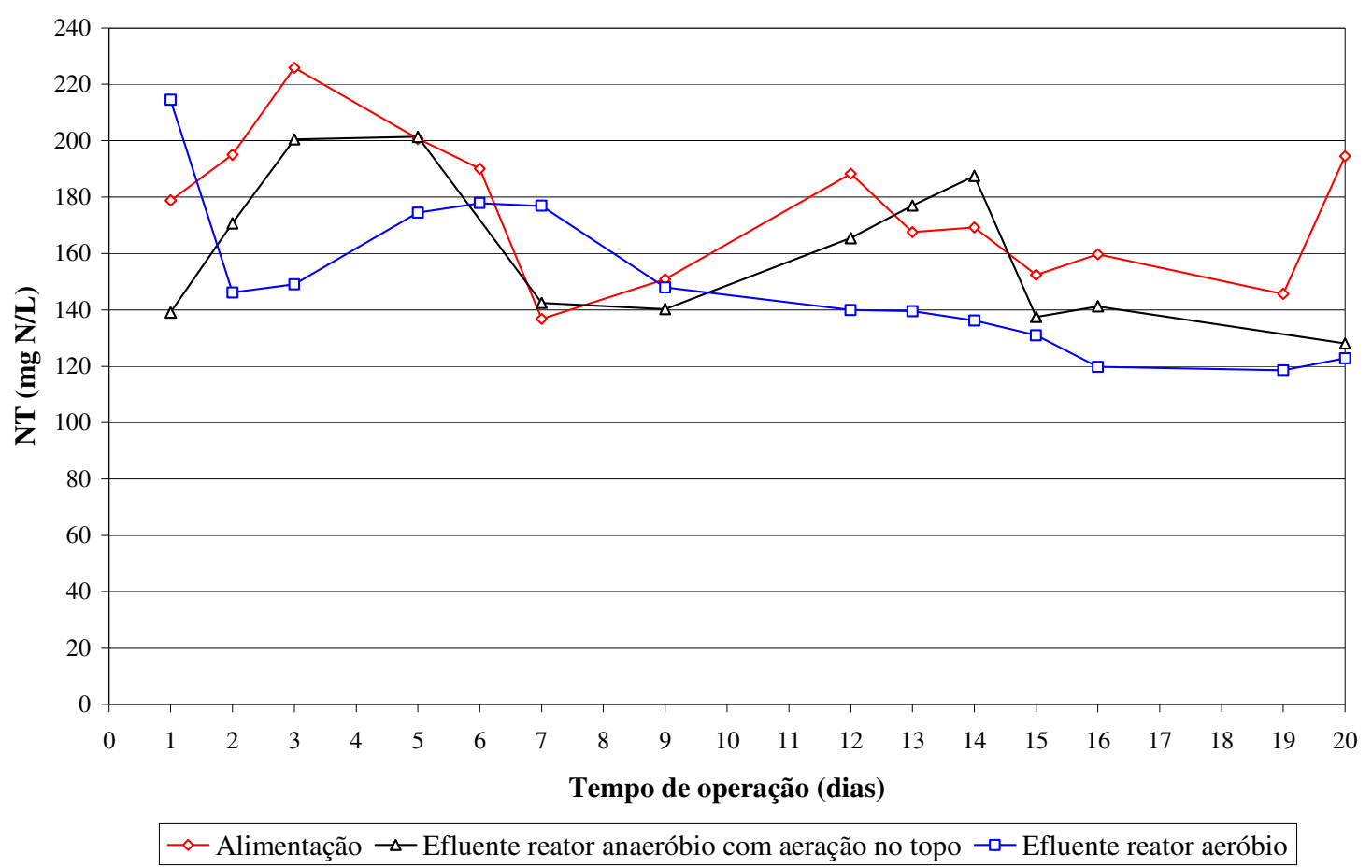

Figura 5.32 - Nitrogênio total (NT) na alimentação e nos efluentes dos reatores anaeróbio com aeração no topo e aeróbio verticais de leito fixo ao longo do tempo de operação do sistema.

Devido à atividade anaeróbia, o efluente do primeiro reator apresentou valor de alcalinidade superior à alcalinidade afluente durante todo o período de operação, sendo os valores médios iguais a $882 \pm 164 \mathrm{mg} \mathrm{CaCO}_{3} / \mathrm{l}$ e $663 \pm 110 \mathrm{mg} \mathrm{CaCO}_{3} / \mathrm{l}$, respectivamente. Por outro lado, devido ao consumo de alcalinidade na nitrificação, o reator aeróbio apresentou baixa concentração de alcalinidade efluente, com valor médio de $128 \pm 96 \mathrm{mg} \mathrm{CaCO}_{3} / \mathrm{l}$. Com relação ao $\mathrm{pH}$, os valores médios na alimentação do sistema e nos efluentes dos reatores anaeróbio com aeração no topo e aeróbio foram de $8,2 \pm 0,3,8,4 \pm 0,2$ e $7,8 \pm 0,5$, respectivamente.

Nas Figuras 5.33 e 5.34 são apresentados, respectivamente, os valores de alcalinidade a bicarbonato e pH na alimentação e no efluente dos reatores anaeróbio com aeração no topo e aeróbio ao longo do tempo de operação do sistema. 


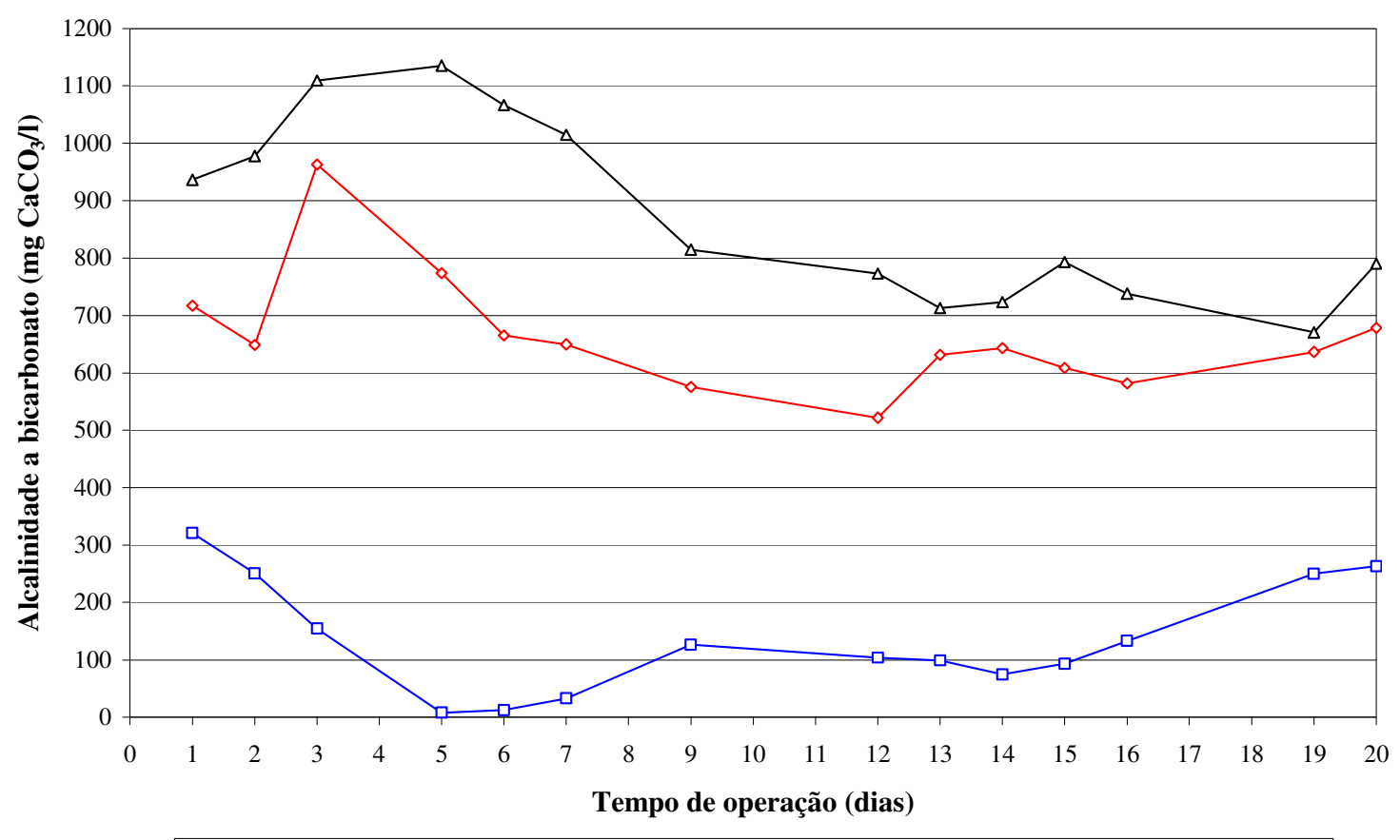

$\neg$ Alimentação $\rightarrow-$ Efluente reator anaeróbio com aeração no topo $-\square-$ Efluente reator aeróbio

Figura 5.33 - Alcalinidade a bicarbonato na alimentação e no efluente dos reatores anaeróbio e aeróbio verticais de leito fixo ao longo do tempo de operação do sistema.

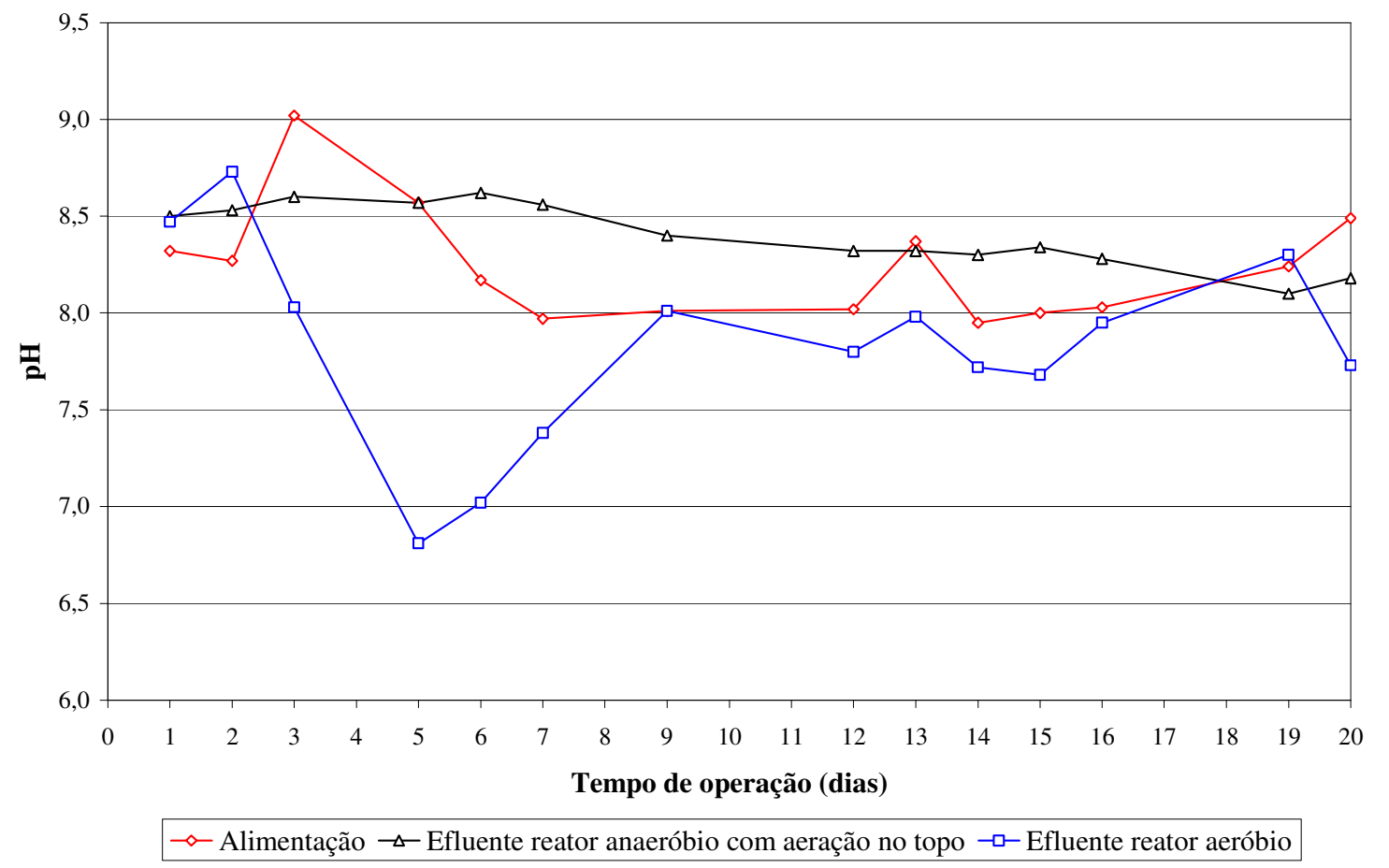

Figura 5.34 - pH na alimentação e no efluente dos reatores anaeróbio com aeração no topo e aeróbio verticais de leito fixo ao longo do tempo de operação do sistema. 
Durante todo o período operacional, a concentração de oxigênio dissolvido no reator aeróbio manteve-se alta, conforme apresentado no gráfico da Figura 5.35, com valor médio de $6,0 \pm 0,2 \mathrm{mg} \mathrm{O}_{2} / 1$.

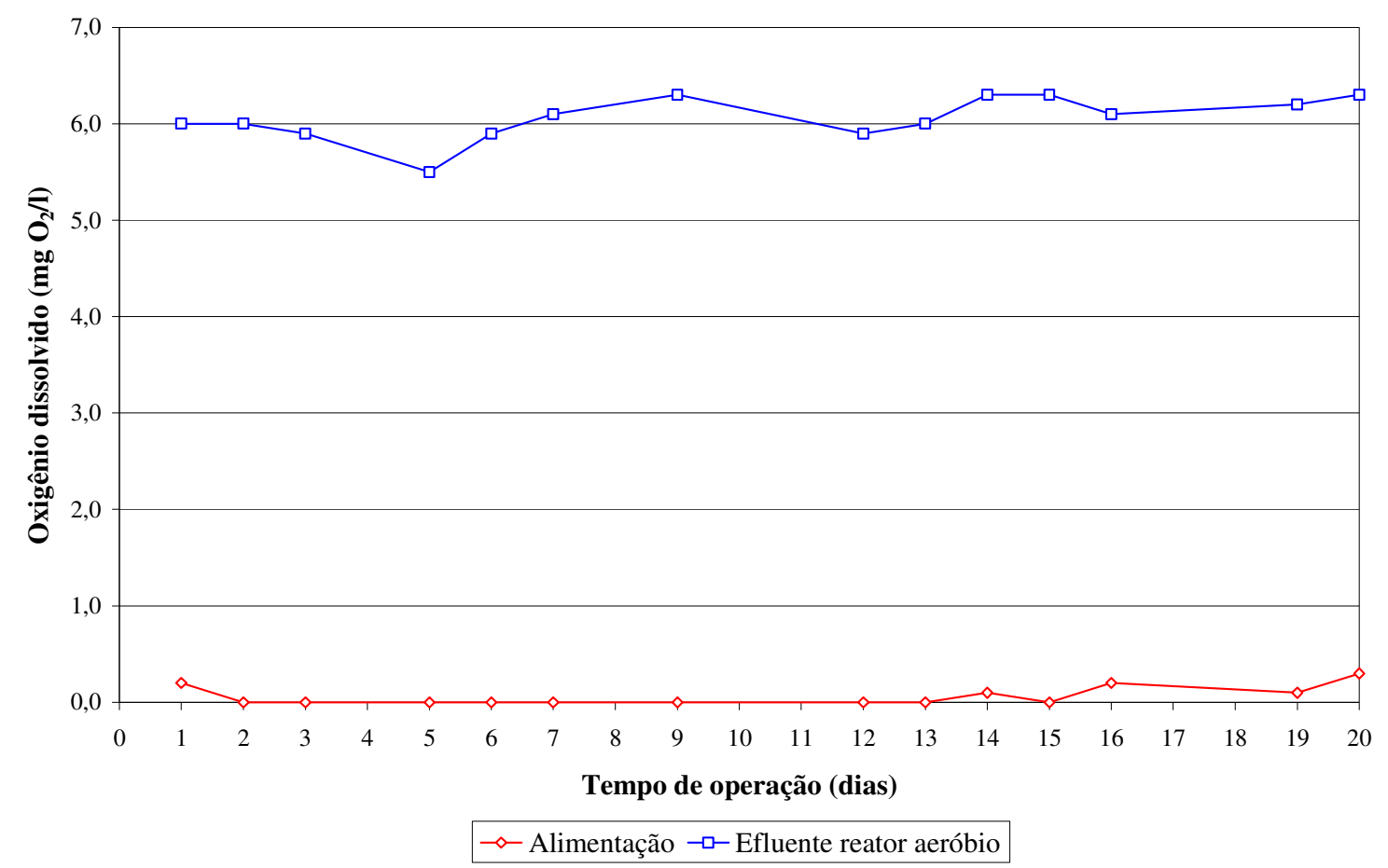

Figura 5.35 - Oxigênio dissolvido na alimentação e no efluente do reator aeróbio vertical de leito fixo ao longo do tempo de operação do sistema.

Após a separação das zonas anaeróbia e aeróbia em dois reatores distintos, o sistema apresentou eficiências médias de remoção de DQO, SST e NTK ligeiramente superiores às observadas para o sistema com reatores conjugados (etapa 2). Por outro lado, a eficiência do sistema na remoção de NT decresceu significativamente, evidenciando a queda na atividade desnitrificante após a separação dos módulos. $\mathrm{Na}$ Tabela 5.6 é apresentado o comparativo entre as eficiências alcançadas na remoção de DQO, SST, NTK e NT para os sistemas combinados anaeróbio-aeróbio com reatores conjugados e separados. 
Tabela 5.6 - Eficiências alcançadas na remoção de DQO, SST, NTK e NT para os sistemas combinados anaeróbio-aeróbio com reatores conjugados e separados.

\begin{tabular}{ccc}
\hline $\begin{array}{c}\text { Eficiência de remoção } \\
(\%)\end{array}$ & $\begin{array}{c}\text { Reatores conjugados } \\
\text { (etapa 2) }\end{array}$ & $\begin{array}{c}\text { Reatores separados } \\
\text { (etapa 3) }\end{array}$ \\
\hline DQO & $96 \pm 2$ & $99 \pm 1$ \\
SST & $84 \pm 11$ & $94 \pm 3$ \\
NTK & $84 \pm 11$ & $94 \pm 3$ \\
NT & $61 \pm 13$ & $17 \pm 10$ \\
\hline
\end{tabular}

A principal diferença entre as configurações utilizadas na segunda e terceira etapas experimentais foi a destinação dos gases gerados no reator anaeróbio. Para a primeira situação, como os reatores anaeróbio e aeróbio eram sobrepostos, os gases formados na zona anaeróbia passavam obrigatoriamente pela zona aeróbia antes de sair para a atmosfera. No caso do sistema com reatores separados esse gás era liberado no topo do próprio reator anaeróbio, sem passar pelo reator aeróbio.

Segundo Madigan et al (1997), na presença de oxigênio, alguns organismos são capazes de converter metano em compostos intermediários como metanol e formaldeido, utilizados pelas bactérias desnitrificantes como doadores de elétrons para a redução do nitrato a nitrogênio gasoso. Foresti et al. (2006) ressalta que além do metano, os compostos reduzidos de enxofre, principalmente o $\mathrm{H}_{2} \mathrm{~S}$, também podem ser utilizados como doadores de elétrons na desnitrificação.

Assim, a principal hipótese levantada para explicar a alta eficiência de desnitrificação obtida com os reatores conjugados relaciona-se à possibilidade dos gases gerados no reator anaeróbio, principalmente $\mathrm{CH}_{4}$ e $\mathrm{H}_{2} \mathrm{~S}$, terem sido utilizados como doadores de elétrons para a redução do nitrato a nitrogênio gasoso no reator aeróbio. A atividade desnitrificante ocorreria no interior da biopartícula, onde as concentrações de oxigênio dissolvido seriam menores que no meio líquido. No caso dos reatores separados, como o gás não era encaminhado para o reator aeróbio, o metabolismo desnitrificante provavelmente teve como limitante a baixa concentração de doadores de elétrons compatíveis, tais como, matéria orgânica facilmente biodegradável, metano e sulfeto.

O aumento de eficiência na remoção de DQO, SST e NTK apresentado na etapa 3 (reatores separados) não foi associado a nenhum parâmetro operacional. A hipótese mais relevante que explica o fato é de que o reator aeróbio, antes de ser desacoplado do 
reator anaeróbio, foi esgotado e com isso teve o seu leito reacional reorganizado, descompactando os suportes e melhorando a hidrodinâmica no reator. Assim, com a melhora da hidráulica do sistema, obteve-se um aumento na remoção de matéria orgânica e nitrificação, além de melhorar a retenção de sólidos.

Os resultados médios de todos os parâmetros analisados durante a operação do sistema com reatores anaeróbio e aeróbio verticais de leito fixo em série são apresentados na Tabela 5.7.

Tabela 5.7 - Resultados médios dos parâmetros analisados durante a operação do sistema com reatores anaeróbio e aeróbio verticais de leito fixo em série.

\begin{tabular}{|c|c|c|c|}
\hline Parâmetros & $\begin{array}{l}\text { Alimentação } \\
\text { do sistema }^{\mathrm{d}}\end{array}$ & $\begin{array}{c}\text { Efluente reator } \\
\text { anaeróbio com } \\
\text { aeração no topo }\end{array}$ & $\begin{array}{c}\text { Efluente reator } \\
\text { aeróbio }^{\mathrm{d}}\end{array}$ \\
\hline Temperatura $\left({ }^{\circ} \mathrm{C}\right)$ & $24,8 \pm 1,8$ & - & $29,4 \pm 0,5$ \\
\hline $\mathrm{pH}$ & $8,2 \pm 0,3$ & $8,4 \pm 0,2$ & $7,8 \pm 0,5$ \\
\hline $\mathrm{OD}^{\mathrm{a}}\left(\mathrm{mg} \mathrm{O}_{2} / \mathrm{l}\right)$ & $0,0 \pm 0,1$ & - & $6,0 \pm 0,2$ \\
\hline $\mathrm{AB}^{\mathrm{b}}\left(\mathrm{mg} \mathrm{CaCO} \mathrm{Ca}_{3} / \mathrm{l}\right)$ & $663 \pm 110$ & $882 \pm 164$ & $128 \pm 96$ \\
\hline DQO bruta $\left(\mathrm{mg} \mathrm{O}_{2} / \mathrm{l}\right)$ & $1436 \pm 50$ & $209 \pm 37$ & $26 \pm 21$ \\
\hline DQO filtrada $\left(\mathrm{mg} \mathrm{O}_{2} / \mathrm{l}\right)$ & $1118 \pm 137$ & - & $15 \pm 9$ \\
\hline $\mathrm{AVT}^{\mathrm{c}}(\mathrm{mg} \mathrm{HAc} / \mathrm{l})$ & $328 \pm 73$ & $58 \pm 19$ & $36 \pm 8$ \\
\hline NTK (mg N/l) & $174 \pm 25$ & $138 \pm 34$ & $10 \pm 6$ \\
\hline $\mathrm{N}-\mathrm{NH}_{4}^{+}(\mathrm{mg} \mathrm{N} / \mathrm{l})$ & $94 \pm 21$ & $106 \pm 32$ & $1 \pm 0$ \\
\hline N-org (mg N/l) & $76 \pm 18$ & $27 \pm 10$ & $12 \pm 11$ \\
\hline $\mathrm{N}-\mathrm{NO}_{2}^{-}(\mathrm{mg} \mathrm{N} / \mathrm{l})$ & - & $11 \pm 12$ & $1 \pm 1$ \\
\hline $\mathrm{N}-\mathrm{NO}_{3}{ }^{-}(\mathrm{mg} \mathrm{N} / \mathrm{l})$ & - & $17 \pm 16$ & $137 \pm 20$ \\
\hline $\mathrm{ST}(\mathrm{mg} / \mathrm{l})$ & $1343 \pm 275$ & - & $1162 \pm 80$ \\
\hline $\mathrm{SST}(\mathrm{mg} / \mathrm{l})$ & $190 \pm 54$ & - & $13 \pm 13$ \\
\hline $\mathrm{SSV}(\mathrm{mg} / \mathrm{l})$ & $180 \pm 58$ & - & $12 \pm 14$ \\
\hline \multicolumn{4}{|c|}{${ }^{\mathrm{a}}$ OD: Oxigênio dissolvido } \\
\hline \multicolumn{4}{|c|}{${ }^{\mathrm{b}} \mathrm{AB}$ : Alcalinidade a bicarbonato } \\
\hline \multicolumn{4}{|c|}{${ }^{\mathrm{c}}$ AVT: Ácidos voláteis totais } \\
\hline
\end{tabular}




\subsection{ETAPA 4 - REATOR COMBINADO ANAERÓBIO-AERÓBIO VERTICAL DE LEITO FIXO COM RECIRCULAÇÃO INTERNA DE EFLUENTE TRATADO}

Nesta etapa experimental, operou-se o reator combinado anaeróbio-aeróbio vertical de leito fixo com diferentes vazões de recirculação interna de efluente tratado (Qr), avaliando-se o desempenho do sistema durante 101 dias, com temperatura controlada em $30 \pm 1^{\circ} \mathrm{C}$. A vazão de alimentação do reator (Q) foi mantida constante ao longo de toda operação, com valor de 0,8 1/h, analogamente à etapa 2 , com TDH total de $35 \mathrm{~h}$, baseado no volume útil do reator, sendo $21 \mathrm{~h}$ na zona anaeróbia e 14 h na zona aeróbia.

Iniciou-se a operação do reator combinado anaeróbio-aeróbio vertical de leito fixo aplicando-se vazão de recirculação de 0,4 l/h, equivalente a razão de recirculação $(\mathrm{R}=\mathrm{Qr} / \mathrm{Q})$ de 0,5 . Nesta condição o sistema permaneceu por 19 dias, obtendo eficiências médias na remoção de DQO, SST, NTK e NT iguais a $98 \pm 1 \%, 97 \pm 2 \%, 95 \pm 2 \%$ e 42 $\pm 8 \%$, respectivamente.

No $20^{\circ}$ dia de operação aumentou-se a vazão de recirculação para $0,8 \mathrm{l} / \mathrm{h}$, passando de 0,5 para 1,0 a razão de recirculação. Operou-se o sistema nessa condição por 34 dias e as eficiências médias alcançadas na remoção de DQO, SST, NTK e NT foram de $98 \pm 1 \%, 94 \pm 3 \%, 92 \pm 3 \%$ e $54 \pm 11 \%$, respectivamente.

Durante os dias $54^{\circ}$ e $76^{\circ}$ a bomba de recirculação interna foi desligada, fazendo com que não houvesse retorno de efluente tratado para o reator anaeróbio $(\mathrm{R}=0)$, alcançando eficiências médias de $99 \pm 1 \%, 94 \pm 3 \%, 94 \pm 2 \%$ e $17 \pm 11 \%$ na remoção de DQO, SST, NTK e NT, respectivamente.

Por fim, entre os dias $77^{\circ}$ e $101^{\circ}$ o reator foi operado com Qr igual a 2,8 1/h $(\mathrm{R}=3,5)$, apresentando eficiências médias na remoção de DQO, SST, NTK e NT de $97 \pm$ $1 \%, 88 \pm 6 \%, 94 \pm 2 \%$ e $77 \pm 16 \%$, respectivamente.

Na Figura 5.36 são apresentados os valores de eficiência na remoção de DQO (demanda química de oxigênio) e SST (sólidos em suspensão totais), enquanto que na Figura 5.37 é apresentado o perfil de eficiência na remoção de NTK (nitrogênio total Kjeldahl) e NT (nitrogênio total), ao longo do tempo de operação do reator combinado anaeróbio-aeróbio vertical de leito fixo para cada razão de recirculação aplicada. 


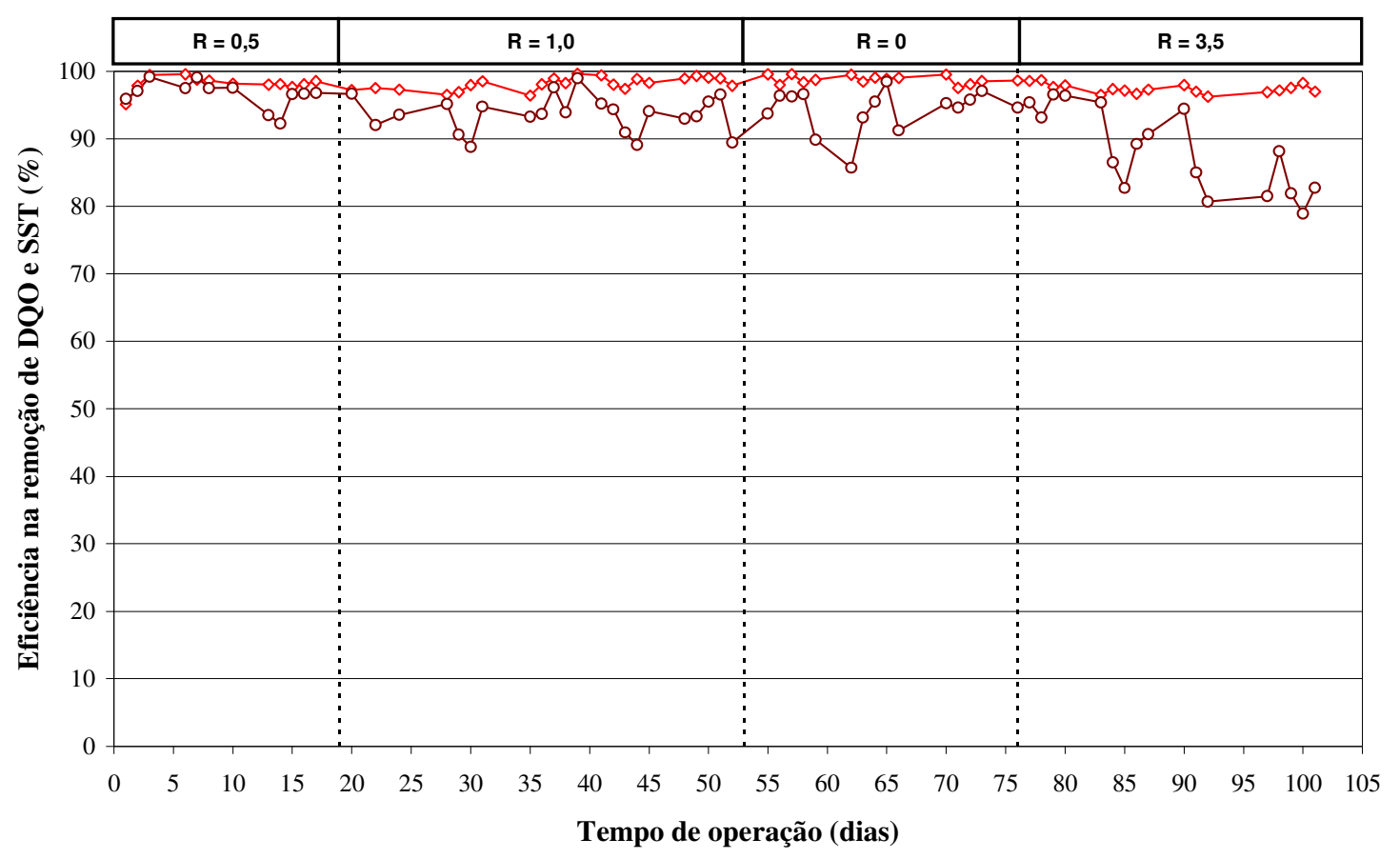

$$
\multimap \text { DQO } \multimap-\text { SST }
$$

Figura 5.36 - Eficiência na remoção de DQO e SST ao longo do tempo de operação do reator combinado anaeróbio-aeróbio vertical de leito fixo, para cada razão de recirculação $(\mathrm{R})$ aplicada.

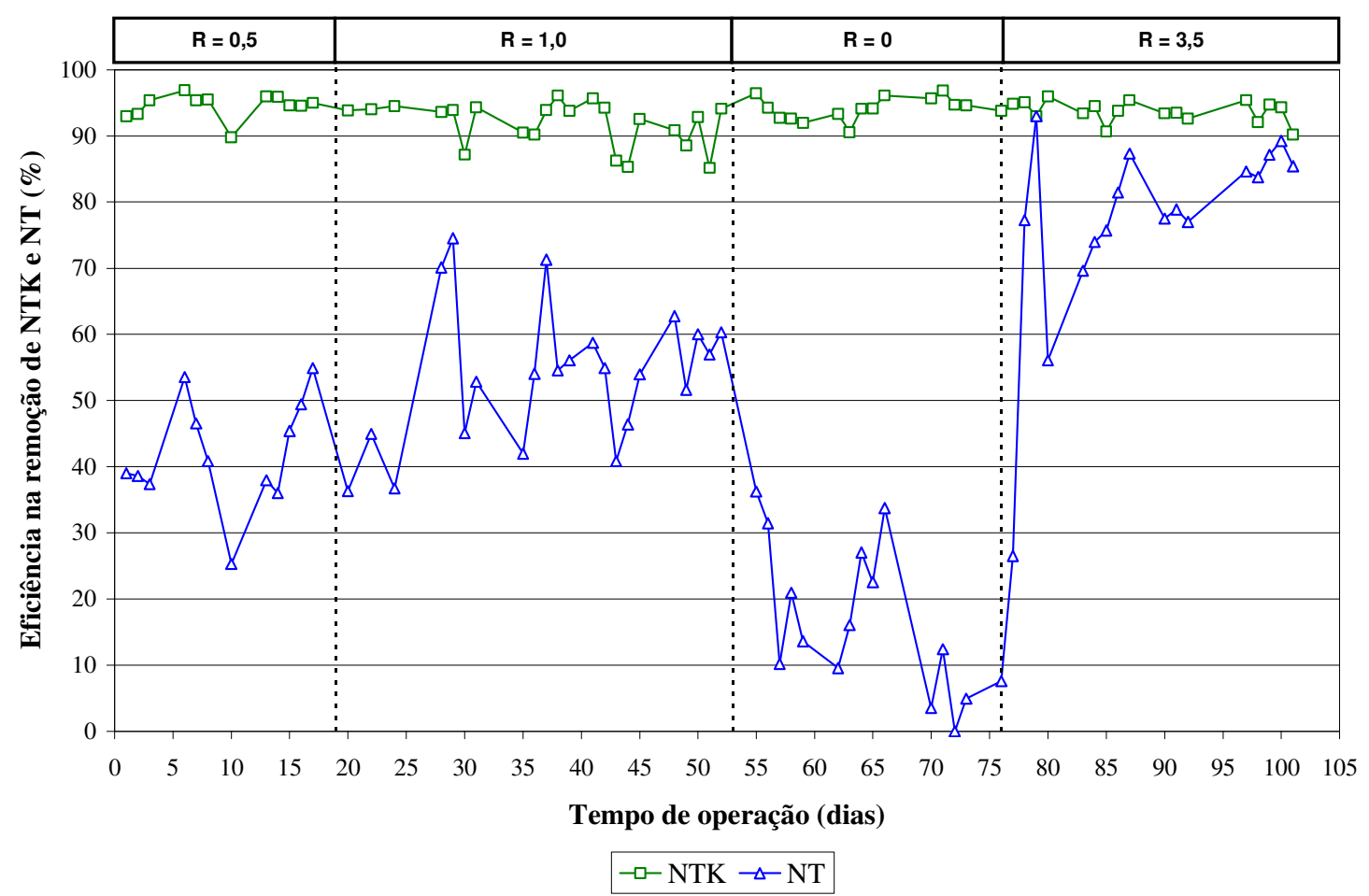

Figura 5.37 - Eficiência na remoção de NTK e NT ao longo do tempo de operação do reator combinado anaeróbio-aeróbio vertical de leito fixo, para cada razão de recirculação (R) aplicada. 
O reator combinado anaeróbio-aeróbio vertical de leito fixo apresentou efluente tratado com baixo valor de DQO, para todas as condições de recirculação empregadas, com valor médio de $27 \pm 14 \mathrm{mg} / \mathrm{l}$. Analogamente, as concentrações de sólidos em suspensão efluentes também permaneceram baixas ao longo da operação, com concentrações médias de $11 \pm 6 \mathrm{mg} \mathrm{SST/1}$ e $8 \pm 5 \mathrm{mg} \mathrm{SSV} / 1$. Devido à boa retenção de sólidos no sistema, a DQO filtrada efluente apresentou-se muito próxima à DQO bruta, com valor médio de $21 \pm 13 \mathrm{mg} / \mathrm{l}$. Na alimentação, a DQO permaneceu praticamente constante ao longo da operação do reator, com valor médio de $1423 \pm 76 \mathrm{mg} / \mathrm{l}$, enquanto que as concentrações de sólidos em suspensão tiveram maior variação, com valores médios de $176 \pm 61 \mathrm{mg} \mathrm{SST/1}$ e $162 \pm 56 \mathrm{mg}$ SSV/1. Nas Figuras 5.38 e 5.39 são apresentados, respectivamente, os valores de DQO e SST durante a operação do reator combinado anaeróbio-aeróbio vertical de leito fixo para cada razão de recirculação aplicada.

Na Figura 5.40 é apresentado o gráfico Box-plot de distribuição dos resultados de DQO afluente e efluente para cada razão de recirculação $(\mathrm{R})$ aplicada.

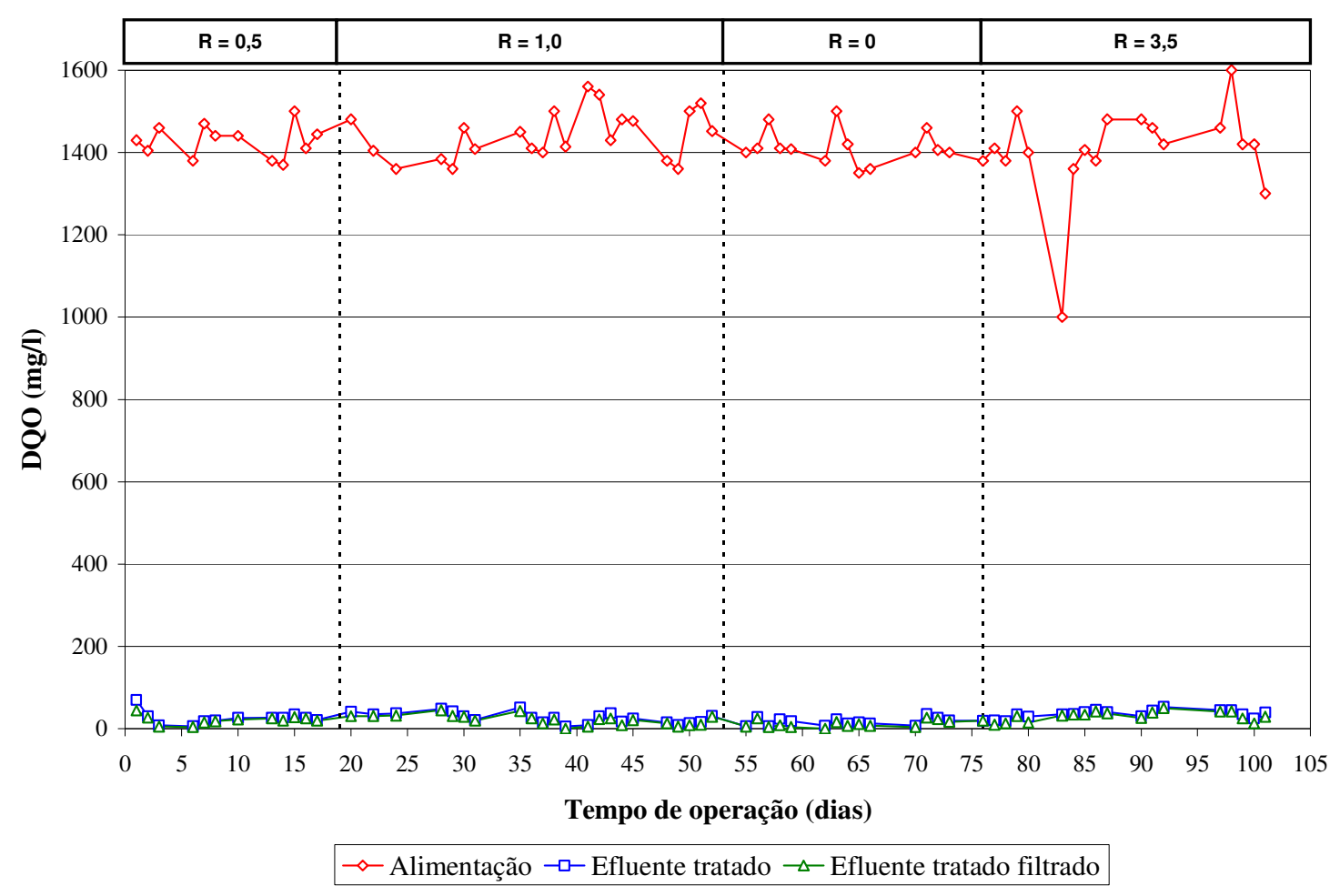

Figura 5.38 - DQO na alimentação, no efluente tratado e no efluente tratado filtrado do reator combinado anaeróbio-aeróbio vertical de leito fixo ao longo do tempo de operação, para cada razão de recirculação $(\mathrm{R})$ aplicada. 


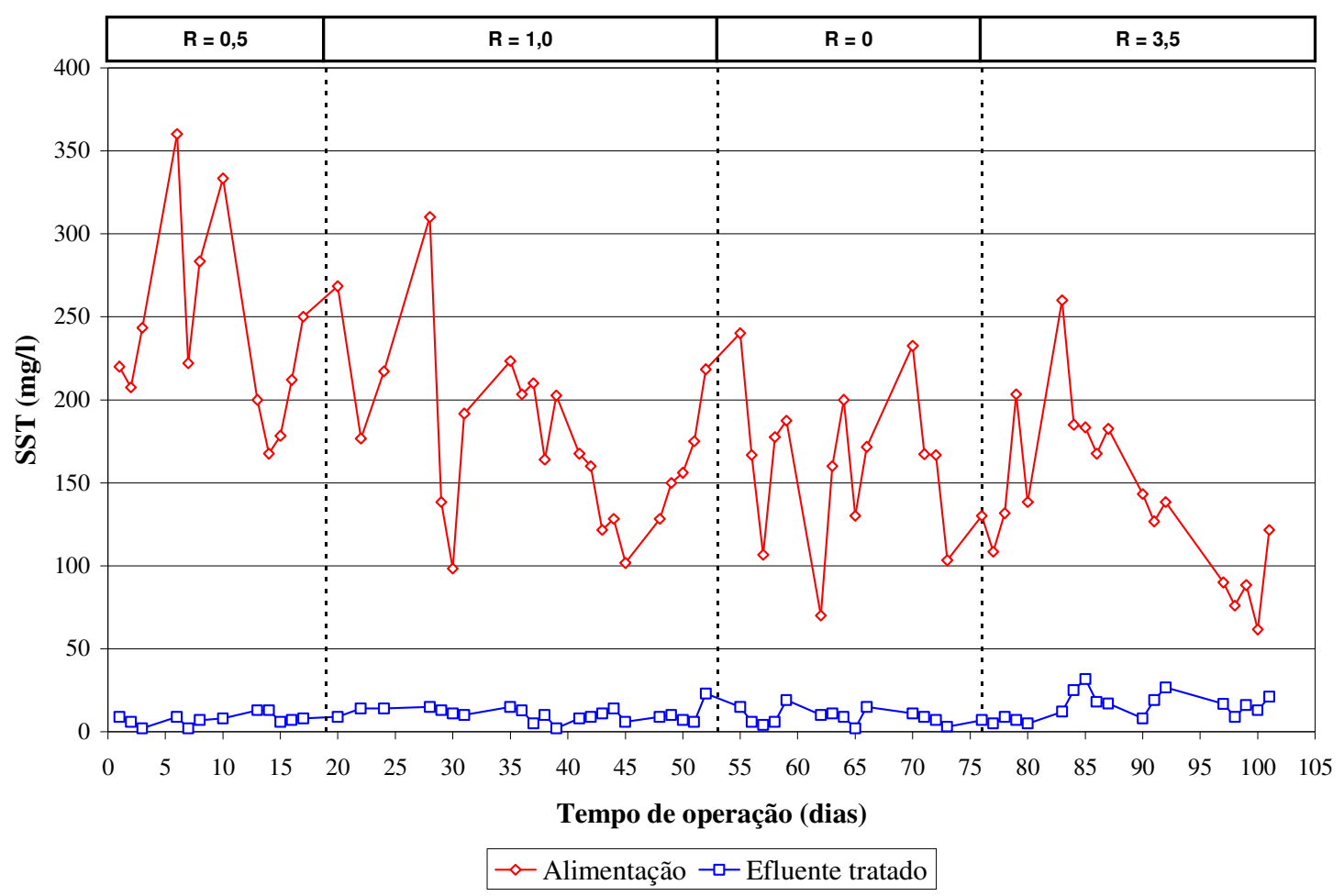

Figura 5.39 - Sólidos suspensos totais (SST) na alimentação e no efluente tratado do reator combinado anaeróbio-aeróbio vertical de leito fixo ao longo do tempo de operação, para cada razão de recirculação (R) aplicada.

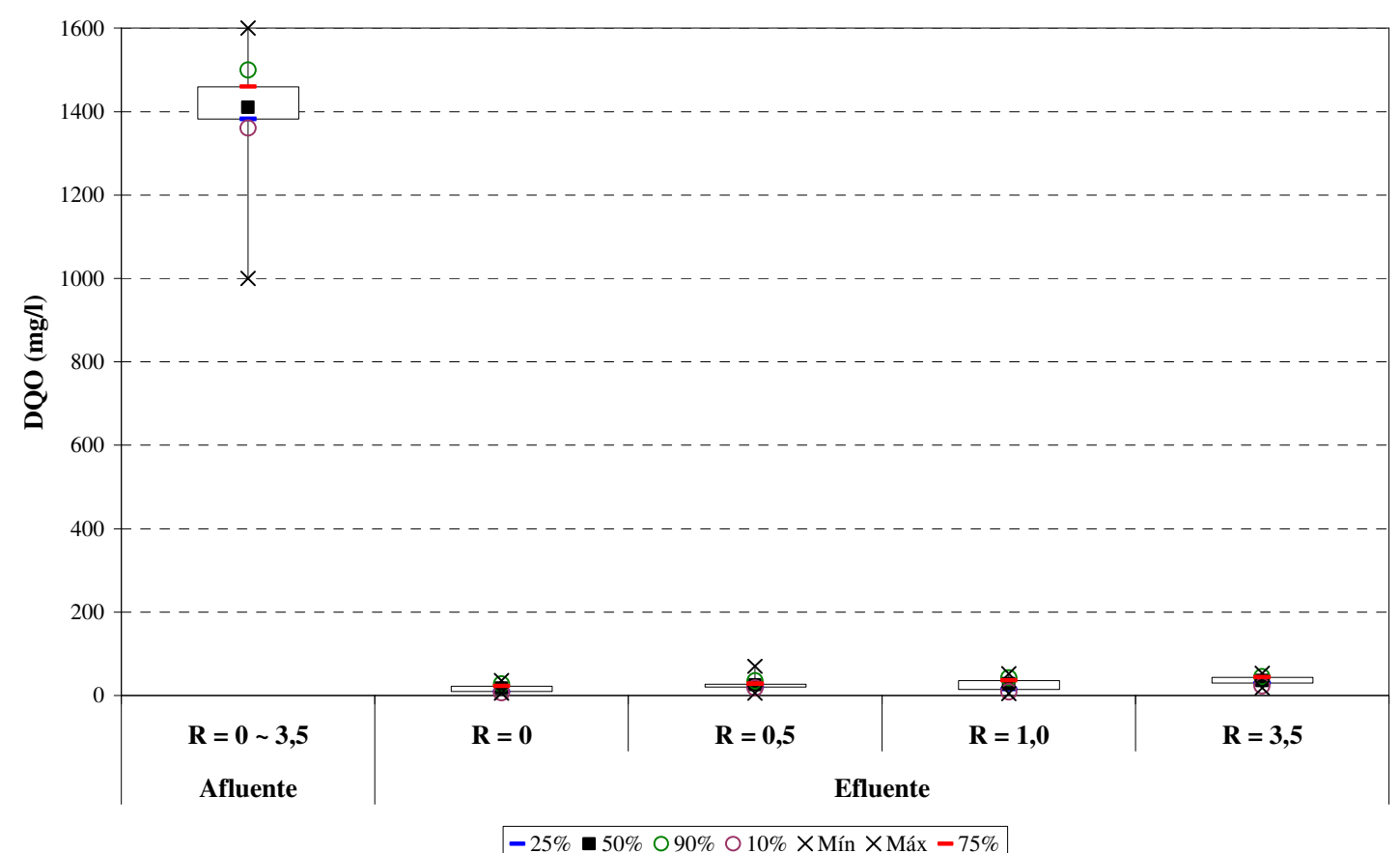

Figura 5.40 - Gráfico Box-plot de distribuição dos resultados de DQO afluente e efluente do reator combinado anaeróbio-aeróbio vertical de leito fixo para cada razão de recirculação (R) aplicada. 
Como pode ser visto na Figura 5.41, a concentração afluente de ácidos voláteis totais (AVT) teve grande variação ao longo da operação do reator, com valor médio de $405 \pm 136$ mg HAc/l, contudo, a concentração de AVT efluente se manteve praticamente constante e muito próxima da DQO efluente, com valor médio de $35 \pm 8$ mg HAc/l. Contudo, deve-se ressaltar que para baixas concentrações de AVT, o método analítico utilizado (DILALLO \& ALBERTSON, 1961) não possui boa precisão.

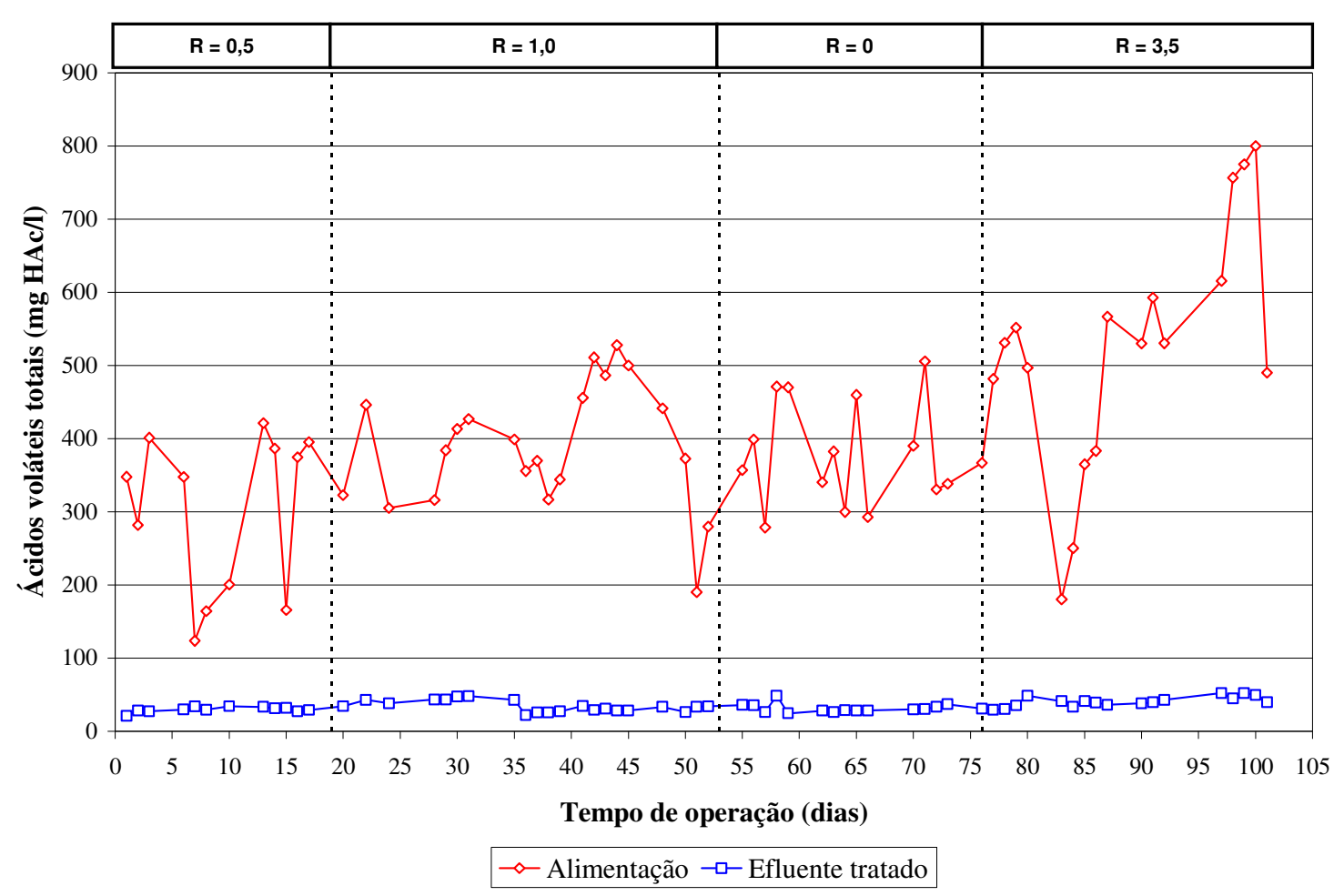

Figura 5.41 - Ácidos voláteis totais na alimentação e no efluente tratado do reator combinado anaeróbio-aeróbio vertical de leito fixo ao longo do tempo de operação, para cada razão de recirculação $(\mathrm{R})$ aplicada.

A atividade nitrificante permaneceu estável ao longo de toda a operação do reator combinado anaeróbio-aeróbio vertical de leito fixo, independente das vazões de recirculação aplicadas. Assim, embora as concentrações afluentes de nitrogênio total fossem relativamente altas, com valor médio de $158 \pm 21 \mathrm{mg} \mathrm{N} / 1$ (34\% de N-org e 66\% de $\mathrm{N}_{-} \mathrm{NH}_{4}{ }^{+}$), as concentrações efluentes de NTK permaneceram baixas por toda a operação, como observado na Figura 5.42, com valor médio de $10 \pm 4$ mg N/l. Para tanto, as concentrações de oxigênio dissolvido (OD) na zona aeróbia do reator foram mantidas relativamente altas (Figura 5.43), com valor médio de 5,8 $\pm 0,6 \mathrm{mg} \mathrm{O} / 1 . \mathrm{Na}$ Figura 5.44 é apresentado o gráfico Box-plot de distribuição dos resultados de NTK afluente e efluente para cada razão de recirculação (R) aplicada. 


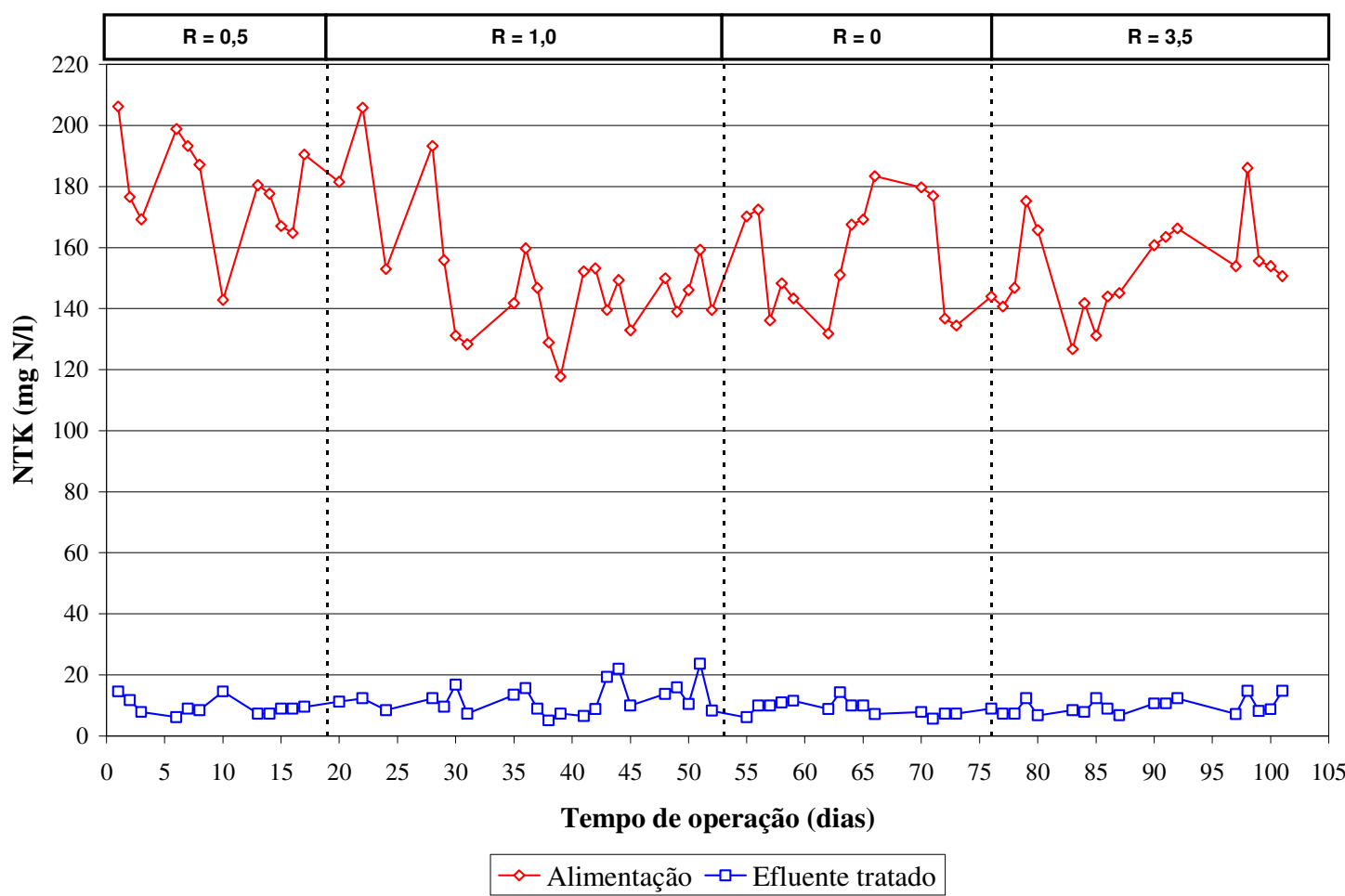

Figura 5.42 - NTK na alimentação e no efluente tratado do reator combinado anaeróbio-aeróbio vertical de leito fixo ao longo do tempo de operação, para cada razão de recirculação $(\mathrm{R})$ aplicada.

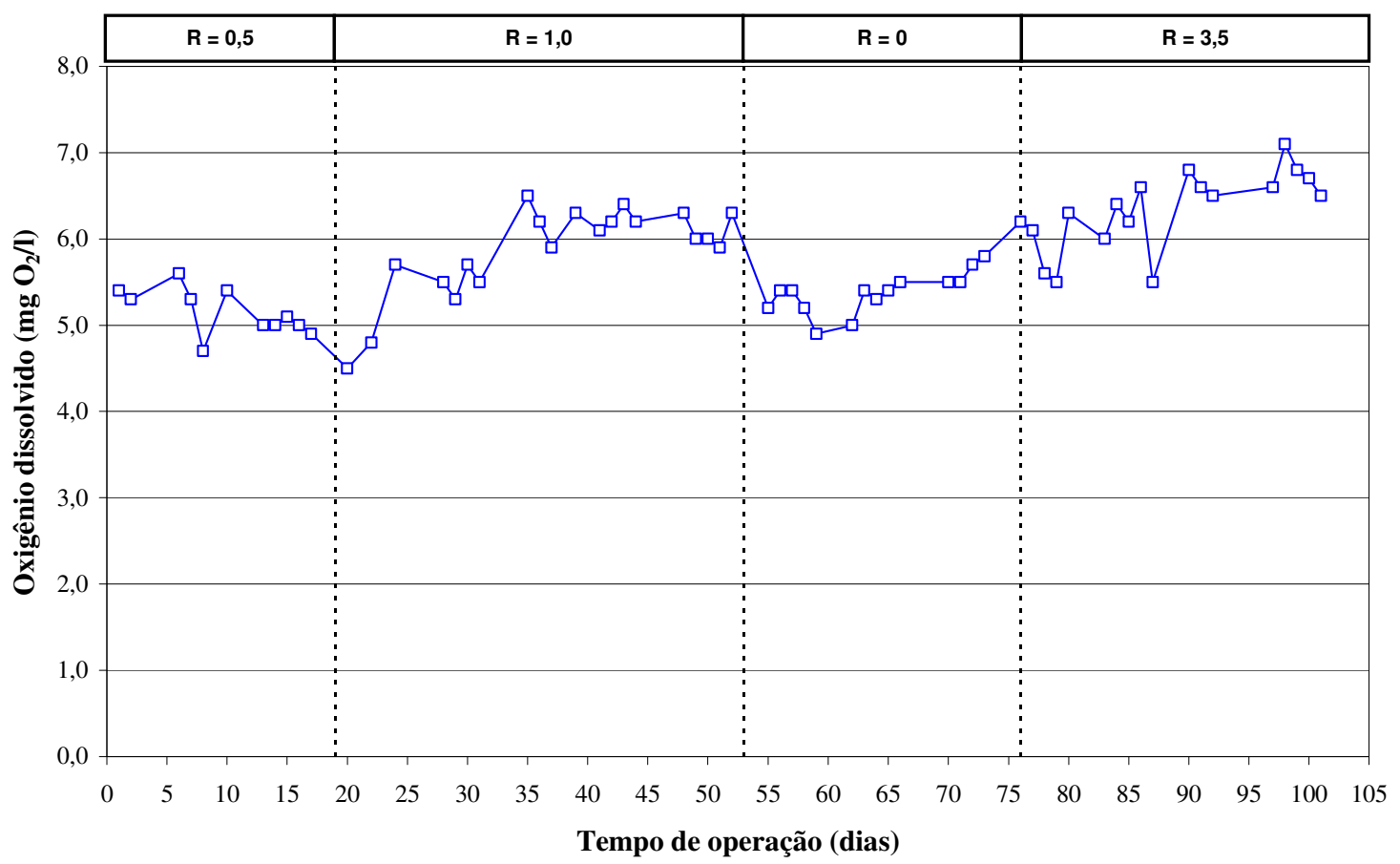

Figura 5.43 - Concentração de oxigênio dissolvido na zona aeróbia do reator combinado anaeróbio-aeróbio vertical de leito fixo ao longo do tempo de operação, para cada razão de recirculação $(\mathrm{R})$ aplicada. 


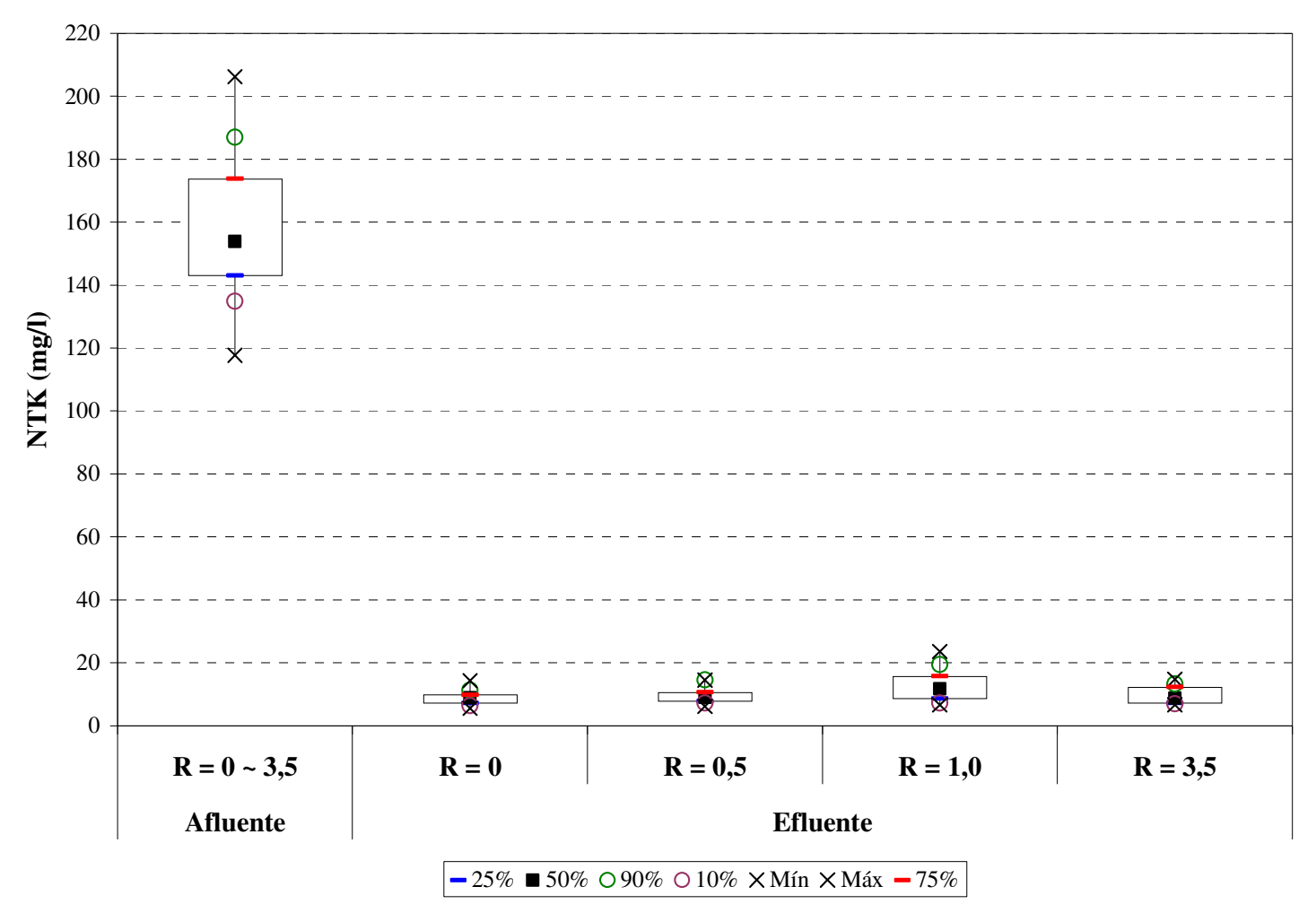

Figura 5.44 - Gráfico Box-plot de distribuição dos resultados de NTK afluente e efluente do reator combinado anaeróbio-aeróbio vertical de leito fixo para cada razão de recirculação $(\mathrm{R})$ aplicada.

Com a nitrificação estável, praticamente todo o nitrogênio efluente foi levado a $\mathrm{N}$-nitrato, fazendo com que as concentrações efluentes de $\mathrm{N}$-nitrito, $\mathrm{N}$-amoniacal e $\mathrm{N}$ org permanecessem baixas por toda a operação, apresentando valores médios de $1 \pm 1$ $\mathrm{mg} \mathrm{N}-\mathrm{NO}_{2}{ }^{-} / \mathrm{l}, 1 \pm 1 \mathrm{mg} \mathrm{N}-\mathrm{NH}_{4}{ }^{+} / \mathrm{l}$ e $9 \pm 4 \mathrm{mg} \mathrm{N}$-org/l, respectivamente.

Devido à desnitrificação promovida na zona anaeróbia do reator, as concentrações efluentes de $\mathrm{N}$-nitrato variaram de acordo com a vazão de recirculação

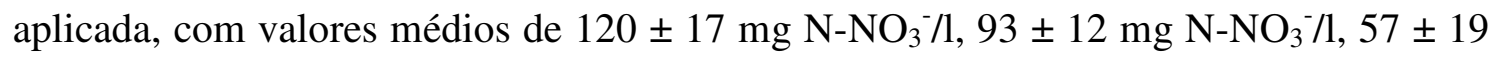
$\mathrm{mg} \mathrm{N}-\mathrm{NO}_{3}{ }^{-} / 1$ e $26 \pm 23 \mathrm{mg} \mathrm{N}-\mathrm{NO}_{3}{ }^{-} / 1$, respectivamente para $\mathrm{R}$ igual a $0,0,5,1$ e 3,5.

Na Figura 5.45 são apresentados os valores de N-nitrato, N-nitrito, $\mathrm{N}$-amoniacal e N-org no efluente tratado do reator combinado anaeróbio-aeróbio vertical de leito fixo ao longo do tempo de operação, para cada razão de recirculação aplicada. 


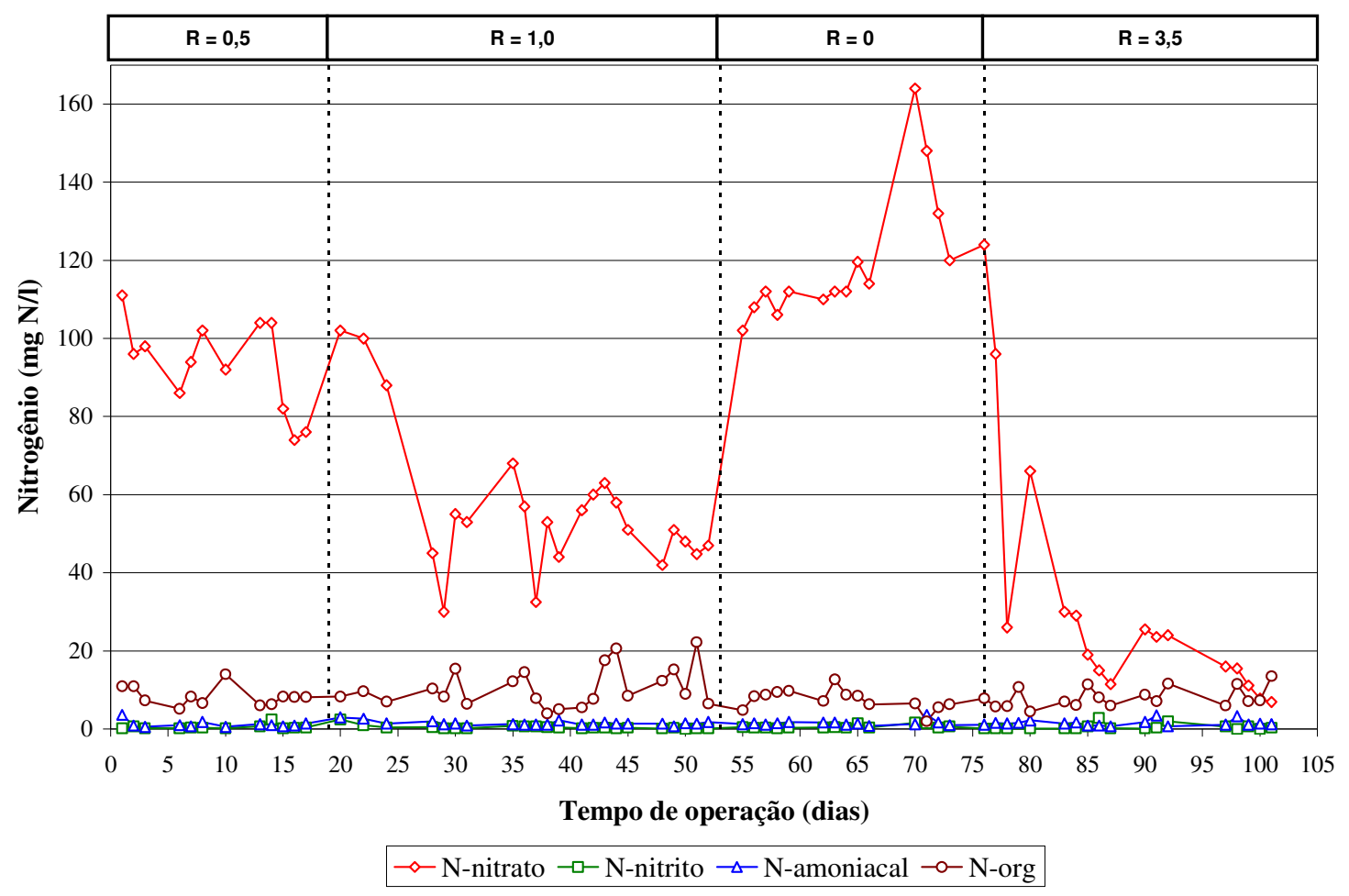

Figura 5.45 - Concentração de N-nitrato, N-nitrito, N-amoniacal e N-org no efluente tratado do reator combinado anaeróbio-aeróbio vertical de leito fixo ao longo do tempo de operação, para cada razão de recirculação $(\mathrm{R})$ aplicada.

A atividade desnitrificante foi evidenciada desde o início da operação através da diferença apresentada entre as concentrações de NT na alimentação e no efluente tratado do reator combinado anaeróbio-aeróbio vertical de leito fixo, como pode ser visto no gráfico da Figura 5.46. Como era esperado, com o aumento da recirculação interna de efluente tratado, aumentou-se a quantidade de N-nitrato reduzido a nitrogênio gasoso por meio da desnitrificação na zona anaeróbia do reator, com conseqüente queda na concentração efluente de NT. Assim, as concentrações médias de NT no efluente tratado para $\mathrm{R}$ igual a $0,0,5,1$ e 3,5 foram de $129 \pm 16 \mathrm{mg} \mathrm{N} / 1,103 \pm 13 \mathrm{mg} \mathrm{N} / 1,69 \pm 20 \mathrm{mg}$ $\mathrm{N} / \mathrm{l}$ e $35 \pm 22 \mathrm{mg} \mathrm{N} / \mathrm{l}$, respectivamente.

Na Figura 5.47 é apresentado o gráfico Box-plot de distribuição dos resultados de NT afluente e efluente para cada razão de recirculação (R) aplicada. 


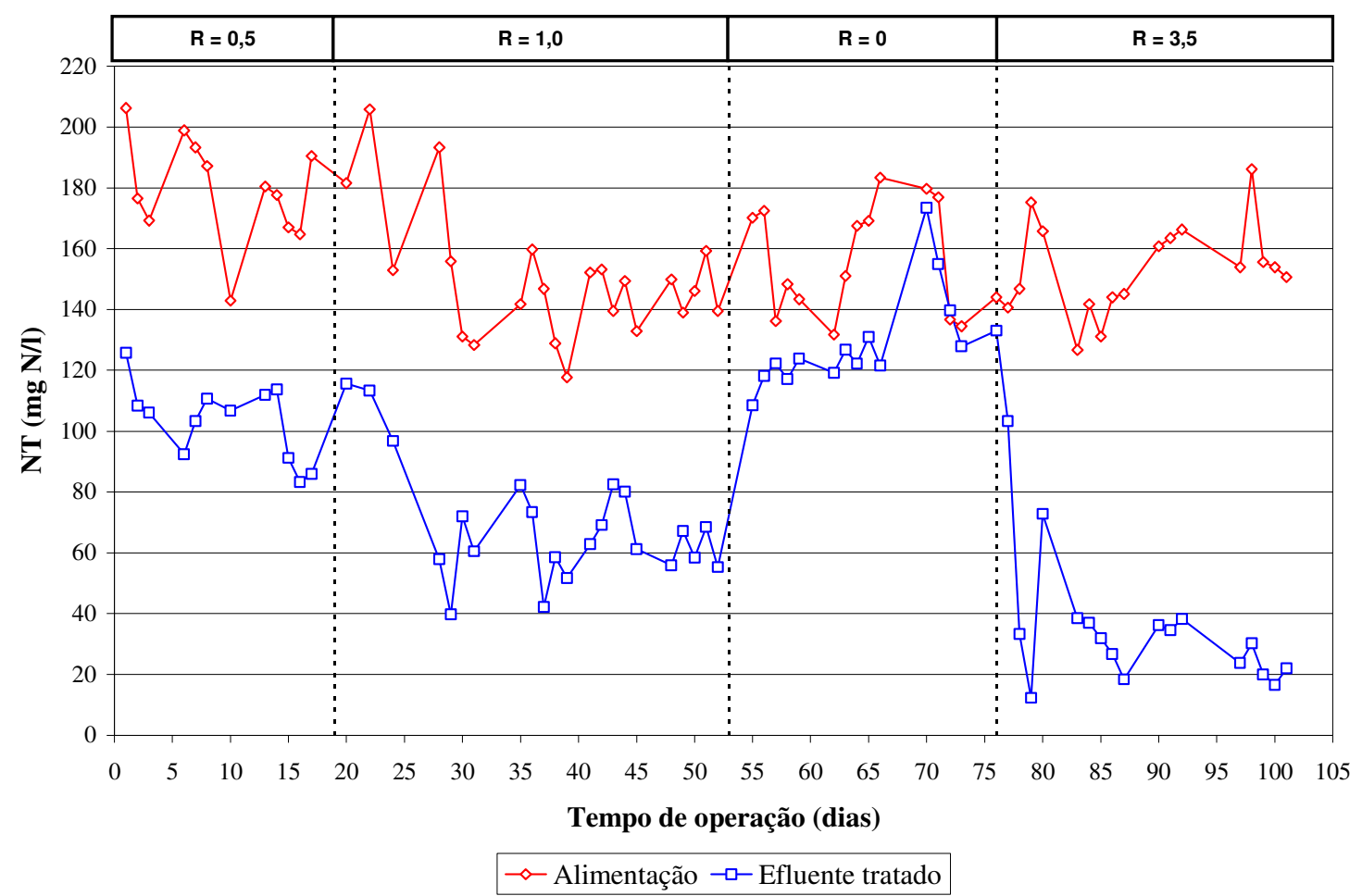

Figura 5.46 - Nitrogênio total (NT) na alimentação e no efluente tratado do reator combinado anaeróbio-aeróbio vertical de leito fixo ao longo do tempo de operação, para cada razão de recirculação $(\mathrm{R})$ aplicada.

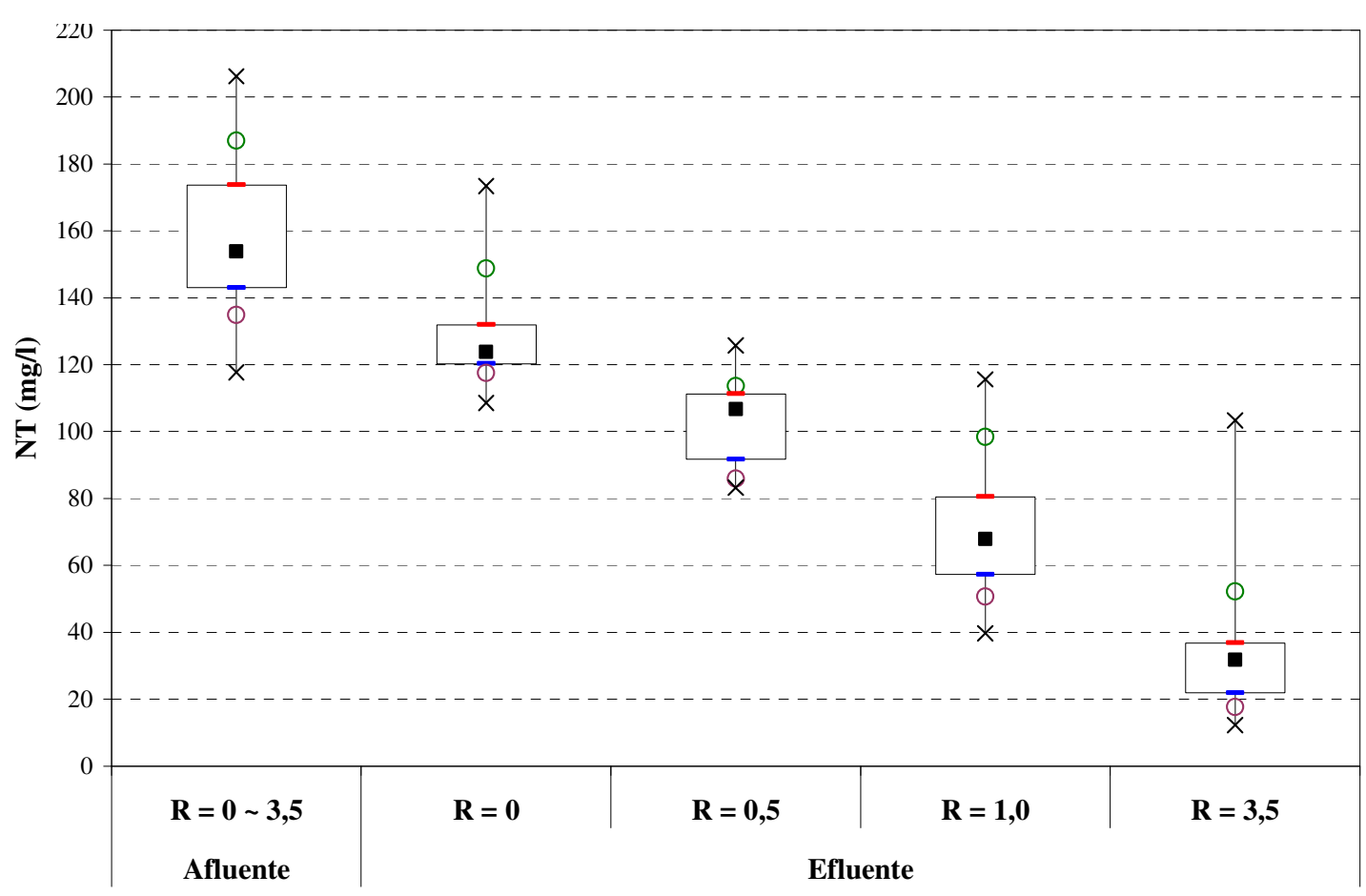

-25\% 50\% ○ 90\% ○ 10\% X Mín X Máx -75\%

Figura 5.47 - Gráfico Box-plot de distribuição dos resultados de nitrogênio total (NT) afluente e efluente do reator combinado anaeróbio-aeróbio vertical de leito fixo para cada razão de recirculação $(\mathrm{R})$ aplicada. 
Outro fator que evidenciou a atividade desnitrificante foi o aumento na alcalinidade a bicarbonato no efluente tratado conforme aumentou-se a vazão de recirculação, como pode ser visto na Figura 5.48. A alcalinidade a bicarbonato afluente apresentou valor médio de $601 \pm 112 \mathrm{mg} \mathrm{CaCO}_{3} / 1$ enquanto que no efluente tratado, para razões de recirculação iguais a $0,0,5,1$ e 3,5, as concentrações de alcalinidade a bicarbonato foram de $206 \pm 40 \mathrm{mg} \mathrm{CaCO} / 1,287 \pm 51 \mathrm{mg} \mathrm{CaCO}_{3} / 1,432 \pm 79 \mathrm{mg}$ $\mathrm{CaCO}_{3} / \mathrm{l}$ e $519 \pm 98 \mathrm{mg} \mathrm{CaCO}_{3} / \mathrm{l}$, respectivamente.

Analogamente, os valores de $\mathrm{pH}$ no efluente tratado também apresentaram tendência de crescimento com o aumento da vazão de recirculação, como observado na Figura 5.49, com valores médios de $8,1 \pm 0,2,8,2 \pm 0,2,8,4 \pm 0,1$ e $8,5 \pm 0,1$, respectivamente para $\mathrm{R}$ igual a $0,0,5,1$ e 3,5. O pH afluente manteve-se estável ao longo da operação, com valor médio de $8,0 \pm 0,2$.

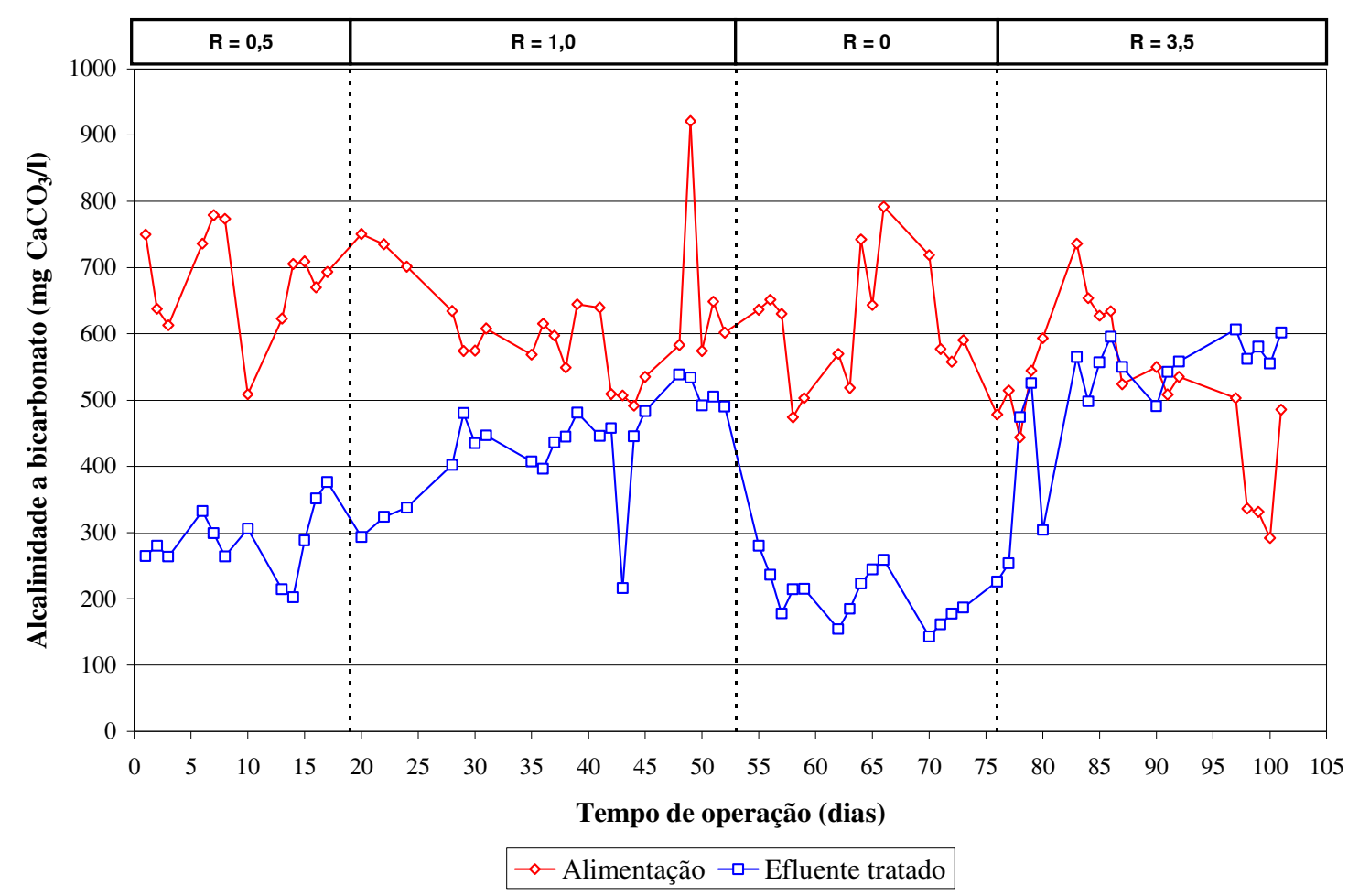

Figura 5.48 - Alcalinidade a bicarbonato na alimentação e no efluente tratado do reator combinado anaeróbio-aeróbio vertical de leito fixo ao longo do tempo de operação, para cada razão de recirculação $(\mathrm{R})$ aplicada. 


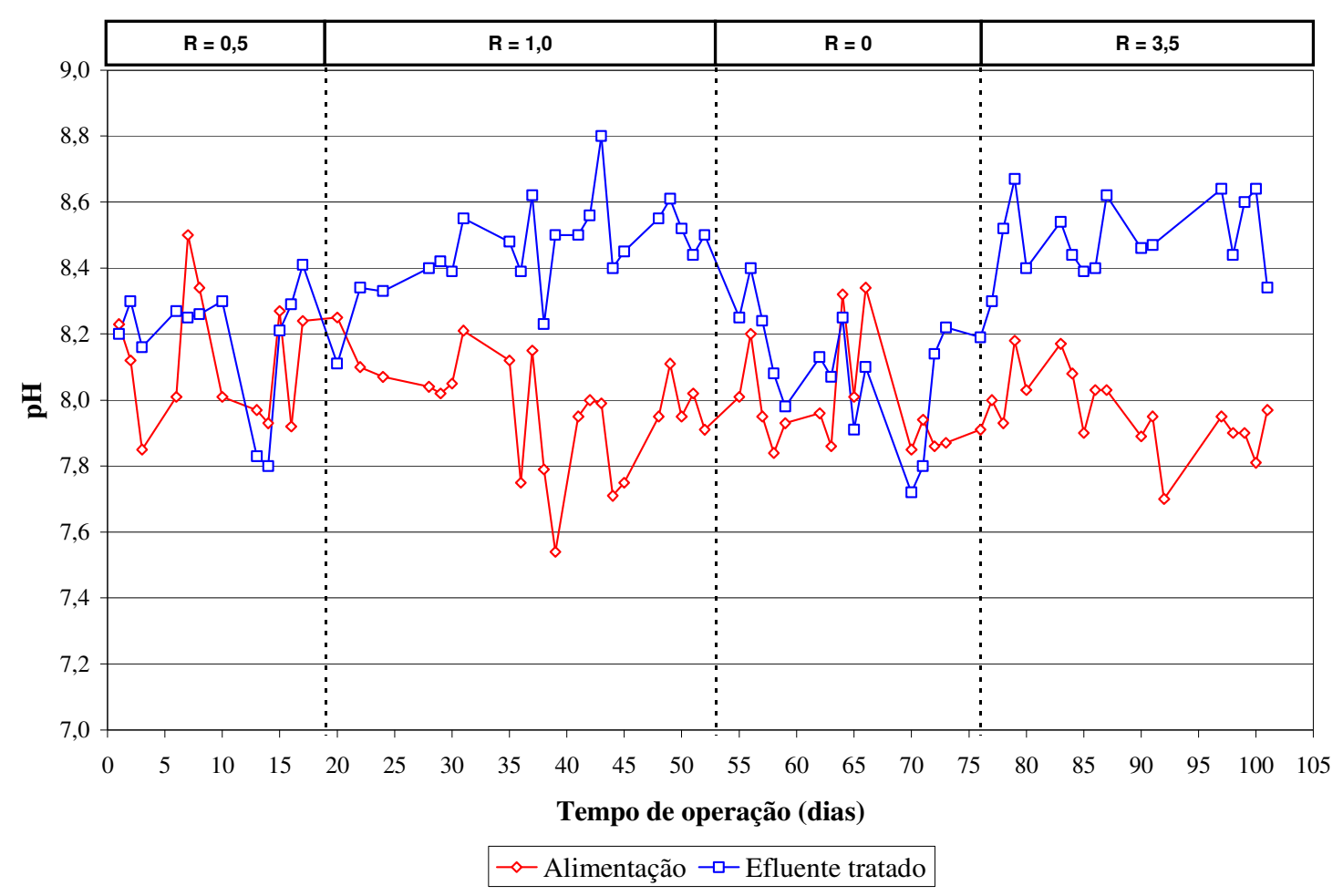

Figura 5.49 - pH na alimentação e no efluente tratado do reator combinado anaeróbioaeróbio vertical de leito fixo ao longo do tempo de operação, para cada razão de recirculação $(\mathrm{R})$ aplicada.

Conforme mostrado na Figura 5.37, entre os dias 54 e 76, apesar de não haver recirculação de efluente tratado para a zona anaeróbia do reator $(\mathrm{R}=0)$, o sistema apresentou remoção de nitrogênio média de $17 \pm 11 \%$. Isso significa que, parte do nitrogênio afluente (17\%) foi removido do sistema independentemente da recirculação interna aplicada, via assimilação celular ou nitrificação e desnitrificação simultâneas na zona aeróbia do reator.

Para os metabolismos anaeróbio e aeróbio, os requisitos nutricionais comumente citados na literatura para a síntese celular apresentam relações DBO:N:P iguais a 500:5:1 e 100:5:1, respectivamente. Assim, para a condição operacional do reator combinado anaeróbio-aeróbio vertical de leito fixo em que $70 \%$ da DQO afluente era removida na zona anaeróbia (1000 mg DQO/1) e 30\% era oxidada na zona aeróbia do reator (400 mg DQO/l) e que a relação DQO:DBO afluente era igual a igual a 1,5:1, a concentração calculada de nitrogênio assimilada na síntese celular foi de $20 \mathrm{mg} \mathrm{N} / \mathrm{l}$, equivalendo a $13 \%$ do nitrogênio afluente $(150 \mathrm{mg} \mathrm{N} / \mathrm{l})$, sendo este valor muito próximo do valor observado empiricamente $(17 \pm 11 \%)$. Portanto, pode-se considerar que $17 \%$ 
do nitrogênio afluente ao reator foi assimilado na síntese celular.

Logo, para o cálculo da quantidade de N-nitrato (ou N-nitrito) formado no sistema $\left(\mathrm{N}_{\text {nitr }}\right)$ desconsiderou-se a fração de nitrogênio assimilada (17\%), como apresentado na equação abaixo:

$$
\mathrm{N}_{\text {nitr }}=\left(N T K_{\text {affuente }}-N T K_{\text {efluente }}\right) \cdot 0,83
$$

Assim, a eficiência de desnitrificação via recirculação interna de efluente tratado $\left(\mathrm{E}_{\mathrm{DN}}\right)$ foi calculada conforme a seguinte equação:

$$
E_{D N}=\frac{\mathrm{N}_{n i t r}-\mathrm{N}_{\mathrm{e}}}{\mathrm{N}_{\text {nitr }}}
$$

$\mathrm{Na}$ equação 5.4, $\mathrm{N}_{\text {nitr }}$ é a concentração de nitrogênio nitrificado e $\mathrm{N}_{\mathrm{e}}$ é a somatória das concentrações de $\mathrm{N}$-nitrito e $\mathrm{N}$-nitrato no efluente tratado do sistema. $\mathrm{Na}$ Tabela 5.8 são apresentados os resultados experimentais de $\mathrm{N}_{\text {nitr }}, \mathrm{N}_{\mathrm{e}}$ e $\mathrm{E}_{\mathrm{DN}}$ obtidos para cada razão de recirculação interna aplicada $(\mathrm{R})$.

Tabela 5.8 - Quantidade de nitrogênio nitrificado $\left(\mathrm{N}_{\text {nitr }}\right)$, concentração efluente de nitrogênio na forma de nitrito e nitrato $\left(\mathrm{N}_{\mathrm{e}}\right)$ e eficiência de desnitrificação $\left(\mathrm{E}_{\mathrm{DN}}\right)$ em função da razão de recirculação interna aplicada (R).

\begin{tabular}{ccccc}
\hline Parâmetros & $\mathbf{R}=\mathbf{0}$ & $\mathbf{R}=\mathbf{0 , 5}$ & $\mathbf{R}=\mathbf{1 , 0}$ & $\mathbf{R}=\mathbf{3 , 5}$ \\
\hline $\mathrm{N}_{\text {nitr }}(\mathrm{mg} \mathrm{N} / \mathrm{l})$ & $122 \pm 16$ & $141 \pm 15$ & $115 \pm 17$ & $119 \pm 12$ \\
$\mathrm{~N}_{\mathrm{e}}(\mathrm{mg} \mathrm{N} / \mathrm{l})$ & $120 \pm 17$ & $94 \pm 12$ & $57 \pm 19$ & $25 \pm 23$ \\
$\mathrm{E}_{\mathrm{DN}}(\%)$ & $1 \pm 15$ & $33 \pm 10$ & $50 \pm 13$ & $78 \pm 20$ \\
\hline
\end{tabular}

Para a modelação matemática da desnitrificação através da recirculação interna de efluente tratado, considerou-se que todo o $\mathrm{N}$-nitrato ou $\mathrm{N}$-nitrito que passasse pela zona anaeróbia do reator (via recirculação) era desnitrificado. Assim, fez-se o seguinte balanço de massa para o N-nitrato (ou N-nitrito) no sistema: 


$$
\begin{aligned}
& \overbrace{\left.\begin{array}{c}
\text { nitrato } \\
\text { produzido } \text { na } \\
\text { zona aeróbia }
\end{array}\right)}^{\text {nitrato entrada }}=\overbrace{\left(\begin{array}{c}
\text { nitrato } \\
\text { presente } \text { no } \\
\text { efluente tratado }
\end{array}\right)}^{\text {nitrato saída }}+\overbrace{\left(\begin{array}{c}
\text { nitrato } \\
\text { presente } \text { na } \\
\text { recirculação interna }
\end{array}\right)}^{\text {nitrato removido }} \\
& \text { Q.N } \mathrm{N}_{\text {nitr }}=N_{e} \cdot(Q+R \cdot Q) \\
& \frac{\mathrm{N}_{\text {nitr }}-\mathrm{N}_{\mathrm{e}}}{\mathrm{N}_{\text {nitr }}}=\frac{R}{1+R}
\end{aligned}
$$

Sabendo que $\left(\mathrm{N}_{\text {nitr }}-\mathrm{N}_{\mathrm{e}}\right) / \mathrm{N}_{\text {nitr }}$ representa a eficiência de desnitrificação do sistema $\left(\mathrm{E}_{\mathrm{DN}}\right)$, a equação 5.6 pode ser escrita com:

$$
E_{D N}=\frac{R}{1+R}
$$

Como pode ser notado na Figura 5.50, os valores de eficiência de desnitrificação $\left(\mathrm{E}_{\mathrm{DN}}\right)$ experimentais, obtidos na operação do reator variando-se a razão de recirculação (Tabela 5.8), possuem grande correlação com os valores teóricos obtidos através da Equação $5.7\left(R^{2}=0,99\right)$. Portanto, pode-se concluir que o sistema obteve as eficiências máximas de desnitrificação previstas para cada vazão de recirculação aplicada.

Os valores médios da carga orgânica volumétrica $(\mathrm{COV})$ e da carga volumétrica de nitrogênio (CVN) aplicadas ao reator combinado anaeróbio-aeróbio vertical de leito fixo foram de $0,97 \pm 0,05 \mathrm{~kg}$ DQO. $\mathrm{m}^{-3} \cdot \mathrm{d}^{-1}$ e $0,11 \pm 0,01 \mathrm{~kg} \mathrm{~N} \cdot \mathrm{m}^{-3} \cdot \mathrm{d}^{-1}$, respectivamente, considerando volume útil total do reator igual a 28,3 1 (17 1 da zona anaeróbia e 11,3 1 da zona aeróbia).

Na Figura 5.51 são apresentados os valores de carga orgânica volumétrica $(\mathrm{COV})$ e carga volumétrica de nitrogênio $(\mathrm{CVN})$ aplicados ao longo da operação do reator combinado anaeróbio-aeróbio vertical de leito fixo com recirculação interna de efluente tratado. 


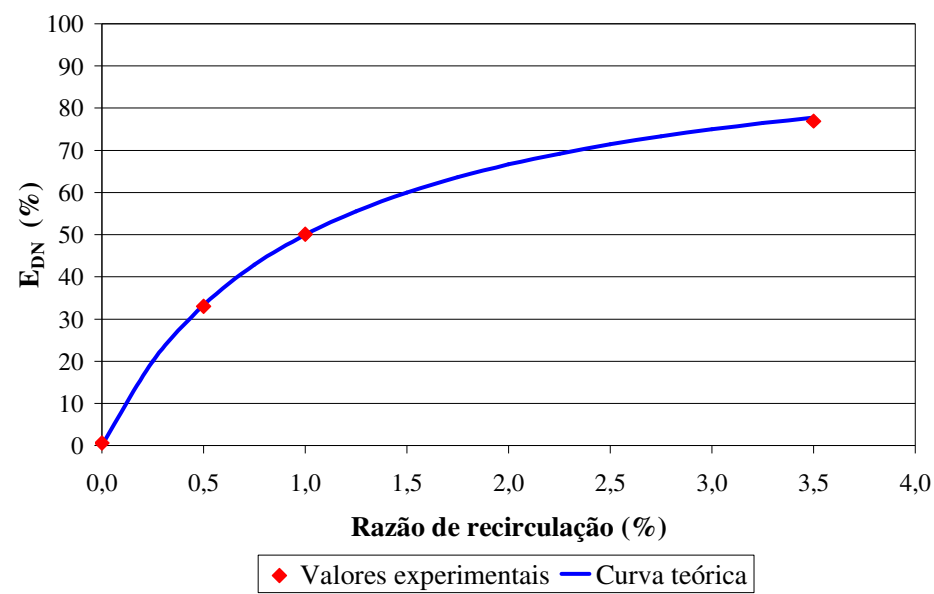

Figura 5.50 - Eficiências de desnitrificação $\left(E_{D N}\right)$ empíricas e teóricas em função da razão de recirculação interna aplicada $(\mathrm{R})$.

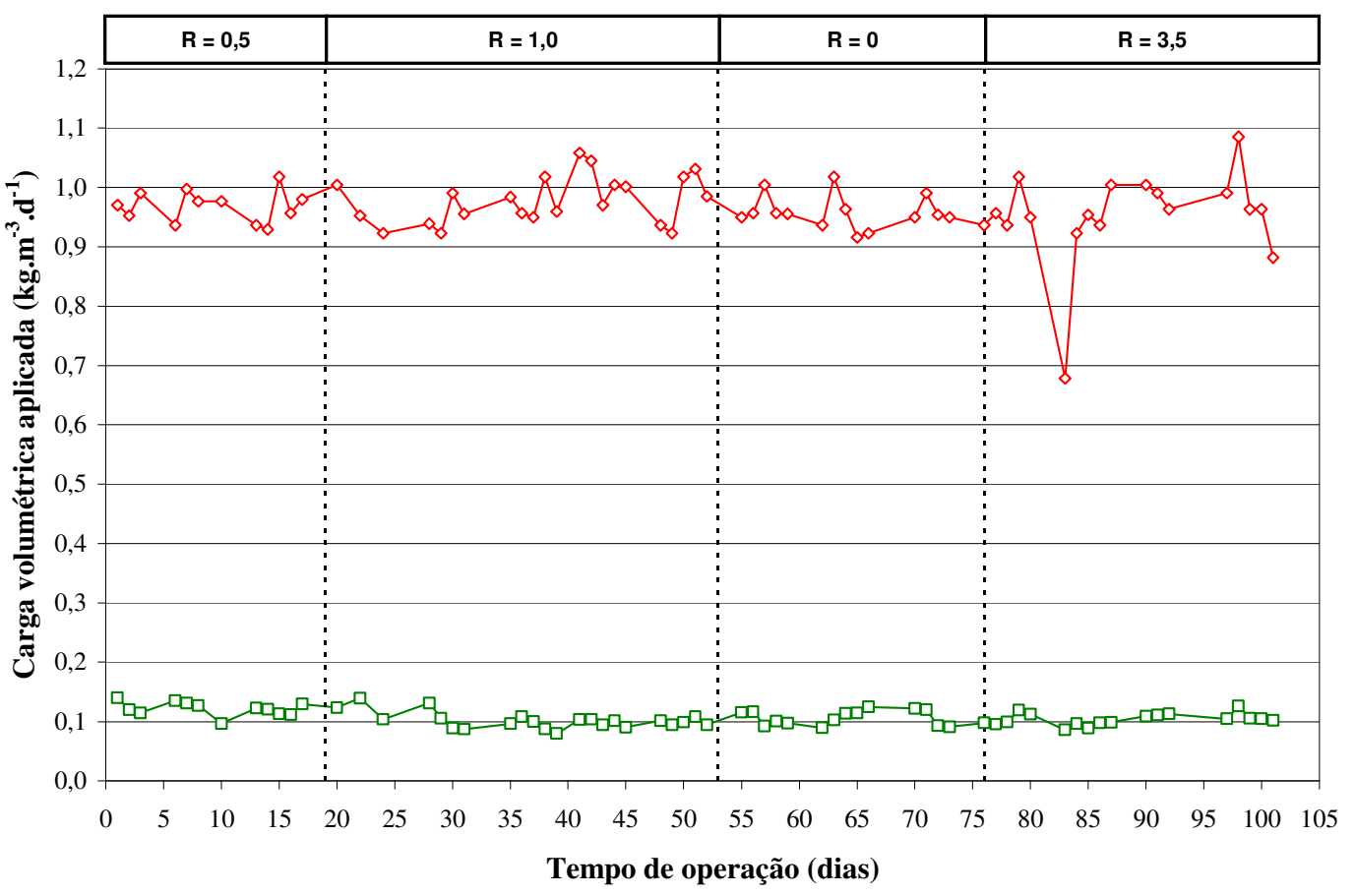

$$
\rightarrow-\mathrm{COV}-\mathrm{-}-\mathrm{CVN}
$$

Figura 5.51 - Carga orgânica volumétrica $(\mathrm{COV})$ e carga volumétrica de nitrogênio $(\mathrm{CVN})$ aplicadas ao longo da operação do reator combinado anaeróbio-aeróbio vertical de leito fixo com recirculação interna de efluente tratado. 
Comparado com outros sistemas de tratamento de águas residuárias industriais para a remoção de matéria orgânica e nitrogênio citados na literatura (Tabela 5.9), o reator combinado anaeróbio-aeróbio vertical de leito fixo com recirculação de efluente tratado apresentou desempenho muito bom no tratamento da água residuária da Ajinomoto, obtendo eficiências médias na remoção de DQO, NTK e NT de $97 \pm 1 \%, 94$ $\pm 2 \%$ e $77 \pm 16 \%$, respectivamente, para $\mathrm{R}$ igual a 3,5 e $\mathrm{TDH}$ de $35 \mathrm{~h}$ baseado no volume útil do reator $(28,31)$.

Para efeito ilustrativo, na Figura 5.52 são apresentadas as fotos do afluente e efluente do reator combinado anaeróbio-aeróbio vertical de leito fixo com recirculação interna de efluente tratado.

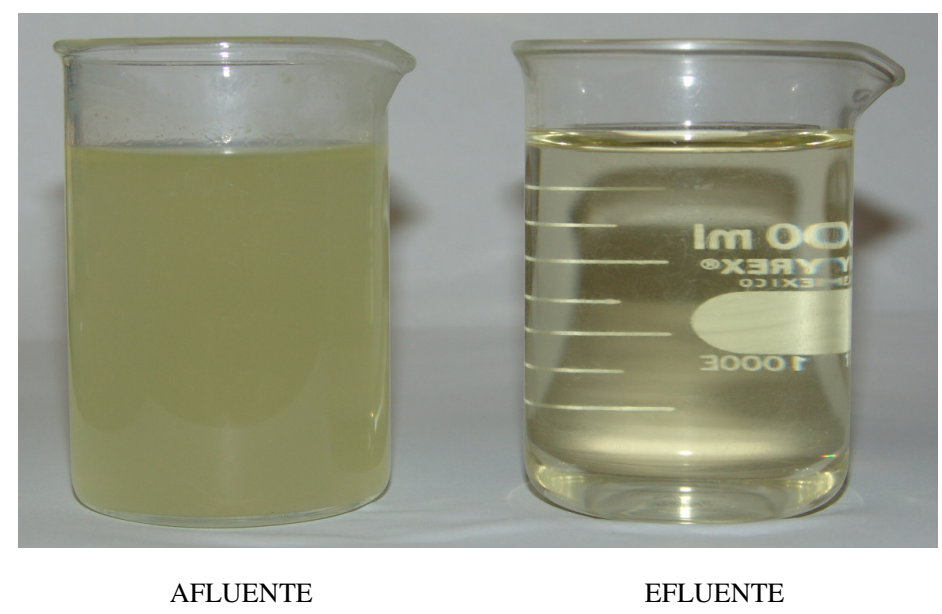

Figura 5.52 - Fotos do afluente e efluente do reator combinado anaeróbio-aeróbio vertical de leito fixo com recirculação interna de efluente tratado.

Os resultados médios de todos os parâmetros analisados durante a operação do reator combinado anaeróbio-aeróbio vertical de leito fixo são apresentados na Tabela 5.10 . 
Reator combinado anaeróbio-aeróbio de leito fixo para remoção de matéria orgânica e nitrogênio de água residuária de indústria produtora de lisina

Tabela 5.9 - Comparação entre o reator combinado anaeróbio-aeróbio vertical de leito fixo com recirculação inferna de efluente e alguns sistemas de tratamento de águas residuárias industriais citados na literatura.

\begin{tabular}{|c|c|c|c|c|c|c|c|c|}
\hline \multirow[b]{2}{*}{ Tipo de sistema de tratamento } & \multicolumn{3}{|c|}{ Características da água residuária } & \multirow{2}{*}{$\begin{array}{c}\text { TDH do } \\
\text { sistema } \\
\text { (d) }\end{array}$} & \multicolumn{3}{|c|}{ Eficiências de remoção } & \multirow{2}{*}{$\begin{array}{c}\text { Referências } \\
\text { bibliográficas }\end{array}$} \\
\hline & $\begin{array}{l}\text { Tipo de } \\
\text { indústria }\end{array}$ & $\begin{array}{l}\text { DQO } \\
(\mathrm{mg} / \mathrm{l})\end{array}$ & $\begin{array}{l}\text { NTK } \\
(\mathrm{mg} / \mathrm{l})\end{array}$ & & $\begin{array}{c}\text { DQO } \\
(\%)\end{array}$ & $\begin{array}{c}\text { NTK } \\
(\%)\end{array}$ & $\begin{array}{l}\text { NT } \\
(\%)\end{array}$ & \\
\hline $\mathrm{MBR}^{\mathrm{b}}$ com reator pré-anóxico & $\mathrm{EPTO}^{\mathrm{a}}$ & 1000 & 175 & 1,7 & 94 & 90 & 75 & Chen et al. (2003b) \\
\hline $\mathrm{SBR}^{\mathrm{c}}$ & Alimentícia & 1500 & 630 & 1,7 & 90 & 98 & 79 & Villaverde et al. (2000) \\
\hline Bardenpho $^{\mathrm{f}}$ & Alimentícia & 2000 & 250 & 3,1 & 97 & 94 & 87 & Ajinomoto (2006) \\
\hline Reator combinado anaeróbio-aeróbio & Alimentícia & 1400 & 160 & 1,5 & 97 & 94 & 77 & Objeto do estudo \\
\hline
\end{tabular}

${ }^{\text {a }}$ EPTO: electronics and photonics technology office

${ }^{\mathrm{b}}$ MBR: membrane bioreactor

${ }^{\mathrm{c}} \mathrm{SBR}$ : sequencing batch reactor

${ }^{\mathrm{d}}$ UASB: upflow anaerobic sludge blanket

${ }^{\mathrm{e}}$ UBAF: upflow biological aerated filter

${ }^{\mathrm{f}}$ Bardenpho: sistema de lodos ativados com reatores pré e pós anóxicos (Figura 3.2c) 
Tabela 5.10 - Resultados médios dos parâmetros analisados durante a operação do reator combinado anaeróbio-aeróbio vertical de leito fixo com recirculação de efluente tratado.

\begin{tabular}{|c|c|c|c|c|c|c|c|c|}
\hline \multirow{2}{*}{$\begin{array}{c}\text { Período operacional e } \\
\text { razão de recirculação }\end{array}$} & \multicolumn{2}{|c|}{$\begin{array}{c}1^{\circ} \text { ao } 19^{\circ} \text { dia } \\
R=50 \%\end{array}$} & \multicolumn{2}{|c|}{$\begin{array}{c}20^{\circ} \text { ao } 53^{\circ} \text { dia } \\
R=100 \%\end{array}$} & \multicolumn{2}{|c|}{$\begin{array}{c}54^{\circ} \text { ao } 76^{\circ} \text { dia } \\
R=0 \%\end{array}$} & \multicolumn{2}{|c|}{$\begin{array}{c}{77^{\circ}}^{\text {ao } 101^{\circ} \text { dia }} \\
\mathrm{R}=350 \%\end{array}$} \\
\hline & Afluente & Efluente & Afluente & Efluente & Afluente & Efluente & Afluente & Efluente \\
\hline Temperatura $\left({ }^{\circ} \mathrm{C}\right)$ & $25,1 \pm 0,9$ & $30,5 \pm 0,7$ & $24,3 \pm 1,1$ & $29,6 \pm 0,6$ & $24,2 \pm 1,1$ & $29,6 \pm 0,8$ & $24,7 \pm 0,9$ & $30,0 \pm 0,6$ \\
\hline $\mathrm{pH}$ & $8,1 \pm 0,2$ & $8,2 \pm 0,2$ & $8,0 \pm 0,2$ & $8,5 \pm 0,1$ & $8,0 \pm 0,2$ & $8,1 \pm 0,2$ & $8,0 \pm 0,1$ & $8,5 \pm 0,1$ \\
\hline $\mathrm{OD}^{\mathrm{a}}\left(\mathrm{mg} \mathrm{O}_{2} / \mathrm{l}\right)$ & $0,2 \pm 0,1$ & $5,2 \pm 0,3$ & $0,1 \pm 0,1$ & $5,9 \pm 0,5$ & $0,0 \pm 0,1$ & $5,4 \pm 0,3$ & $0,1 \pm 0,1$ & $6,3 \pm 0,5$ \\
\hline $\mathrm{AB}^{\mathrm{b}}\left(\mathrm{mg} \mathrm{CaCO}_{3} / \mathrm{l}\right)$ & $683 \pm 78$ & $287 \pm 51$ & $617 \pm 96$ & $432 \pm 79$ & $606 \pm 95$ & $206 \pm 40$ & $518 \pm 119$ & $519 \pm 98$ \\
\hline DQO bruta $\left(\mathrm{mg} \mathrm{O}_{2} / \mathrm{l}\right)$ & $1427 \pm 40$ & $26 \pm 16$ & $1442 \pm 60$ & $26 \pm 13$ & $1411 \pm 41$ & $17 \pm 9$ & $1404 \pm 123$ & $36 \pm 10$ \\
\hline DQO filtrada $\left(\mathrm{mg} \mathrm{O}_{2} / \mathrm{l}\right)$ & $1074 \pm 81$ & $21 \pm 11$ & $1122 \pm 123$ & $21 \pm 12$ & $1098 \pm 76$ & $12 \pm 9$ & $1146 \pm 145$ & $30 \pm 12$ \\
\hline $\mathrm{AVT}^{\mathrm{c}}$ (mg HAc/l) & $301 \pm 108$ & $30 \pm 4$ & $389 \pm 85$ & $34 \pm 8$ & $379 \pm 71$ & $32 \pm 6$ & $523 \pm 168$ & $41 \pm 7$ \\
\hline NTK (mg N/l) & $180 \pm 17$ & $10 \pm 3$ & $150 \pm 21$ & $12 \pm 5$ & $156 \pm 18$ & $9 \pm 2$ & $153 \pm 15$ & $10 \pm 3$ \\
\hline $\mathrm{N}-\mathrm{NH}_{4}{ }^{+}(\mathrm{mg} \mathrm{N} / \mathrm{l})$ & $109 \pm 31$ & $1 \pm 1$ & $94 \pm 26$ & $1 \pm 1$ & $112 \pm 17$ & $1 \pm 1$ & $110 \pm 24$ & $2 \pm 1$ \\
\hline N-org (mg N/l) & $71 \pm 28$ & $8 \pm 3$ & $56 \pm 18$ & $11 \pm 5$ & $45 \pm 13$ & $8 \pm 2$ & $44 \pm 16$ & $8 \pm 3$ \\
\hline $\mathrm{N}-\mathrm{NO}_{2}^{-}(\mathrm{mg} \mathrm{N} / \mathrm{l})$ & - & $1 \pm 1$ & - & $0 \pm 1$ & - & $1 \pm 0$ & - & $1 \pm 1$ \\
\hline $\mathrm{N}-\mathrm{NO}_{3}{ }^{-}(\mathrm{mg} \mathrm{N} / \mathrm{l})$ & - & $93 \pm 12$ & - & $57 \pm 19$ & - & $120 \pm 17$ & - & $26 \pm 23$ \\
\hline $\mathrm{ST}(\mathrm{mg} / \mathrm{l})$ & $1539 \pm 187$ & $1056 \pm 68$ & $1411 \pm 94$ & $994 \pm 72$ & $1251 \pm 337$ & $992 \pm 323$ & $1460 \pm 84$ & $983 \pm 100$ \\
\hline $\mathrm{SST}(\mathrm{mg} / \mathrm{l})$ & $240 \pm 59$ & $8 \pm 3$ & $178 \pm 52$ & $11 \pm 4$ & $161 \pm 47$ & $9 \pm 5$ & $142 \pm 51$ & $15 \pm 8$ \\
\hline $\mathrm{SSV}(\mathrm{mg} / \mathrm{l})$ & $227 \pm 52$ & $6 \pm 3$ & $160 \pm 45$ & $7 \pm 3$ & $150 \pm 44$ & $7 \pm 4$ & $130 \pm 47$ & $12 \pm 7$ \\
\hline
\end{tabular}

${ }^{a}$ OD: Oxigênio dissolvido; ${ }^{b}$ AB: Alcalinidade a bicarbonato; ${ }^{\mathrm{c}}$ AVT: Ácidos voláteis totais 


\subsection{EXAMES MICROBIOLÓGICOS}

Após o término da fase experimental, o reator combinado anaeróbio-aeróbio vertical de leito fixo foi desmontado, retirando-se amostras ao longo do reator para a quantificação da biomassa aderida nos suportes e a realização de exames microbiológicos.

Os pontos de amostragem, conforme apresentado em Material e Métodos (Figura 4.4) foram os seguintes:

$1-1^{\mathrm{o}}$ módulo anaeróbio com suporte de argila expandida;

$2-2^{\circ}$ módulo anaeróbio com suporte de espuma de poliuretano;

$3-3^{\circ}$ módulo anaeróbio com suporte de espuma de poliuretano;

4 - Interface entre as zonas anaeróbia e aeróbia (câmara de aeração);

$5-1^{\mathrm{o}}$ módulo aeróbio com suporte de espuma de poliuretano;

$6-2^{\circ}$ módulo aeróbio com suporte de espuma de poliuretano.

Na Figura 5.53 são apresentadas fotos das amostras de suporte coletadas nas zonas anaeróbia e aeróbia do reator combinado anaeróbio-aeróbio vertical de leito fixo. 


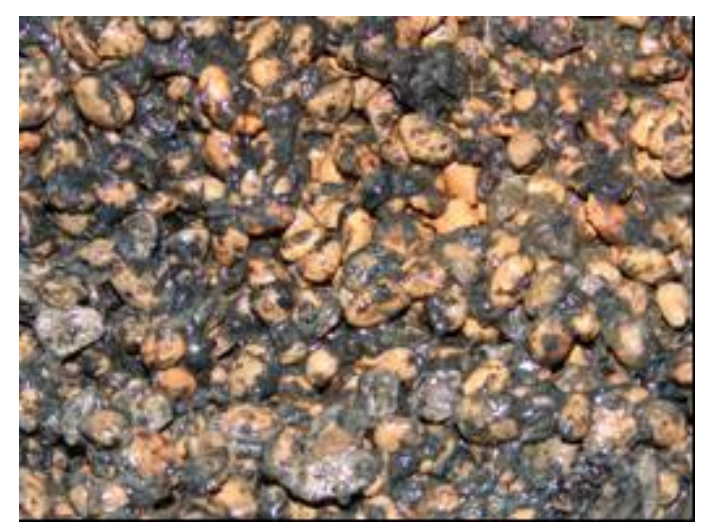

(a) Biomassa aderida no suporte de argila expandida da zona anaeróbia (ponto de amostragem 1)

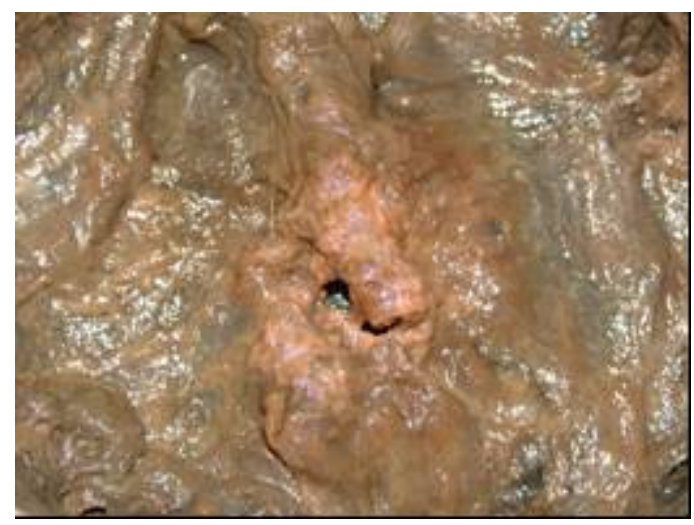

(c) Biomassa em suspensão presente na interface entre as zonas anaeróbia e aeróbia (ponto de amostragem 4)

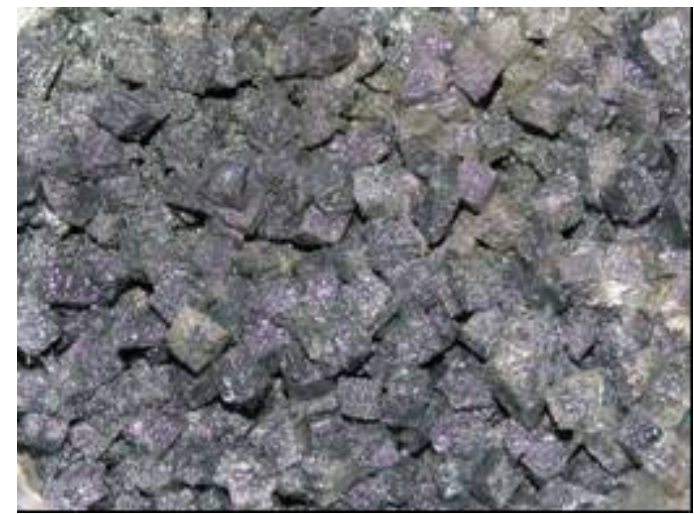

(b) Biomassa aderida no suporte de espuma de poliuretano da zona anaeróbia (pontos de amostragem 2 e 3 )

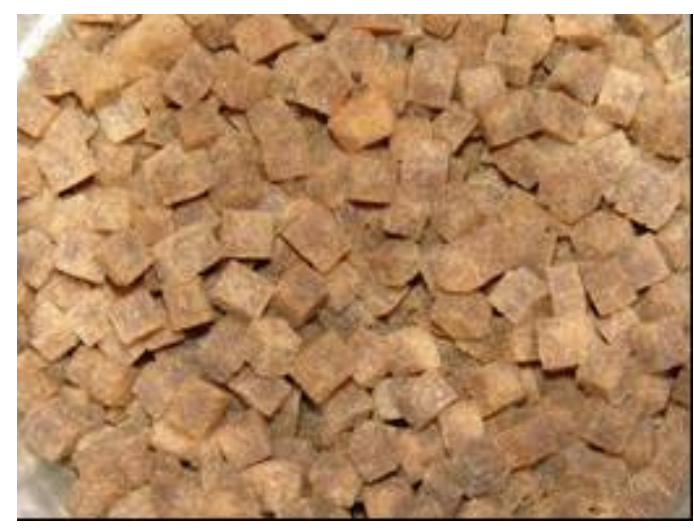

(d) Biomassa aderida no suporte de espuma de poliuretano da zona aeróbia (pontos de amostragem 5 e 6 )

Figura 5.53 - Fotos das amostras de biomassa (suspensa e aderida nos suportes) coletadas ao longo do reator combinado anaeróbio-aeróbio vertical de leito fixo.

\subsubsection{Quantificação da biomassa aderida nos suportes}

Conforme apresentado Tabela 5.11, os suportes de matrizes cúbicas de espuma de poliuretano apresentaram alta retenção de biomassa por massa de suporte, com valores médios nas zonas anaeróbia e aeróbia do reator de 0,87 $\pm 0,06 \mathrm{~g} \mathrm{SVT} / \mathrm{g}_{\text {suporte }} \mathrm{e}$ $0,38 \pm 0,13 \mathrm{~g} \mathrm{SVT} / \mathrm{g}_{\text {suporte}}$, respectivamente. Os suportes de argila expandida apresentaram menor retenção celular por massa de suporte, com valor de 0,01 g $\mathrm{SVT} / \mathrm{g}_{\text {suporte }}$ 
Tabela 5.11 - Sólidos totais (ST) e sólidos voláteis totais (SVT) aderidos por massa de suporte.

\begin{tabular}{ccc}
\hline $\begin{array}{c}\text { Ponto de } \\
\text { amostragem }\end{array}$ & $\begin{array}{c}\text { ST } \\
\left(\mathbf{g ~ S T} / \mathbf{g}_{\text {suporte }}\right)\end{array}$ & $\begin{array}{c}\text { SVT } \\
\left(\mathbf{g ~ S V T} / \mathbf{g}_{\text {suporte }}\right)\end{array}$ \\
\hline 1 & 0,02 & 0,01 \\
2 & 0,97 & 0,83 \\
3 & 1,14 & 0,91 \\
5 & 0,54 & 0,47 \\
6 & 0,30 & 0,29 \\
\hline
\end{tabular}

Para efeito de comparação com outros sistemas de tratamento que utilizam células em suspensão, estimou-se a concentração de ST e SVT ao longo do leito reacional do reator, conforme apresentado na Tabela 5.12. Para esta estimativa considerou-se a massa específica aparente dos suportes de argila expandida e espuma de poliuretano, respectivamente, $510 \mathrm{~g} / \mathrm{l}$ e $10,5 \mathrm{~g} / \mathrm{l}$.

A maior concentração de biomassa foi observada nos módulos anaeróbios do reator, os quais receberam a maior carga orgânica proveniente da alimentação do sistema. Com a recirculação interna de efluente tratado, estes módulos tornaram-se não apenas anaeróbios, mas também anóxicos, aumentando o coeficiente de produção celular nestas zonas. Com relação aos módulos aeróbios, a baixa carga de matéria orgânica aplicada, remanescente do reator anaeróbio, e o baixo coeficiente de produção celular das bactérias nitrificantes contribuíram para uma menor concentração de biomassa neste módulos.

Tabela 5.12 - Concentrações estimadas de sólidos totais (ST) e sólidos voláteis totais (SVT) no leito do reator combinado anaeróbio-aeróbio vertical de leito fixo.

\begin{tabular}{ccc}
\hline $\begin{array}{c}\text { Ponto de } \\
\text { amostragem }\end{array}$ & $\begin{array}{c}\text { ST } \\
(\text { g ST/l) }\end{array}$ & $\begin{array}{c}\text { SVT } \\
(\text { g SVT/I) }\end{array}$ \\
\hline 1 & 10,7 & 6,0 \\
2 & 10,2 & 8,8 \\
3 & 12,0 & 9,5 \\
5 & 5,6 & 4,9 \\
6 & 3,1 & 3,1 \\
\hline
\end{tabular}




\subsubsection{Número mais provável (NMP) de bactérias no biofilme}

As análises de NMP para bactérias heterótrofas, nitrificantes e desnitrificantes são apresentadas na Tabela 5.13.

Tabela 5.13 - Resultados de NMP de bactérias heterótrofas, nitrificantes e desnitrificantes por grama de sólidos voláteis totais (SVT) aderidos nos suportes.

\begin{tabular}{lcccc}
\hline \multicolumn{1}{c}{ NMP / g SVT } & \multicolumn{5}{c}{ Pontos de amostragem } \\
\cline { 2 - 5 } & $\mathbf{1}$ & $\mathbf{2}$ & $\mathbf{3}$ & $\mathbf{5}$ \\
\hline Heterótrofas & - & - & - & $1,0 \times 10^{13}$ \\
Nitrificantes & & & & \\
$\quad$ Oxidadoras de amônia & - & - & - & $1,0 \times 10^{10}$ \\
$\quad$ Oxidadoras de nitrito & - & - & - & $1,6 \times 10^{8}$ \\
Desnitrificantes & $1,6 \times 10^{10}$ & $1,7 \times 10^{12}$ & $7,9 \times 10^{9}$ & $5,2 \times 10^{9}$ \\
\hline
\end{tabular}

Como era esperado devido aos resultados obtidos nas etapas de operação do sistema, as análises de NMP mostraram a presença de altas concentrações de bactérias desnitrificantes ao longo de todo o reator, inclusive aderidas nos suportes de espuma da zona aeróbia. Estes resultados comprovaram a atividade desnitrificante na zona aeróbia do reator, reforçando as hipóteses de nitrificação e desnitrificação simultâneas discutidas na etapa experimental 2.

As bactérias desnitrificantes, por serem heterótrofas facultativas, se adaptaram bem às condições anaeróbias e aeróbias do reator. Essas bactérias utilizavam preferencialmente o oxigênio como aceptor de elétrons para a respiração celular, mas na ausência deste, utilizavam o nitrato ou nitrito, reduzindo esses compostos a nitrogênio molecular e promovendo a desnitrificação.

Os resultados de NMP de bactérias nitrificantes mostraram um equilíbrio entre as populações de bactérias oxidadoras de amônia e de oxidadoras de nitrito, evidenciando a rota convencional de nitrificação, ou seja, amônia sendo oxidada a nitrito e posteriormente a nitrato.

As bactérias heterótrofas totais também foram encontradas em alta concentração nos módulos aeróbios do reator. 


\subsubsection{Caracterização morfológica do biofilme}

A caracterização morfológica do biofilme anaeróbio por microscopia ótica de contraste de fase e de fluorescência, apresentada na Tabela 5.14 e Figuras 5.54 e 5.55, indicou a predominância de bacilos aderidos em ambos os tipos de suporte, argila expandida e espuma de poliuretano. Entre as bactérias, as morfologias mais freqüentes foram os bacilos com inclusões e curvos (vibriões), sendo observado baixa frequiência de cocos. As morfologias predominantes entre as arquéias metanogênicas foram os bacilos delgados fluorescentes, semelhantes a Methanobacterium sp. e Methanospirillum sp., possivelmente associados a presença de hidrogênio $\left(\mathrm{H}_{2}\right)$ proveniente das etapas anteriores de degradação de matéria orgânica. Com menor freqüência, também foram observados microrganismos semelhantes a Methanosarcina sp. e Methanosaeta sp., associadas possivelmente a presença de acetato no meio.

Tabela 5.14 - Ocorrência das morfologias observadas na zona anaeróbia do reator combinado anaeróbio-aeróbio vertical de leito fixo.

\begin{tabular}{lccc}
\hline \multicolumn{1}{c}{ Morfologia } & \multicolumn{3}{c}{ Ponto de amostragem } \\
\cline { 2 - 4 } & $\mathbf{1}$ & $\mathbf{2}$ & $\mathbf{3}$ \\
\hline Arquéias metanogênicas & & ++ & +++ \\
Methanosarcina sp. & ++ & +++ \\
Methanosaeta sp. & +++ & +++ & ++++ \\
Bacilos fluorescentes & ++++ & ++++ & \\
Bactérias & & & ++++ \\
Bacilos & ++++ & ++++ & ++ \\
Bacilos curvos & +++ & ++ & +++ \\
Bacilos com inclusões & +++ & +++ & + \\
Cocos & ++ & + & - \\
Filamentos & - & - & + \\
\hline (++++) predominante; (+++) freqüente; $(++)$ pouco freqüente; $(+)$ raro; (-) não foi observado
\end{tabular}




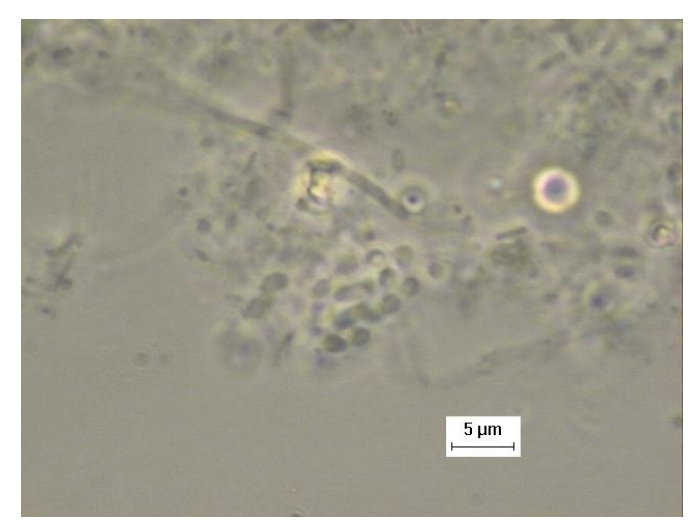

(a) Cocos agrupados

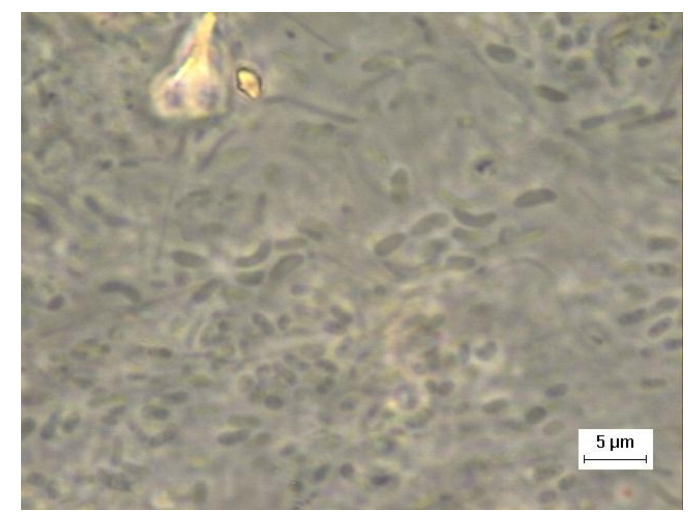

(c) Bacilos curvos

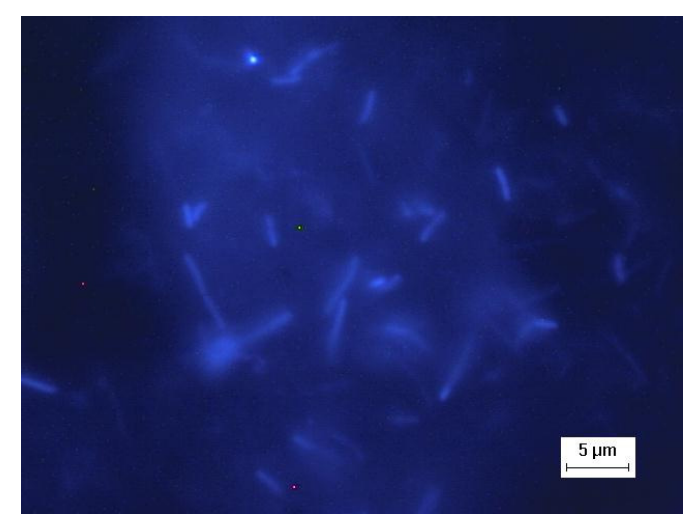

(e) Bacilos fluorescentes

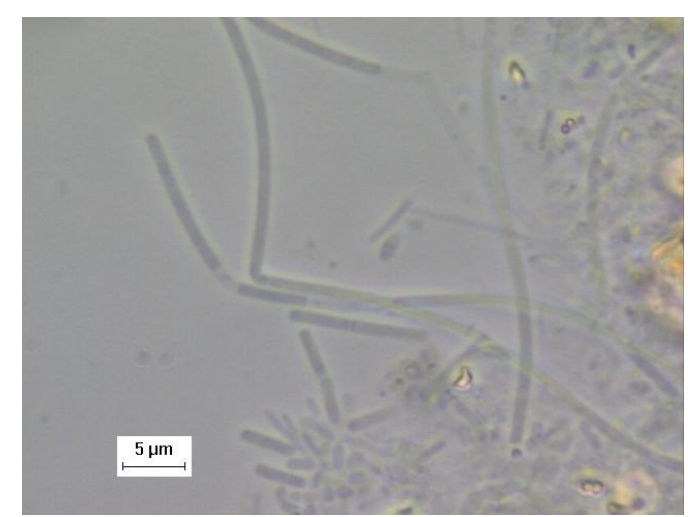

(b) Microrganismos semelhantes à Methanosaeta sp.

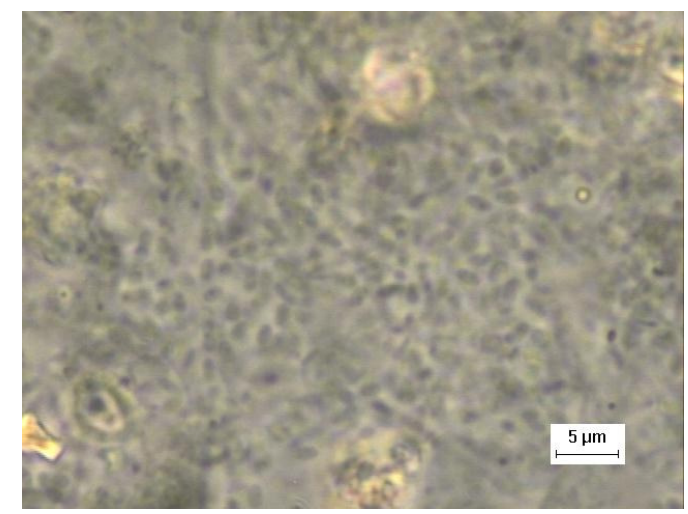

(d) Bacilos com inclusões

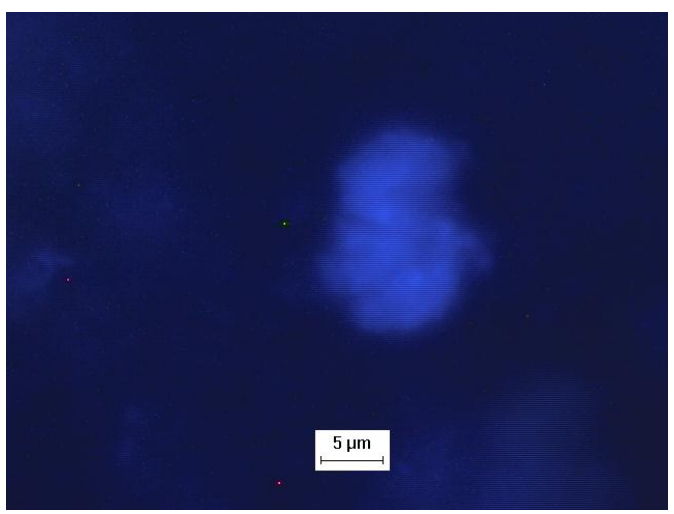

(f) Microrganismos semelhantes à Methanosarcina sp.

Figura 5.54- Observações morfológicas sob microscopia ótica referente à biomassa aderida ao suporte de argila expandida na zona anaeróbia do reator combinado anaeróbio-aeróbio vertical de leito fixo (ponto de amostragem 1) 
Reator combinado anaeróbio-aeróbio de leito fixo para remoção de matéria orgânica e nitrogênio de

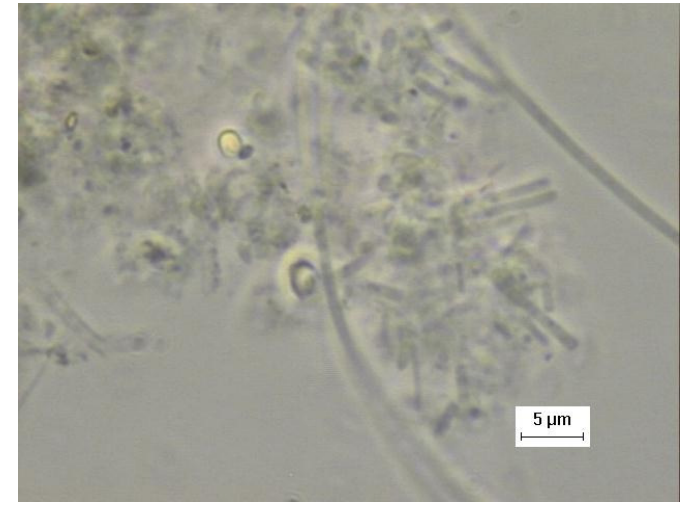

(a) Microrganismos semelhantes à Methanosaeta sp.

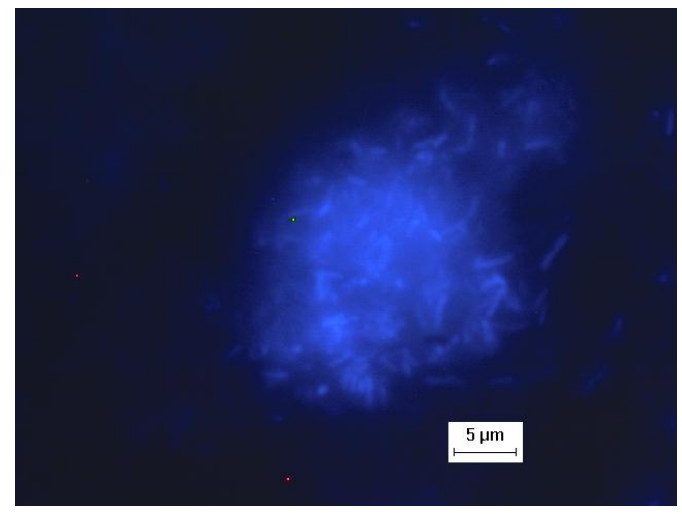

(c) Bacilos fluorescentes

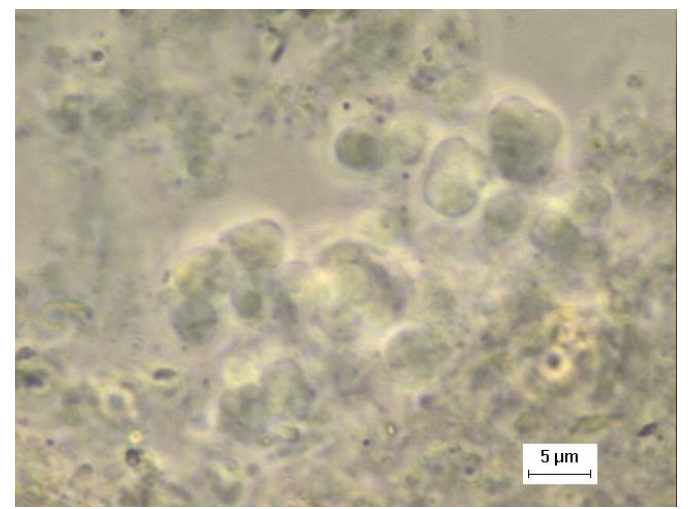

(e) Microrganismos semelhantes à Methanosarcina sp.

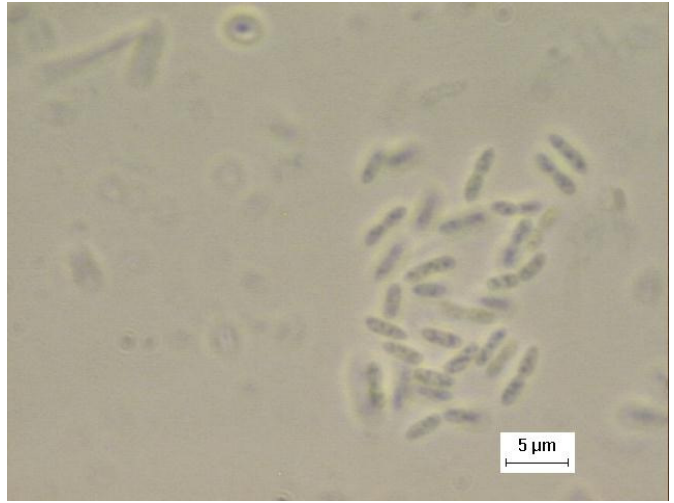

(b) Bacilos com inclusões

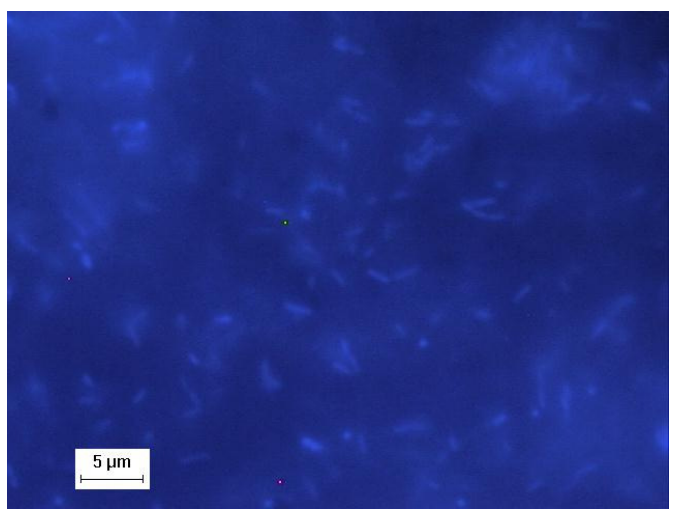

(d) Bacilos fluorescentes

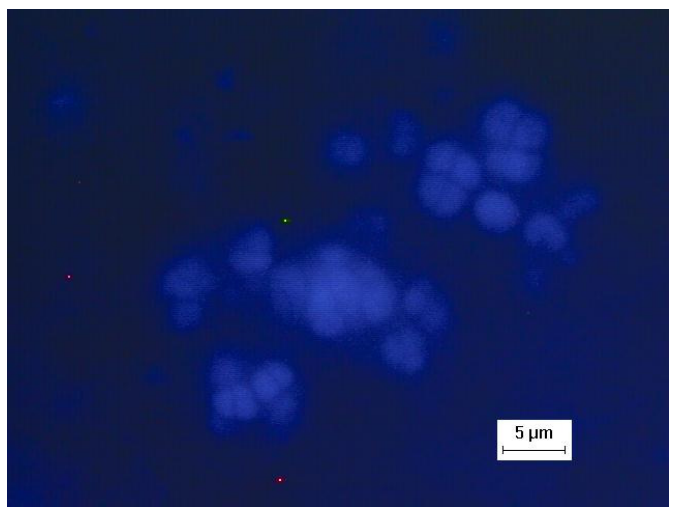

(f) Microrganismos semelhantes à Methanosarcina sp.

Figura 5.55 - Observações morfológicas sob microscopia ótica referente à biomassa aderida aos suportes de espuma de poliuretano na zona anaeróbia do reator combinado anaeróbio-aeróbio vertical de leito fixo (pontos de amostragem 2 e 3 ). 
A caracterização morfológica do biofilme aeróbio por microscopia ótica de contraste de fase é apresentada na Tabela 5.15 e Figuras 5.56 e 5.57. Na amostra de biomassa suspensa coletada na câmara de aeração do reator (ponto de amostragem 4) foi observado altíssima concentração de filamentos, possivelmente associados a falta de suporte para imobilização celular, desfavorecendo o crescimento de outras morfologias. Em baixa frequiência, também foram observados bacilos e protozoários.

Nos suportes de espuma de poliuretano das zonas aeróbias observou-se predominância de bacilos com inclusões, possivelmente associados às atividades heterótrofas e desnitrificantes. Alta freqüência de cocos também foi observada, principalmente cocos agrupados. Com relação a bactérias filamentosas, protozoários e metazoários, foram observadas baixas frequiências destas morfologias.

Tabela 5.15 - Ocorrência das morfologias observadas na zona aeróbia do reator combinado anaeróbio-aeróbio vertical de leito fixo.

\begin{tabular}{lccc}
\hline \multicolumn{1}{c}{ Morfologia } & \multicolumn{3}{c}{ Ponto de amostragem } \\
\cline { 2 - 4 } & $\mathbf{4}$ & $\mathbf{5}$ & $\mathbf{6}$ \\
\hline Bactérias & ++ & +++ & ++++ \\
$\quad$ Bacilos com inclusão & - & +++ & +++ \\
Cocos & ++++ & ++ & ++ \\
Filamentos & & & ++ \\
Protozoários & - & ++ & - \\
$\quad$ Euglypha sp & + & + & ++ \\
$\quad$ Flagelados & ++ & & - \\
$\quad$ Cistos de protozoários & & + & + \\
Metazoários & - & & + \\
$\quad$ Verme nematóide & & & \\
\hline
\end{tabular}




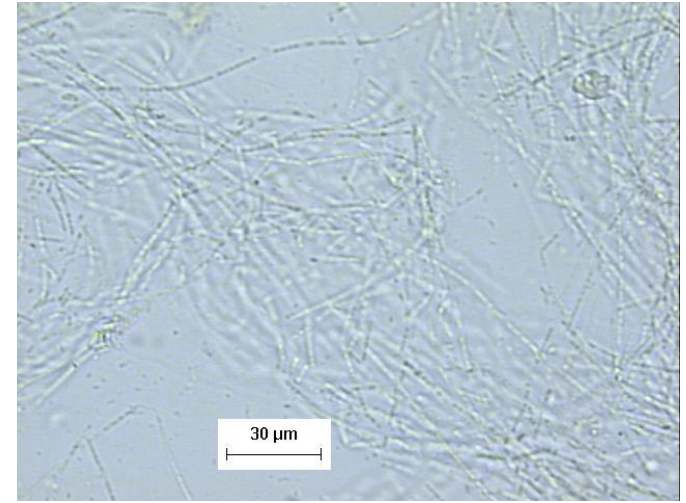

(a) Filamentos

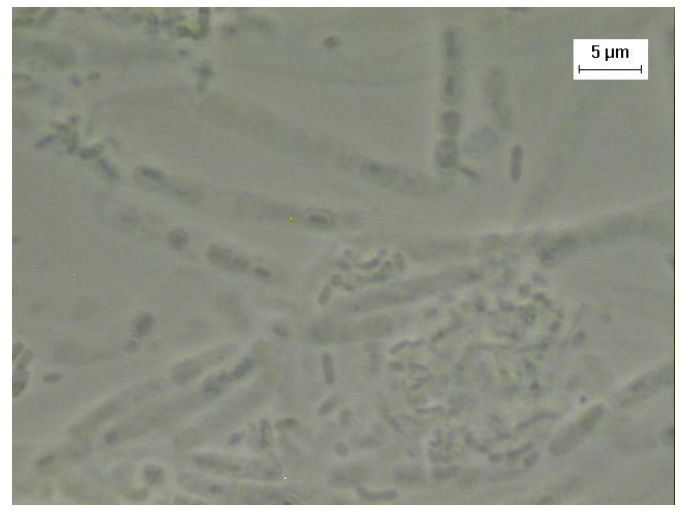

(c) Bacilos

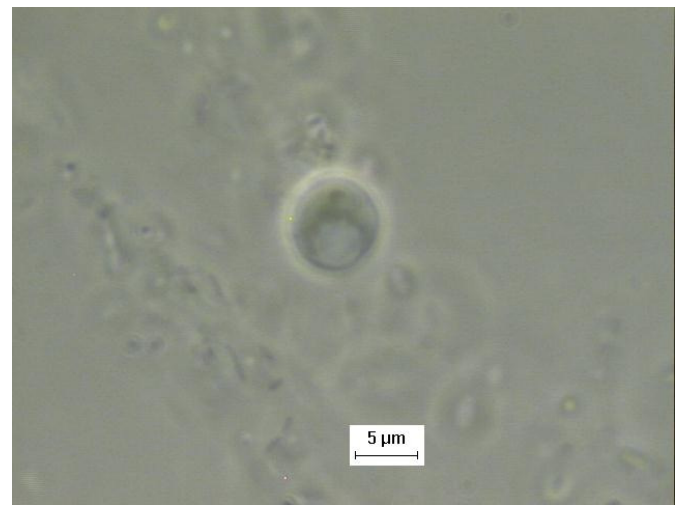

(e) Cisto de protozoário

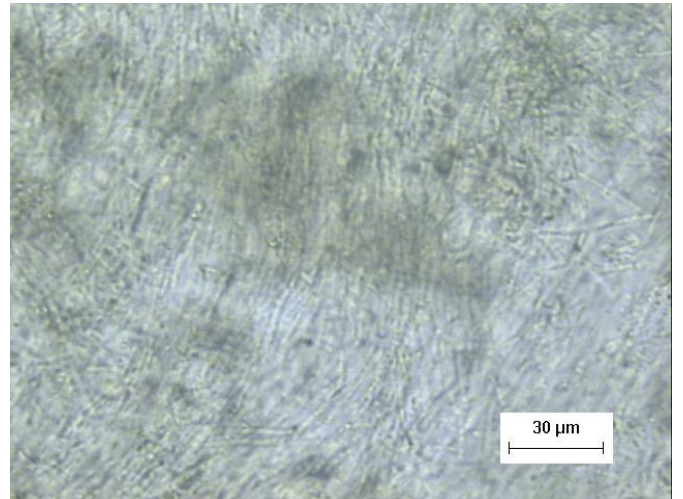

(b) Filamentos

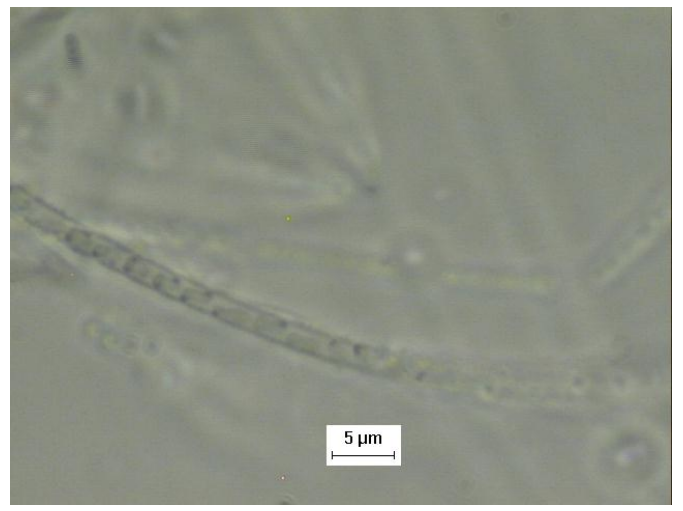

(d) Bactéria filamentosa.

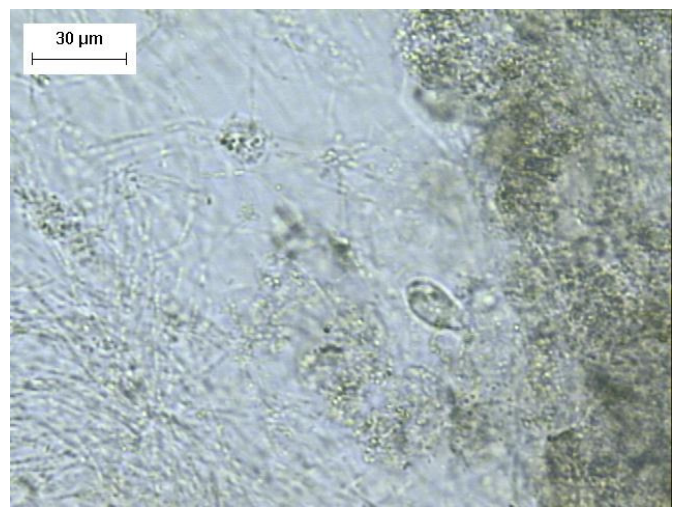

(f) Protozoário

Figura 5.56 - Observações morfológicas sob microscopia ótica referente à biomassa suspensa coletada na interface entre as zonas anaeróbia e aeróbia do reator combinado anaeróbio-aeróbio vertical de leito fixo (ponto de amostragem 4). 


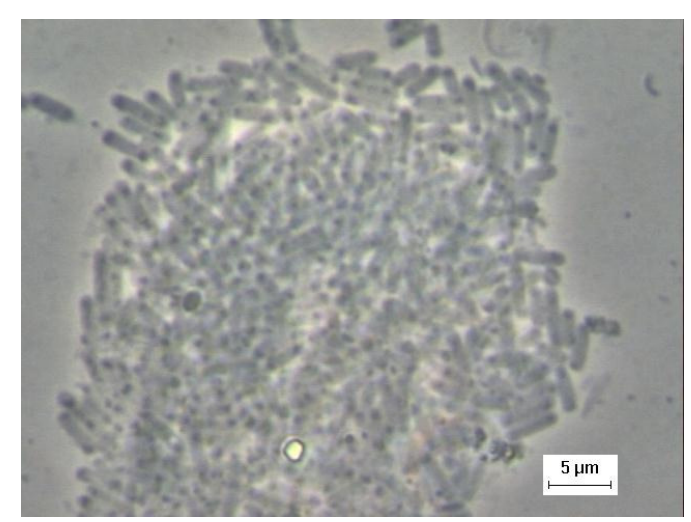

(a) Bacilos com inclusões

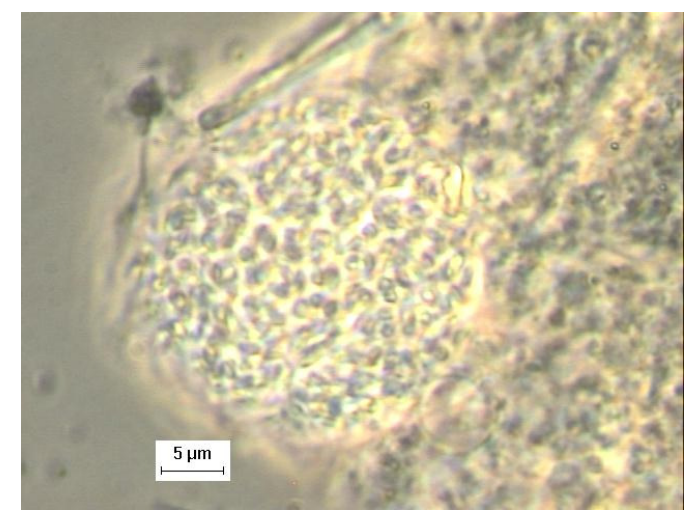

(c) Cocos agrupados

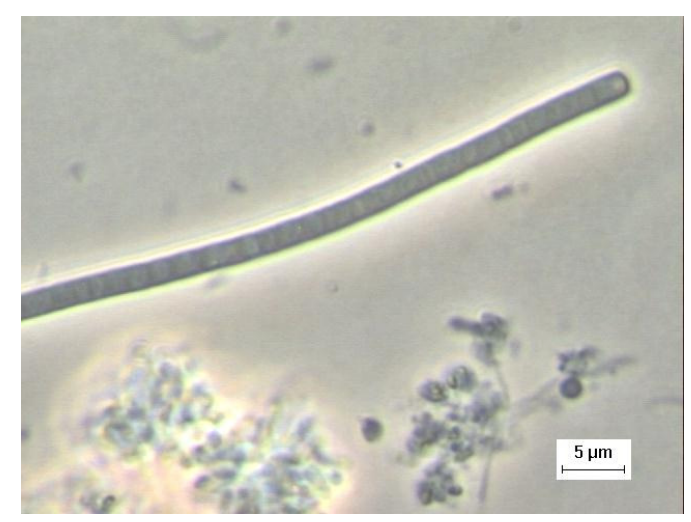

(e) Bactéria filamentosa semelhante ao tipo $021 \mathrm{~N}$

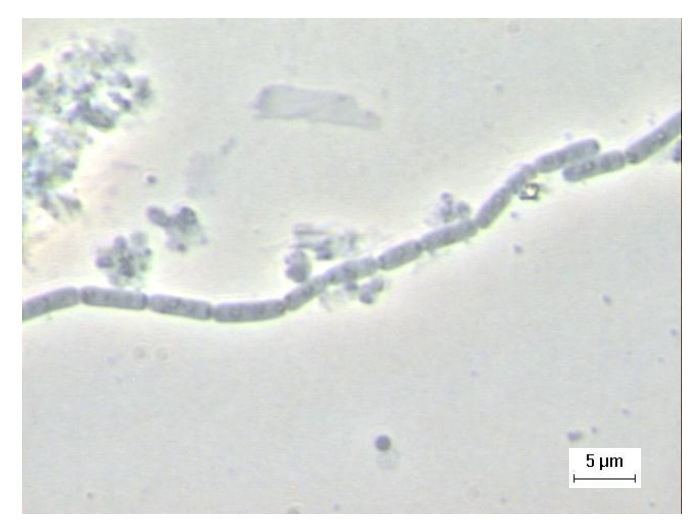

(b) Cadeia de bacilos com inclusões

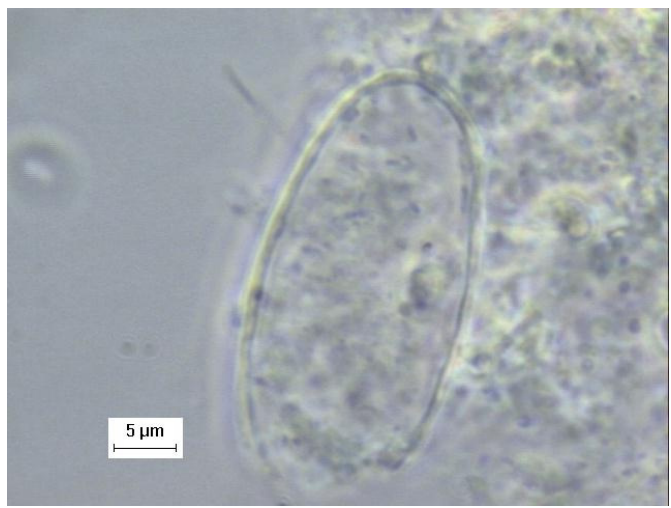

(d) Microrganismo semelhantes à Euglypha sp.

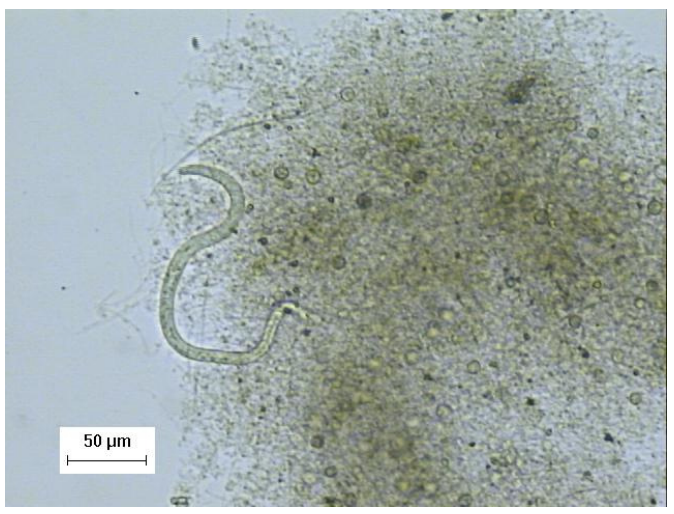

(f) Verme nematóide

Figura 5.57 - Observações morfológicas sob microscopia ótica referente à biomassa aderida aos suportes de espuma de poliuretano na zona aeróbia do reator combinado anaeróbio-aeróbio vertical de leito fixo (pontos de amostragem 5 e 6). 


\subsection{CONSIDERAÇÕES SOBRE A OPERACIONALIDADE DO REATOR}

Ao longo da operação do reator combinado anaeróbio-aeróbio vertical de leito fixo observou-se uma gradativa colmatação de seu leito reacional devido ao crescimento da biomassa imobilizada nos suportes, fazendo com que a distribuição hidráulica no reator ficasse prejudicada. Os módulos que apresentaram maior obstrução foram os módulos anaeróbios com espuma de poliuretano, principalmente após o início da operação com recirculação de efluente tratado devido ao maior crescimento da biomassa heterótrofa desnitrificante.

A espuma de poliuretano, por ser um material altamente compressível, também contribuiu significativamente para a colmatação do leito do reator, chegando a fechar a seção transversal do reator quando as pressões internas se elevavam devido à incrustação de sólidos nos interstícios dos suportes.

Para solucionar o problema, quando o reator apresentava alta perda de carga, observada pela diminuição da vazão efluente ao reator, aplicava-se um descarte de fundo no reator fazendo com que houvesse um fluxo contrário ao escoamento normal, rearranjando o material suporte e desobstruindo, embora momentaneamente, o leito do reator.

Com relação ao leito de argila expandida, houve grande crescimento de biomassa em seus interstícios, contudo, não foi observado nenhum sinal de colmatação, mantendo boa distribuição hidráulica durante toda a operação do reator. 



\section{Conclusões}

O principal resultado deste trabalho foi a constatação da viabilidade técnica da aplicação do reator combinado anaeróbio-aeróbio vertical de leito fixo como única unidade de tratamento para água residuária industrial contendo altas concentrações de matéria orgânica e nitrogênio.

O reator combinado anaeróbio-aeróbio vertical de leito fixo se mostra promissor para o tratamento de águas residuárias industriais com altas concentrações de matéria orgânica e nitrogênio, tendo algumas vantagens sobre os sistemas convencionais de tratamento por lodos ativados, tais como, menor área de implantação, pequena geração de lodo e simplicidade operacional. Entretanto, a limitação para o aumento de escala do reator está relacionada a escolha de um material suporte não compressível, fazendo com que o leito do reator seja menos susceptível à colmatação.

A melhor condição operacional do reator foi conseguida aplicando-se tempo de detenção hidráulica (TDH) de 35 h, com base no volume útil do reator, e razão de recirculação $(\mathrm{R})$ igual a 3,5, apresentado eficiências na remoção de DQO, NTK e NT de 97\%, 96\% e 77\%, respectivamente, com concentrações efluentes de $36 \pm 10 \mathrm{mg}$ DQO/l, $2 \pm 1 \mathrm{mg} \mathrm{N}-\mathrm{NH}_{4}{ }^{+} / 1,8 \pm 3 \mathrm{mg} \mathrm{N}-\mathrm{org} / \mathrm{l}, 1 \pm 1 \mathrm{mg} \mathrm{N}-\mathrm{NO}_{2}{ }^{-} / \mathrm{l}$ e $26 \pm 23 \mathrm{mg} \mathrm{N}^{-N_{3}}{ }_{3}^{-} / 1$

Em relação aos resultados específicos do trabalho, foi possível tirar as seguintes conclusões:

- O melhor desempenho do reator anaeróbio vertical de leito fixo foi alcançado na operação com tempo de detenção hidráulica de 21 h, com base no volume útil do reator, apresentando eficiências médias na remoção de DQO e SST de $70 \pm 6 \%$ e $70 \pm 13 \%$, 
respectivamente. Com uma carga orgânica volumétrica aplicada (COV) de 3,4 kg DQO. $\mathrm{m}^{-3} \cdot \mathrm{d}^{-1}$ e concentração média afluente de $1396 \pm 153 \mathrm{mg}$ DQO/l, obteve-se efluente tratado com concentração média de $261 \pm 56$ mg DQO/l.

- A aeração aplicada no topo do reator anaeróbio vertical de leito fixo durante a etapa experimental 3, provocou um aumento de $16 \%$ na eficiência média de remoção de DQO do reator, passando de $70 \pm 6 \%$ para $86 \pm 2 \%$, respectivamente, antes e depois da aplicação da aeração. Os possíveis processos envolvidos neste fenômeno são a oxidação química e/ou biológica da matéria orgânica remanescente e a oxidação de compostos reduzidos de enxofre formados no reator anaeróbio. A aeração no topo do reator anaeróbio vertical de leito fixo também favoreceu, embora de forma não controlada, o crescimento de organismos nitrificantes neste reator, fazendo com que houvesse um aumento nas concentrações de N-nitrito e N-nitrato no seu efluente. Portanto, o topo do reator funcionava como um reator aeróbio (ou reator químico) sem suporte para a imobilização celular, operando com baixo tempo de detenção hidráulica.

- O fenômeno de nitrificação e desnitrificação simultâneas observado nos módulos aeróbios do reator combinado anaeróbio-aeróbio vertical de leito fixo durante a segunda etapa experimental mostrou que o nitrogênio afluente pode ser removido em uma única etapa de tratamento, não necessitando de sistemas de pós-tratamento ou recirculação do efluente tratado em reatores desnitrificantes (anóxicos ou anaeróbios). Contudo, a dificuldade de controle da atividade desnitrificante em ambiente aeróbio, onde é processada a nitrificação, ainda é o principal limitante para a implantação deste processo.

- Com a separação das zonas anaeróbia e aeróbia em dois reatores distintos operados em série (etapa 3), a eficiência de remoção de nitrogênio total (NT) do sistema diminuiu, passando de $61 \pm 13 \%$ para $17 \pm 10 \%$, respectivamente antes (etapa 2) e depois (etapa 3) da separação dos módulos. A principal hipótese levantada para explicar o fenômeno relaciona-se à possibilidade dos gases gerados no reator anaeróbio, principalmente $\mathrm{CH}_{4}$ e $\mathrm{H}_{2} \mathrm{~S}$, serem utilizados como doadores de elétrons para a redução do nitrato a nitrogênio gasoso no reator aeróbio. 
- Os valores de eficiência de desnitrificação $\left(\mathrm{E}_{\mathrm{DN}}\right)$ experimentais, obtidos na operação do reator combinado anaeróbio-aeróbio vertical de leito fixo variando-se a razão de recirculação, apresentaram grande correlação com os valores teóricos calculados. Portanto, pôde-se concluir que o sistema obteve as eficiências máximas de desnitrificação previstas para cada vazão de recirculação aplicada, sendo elas 33\%, 50\% e $78 \%$, respectivamente para razões de recirculação iguais a $0,5,1$ e 3,5.

- As análises de NMP mostraram a presença de altas concentrações de bactérias desnitrificantes ao longo de todo o reator, inclusive aderidas nos suportes de espuma da zona aeróbia. Estes resultados comprovaram a atividade desnitrificante na zona aeróbia do reator, reforçando a hipótese de ocorrência de nitrificação e desnitrificação simultâneas durante a operação do reator combinado anaeróbio-aeróbio vertical de leito fixo na segunda etapa experimental.

- Os resultados de NMP de bactérias nitrificantes da zona aeróbia do reator combinado anaeróbio-aeróbio vertical de leito fixo mostraram um equilíbrio entre as populações de bactérias oxidadoras de amônia e de oxidadoras de nitrito, evidenciando a rota convencional de nitrificação, ou seja, amônia sendo oxidada a nitrito e posteriormente a nitrato. 



\section{SugEstões}

A partir dos resultados obtidos neste trabalho, propõem-se as seguem sugestões para o aprimoramento de reatores combinados anaeróbio-aeróbio verticais de leito fixo:

- Estudar novos suportes para imobilização celular que não sofram compressão durante a operação do reator, fazendo com que o leito reacional apresente menos problemas de entupimento;

- Investigar estratégias de limpeza do leito reacional fixo do reator visando a remoção do excesso de biomassa formado durante a operação;

- Aumentar a escala do reator combinado anaeróbio-aeróbio vertical de leito fixo e estudar a distribuição hidrodinâmica do sistema;

- Investigar o desempenho do reator combinado anaeróbio aeróbio vertical de leito fixo tratando outros tipos de água residuária. 



\section{Referências Bibliográficas}

AISSE, M.M.; NOLASCO, M.A., ANDREOLI, F.D.N.; LOBATO, M.B.; SAVELLI, C.S.; JURGENSEN, D.; ALEM SOBRINHO, P. (2000). Pós-tratamento de efluentes provenientes de reatores anaeróbios tipo UASB. Proc. VI Latin-American Workshop and Seminar on Anaerobic Digestion. Recife, Brasil, 321-327.

AJINOMOTO (2006). Relatório de operação da estação de tratamento de efluentes da fábrica da Ajinomoto situada em Valparaíso, SP.

ALEXANDER, M. (1984). Most probable number method for microbial populations. In: Methods of soil analysis - Chemical and microbiological properties, $\mathrm{n}^{\circ} 9$, part 2. $2^{\text {nd }}$ edition. p815-829. Wisconsin, Estados Unidos.

ALVES, M.M. (1999). A new device to select microcarries for biomass immobilization to an anaerobic consortium. Water Environment Research, 71(2): 209-217.

ANTHONISEN, A. C., LOEHR, R. C., PRAKASAM, T. B. S. SRINATH, E. G. (1976). Inhibition of nitrification by ammonia and nitrous acid. Journal WPCF, 48(5): 835-852.

BRYERS, J.D. \& CHARACKLIS, W.G. (1990). Biofilms in water and wastewater treatment. In: CHARACKLIS, W.G., MARSHALL, K.C.(Editors). Biofilms. John Wiley \& Sons, Inc. U.S.A.: 671- 696. 
CALLADO, N.H. \& FORESTI, E. (2001). Removal of organic carbon, nitrogen and phosphorus in sequential batch reactors integrating the anaerobic/aerobic processes. Water Science \& Technology, 44(4): 263-270.

CALLADO, N.H. (2001). Reatores seqüenciais em batelada em sistema anaeróbio/aeróbio tratando esgoto sanitário sintético. Tese de Doutorado. Escola de Engenharia de São Carlos, Universidade de São Paulo.

CARRERA, J.; BAEZA, J.A.; VICENT, T.; LAFUENTE, J. (2003). Biological nitrogen removal of high-strength ammonium industrial wastewater with two-sludge system. Water Research, 37: 4211-4221.

CARRERA, J.; VICENT, T.; LAFUENTE, J. (2004). Effect of influent COD/N ratio on biological nitrogen removal (BNR) from high-strength ammonium industrial wastewater. Process Biochemistry, 39: 2035-2041.

CHEN, T.K.; NI, C.H.; CHEN, J.N. (2003a). Biological nitrification and denitrification of epto-eletronic industrial wastewater. Water Science and Technology, 48(8): 2734.

CHEN, T.K.; NI, C.H.; CHEN, J.N; LIN, J. (2003b). High-strength nitrogen removal of epto-eletronic industrial wastewater in membrane bioreactor - a pilot study. Water Science and Technology, 48(1): 191-198.

CHERNICHARO C.A.L. (2006). Post-treatment opitions for the anaerobic treatment of domestic wastewater. Reviews in Environmental Science and Bio/Technology, 5:73-92.

CHERNICHARO, C.A.L. \& NASCIMENTO, M.C.P. (2001). Feasibility of a pilotscale UASB/trickling filter system for domestic sewage treatment. Water Science \& Technology, 44(4): 221-228.

CHERNICHARO, C.A.L.(2001).Coordenador. Pós-tratamento de efluentes de reatores anaeróbios. PROSAB.544p. Belo Horizonte. 
CHUI, P. C.; TERASHIMA, Y.; TAY, J. H.; OZAKI, H. (1996). Performance of a partly aerated biofilter in the removal of nitrogen. Water Science and Technology, 34(1): $187-194$.

COLLIVER, B.B. \& STEPHENSON, T. (2000). Production of nitrogen oxide and dinitrogen oxide by autotrophic nitrifiers. Biotechnology Advances, 18: 219-232.

CUBA, R.M.F. (2005). Avaliação do potencial de uso do metano como doador de elétrons para a desnitrificação em reator anóxico horizontal de leito fixo. Dissertação de Mestrado. Escola de Engenharia de São Carlos, Universidade de São Paulo.

DANIEL, L.M.C. (2005). Remoção de nitrogênio via nitrito em reator em batelada seqüencial contendo biomassa imobilizada e aeração intermitente. Tese de Doutorado. Escola de Engenharia de São Carlos, Universidade de São Paulo.

DILALLO, R.; ALBERTSON, O.E. (1961). Volatile acids by direct titriation. Journal Water Pollution Control Federation, 31(10): 2495-2499.

FORESTI, E ; ZAIAT, M.; VALLERO, M. (2006). Anaerobic processes as the core technology for sustainable domestic wastewater treatment: Consolidated applications, new trends, perspectives, and challenges. Reviews in Environmental Science and Bio/Technology, 5:3-19.

GIJZEN, H.J.; SCHOENMAKERS, T.J.M.; CAERTELING, C.G.M.; VOGELS, G.D. (1988). Anaerobic degradation of papermill sludge in a two-phase digester containing rumen microorganisms and colonized polyurethane foam. Biotechnology Letters, 10(1): 61-66.

GONÇALVES, R.F.; PASSAMANI, F.R.F.;SALIM, F.P.; SILVA, A.L.B.; MARTINELI, G.; BAUER D.G (2000). Associação de um reator UASB e biofiltros aerados submersos para tratamento de esgoto sanitário. Pós tratamento de efluentes de reatores anaeróbios - Coletânea de Artigos Técnicos, 1:119-134, FINEP/PROSAB. 
HAGOPIAN, D.S. \& RILEY, J.G. (1998). A closer look at the bacteriology of nitrification. Aquacultural Engineering, 18: 223-244.

HUYSMAN, P.; VAN MEENEN, P.; VAN ASSCHE, P.; VERSTRAETE, W.(1983). Factors affecting colonization of nonporous packing materials in model upflow methane reactors. Biotechnology Letters, 5: 643-648.

KHIN, T. \& ANNACHHATRE, A.P. (2004). Novel microbial nitrogen removal processes. Biotechnology Advances, 22: 519-532.

KUAI, L. \& VERSTRAETE, W. (1998). Ammonium removal by the oxygen-limited autotrophic nitrification-denitrification system. Applied and Environmental Microbiology, 64(11): 4500-4506.

LACALLE, M.L.; VILLAVERDE, S.; FDZ-POLANCO, F.; GARCÍA-ENCINA, P.A. (2001). Combined anaerobic/aerobic (UASB+UBAF) system for organic matter and nitrogen removal from a high strength industrial wastewater. Water Science and Technology, 44(4): 255-262.

LEENEN, E.J.T.M.; van BOXTEL, A.M.G.A.; ENGLUND，G.; TRAMPER，J.; WIJFFELS, R.H. (1997). Reduced temperture sensitivity of immobilized Nitrobacter agilis cells caused by diffusion limitation. Enzyme and Microbial Technology, 20: 573-580.

MADIGAN, M.T.; MARTINKO, J.M.; PARKER, J. (1997). Brock Biology of Microorganisms, $8^{\text {th }}$ edition. Englewood Cliffs, NJ: Pretice Hall.

MENDONÇA, L.C. (2002). Microbiologia e cinética de sistema de lodos ativados como pós-tratamento de efluente de reator anaeróbio de leito expandido. Tese de Doutorado. Escola de Engenharia de São Carlos, Universidade de São Paulo.

METCALF \& EDDY, Inc. (2003). Wastewater Engineering: Treatment and Reuse. McGraw Hill, $4^{\text {th }}$ edition, 1819p. 
PONTES, P.P.; CHERNICHARO, C.A.L.; FRADE, E.C.; PORTO, M.T.R. (2003). Performance evaluation of na UASB reactor used for combined treatment of domestic sewage and excess aerobic sludge from a trickling filter. Water Science \& Technology, 48(6): 227-234.

RATUSZNEI S.M.; RODRIGUES, J.A.D.; CAMARGO, E.F.M.; ZAIAT, M.; BORZANI, W. (2000). Feasibility of a stirred anaerobic sequencing batch reactor containing immobilized biomass for wastewater treatment. Bioresource Technology, 75(2): 127-132.

RIPLEY, L.E.; BOYLE, W.C.; CONVERSE, J.C. (1986). Improved alkalinimetric monitoring for anaerobic digestion of high-strength wastes. Journal Water Polution Control Federation, 58: 406-411.

ROS, M. \& VRTOVSEK, J. (1998). Wastewater treatment and nutrient removal in the combined reactor. Water Science and Technology, 38(1): 87-95.

SANTOS, S.G.; VARESCHE, M.B.A.; ZAIAT, M.; FORESTI, E. (2004). Comparison of methanol, ethanol, and methane as electron donors for denitrification. Environmental Engineering Science, 21(3): 313-320.

SCHMIDT, I.; SLIEKERS, O.; SCHMID, M.; BOCK, E.; FUERST, J.; KUENEN, J.G.; JETTEN, M.S.M.; STROUS, M. (2003). New concepts of microbial treatment processes for the nitrogen removalin wastewater. FEMS Microbiology Reviews, 27: 481-492.

SCHMIDT, I.; SLIEKERS, O.; SCHMID, M.; IRINA, C.; STROUS, M; BOCK, E.; KUENEN, J.G.; JETTEN, M.S.M.; (2002). Aerobic and anaerobic ammonia oxidizing bacteria - competitors or natural partners? FEMS Microbiology Reviews, 39: $175-181$.

SCHMIDT, E.L. \& BELSER, L.W. (1984). Nitrifying bacteria. In: Methods of soil analysis - Chemical and microbiological properties, $n^{\circ}$, part 2. $2^{\text {nd }}$ edition. P10271042. Wisconsin, Estados Unidos. 
Standard Methods for the Examination of Water and Wastewater (1998). 20 $0^{\text {th }}$ edition. American Public Health Association / American Water Works Association / Water Environment Federation. Washington D.C.

TIEDJE, J. (1984). Denitrification. In: Methods of soil analysis - Chemical and microbiological properties, $\mathrm{n}^{\mathrm{o}} 9$, part 2. $2^{\text {nd }}$ edition. P1011-1026. Wisconsin, Estados Unidos.

van HAANDEL, A.C.; MARAIS, G. (1999). O comportamento do sistema de lodos ativados - Teoria e aplicações para projetos e operação. Epgraf, 472p.

VARESCHE, M.B.; ZAIAT, M.; VIEIRA, L.G.T.; VAZOLLER, R.F.; FORESTI, E. (1997). Microbial colonization of polyurethane foam matrices in horizontal-flow anaerobic immobilized-sludge reactor. Applied Microbiology Biotechnology, 48: 534-538.

VILLAVERDE, S.; GARCÍA-ENCINA, P.A.; LACALLE, M.L.; FDZ-POLANCO, F. (2000). New operational strategy for SBR technology for total nitrogen removal from industrial wastewater highly loaded with nitrogen. Water Science and Technology, 41(12): 85-93.

WIRTZ, R.A. \& DAGUE, R.R. (1997). Laboratory studies on enhancement of granulation in the anaerobic sequencing batch reactor. Water Science Technology, 36: $279-286$. 